\title{
ANL/ES-161 \\ MILDOS-AREA: AN ENHANCED VERSION OF MILDOS FOR LARGE-AREA SOURCES
}

ANL/ES- -161

DE89 014334

\author{
by \\ Y.C. Yuan,* J.H.C. Wang, ${ }^{\ddagger}$ and A. Zielen \\ Energy and Environmental Systems Division
}

June 1989

work sponsored by

U.S. DEPARTMENT OF ENERGY

Oak Ridge Operations Office

Oak Ridge, Tennessee

*Current address: Dames \& Moore, Orchard Park, N.Y.

${ }^{\ddagger}$ Current address: Atomic Energy Council, Taipei, Taiwan. 


\section{FOREWORD}

The computer program MILDOS-AREA is a revision of the MILDOS code developed by the Pacific Northwest Laboratory from the Argonne National Laboratory Uranium Dispersion and Dosimetry (UDAD) code. MILDOS was designed to compute environmental radiation doses from uranium recovery operations. The MILDOS-AREA code provides improved capability for handling large-area sources and updates the dosimetry calculations of the original MILDOS code. The new code is designed for use on an IBM or IB.M-compatible parsonal computer. An interim version, MILDOS-ANL, that has been available on a limited basis includes only some of the changes found in the current version of MILDOS-AREA.

This computer software has been developed under sponsorship of the Department of Energy. Any further distribution by any holder of this sof tware package or other data therein outside of DOE offices or other DOE contractors, unless otherwise specifically provided for, is prohibited without the approval of the National Energy Software Center. Requests from outside the Department of Energy for DOE-developed computer software shall be directed to the Director, National Energy Software Center, Argonne National Laboratory, 9700 South Cass Avenue, Argonne, Illinois 60439. The MILDOSAREA program is available on MS-DOS diskettes from the National Energy Sof tware Center. 


\section{CONTENTS}

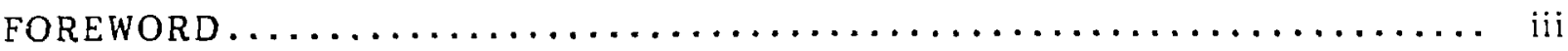

ACKNOWLEDGMENTS $\ldots \ldots \ldots \ldots \ldots \ldots \ldots \ldots \ldots \ldots \ldots \ldots \ldots \ldots \ldots \ldots$ viii

ABSTRACT $\ldots \ldots \ldots \ldots \ldots \ldots \ldots \ldots \ldots \ldots \ldots \ldots \ldots \ldots \ldots \ldots \ldots \ldots \ldots \ldots \ldots \ldots$

$1 \quad$ INTRODUCTION $\ldots \ldots \ldots \ldots \ldots \ldots \ldots \ldots \ldots \ldots \ldots \ldots \ldots \ldots \ldots \ldots \ldots \ldots \ldots \ldots$

2 THEORETICAL BACKGROUND FOR PROGRA M MODIFICATIONS ......... 3

2.1 Atmospheric Dispersion from Area Sources ................... 3

2.2 Vertical-Dispersion Coefficients for Ground-Level Sources . . . . . . . . . . . 10

2.3 Plume Reflection ............................... 10

2.4 Decrease in Source Strength due to Dry Deposition $\ldots \ldots \ldots \ldots \ldots \ldots \ldots \ldots \ldots 12$

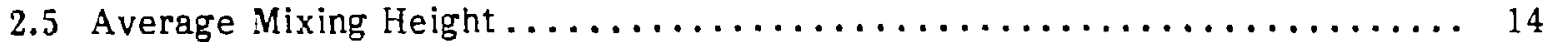

2.6 Internal Dose Conversion Factors ...................... 14

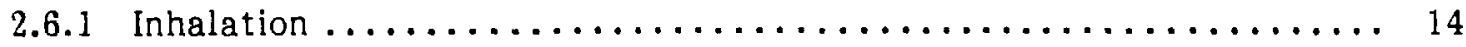

2.6 .2 Age Correction ........................... 15

3 PROGRAM VALIDATION AND OTHER CONSIDERATIONS ............ 24

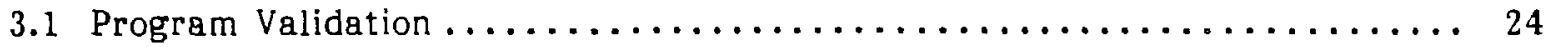

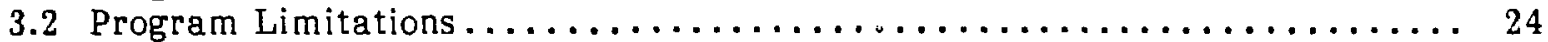

3.3 Accuracy and Performance of MILDOS-AREA ................. 24

3.3.1 Accuracy and Efficiency of Finite-Element Computations ........ 24

3.3.2 Personal Computer Performance .................... 25

3.4 Data Constants ............................... 26

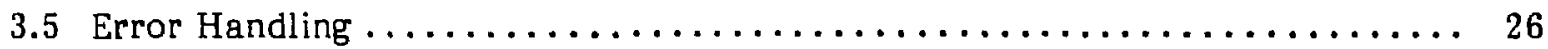

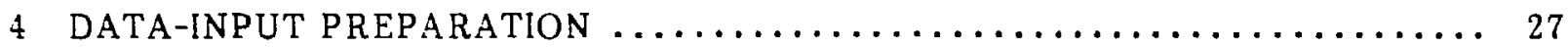

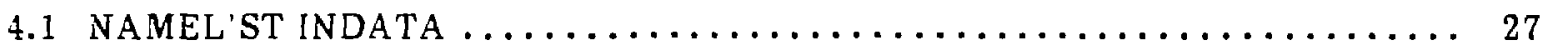

4.1 .1 jab-Control Parameters ........................ 28

4.1 .2 Sourzo-Term Parameters ........................ 28

4.1 .3 Meteorological Parameters ....................... 28

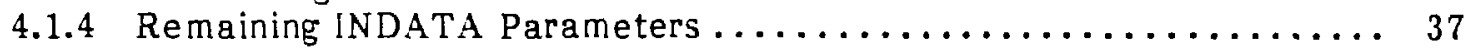

4.2 Title Cards .................................. 37

4.3 NAMELIST NWAREA $\ldots \ldots \ldots \ldots \ldots \ldots \ldots \ldots \ldots \ldots \ldots \ldots \ldots \ldots \ldots \ldots \ldots$

5 INSTALLATION AND USE OF MILDOS-AREA $\ldots \ldots \ldots \ldots \ldots \ldots \ldots \ldots \ldots \ldots$

5.1 Installing MILDOS-AREA $\ldots \ldots \ldots \ldots \ldots \ldots \ldots \ldots \ldots \ldots \ldots \ldots \ldots \ldots \ldots \ldots \ldots \ldots$

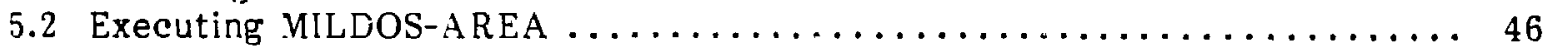

5.3 Viewing Output $\ldots \ldots \ldots \ldots \ldots \ldots \ldots \ldots \ldots \ldots \ldots \ldots \ldots \ldots \ldots \ldots \ldots \ldots$

5.4 Producing Hard Copy and Saving Selected Output .............. 48

$6 \quad$ REFERENCES $\ldots \ldots \ldots \ldots \ldots \ldots \ldots \ldots \ldots \ldots \ldots \ldots \ldots \ldots \ldots \ldots \ldots \ldots \ldots$

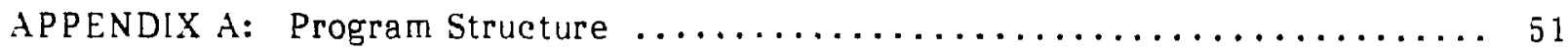




\section{CONTENTS (Cont'd)}

APPENDIX B: Validation of MLLDOS-AREA and Comparison with AIRDOS-EPA $\ldots \ldots \ldots \ldots \ldots \ldots \ldots \ldots \ldots \ldots \ldots \ldots \ldots \ldots \ldots \ldots$

APPENDIX $C:$ Sample Problems and Output $\ldots \ldots \ldots \ldots \ldots \ldots \ldots \ldots \ldots \ldots \ldots$

\section{FIGURES}

2.1 [soparametric Transformation from a Quadrilateral to a Rectangle......... 6

2.2 Annulus/Sector Reference Area for a Given Point Relative to a

Point Source of Unit Strength at Point $(0,0) \ldots \ldots \ldots \ldots \ldots \ldots \ldots \ldots \ldots \ldots$

2.3 Automatic Meshing of a Large Quadrilateral Area ................. 9

4.1 Population-Dose Grid-System Definition ..................... 31

4.2 Geographical Locations of Reference Radon-Release Sites for Continental

Population Doses ................................ 36

4.3 Node Numbering for Quadrilateral Elements . . . . . . . . . . . . . . . . 44

A.1 Hierarchy Diagram of New and Modified Modules . . . . . . . . . . . . . 54

C.1 Schematic Diagram of Hypothetical Situation for SAMPLE.DAT Problem .... 71

C.2 Spatial Orientation of Sources and Receptors for TESTC1.DAT and

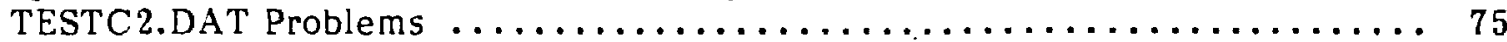

\section{TABLES}

2.1 Values of Constants Used to Estimate Martin-Tickvart

Vertical-Dispersion Coefficients ....................... 11

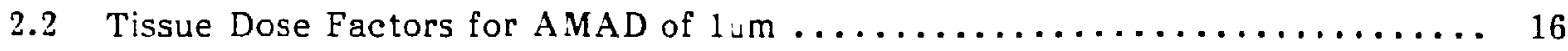

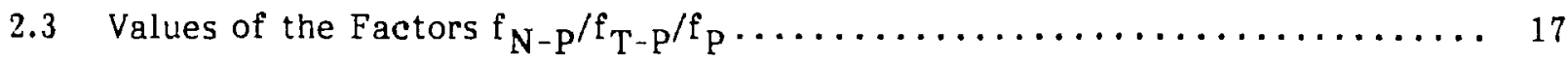

2.4 Inhalation Effective Dose Equivalent Factors $\ldots \ldots \ldots \ldots \ldots \ldots \ldots \ldots$

2.5 Relative Age-Specific Dose Factors from Ingestion $\ldots \ldots \ldots \ldots \ldots \ldots \ldots$

2.6 Relative Age-Specific Dose Factors from Inhalation . . . . . . . . . . ... 20

3.1 Accuracy of Calculated Air Concentrations of a Radionuclide from a

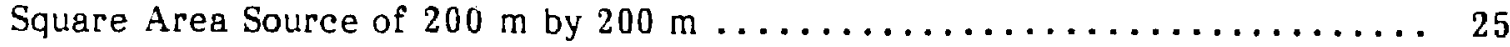

3.2 MLLOS-AREA Execution Times $\ldots \ldots \ldots \ldots \ldots \ldots \ldots \ldots \ldots \ldots \ldots \ldots$ 


\section{TABLES (Cont'd)}

4.1 Classification of MILDOS-AREA Parameters Provided through

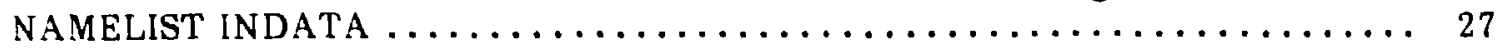

4.2 Job-Control Parameters............................ 29

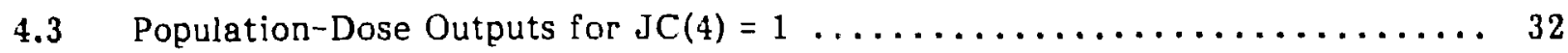

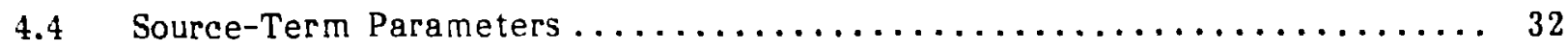

4.5 AMAD Distribution-Set Characteristics $\ldots \ldots \ldots \ldots \ldots \ldots \ldots \ldots \ldots \ldots \ldots$

4.6 Meteorological Parameters $\ldots \ldots \ldots \ldots \ldots \ldots \ldots \ldots \ldots \ldots \ldots \ldots \ldots \ldots \ldots \ldots \ldots \ldots \ldots$

4.7 Food-Pathway Parameters $\ldots \ldots \ldots \ldots \ldots \ldots \ldots \ldots \ldots \ldots \ldots \ldots \ldots \ldots \ldots \ldots \ldots \ldots$

4.8 Average Annual Agricultural Production by State $\ldots \ldots \ldots \ldots \ldots \ldots \ldots \ldots, 39$

4.9 Population-Distribution Parameters $\ldots \ldots \ldots \ldots \ldots \ldots \ldots \ldots \ldots \ldots \ldots \ldots \ldots \ldots$

4.10 Projected Population of the United States, $1980-2050 \ldots \ldots \ldots \ldots \ldots \ldots \ldots 41$

4.11 Individual Receptor-Location Parameters $\ldots \ldots \ldots \ldots \ldots \ldots \ldots \ldots \ldots \ldots, 42$

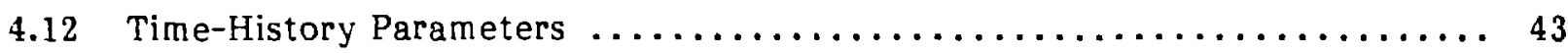

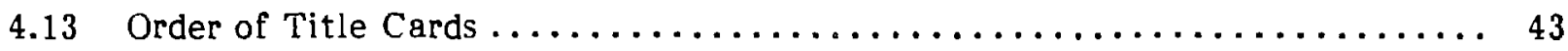

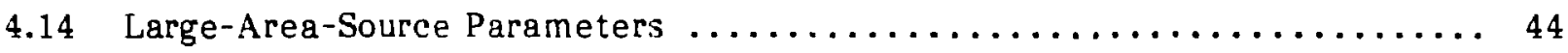

A.1 Functions of New and Modified MILDOS Modules $\ldots \ldots \ldots \ldots \ldots \ldots \ldots \ldots$

B.1 Comparison between Measured Rn-222 Concentrations and MILDOS-AREA Calculated Concentrations and Working Levels for Monticello, Utah....... 66

B.2 Comparison of AIRDOS-EPA and MILDOS-AREA Radon Concentrations and Working Levels for Monticello, Utah, Site .................. 67

C.1 Source Descriptions for Sample Problem $2 \ldots \ldots \ldots \ldots \ldots \ldots \ldots \ldots \ldots \ldots \ldots$

C.2 Receptor Locations for Sample Problems 2 and $3 \ldots \ldots \ldots \ldots \ldots \ldots \ldots \ldots \ldots$ 


\section{ACKNOWLEDGMENTS}

The authors were assisted in this work by many experts from the scientific community. Special thanks are due to K.F. Eckerman (Oak Ridge National Laboratory) for providing the age-specific internal dose conversion factors and reviewing the dosimetry models; Roger Nelson (Jacobs Engineering, Inc.), J. M. Bounds, Frank Kornegay, F.R. O'Donnell (Oak Ridge National Laboratory), and J. Wing (DOE) for providing valuable review of the methodology used in this document; K. Karp (UNC Geotech) for providing measured radon concentration and flux data from the Monticello, Utah, mill tailings site for use in the code validation study; S.L. Giardini (then at Argonne National Laboratory [ANL]) for assisting in preparation of an earlier draft version of this report; R.G. Williams (ANL) for providing data on state average annual agricultural production; and Brad Micklich (ANL) for conducting the validation study. Finally, we thank John DePue (ANL) for his editorial assistance. 


\title{
MILDOS-AREA: AN ENHANCED VERSION OF MILDOS FOR LARGE-AREA SOURCES
}

by

Y.C. Yuan, J.H.C. Wang, and A. Zielen

\begin{abstract}
The MILDOS-AREA computer code is a modified version of the MILDOS code, which estimates the radiological imparts of airborne emissions from uranium mining and milling facilities or any other large-area source involving emissions of radioisotopes of the uranium-238 series. MILDOS-AREA is designed for execution on personal computers. The modifications incorporated in the MILDOSAREA code provide enhanced capabilities for calculating doses from large-area sources and update dosimetry calculations. The major revision from the original MILDOS code is the treatment of atmospheric dispersion from area sources: MILDOS-AREA substitutes a finite-element integration approach for the virtual-point method (the algorithm used in the original MILDOS code) when specified by the user. Other revisions include the option of using Martin-Tickvart dispersion coefficients in place of Briggs coefficients for a given source, consideration of plume reflection, and updated internal dosimetry calculations based on the most recent recommendations of the International Commission on Radiation Protection and the agespecific dose calculation methodology developed by Oak Ridge National Laboratory. This report also discusses changes in computer code structure incorporated into MILDOS-AREA, summarizes data input requirements, and provides instructions for installing and using the program on personal computers.
\end{abstract}

\section{INTRODUCTION}

Argonne National Laboratory (ANL) has developed the MILDOS-AREA code by modifying the MILDOS code developed by Strenge and Bander (1981) to evaluate radiological impacts of uranium processing facilities. The changes are intended to provide enhanced capability to compute doses from large-area sources and to incorporate recent changes in methods for dosimetry calculations. The revised program is designed for use on IBM or IBM-compatible personal computers (PCs).

A sector-averaged Gaussian plume-dispersion model is used to compute concentrations of radioactive materials from fixed-point sources. In the original MILDOS code, area sources are handled by a virtual-point method. The new MILDOS-AREA code 
provides the user with the option of using a finite-element integration method for area sources. A choice of vertical-dispersion coefficients also is available in MILDOSAREA: Briggs (recommended for elevated sources) or Martin-Tickvart (recommended for ground-level sources). The latter is an option added to the new code.

Wind-frequency data are provided by the user. The transport model includes the mechanisms of dry deposition of particulates, resuspension, radioactive decay and progeny ingrowth, and plume reflection. Deposition buildup and ingrowth of radioactive progeny are considered in estimating surface concentrations, which are modified by radioactive transformation, weathering, and other environmental processes. MILDOSAREA allows the user to vary the emission rates of the sources as a step function of time. Thus, the changing processes (including shutdown) throughout the operational lifetime of one or more source facilities can be simulated.

Impacts to humans through such pathways as inhalation, external exposure (from ground concentrations and cloud immersion), and ingestion (of vegetables, meat, and milk) are estimated based on calculated annual average air concentrations of radionuclides. Individual dose commitments, total individual dose commitments (considering ali radionuclides), and annual population dose commitments (regional, extraregional, total, and cumulative) are available from the MILDOS-AREA code. Dose commitments (including age-specific considerations) are calculated with conversion factors derived from recommendations of the International Commission on Radiological Protection (ICRP) and Oak Ridge National Laboratory. These factors are provided internally to the program and are not part of user input.

In addition to discussing new and modified routines, this report also presents (1) a brief discussion of the theory behind the finite-element integration technique and other modifications, (2) information concerning the input required, (3) instructions for installing and using the new code on PCs, and (4) sample problems. Appendix A summarizes information on program structure and data transfer in MILDOS-AREA.

This report is intended to supplement, not replace, the information provided in the user's manual for MILDOS, prepared by Strenge and Bander (1981). Accordingly, the user is expected to be familiar with the original version of MILDOS. 


\section{THEORETICAL BACKGROUND FOR PROGRAM MODIFICATIONS}

This chapter briefly discusses the theoretical foundations of the principal changes incorporated into MILDOS-AREA. The first subsection introduces the finiteelement integration approach for treating atmospheric dispersion from area sources and outlines the formliation of the new atmospheric dispersion model for area sources. Subsequent subsections present the rationale for the changes made in the methods used to compute vertical-dispersion coefficients, concentrations, source strength, mixing height, and dose conversion factors.

\subsection{ATMOSPHERIC DISPERSION FROM AREA SOURCES}

The conventional Gaussian plume model is an analytic solution for the atmospheric dispersion of a point source. A virtual-point method was used in the original MILDOS code to apply the model further to an area source. However, that method provides only a rough approximation of conditions. To simulate accurately the size and shape of a large-area source and to improve the efficiency of the computations, a finiteelement integration scheme has been incorporated as an option in the MILDOS-AREA code. A major advantage of the finite-element method is that it permits the large-area sources to be partitioned into triangles, rectangles, or elements of other arbitrarily selected shapes. Thus, curved or irregular boundaries can be accurately described with a minimum number of mesh points. The theoretical bases for applying the finite-element integration method to atmospheric dispersion from large-area sources are described below.

At a receptor location of interest, the atmospheric concentration of particulates or gases from an area source can be determined by integrating a point-source dispersion concentration over the entire source area:

$$
x\left(\vec{r}_{p}\right)=f_{A} x_{p}\left(\vec{r}_{p}-\vec{r}_{s}\right) d A
$$

where:

$$
\begin{aligned}
& x\left(\vec{r}_{p}\right)=\begin{array}{l}
\text { the air concentration at receptor } \vec{r}_{p} \text { due to the area } \\
\text { source, }
\end{array} \\
& A=\text { the grea of the source, and } \\
& x_{p}\left(\vec{r}_{p}-\vec{r}_{s}\right)=\underset{\text { the air concentration at receptor } \vec{r}_{p} \text { resulting from a }}{\text { point source with location } \vec{r}_{s} .}
\end{aligned}
$$


The integrand in Eq. 1 is related to a point-source relative-release concentration, $\left(\frac{x}{Q}\right)_{p}\left(\vec{r}_{p}-\vec{r}_{s}\right)$, by

$$
x_{p}\left(\vec{r}_{p}-\vec{r}_{s}\right)=Q\left(\vec{r}_{s}\right)\left(\frac{X}{Q}\right)_{p}\left(\vec{r}_{p}-\vec{r}_{s}\right)
$$

where:

$$
Q\left(\vec{r}_{s}\right)=\text { the source strength at } \vec{r}_{s} \text {. }
$$

Substitution of Eq. 2 into Eq. 1 yields

$$
X\left(\vec{r}_{p}\right)=\int_{A} Q\left(\vec{r}_{S}\right)\left(\frac{X}{Q}\right)_{P}(\vec{r}) d A
$$

where:

$$
\vec{r}=\vec{r}_{p}-\vec{r}_{s} \text {. }
$$

The integration of Eq. 3 can be performed using the finite-element method (Yuan 1979). In this method, the problem domain (the total area $A$ of the source) is first partitioned into contiguous subdomains. The area $\mathrm{A}$ must be divided into a number of connecting, but nonoverlapping, subareas or finite elements $a_{i}(i=1,2, \ldots, n)$ such that for each element, a uniform source strength $Q_{i}=Q\left(\vec{r}_{i}\right)$ may be assumed. Equation 3 can thus be rewritten as

$$
x\left(\vec{r}_{p}\right)=\sum_{i=1}^{n} \int_{a_{i}} Q_{i}\left(\frac{x}{Q}\right)_{p}(\stackrel{\vec{L}}{i}) d_{i}
$$

where:

$$
\sum_{i=1}^{n} a_{i}=A
$$

Once the subdivisions of the source area have been designated, an approximate source relative-release concentration is then sought through use of piecewise polynomials with appropriate continuity conditions across interelement boundaries:

$$
\left(\frac{x}{Q}\right)_{p}(\vec{r}) \simeq \sum_{j=1}^{m} h_{j}(\vec{r})\left(\frac{x}{Q}\right)_{P}\left(\vec{r}_{j}\right)
$$

where:

$$
\begin{aligned}
h_{j}(\vec{r})= & \text { the basis function having support only over the element for } \\
& \text { which } \vec{r}_{j} \text { is one of } m \text { vertices. }
\end{aligned}
$$


The unknown coefficients in the polynomial approximation, in this case the $\left(\frac{x}{Q}\right)_{p}\left(\vec{r}_{j}\right)$, are typically nodal values of the dependent variable and are known as trial functions. Substituting Eq. 5 into Eq. 4 gives

$$
x\left(\vec{r}_{p}\right)=\sum_{i=1}^{n}\left[\sum_{j=1}^{m}<h_{j}(\vec{r})>\left(\frac{x}{Q}\right)_{p}, j\right] Q_{i}
$$

where:

$$
\begin{aligned}
\left\langle h_{j}(\vec{r})\right\rangle & =\int_{a_{i}} h_{j}(\vec{r}) d a_{i} \\
& =\iint_{a_{i}} h_{i}(x, y) d x d v .
\end{aligned}
$$

The number of nodes per element depends on the shape of the element and the degree of accuracy desired. Triangles and rectangles are the shapes most commonly used in finite-eleme" analysis. Of the two, triangles are better for approximating a curved boundary; otherwise, however, use of rectangles can simplify data input while maintaining a high degree of accuracy. Therefore, for a large-area source, rectangles are usually the better choice. The simplest trial function for rectangular elements is based on functions that are piecewise bilinear in each rectangle:

$$
x(x, y)=a_{1}+a_{2} x+a_{3} y+a_{4} x y .
$$

The four coefficients $a_{j}$ can be determined by substituting the values of $x$ at the four vertices. Equation 7 can also be written as

$$
x(x, y)=\sum_{j=1}^{4} h_{j}(x, y) x_{j}\left(x_{j}, y_{j}\right)
$$

where:

$$
h_{j}(x, y)=\left\{\begin{array}{l}
1, x=x_{j}, y=y_{j} \\
0 \text { at other nodes. }
\end{array}\right.
$$

To combine the advantages of triangular and rectangular elements, MILDOSAREA uses quadrilateral elements. A polynomial with four coefficients as shown in Eqs. 7 and 8 could be applied to a general quadrilateral, but the piecewise bilinear functions generally would not be continuci' from one element to the next. It is necessary to use an isoparametric transformation to change coordinates in such a manner that the element becomes a rectangle. This isoparametric transformation is illustrated in Fig. 2.1. 


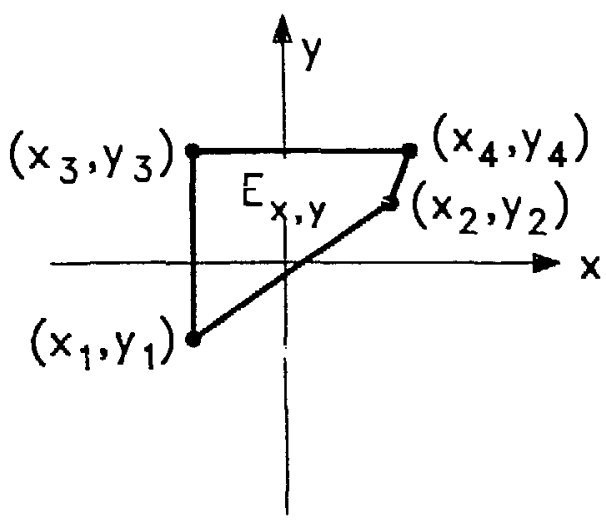

(a)

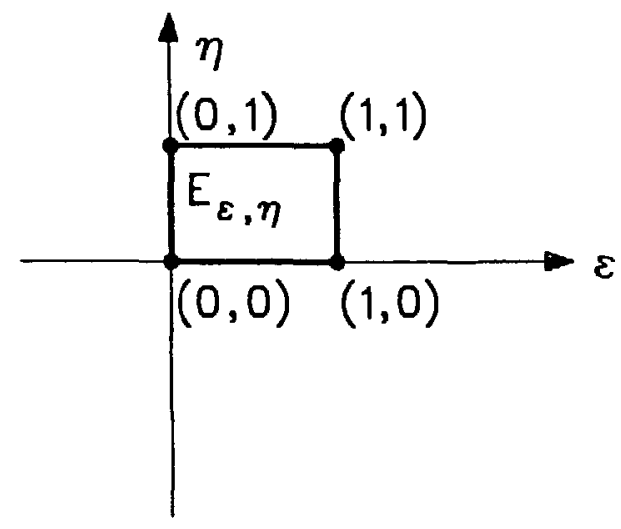

(b)

FIGURE 2.1 Isoparametric Transformation from a Quadrilateral to a Rectangle ( $a=$ original coordinates, $b=$ isoparametrically transformed coordinates)

The coordinate change between $E_{x, y}$ and $E_{\xi, \pi}$ is given by

$$
\begin{aligned}
& x(\xi, n)=x_{1}+\left(x_{2}-x_{1}\right) \xi+\left(x_{3}-x_{1}\right) \eta+\left(x_{4}-x_{3}-x_{2}+x_{1}\right) \xi n \\
& y(\xi, \eta)=y_{1}+\left(y_{2}-y_{1}\right) \xi+\left(y_{3}-y_{1}\right) \eta+\left(y_{4}-y_{3}-y_{2}+y_{1}\right) \xi n
\end{aligned}
$$

With the adoption of these new coordinates in Eqs. 7 and 8, the concentration $x$ will vary linearly along the element edges, thus ensuring continuity. Equation 8 becomes

$$
\begin{aligned}
x(\xi, \eta)= & \sum_{k=1}^{4} h_{k}(\xi, \eta) x\left(\xi_{k}, \eta_{k}\right) \\
= & (1-\xi)(1-\eta) x(0,0)+\xi(1-\eta) x(1,0) \\
& +(1-\xi) \eta x(0,1)+\xi \eta x(1,1) .
\end{aligned}
$$

The basis functions and the tria! functions now have been formulated, and the receptor air concentration from the dispersion of the total area source now can be calculated using Eq. 6. The transformation of the double integral in that equation is given by

$$
\iint_{a_{i}} h_{j}(x, y) d x d y=\int_{0}^{1} \int_{0}^{1} h_{j}[x(\xi, \eta), y(\xi, \eta)] J(\xi, \eta) d \xi d \eta
$$


where $\mathrm{J}$ is the Jacobian determinant:

$$
J=\frac{\partial x}{\partial \xi} \frac{\partial y}{\partial n}-\frac{\partial x}{\partial \eta} \frac{\partial y}{\partial \xi} .
$$

Substitution of Eq. 9 into Eq. 12 gives

$$
J=A+B \xi+C \eta
$$

where:

$$
\begin{aligned}
& \mathrm{A}=\mathrm{X} 21 \cdot \mathrm{Y} 31-\mathrm{X} 31 \cdot \mathrm{Y} 21, \\
& \mathrm{~B}=\mathrm{X} 21 \cdot \mathrm{YA}-\mathrm{Y} 21 \cdot \mathrm{XA}, \text { and } \\
& \mathrm{C}=\mathrm{Y} 31 \cdot \mathrm{XA}-\mathrm{X} 31 \cdot \mathrm{YA},
\end{aligned}
$$

and where:

$$
\begin{aligned}
& \mathrm{X} 21=\mathrm{x}_{2}-\mathrm{x}_{1}, \\
& \mathrm{X} 31=\mathrm{x}_{3}-\mathrm{x}_{1}, \\
& \mathrm{Y} 21=\mathrm{y}_{2}-\mathrm{y}_{1}, \\
& \mathrm{Y} 31=\mathrm{y}_{3}-\mathrm{y}_{1}, \\
& \mathrm{XA}=\mathrm{x}_{4}-\mathrm{x}_{3}-\mathrm{x}_{2}+\mathrm{x}_{1}, \text { and } \\
& \mathrm{YA}=\mathrm{y}_{4}-\mathrm{y}_{3}-\mathrm{y}_{2}+\mathrm{y}_{1} .
\end{aligned}
$$

Expression 11 is found to be equivalent to

$$
\begin{aligned}
(A I & +B I+C I) C_{1}+(A I+2 \cdot B I+C I) C_{2} \\
& +(A I+B I+2 \cdot C I) C_{3}+[A I+2 \cdot(B I+C I)] C_{4}
\end{aligned}
$$

where:

$$
\begin{aligned}
& \mathrm{AI}=\mathrm{A} / 4, \\
& \mathrm{BI}=\mathrm{B} / 12, \\
& \mathrm{CI}=\mathrm{C} / 12, \text { and }
\end{aligned}
$$

$C_{1}, C_{2}, C_{3}, C_{4}=$ the values of $\left(\frac{x}{Q}\right)_{p}, j$, for $j=1$ to 4 , respectively. 
The values $C_{1}, \ldots, C_{4}$ are estimated by subdividing a reference area into finite elements. The most convenient choice is the quadrilateral element in the polar $(\mathbf{r}, \theta)$ coordinate system, with two straight edges of the element lying along two adjacent wind directions of the meteorological data set. This is shown in Fig. 2.2, where a point source of ith unit source strength is assumed to be located $a^{t}$ the center ( $\vec{r}_{s}$ ) and where elements are constructed according to the standard 16 wind directions and 45 distances $\left(\mathbf{r}_{n}\right)^{*}$ in the current version of the code. With this arrangement, the nodal values $\left(\mathrm{C}_{1}, \ldots\right.$, $\mathrm{C}_{4}$ ) can be computed using the Gaussian dispersion model from a point source. The elements essentially are equivalent to simple rectangular elements, because $r$ or $\theta$ is constant on the sides of each element. The nodal values are given by

$$
\begin{aligned}
\left(\frac{x_{j}}{Q_{p}}(r, \theta)\right. & =\sum_{j=1}^{4} \xi_{j}(r, \theta)\left(\frac{x}{Q}\right)_{p, j} \\
& =b_{1}+b_{2} \theta+b_{3} \ln (r)+b_{4} \theta \ln (r) \\
& \text { or } \\
& =b_{1}+b_{2} \partial+b_{3} r+b_{4} \theta r
\end{aligned}
$$

where, again, the values of $b_{j}$ are determined by the values of $\left(\frac{X}{Q}\right)$ at the vertices. The expression in Eq. $13 \mathrm{a}$ is essentially a weighted average of $\mathrm{C}_{1}, \ldots, \mathrm{C}_{4}$, with the relative weights depending on the location of $(r, \theta)$ within the element. The natural logarithm of $r$ (Eq. 13b) is used as the default option in the code because of the exponential nature of ihe relationship between concentration and distance from a point source. Equation $13 \mathrm{c}$ is also implemented in the ccde as an alternative.

After the point-source relative-release conceritrations are approximated for each element, they are multiplied by the source strength for that same element. Then, as seen in Eq. 6, these products are summed over all the elements, yielding the desired concentration value $x$ for $\vec{r}_{p}=(x, y)$.

To simplify the task of entering detailed element coordinates for area sources, an automeshing algorithm has been developed as an option in the code. With this option, instead of entering every required value for each element, the user needs only to enter the vertex coordinates of the bounding quadrilateral area. The program then automatically generates topographically equal-intervaled meshes for the area according to the number of elements specified by the user. For example, a 12-element (3 x 4$)$ quadrilateral area is entered as four corner nodes, and NEX (3) and NEY (4) specify the number of elements on bottom and left sides (or topographical $x$ and $y$ directions). Figure 2.3 illustrates the nodes.

*Default values for $r_{n}$ are (in meters) $0,10,15,20,30,40,50,60,80,100,150,200,300$, $400,600,800,1,000,1,200,1,600,1,800,2,000,3,000,4,000,5,000,6,000,7,000,8,000$, $9,000,10,000,15,000,20,000,25,000,30,000,35,000,40,000,45,000,50,000,60,000$, $70,000,80,000,100,000,120,000,140,000$, and 160,000 . 


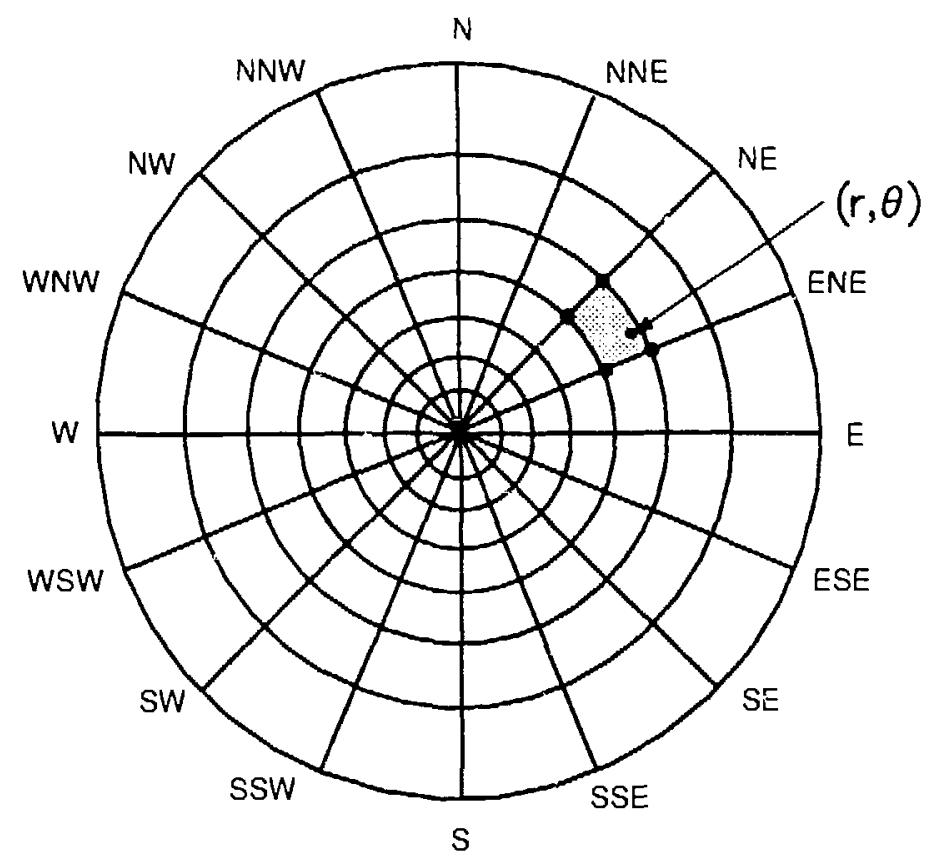

FIGURE 3.2 Annulus/Sector Reference Area for a Given Point $(r, \theta)$ Relative to a Point Source of Unit Strength at Point $(0,0)$

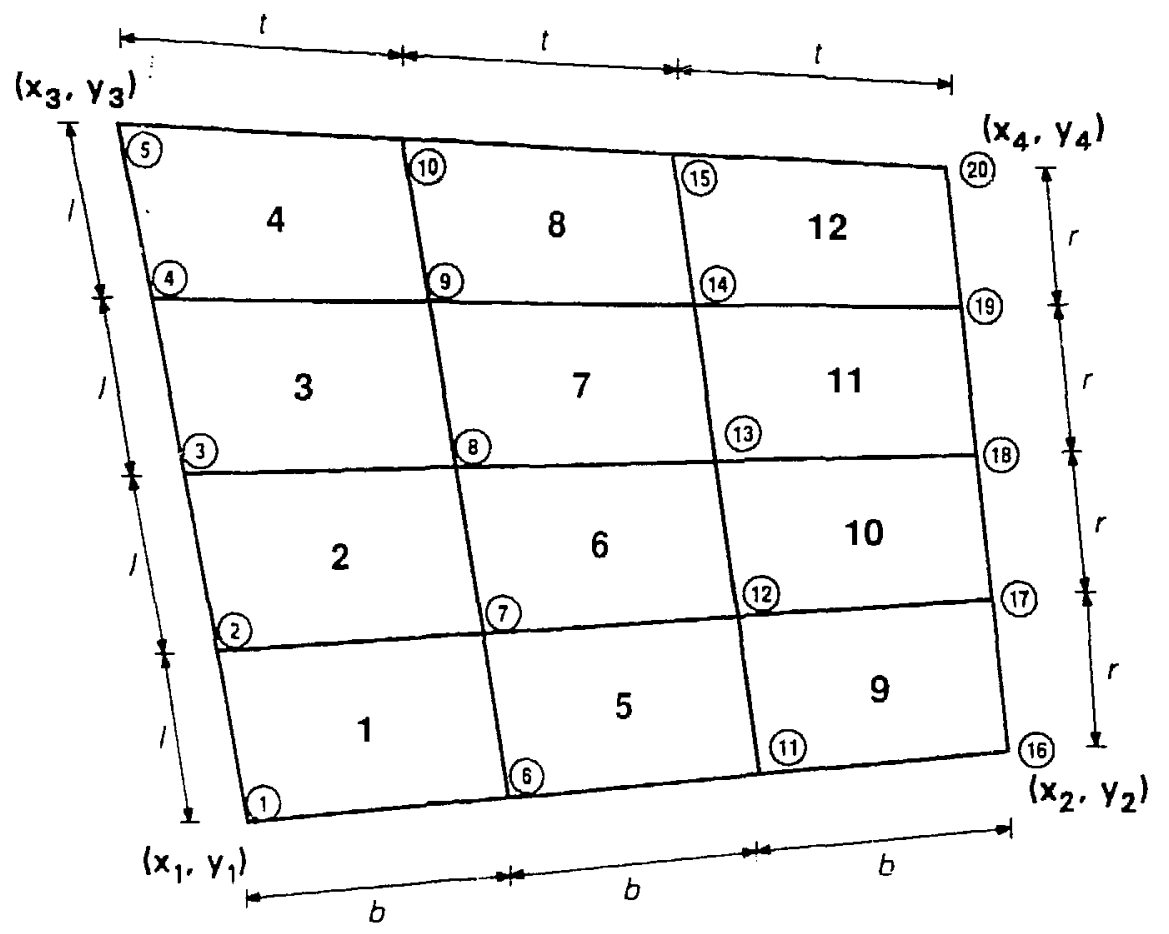

PIGURE 2.3 Automatic Meshing of a Large Quadrilateral

Area (node numbers are enclosed in a circle, and the element numbers are noted at the center of each element) 


\subsection{VERTICAL-DISPERSION COEFPICIENTS FOR GROUND-LEVRL SOURCEO}

The empirical expression used to calculate the vertical-dispersion coefficient $\left(\sigma_{z}\right)$ in the original version of MILDOS is based primarily on data for aboveground sources. The resulting Briggs dispersion coefficients are most appropriate for a tall source, such as a power-plant stack, and are less appropriate for ground-level sources, such as tailings piles (Gifford 1976). A more suitable formula for the latter class of sources is given by Martin and Tickvart (1968):

$$
\sigma_{z}=A x^{B}+C
$$

where the constants $A, B$, and $C$ are as defined in Table 2.1 for each stability class and for three ranges of the downwind distance, $x$. An additional advantage of the MartinTickvart coefficients is that Eq. 14 can be used to compute dispersion coefficients for downwind distances of less than $100 \mathrm{~m}$, thus providing a more realistic representation of pollutant dispersion for near-source receptors.

\subsection{PLUME REFLECTION}

Physical boundaries (the atmospheric mixing layer and the ground surface) are important considerations in assessing atmospheric dispersion at great distances from the sources or for near-ground emissions. This is because the rate of dispersion across the boundaries (ground surface and top of the mixing layer) is small compared with the rate of dispersion within the mixing layer. In MILDOS-AREA, the plume is conservatively assumed to be ieflected by the boundaries. From Powell et al. (1979), the straight-line, crosswind-integrated Gaussian equation for a plume with vertical distribution limited by reflections may be written as

$$
x(x)=\frac{Q}{\bar{u}(\pi x / 8) z}
$$

where:

$$
z^{L}= \begin{cases}\frac{1}{\sqrt{\pi / 2} \sigma_{z}} \exp \left[-\frac{1}{2}\left(\frac{H}{\sigma_{z}}\right)^{2}\right]+\exp \left[-\frac{1}{2}\left(\frac{2 \mathrm{~L}-\mathrm{H}}{\sigma_{z}}\right)^{2}\right]+\exp \left[-\frac{1}{2}\left(\frac{2 \mathrm{~L}+H}{\sigma_{z}}\right)^{2}\right] \\ \frac{1}{\sqrt{\pi / 2} \sigma_{z}} & \exp \left[-\frac{1}{2}\left(\frac{H}{\sigma_{z}}\right)^{2}\right] \\ -1 & \end{cases}
$$

and where:

$$
\begin{aligned}
& \bar{u}=\text { average wind speed } \\
& \mathrm{x}=\text { downwind distance, }
\end{aligned}
$$


TABLE 2.1 Values of Constants Used to Estimate Martin-Tickvart Vertical-Dispersion Coefficients

\begin{tabular}{|c|c|c|c|c|}
\hline \multirow{2}{*}{$\begin{array}{c}\text { Downwind } \\
\text { Distance } \\
(\mathrm{m})\end{array}$} & \multirow[b]{2}{*}{$\begin{array}{c}\text { Stability } \\
\text { Class }\end{array}$} & \multicolumn{3}{|c|}{ Constant } \\
\hline & & A & B & C \\
\hline \multirow[t]{6}{*}{$>1,000$} & A & 0.00024 & 2.094 & -9.6 \\
\hline & B & 0.055 & 1.098 & 2.0 \\
\hline & C & 0.113 & 0.911 & 0 \\
\hline & D & 1.26 & 0.516 & -13 \\
\hline & $\mathrm{E}$ & 6.73 & 0.305 & -34 \\
\hline & $\mathrm{F}$ & 18.05 & 0.18 & -48.6 \\
\hline \multirow[t]{6}{*}{$1,000-100$} & A & $0.00066^{b}$ & 1.941 & 9.27 \\
\hline & $\mathrm{B}$ & $0.0382^{c}$ & 1.149 & 3.3 \\
\hline & $\mathrm{C}$ & 0.113 & 0.911 & 0 \\
\hline & $D$ & 0.222 & 0.725 & -1.7 \\
\hline & $E$ & 0.211 & 0.678 & $-1 \cdot 3$ \\
\hline & $E$ & 0.086 & 0.74 & -0.35 \\
\hline \multirow[t]{6}{*}{$<100$} & A & 0.192 & 0.936 & 0 \\
\hline & B & 0.156 & 0.922 & 0 \\
\hline & C & 0.116 & 0.905 & 0 \\
\hline & D & 0.079 & 0.881 & 0 \\
\hline & E & 0.063 & 0.871 & 0 \\
\hline & $\mathrm{F}$ & 0.053 & 0.814 & 0 \\
\hline
\end{tabular}

$a_{A}=$ extremely unstable, $B=$ moderately unstable, $C=$ slightly unstable, $D=$ neutral, $E=$ moderately stable, $F=$ very stable.

${ }^{b}$ Changed from the value of 0.0015 , which was a typographical error in the original work.

${ }^{c}$ Changed from the value of 0.028 , which was a typographical error in the original work.

Source: Modified from Eimutis and Konicek 1972. 

$z=$ receptor height,
$\mathrm{L}=\operatorname{mixing}$ height, and
$\mathrm{H}=$ relative receptor height (the difference between the effective stack height and receptor height).

Equations $15 \mathrm{c}$ and $15 \mathrm{~d}$ are the simpler asymptotic forms used in the previous version of MILDOS, i.e., reflections from the top of the mixing layer were ignored when $\sigma_{2}$ was small compared to $L$, and the even distribution was assumed when $\sigma_{z}$ was on the order of L. These two simpler evaluations are used in MILDOS-AREA instead of the more complex (and hence more extensively computed) Eq. 15b subject to the following conditions:

1. The simple Gaussian distribution, Eq. 15c, may be used where

$$
\frac{\sigma_{2}}{L} \leq r_{1}=\frac{\sqrt{1-H / L}}{1.20}
$$

2. The even distribution, Eq. $15 \mathrm{~d}$, may be used

a. for $0 \leq \mathrm{H} / \mathrm{L}<0.5$, where

$$
\frac{\sigma_{z}}{L} \geq r_{2}=-2.37\left(\frac{H}{L}\right)^{2}+0.489\left(\frac{H}{L}\right)+0.756 \text { and }
$$

b. for $0.5 \leq \mathrm{H} / \mathrm{L}<1.0$, where

$$
\frac{\sigma_{z}}{L} \geq r_{2}=-2.37\left(\frac{H}{L}\right)^{2}+4.25\left(\frac{H}{L}\right)-1.13 .
$$

If none of these conditions holds, Eq. $15 \mathrm{~b}$ is used. Equation $15 \mathrm{~b}$ is a simplification of an equation involving a summation to account for the effects of multiple reflections. The assumption of one reflection from the ground and one from the top of the mixing layer inherent in Eq. 15b leads to a truncation error of not more then $3 \%$ (Powell et al. 1979).

\subsection{DECREASE IN SOURCE STRENGTH DUE TO DRY DEPOSITION}

The concentration in the plume is depleted by the mechanisms of dry deposition, wet deposition, and radioactive decay. To simplify the data-entry requirements, only dry deposition is considered to be a significant deposition process in the plume concentration calculations for the MILDOS-AREA code. Equations 1.2-18 through 2.2-22 in the MILDOS user's manual (Strenge and Bander 1981) have been modified to reflect the 
changes described in Sec. 2.3 of this manual. I. equal to

$$
o_{z}\left(x_{1}\right)=r_{1} L, o_{z}\left(x_{2}\right)=r_{2} L
$$

where:

$$
r_{1}, r_{2} \text {, and } L \text { are as defined in Sec. 2.3. }
$$

The transformed equations become

$$
\begin{aligned}
& Q(x)=Q(0) \exp \left[\frac{-V_{d}}{\bar{u}} F_{1}(0, x)\right] \text { for } x \leq x_{1}, \\
& Q(x)=Q(0) \exp \left\{\frac{-V_{d}}{\bar{u}}\left[F_{1}\left(0, x_{1}\right)+F_{2}\left(x_{1}, x\right)\right]\right\} \\
& \text { for } x_{1}<x \leq x_{2} \text {, and } \\
& Q(x)=Q(0) \operatorname{exo}\left\{\frac{V_{d}}{\bar{u}}\left[F_{1}\left(0, x_{1}\right)+F_{2}\left(x_{1}, x_{2}\right)+\frac{x-x_{2}}{L}\right]\right\} \\
& \text { for } x>x_{2}
\end{aligned}
$$

where:

$$
\begin{aligned}
& Q(0)=\text { source strength at } x=0, \text { and } \\
& Q(x)=\text { source strengtin at } x \text {. }
\end{aligned}
$$

In this case

$$
\begin{aligned}
& F_{1}\left(x_{a}, x_{b}\right)=\int_{x_{a}}^{x_{b}} \frac{\exp \left[-\frac{1}{s}\left(H / \sigma_{z}\right)^{2}\right]}{\sigma_{z}} d x \text {, and } \\
& F_{2}\left(x_{a}, x_{b}\right)=\int_{x_{a}}^{x_{b}} \frac{\exp \left[-\frac{1}{2}\left(\frac{H}{\sigma_{z}}\right)^{2}\right]+\exp \left[-\frac{1}{2}\left(\frac{2 L-H}{\sigma_{z}}\right)^{2}\right]+\exp \left[-\frac{1}{z}\left(\frac{2 L-H}{\sigma_{z}}\right)^{2}\right]}{\sigma_{z}} d x
\end{aligned}
$$

Integration of Eqs. $19 \mathrm{a}$ and $19 \mathrm{~b}$ is computed numerically using the Newton-Cotes routine in the code. 


\subsection{AVERAGE MIXING HEIGHT}

In the original MILDOS code, only one equation is provided to calculate the annual average height of the mixing layer, without considering the effect of atmospheric stability. MILDOS-AREA computes the mean annual mixing height, $L$, based on the mean innual morning and af ternoon mixing heights, $\mathrm{L}_{\mathrm{am}}$ and $\mathrm{L}_{\mathrm{pm}}$, supplied by the user. As in a U.S. Environmental Protection Agency (1978) workbook of air quality models:

$$
\begin{aligned}
& \mathrm{L}=1.5 \mathrm{~L}_{\mathrm{pm}} \text {, for an extremely unstable atmosphere, and } \\
& \mathrm{L}=\left(\mathrm{L}_{\mathrm{am}}+\mathrm{L}_{\mathrm{pm}}\right) / 2 \text {, for a nelitral atmosphere. }
\end{aligned}
$$

For the other unstable classes, $L$ is taken to be equal to $L_{\text {pin }}$. The mixing height $L$ does not apply to the cases of stable atmosphere.

\subsection{INTERNAL DOSE CONVERSION FACTORS}

Internal dose can not be measured directly; it is inferred from estimates of intake by application of radiation physics and mathematical models of translocation and metabolism of the radioactive material in the body. Since development of the original MILDOS code, metabolism data bases and concepts of radiation quantity and radiation bioeffeat have changed substantially. The MILDOS-AREA code incorgorates the new information but maintains the same simplicity of dose factor form as provided in the original MILDOS code. The methods used in MILDOS-AREA to compute internal doses are described below.

\subsubsection{Inhalation}

The inhalation dose factors incorporated into MILDOS-AREA are calculated using the dosimetric model from the International Commission on Radiological Protection (ICRP) Publication 30 (ICRP 1979). Values of committed dose equivalent $\left(\mathrm{H}_{50}\right)$ per unit intake given in the ICRP report are for a radionuclide with an activity median aerodynamic diameter (AMAD) of $1 \mu \mathrm{m}$ (Table 2.2). Values of $\mathrm{H}_{50}$ for an aerosol with a different AMAD can be estimated by the following:

$$
\frac{H_{50}(A M A D)}{H_{50}(1 \mu m)}=E_{N-P}\left(\frac{D_{N-P}(A M A D)}{D_{N-P}(1 \mu m)}\right)+F_{T-B}\left(\frac{D_{T-B}(A M A D)}{T_{T-B}(1 \mu m)}\right)+F_{P}\left(\frac{D_{P}(A M A D)}{D_{P}(1 \mu m)}\right)
$$

where:

$f_{i}=$ fraction of the committed dose equivalent in the reference tissue resulting from deposition in respiratory region i (Table 2.3),

$D_{i}=$ deposition probabilities in respiratory region $\mathrm{i}$ for a given AMAD (ICRP Task Group on Lung Dynamics 1966), and 

$\mathrm{i}=$ respiratory region index $(\mathrm{N}-\mathrm{P}, \mathrm{T}-\mathrm{B}$, and $\mathrm{P}$ represent the nasai pharyngeal, trachea-bronchus, and pulmonary regions, respec- tively).

Because the relationship between the AMAD and the dose factor of effective dose equivalent is irregular, the dose factor for a given AMAD is calculated by linear interpolation from a calculated 12-point AMAD data set given in Table 2.4. For

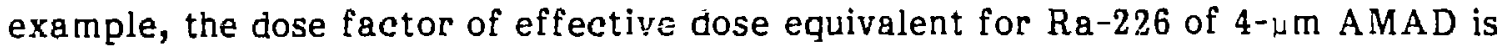

$$
\begin{aligned}
& 5.29 \mathrm{rem!}(\mathrm{i}+(4.34 \mathrm{rem} / \mu \mathrm{Ci}-5.29 \mathrm{rem} / \mu \mathrm{Ci}) \times(4 \mu \mathrm{m}-3 \mu \mathrm{m}) /(5 \mu \mathrm{m}-3 \mu \mathrm{m}) \\
& =4.82 \mathrm{rem} / \omega \mathrm{Ci}
\end{aligned}
$$

The piecewise linear approximation from the 12-point AMAD values provides reasonably accurate description of the effective dose equivalent factor as a function of particle size.

\subsubsection{Age Correction}

Age-specific dose factors are calculated using the methodology from ICRP Publications 26 and 30 (ICRP 1977, 1979) and a report prepared by Oak Ridge National Laboratory for the Nuclear Regulatory Commission (Cristy et al. 1986). The dose factors derived by Cristy et al. (Tables 2.5 and 2.6) are incorporated into MILDOS-AREA as multipliers to calculate the age-specific correction for the ingestion and inhalation dose factors. For inhalation dose factors, Cristy et al. tabulated age-specific factors only for three AMADs -- 0.3, 1, and $5 \mathrm{um}$. In MILDOS-AREA, the age-specific factors are assumed to be a step function of particle size. For AMADs of less than $0.6 \mu \mathrm{m}$, between 0.6 and $3 \mu \mathrm{m}$, and greater than $3 \mu \mathrm{m}$, the correction factors derived by Cristy et al. for $0.3,1$, and $5 \mu \mathrm{m}$, respectively, are used. 
TABLE 2.2 Tissue Dose Factors $\left(\mathrm{H}_{50}\right)$ for AMAD of $1 \mu \mathrm{m}(\mathrm{rem} / \mu \mathrm{Ci})$

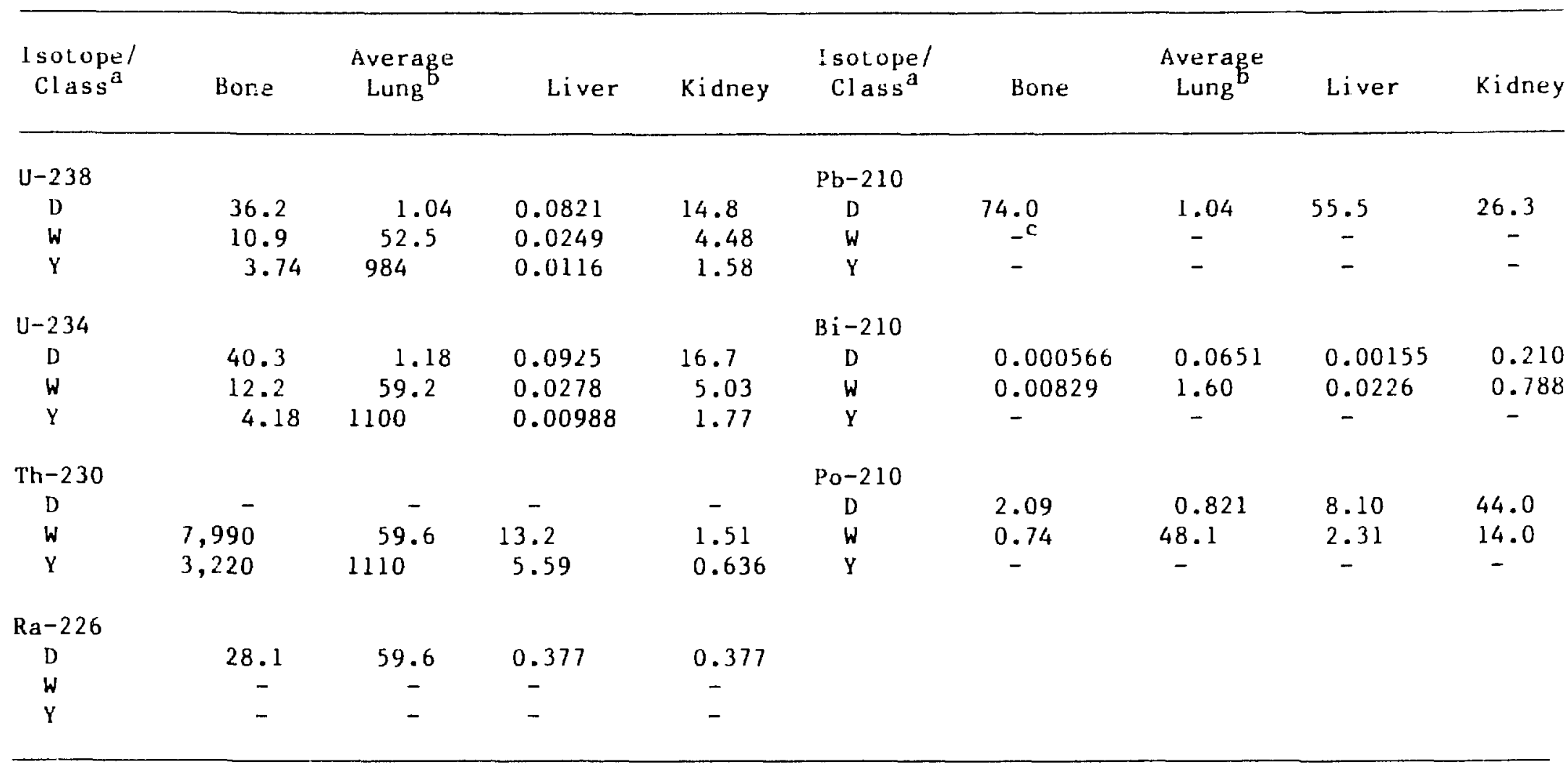

${ }^{a}$ In inhalation dosimetry, inhaled materials are assumed to belong to one of three discrete inhalation classes, according to how rapidly they are removed from the respiratory passages. The inhalation classes are designated as D (removal accomplished in days), W (weeks), and Y (years). A set of parameter values for the dynamics of removal exists for each class.

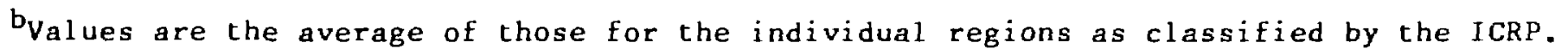

${ }^{c}$ In ICRP classification, some elements do not have all three inhalation classes. For conservatism, the dose factors for unassigned classes in MILDOS-AREA are assumed to be the same as those of the next classes. For example, the dose factors of class D of Th-230 are assigned the same values as those of class $W$. 
TABLE 2.3 Values of the Factors $f_{N-P} / f_{T-P} / f_{P}$

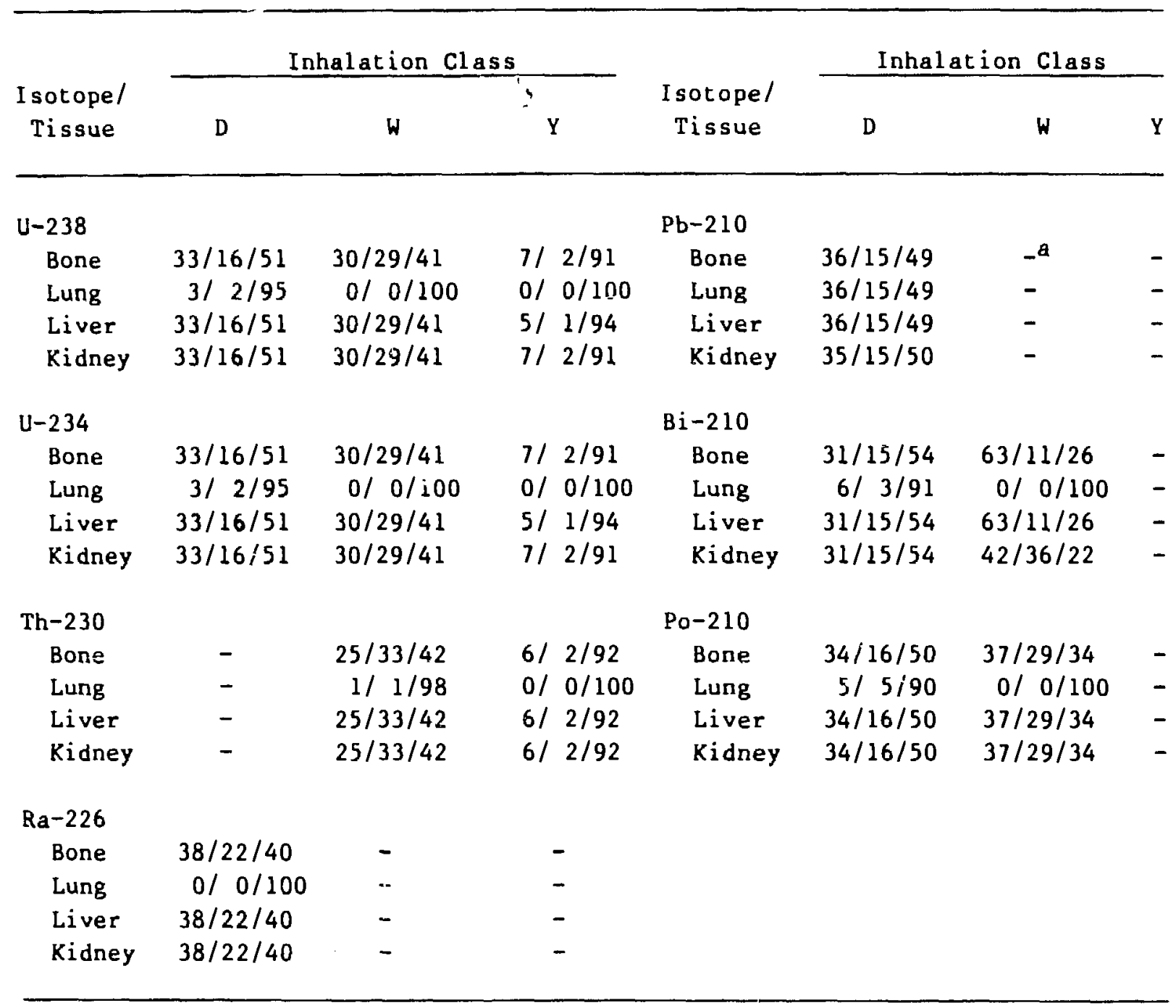

In ICRP classification, some elements do not have all three inhalation classes. For conservatism, the f-values for unassigned classes in MILDOS-AREA are assumed to be the same as those of adjacent classes. For example, the f-values assigned to class $\mathrm{D}$ of $\mathrm{Th}-230$ are the same as those of class $W$. 
TABLE 2.4 Inhalation Effective Dose Equivalent Factors $^{\mathrm{a}}(\mathrm{rem} / \mathrm{\mu Ci})$

\begin{tabular}{|c|c|c|c|c|c|c|c|c|c|c|c|c|c|c|}
\hline \multirow{2}{*}{$\begin{array}{l}\text { AMAD } \\
(\mu \mathrm{m})\end{array}$} & \multicolumn{4}{|c|}{$\mathrm{U}-238$} & \multicolumn{4}{|c|}{$U-234$} & \multicolumn{3}{|c|}{ Th-230 } & \multicolumn{3}{|c|}{$\mathrm{Ra}-226$} \\
\hline & D & \multicolumn{2}{|l|}{$w$} & $Y$ & D & $w$ & \multicolumn{2}{|c|}{$\mathrm{Y}$} & D & $w$ & $Y$ & D & $W$ & $Y$ \\
\hline 0.1 & 4.18 & \multicolumn{2}{|l|}{16.3} & 284 & 4.57 & 18.4 & \multicolumn{2}{|l|}{318} & $-b$ & 588 & 611 & 19.4 & - & - \\
\hline 0.15 & 3.48 & 14.4 & & 253 & 3.88 & 16.2 & \multicolumn{2}{|l|}{283} & - & 465 & 543 & 17.1 & - & - \\
\hline 0.20 & 3.04 & \multicolumn{2}{|l|}{13.1} & 231 & 3.39 & 14.7 & \multicolumn{2}{|l|}{258} & - & 393 & 494 & 15.4 & - & - \\
\hline 0.30 & 2.79 & \multicolumn{2}{|l|}{11.4} & 199 & 3.11 & 12.8 & \multicolumn{2}{|l|}{223} & - & 365 & 428 & 13.5 & - & - \\
\hline 0.50 & 2.57 & \multicolumn{2}{|c|}{9.31} & 161 & 2.86 & 10.5 & \multicolumn{2}{|c|}{181} & - & 340 & 350 & 11.1 & - & - \\
\hline 1.00 & 2.45 & \multicolumn{2}{|c|}{7.01} & 118 & 2.73 & 7.89 & \multicolumn{2}{|c|}{133} & - & 326 & 262 & 8.57 & - & - \\
\hline 2.00 & 2.51 & \multicolumn{2}{|c|}{4.86} & 77.3 & 2.80 & 5.47 & \multicolumn{2}{|c|}{86.6} & - & 330 & 180 & 6.25 & - & - \\
\hline 3.00 & 2.61 & \multicolumn{2}{|c|}{3.95} & 59.4 & 2.90 & 4.44 & \multicolumn{2}{|c|}{66.5} & - & 339 & 144 & 5.29 & - & - \\
\hline 5.00 & 2.74 & \multicolumn{2}{|c|}{3.03} & $4 ! .3$ & 3.05 & 3.40 & \multicolumn{2}{|c|}{46.2} & - & 356 & 109 & 4.34 & - & - \\
\hline 10.00 & 2.27 & \multicolumn{2}{|c|}{2.13} & 23.6 & 3.20 & 2.39 & \multicolumn{2}{|c|}{26.5} & - & 364 & 75.0 & 3.41 & - & - \\
\hline 20.00 & 2.68 & \multicolumn{2}{|c|}{1.23} & 8.58 & 2.98 & 1.37 & \multicolumn{2}{|c|}{9.61} & - & 302 & 43.5 & 2.38 & - & - \\
\hline 50.00 & 2.57 & 0.7 & & 0.071 & 2.87 & 0.792 & & 0782 & - & 266 & 25.7 & 1.80 & - & - \\
\hline & & -210 & & & -218 & & & $0-210$ & & & & & & \\
\hline$(\mu \mathrm{m})$ & D & $W$ & $Y$ & D & $W$ & $Y$ & D & 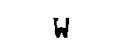 & $Y$ & & & & & \\
\hline 0.1 & 14.9 & - & - & 0.0421 & 0.541 & - & 15.8 & 18.6 & - & & & & & \\
\hline 0.15 & 12.4 & - & - & 0.0360 & 0.470 & - & 13.1 & 16.1 & - & & & & & \\
\hline 0.20 & 10.8 & - & - & 0.0320 & 0.423 & - & 11.4 & 14.4 & - & & & & & \\
\hline 0.30 & 10.0 & - & - & 0.0287 & 0.372 & - & 10.5 & 12.7 & - & & & & & \\
\hline 0.50 & 9.35 & - & - & 0.0251 & 0.313 & - & 9.76 & 10.8 & - & & & & & \\
\hline 1.00 & 9.24 & - & - & 0.0220 & 0.251 & - & 9.50 & 8.84 & - & & & & & \\
\hline 2.00 & 9.86 & - & - & 0.0201 & 0.198 & - & 9.97 & 7.23 & - & & & & & \\
\hline 3.00 & 10.4 & - & - & 0.0198 & 0.178 & - & 10.5 & 6.63 & - & & & & & \\
\hline 5.00 & 11.2 & - & - & 0.0196 & 0.158 & - & 11.1 & 6.08 & - & & & & & \\
\hline 10.00 & 11.9 & - & - & 0.0195 & 0.139 & - & 11.8 & 5.54 & - & & & & & \\
\hline 20.00 & 11.3 & - & - & 0.0174 & 0.109 & - & 11.1 & 4.42 & - & & & & & \\
\hline 50.00 & 11.0 & - & - & 0.0163 & 0.0924 & - & 10.7 & 3.79 & - & & & & & \\
\hline
\end{tabular}

\footnotetext{
${ }^{a}$ The effective dose equivalents are calculated using the ICRP-30 weighting factors.

bIn ICRP classification, some elements do not have all three inhalation classes. For conservatism, the dose factors for unassigned classes in MILDOS-AREA are assumed to be the same as those of adjacent classes. For example, the dose factors assigned to class $D$ of Th-230 are the same as for class $\mathbf{W}$.
} 
TABLE 2.5 Relative Age-Specific Dose Factors (normalized to an adult) from Ingestion

\begin{tabular}{|c|c|c|c|c|}
\hline \multirow{2}{*}{$\begin{array}{l}\text { Isotope/ } \\
\text { Age Group }\end{array}$} & \multicolumn{4}{|c|}{ Dose Factor } \\
\hline & Effective & Bone & Liver & Kidney \\
\hline \multicolumn{5}{|l|}{$U-238$} \\
\hline Infant & 63 & 12 & 32 & 32 \\
\hline Child & 3.9 & 1.3 & 4.4 & 3.9 \\
\hline Teenager & 3.1 & 4.9 & 2.5 & 2.5 \\
\hline \multicolumn{5}{|l|}{$U-234$} \\
\hline Infant & 63 & 13 & 33 & 33 \\
\hline Child & 4 & 1.3 & 4.4 & 3.9 \\
\hline Teenager & 3.1 & 4.9 & 2.5 & 2.5 \\
\hline \multicolumn{5}{|l|}{$T h-234$} \\
\hline Infant & 63 & 12 & 32 & 32 \\
\hline Child & 3.9 & 1.3 & 4.4 & 3.9 \\
\hline Teenager & 3.1 & 4.9 & 2.5 & 2.5 \\
\hline \multicolumn{5}{|l|}{$T h-230$} \\
\hline Infant & 46 & 33 & 170 & 140 \\
\hline Child & 2.8 & 2.5 & $6 . \epsilon$ & 6.1 \\
\hline Teenager & 2.2 & 2.5 & 2.7 & 2.7 \\
\hline \multicolumn{5}{|l|}{$R a-226$} \\
\hline Infant & 16 & 4.3 & 25 & 9.8 \\
\hline Child & 1.8 & 0.99 & 3.9 & 1.9 \\
\hline Teenager & 3.2 & 4.3 & 2.4 & 3 \\
\hline \multicolumn{5}{|l|}{$\mathrm{Pb}-210$} \\
\hline Infant & 6.1 & 2.3 & 16 & 13 \\
\hline Child & 1.7 & 0.97 & 3.9 & 3.4 \\
\hline Teenager & 2.2 & 2.9 & 2.1 & 2.1 \\
\hline \multicolumn{5}{|l|}{$\mathrm{Bi}-210$} \\
\hline Infant & 6.1 & 2.3 & 16 & 13 \\
\hline Child & 1.7 & 0.97 & 3.9 & 3.4 \\
\hline Teenager & 2.2 & 2.9 & 2.1 & 2.1 \\
\hline \multicolumn{5}{|l|}{ Po-210 } \\
\hline Infant & 41 & 78 & 28 & 24 \\
\hline Child & 4.7 & 4.9 & 4.3 & 3.7 \\
\hline Teenager & 2.5 & 3.9 & 2.3 & 2.2 \\
\hline
\end{tabular}


TABLE 2.6 Relative Age-Specific Dose Factors (normalized to an adult) from Inhalation

\begin{tabular}{|c|c|c|c|c|c|c|c|c|c|}
\hline \multirow[b]{3}{*}{ Category } & \multicolumn{9}{|c|}{ Size/Class } \\
\hline & \multicolumn{3}{|c|}{$0.3 \mu \mathrm{m}$} & \multicolumn{3}{|c|}{$1.0 \mu \mathrm{m}$} & \multicolumn{3}{|c|}{$5.0 \mu \mathrm{m}$} \\
\hline & D & $w$ & $Y$ & $\mathrm{D}$ & W & $\mathbf{Y}$ & $D$ & W & $\mathrm{Y}$ \\
\hline $\mathrm{U}-238$ & & & & & & & & & \\
\hline $\begin{array}{l}\text { Effective } \\
\text { Infant } \\
\text { Child } \\
\text { Teenager }\end{array}$ & $\begin{array}{r}21.0 \\
2.9 \\
1.8\end{array}$ & $\begin{array}{r}12.0 \\
3.3 \\
1.5\end{array}$ & $\begin{array}{l}4.8 \\
2.3 \\
1.2\end{array}$ & $\begin{array}{r}22.0 \\
2.9 \\
1.8\end{array}$ & $\begin{array}{r}14.0 \\
3.3 \\
1.6\end{array}$ & $\begin{array}{l}4.8 \\
2.3 \\
1.2\end{array}$ & $\begin{array}{r}23.0 \\
2.9 \\
1.8\end{array}$ & $\begin{array}{r}17.0 \\
3.3 \\
1.7\end{array}$ & $\begin{array}{l}4.8 \\
2.3 \\
1.2\end{array}$ \\
\hline $\begin{array}{l}\text { Bone } \\
\text { Infant } \\
\text { Child } \\
\text { Teenager }\end{array}$ & $\begin{array}{l}4.3 \\
0.96 \\
2.7\end{array}$ & $\begin{array}{l}5.1 \\
1.0 \\
3.0\end{array}$ & $\begin{array}{l}1.9 \\
1.4 \\
1.7\end{array}$ & $\begin{array}{l}4.4 \\
0.96 \\
2.8\end{array}$ & $\begin{array}{l}5.4 \\
1.0 \\
3.1\end{array}$ & $\begin{array}{l}2.1 \\
1.4 \\
1.8\end{array}$ & $\begin{array}{l}4.5 \\
0.97 \\
2.8\end{array}$ & $\begin{array}{l}6.0 \\
1.0 \\
3.2\end{array}$ & $\begin{array}{l}3.2 \\
1.3 \\
2.2\end{array}$ \\
\hline $\begin{array}{l}\text { Lung } \\
\text { Infant } \\
\text { Child } \\
\text { Teenager }\end{array}$ & $\begin{array}{r}13.0 \\
3.4 \\
1.5\end{array}$ & $\begin{array}{r}12.0 \\
3.4 \\
1.5\end{array}$ & $\begin{array}{l}4.7 \\
2.3 \\
1.2\end{array}$ & $\begin{array}{r}13.0 \\
3.4 \\
1.5\end{array}$ & $\begin{array}{r}12.0 \\
3.4 \\
1.5\end{array}$ & $\begin{array}{l}4.7 \\
2.3 \\
1.2\end{array}$ & $\begin{array}{r}13.0 \\
3.4 \\
1.4\end{array}$ & $\begin{array}{r}12.0 \\
3.4 \\
1.5\end{array}$ & $\begin{array}{l}4.8 \\
2.3 \\
1.2\end{array}$ \\
\hline $\begin{array}{l}\text { Liver } \\
\text { Infant } \\
\text { Child } \\
\text { Teenager }\end{array}$ & $\begin{array}{r}11.0 \\
3.1 \\
1.4\end{array}$ & $\begin{array}{r}13.0 \\
3.2 \\
1.5\end{array}$ & $\begin{array}{l}4.4 \\
2.2 \\
1.1\end{array}$ & $\begin{array}{r}12.0 \\
3.1 \\
1.4\end{array}$ & $\begin{array}{r}14.0 \\
3.3 \\
1.6\end{array}$ & $\begin{array}{l}5.0 \\
2.3 \\
1.2\end{array}$ & $\begin{array}{r}12.0 \\
3.2 \\
1.4\end{array}$ & $\begin{array}{r}16.0 \\
3.4 \\
1.6\end{array}$ & $\begin{array}{l}7.7 \\
2.6 \\
1.3\end{array}$ \\
\hline $\begin{array}{l}\text { Kidney } \\
\text { Infant } \\
\text { Child } \\
\text { Teenager }\end{array}$ & $\begin{array}{r}11.0 \\
2.8 \\
1.4\end{array}$ & $\begin{array}{r}13.0 \\
2.9 \\
1.5\end{array}$ & $\begin{array}{l}4.1 \\
2.1 \\
1.1\end{array}$ & $\begin{array}{r}11.0 \\
2.8 \\
1.4\end{array}$ & $\begin{array}{r}14.0 \\
2.9 \\
1.5\end{array}$ & $\begin{array}{l}4.8 \\
2.1 \\
1.2\end{array}$ & $\begin{array}{r}12.0 \\
2.8 \\
1.4\end{array}$ & $\begin{array}{r}15.0 \\
3.0 \\
1.6\end{array}$ & $\begin{array}{l}7.8 \\
2.4 \\
1.3\end{array}$ \\
\hline$v-234$ & & & & & & & & & \\
\hline $\begin{array}{l}\text { Effective } \\
\quad \text { Infant } \\
\text { Child } \\
\text { Teenager }\end{array}$ & $\begin{array}{r}22.0 \\
2.9 \\
1.8\end{array}$ & $\begin{array}{r}12.0 \\
3.4 \\
1.5\end{array}$ & $\begin{array}{l}4.8 \\
2.3 \\
1.2\end{array}$ & $\begin{array}{r}22.0 \\
2.9 \\
1.8\end{array}$ & $\begin{array}{r}14.0 \\
3.4 \\
1.6\end{array}$ & $\begin{array}{l}4.8 \\
2.3 \\
1.2\end{array}$ & $\begin{array}{r}23.0 \\
2.9 \\
1.8\end{array}$ & $\begin{array}{r}17.0 \\
3.3 \\
1.7\end{array}$ & $\begin{array}{l}4.8 \\
2.3 \\
1.2\end{array}$ \\
\hline $\begin{array}{l}\text { Bone } \\
\text { Infant } \\
\text { Child } \\
\text { Teenager }\end{array}$ & $\begin{array}{l}4.3 \\
0.96 \\
2.7\end{array}$ & $\begin{array}{l}5.1 \\
1.0 \\
3.0\end{array}$ & $\begin{array}{l}1.9 \\
1.4 \\
1.7\end{array}$ & $\begin{array}{l}4.4 \\
0.96 \\
2.8\end{array}$ & $\begin{array}{l}5.5 \\
1.0 \\
3.1\end{array}$ & $\begin{array}{l}2.1 \\
1.4 \\
1.8\end{array}$ & $\begin{array}{l}4.5 \\
0.97 \\
2.8\end{array}$ & $\begin{array}{l}6.0 \\
1.0 \\
3.2\end{array}$ & $\begin{array}{l}3.2 \\
1.2 \\
2.2\end{array}$ \\
\hline $\begin{array}{l}\text { Lung } \\
\text { infant } \\
\text { Child } \\
\text { Teenager }\end{array}$ & $\begin{array}{r}13.0 \\
3.4 \\
1.5\end{array}$ & $\begin{array}{r}12.0 \\
3.4 \\
1.5\end{array}$ & $\begin{array}{l}4.8 \\
2.3 \\
1.2\end{array}$ & $\begin{array}{r}13.0 \\
3.5 \\
1.5\end{array}$ & $\begin{array}{r}12.0 \\
3.4 \\
1.5\end{array}$ & $\begin{array}{l}4.8 \\
2.3 \\
1.2\end{array}$ & $\begin{array}{r}13.0 \\
3.5 \\
1.4\end{array}$ & $\begin{array}{r}12.0 \\
3.4 \\
1.5\end{array}$ & $\begin{array}{l}4.8 \\
2.3 \\
1.2\end{array}$ \\
\hline $\begin{array}{l}\text { Liver } \\
\text { Infant } \\
\text { Child } \\
\text { Teenager }\end{array}$ & $\begin{array}{r}11.0 \\
3.1 \\
1.4\end{array}$ & $\begin{array}{r}13.0 \\
3.3 \\
1.5\end{array}$ & $\begin{array}{l}4.6 \\
2.3 \\
1.1\end{array}$ & $\begin{array}{r}12.0 \\
3.2 \\
1.4\end{array}$ & $\begin{array}{r}14.0 \\
3.3 \\
1.6\end{array}$ & $\begin{array}{l}5.3 \\
2.4 \\
1.2\end{array}$ & $\begin{array}{r}12.0 \\
3.2 \\
1.4\end{array}$ & $\begin{array}{r}16.0 \\
3.4 \\
1.6\end{array}$ & $\begin{array}{l}8.3 \\
2.7 \\
1.3\end{array}$ \\
\hline
\end{tabular}


TABLE 2.6 (Cont'd)

\begin{tabular}{|c|c|c|c|c|c|c|c|c|c|}
\hline \multirow[b]{3}{*}{ Category } & \multicolumn{9}{|c|}{$\mathrm{Size} / \mathrm{Class}$} \\
\hline & \multicolumn{3}{|c|}{$0.3 \mu \mathrm{m}$} & \multicolumn{3}{|c|}{$1.0 \mu \mathrm{m}$} & \multicolumn{3}{|c|}{$5.0 \mu \mathrm{m}$} \\
\hline & D & $w$ & $Y$ & $\mathrm{D}$ & $w$ & $y$ & D & W & $Y$ \\
\hline \multicolumn{10}{|c|}{$U-234\left(\operatorname{Con} t^{\prime} d\right)$} \\
\hline \multicolumn{10}{|l|}{ Kidney } \\
\hline Infant & 11.0 & 13.0 & 4.1 & 11.0 & 14.0 & 4.8 & 12.0 & 16.0 & 7.9 \\
\hline Child & 2.8 & 2.9 & 2.1 & 2.8 & 2.9 & 2.1 & 2.8 & 3.0 & 2.4 \\
\hline Teenager & 1.4 & 1.5 & $x .1$ & 1.4 & 1.6 & 1.2 & 1.4 & 1.6 & 1.3 \\
\hline \multicolumn{10}{|l|}{ Th-230 } \\
\hline \multicolumn{10}{|l|}{ Effective } \\
\hline $\operatorname{Inf} \operatorname{ant}$ & 1.8 & 1.8 & 2.9 & 1.8 & 1.8 & 2.9 & 1.7 & 1.7 & 2.8 \\
\hline Child & 1.1 & 1.1 & 1.6 & 1.1 & 1.1 & 1.6 & 1.1 & 1.1 & 1.5 \\
\hline Teenager & 0.91 & 0.91 & 1.1 & 0.91 & 0.91 & 1.1 & 0.89 & 0.89 & 1.0 \\
\hline \multicolumn{10}{|l|}{ Bone } \\
\hline Infant & 1.2 & 1.2 & 1.1 & 1.2 & 1.2 & 1.1 & 1.2 & 1.2 & 1.3 \\
\hline Child & 0.98 & 0.98 & 0.97 & 0.98 & 0.98 & 0.97 & 0.98 & 0.98 & 0.98 \\
\hline Teenager & 1.0 & 1.0 & 1.0 & 1.0 & 1.0 & 1.0 & 1.0 & 1.0 & 1.0 \\
\hline \multicolumn{10}{|l|}{ Lung } \\
\hline Infant & 11.0 & 11.0 & 4.8 & 11.0 & 11.0 & 4.8 & 9.9 & 9.9 & 4.8 \\
\hline Child & 3.3 & 3.3 & 2.3 & 3.3 & 3.3 & 2.3 & 3.0 & 3.0 & 2.3 \\
\hline Teenager & 1.5 & 1.5 & 1.2 & 1.5 & 1.5 & 1.2 & 1.4 & 1.4 & 1.2 \\
\hline \multicolumn{10}{|l|}{ Liver } \\
\hline Infant & 5.2 & 5.2 & 3.1 & 5.3 & 5.3 & 3.4 & 5.4 & 5.4 & 4.8 \\
\hline Child & 2.6 & 2.6 & 1.9 & 2.6 & 2.6 & 1.9 & 2.6 & 2.6 & 2.1 \\
\hline Teenager & 1.1 & 1.1 & 1.0 & 1.1 & 1.1 & 1.1 & 1.1 & 1.1 & 1.1 \\
\hline \multicolumn{10}{|l|}{ Kidney } \\
\hline Infant & 4.5 & 4.5 & 2.8 & 4.6 & 4.6 & 3.1 & 4.7 & 4.7 & 4.3 \\
\hline Child & 2.4 & 2.4 & 1.8 & 2.4 & 2.4 & 1.8 & 2.4 & 2.4 & 2.0 \\
\hline Teenager & 1.1 & 1.1 & 1.0 & 1.1 & 1.1 & 1.1 & 1.1 & 1.1 & 1.1 \\
\hline \multicolumn{10}{|l|}{$\mathrm{Ra}-226$} \\
\hline \multicolumn{10}{|l|}{ Effective } \\
\hline Infant & 12.0 & 12.0 & 12.0 & 12.0 & 12.0 & 12.0 & 11.0 & 11.0 & 11.0 \\
\hline Child & 3.1 & 3.1 & 3.1 & 3.0 & 3.0 & 3.0 & 2.4 & 2.4 & 2.4 \\
\hline Teenager & 1.6 & 1.6 & 1.6 & 1.7 & 1.7 & 1.7 & 2.1 & 2.1 & 2.1 \\
\hline \multicolumn{10}{|l|}{ Bone } \\
\hline Infant & 2.6 & 2.6 & 2.6 & 2.7 & 2.7 & 2.7 & 3.0 & 3.0 & 3.0 \\
\hline Child & 0.85 & 0.85 & 0.85 & 0.85 & 0.85 & 0.85 & 0.87 & 0.87 & 0.87 \\
\hline Teenager & 3.1 & 3,1 & 3.1 & 3.2 & 3.2 & 3.2 & 3.4 & 3.4 & 3.4 \\
\hline
\end{tabular}


TABLE 2.6 (Cont'd)

\begin{tabular}{|c|c|c|c|c|c|c|c|c|c|}
\hline \multirow[b]{3}{*}{ Caregory } & \multicolumn{9}{|c|}{ Size/Class } \\
\hline & \multicolumn{3}{|c|}{$0.3 \mu \mathrm{m}$} & \multicolumn{3}{|c|}{$1.0 \mu \mathrm{m}$} & \multicolumn{3}{|c|}{$5.0 \mu \mathrm{m}$} \\
\hline & D & w & $Y$ & D & $w$ & $Y$ & D & w & $Y$ \\
\hline \multicolumn{10}{|c|}{$\operatorname{Ra}-226$ (Cont 'd) } \\
\hline \multicolumn{10}{|l|}{ Lung } \\
\hline Infant & 12.0 & 12.0 & 12.0 & 12.0 & 12.0 & 12.0 & 12.0 & 12.0 & 12.0 \\
\hline Child & 3.4 & 3.4 & 3.4 & 3.4 & 3.4 & 3.4 & 3.4 & 3.4 & 3.4 \\
\hline Teenager & 1.5 & 1.5 & 1.5 & 1.5 & 1.5 & 1.5 & 1.5 & 1.5 & 1.5 \\
\hline \multicolumn{10}{|l|}{ Liver } \\
\hline Infant & 13.0 & 13.0 & 13.0 & 15.0 & 15.0 & 15.0 & 17.0 & 17.0 & 17.0 \\
\hline Child & 3.0 & 3.0 & 3.0 & 3.1 & 3.1 & 3.1 & 3.3 & 3.3 & 3.3 \\
\hline Teenager & 1.7 & 1.7 & 1.7 & 1.8 & 1.8 & 1.8 & 1.9 & 1.9 & 1.9 \\
\hline \multicolumn{10}{|l|}{ Kidney } \\
\hline Infant & 5.1 & 5.1 & 5.1 & 5.7 & 5.7 & 5.7 & 6.7 & 6.7 & 6.7 \\
\hline Child & 1.4 & 1.4 & 1.4 & 1.5 & 1.5 & 1.5 & 1.6 & 1.6 & 1.6 \\
\hline Teenager & 1.7 & 1.7 & 1.7 & 2.0 & 2.0 & 2.0 & 2.3 & 2.3 & 2.3 \\
\hline \multicolumn{10}{|l|}{$\mathrm{Pb}-210$} \\
\hline \multicolumn{10}{|l|}{ Effective } \\
\hline Infant & 2.4 & 2.4 & 2.4 & 2.5 & 2.5 & 2.5 & 2.7 & 2.7 & 2.7 \\
\hline Child & 1.2 & 1.2 & 1.2 & 1.2 & 1.2 & 1.2 & 1.3 & 1.3 & 1.3 \\
\hline Teenager & 1.2 & 1.2 & 1.2 & 1.3 & 1.3 & 1.3 & 1.3 & 1.3 & 1.3 \\
\hline \multicolumn{10}{|l|}{ Bone } \\
\hline Infant & 0.91 & 0.91 & 0.91 & 0.97 & 0.97 & 0.97 & 1.1 & 1.1 & 1.1 \\
\hline Child & 0.69 & 0.69 & 0.69 & 0.71 & 0.71 & 0.71 & 0.72 & 0.72 & 0.72 \\
\hline Teenager & 1.7 & 1.7 & 1.7 & 1.7 & 1.7 & 1.7 & 1.8 & 1.8 & 1.8 \\
\hline \multicolumn{10}{|l|}{ Lung } \\
\hline Infant & 6.0 & 6.0 & 6.0 & 6.4 & 6.4 & 6.4 & 7.0 & 7.0 & 7.0 \\
\hline Child & 2.8 & 2.8 & 2.8 & 2.9 & 2.9 & 2.9 & 2.9 & 2.9 & 2.9 \\
\hline Teenager & 1.2 & 1.2 & 1.2 & 1.2 & 1.2 & 1.2 & 1.3 & 1.3 & 1.3 \\
\hline \multicolumn{10}{|l|}{ Liver } \\
\hline Infant & 6.3 & 6.3 & 6.3 & 6.7 & 6.7 & 6.7 & 7.3 & 7.3 & 7.3 \\
\hline Child & 2.8 & 2.8 & 2.8 & 2.8 & 2.8 & 2.8 & 2.9 & 2.9 & 2.9 \\
\hline Teenager & 1.2 & 1.2 & 1.2 & 1.2 & 1.2 & 1.2 & 1.3 & 1.3 & 1.3 \\
\hline \multicolumn{10}{|l|}{ Kidney } \\
\hline Infant & 5.1 & 5.1 & 5.1 & 5.4 & 5.4 & 5.4 & 5.9 & 5.9 & 5.9 \\
\hline Child & 2.4 & 2.4 & 2.4 & 2.5 & 2.5 & 2.5 & 2.6 & 2.6 & 2.6 \\
\hline Teenager & 1.2 & 1.2 & 1.2 & 1.2 & 1.2 & 1.2 & 1.3 & 1.3 & 1.3 \\
\hline \multicolumn{10}{|l|}{$\mathrm{Bi}-210$} \\
\hline \multicolumn{10}{|l|}{ Effective } \\
\hline Infant & 2.4 & 2.4 & 2.4 & 2.5 & 2.5 & 2.5 & 2.7 & 2.7 & 2.7 \\
\hline Child & 1.2 & 1.2 & 1.2 & 1.2 & 1.2 & 1.2 & 1.3 & 1.3 & 1.3 \\
\hline Tringer & 1.2 & 1.2 & 1.2 & 1.3 & 1.3 & 1.3 & 1.3 & 1.3 & 1.3 \\
\hline
\end{tabular}




\begin{tabular}{|c|c|c|c|c|c|c|c|c|c|}
\hline \multirow[b]{3}{*}{ Category } & \multicolumn{9}{|c|}{ Size/Class } \\
\hline & \multicolumn{3}{|c|}{$0.3 \mu \mathrm{m}$} & \multicolumn{3}{|c|}{$1.0 \mu \mathrm{m}$} & \multicolumn{3}{|c|}{$5.0 \mu \mathrm{m}$} \\
\hline & D & $w$ & Y & D & $w$ & $Y$ & D & $w$ & $Y$ \\
\hline \multicolumn{10}{|c|}{$B i-210\left(C^{\prime} t^{\prime} d\right)$} \\
\hline \multicolumn{10}{|l|}{ Bone } \\
\hline Inf ant & 0.91 & 0.91 & 0.91 & 0.97 & 0.97 & 0.97 & 1.1 & 1,1 & 1.1 \\
\hline Child & 0.69 & 0.69 & 0.69 & 0.71 & 0.71 & 0.71 & 0.72 & 0.72 & 0.72 \\
\hline Teenager & 1.7 & 1.7 & 1.7 & 1.7 & 1.7 & 1.7 & 1.8 & 1.8 & 1.8 \\
\hline \multicolumn{10}{|l|}{ Lung } \\
\hline Infant & 6.0 & 6.0 & 6.0 & 6.4 & 6.4 & 6.4 & 7.0 & 7.0 & 7.0 \\
\hline Child & 2.8 & 2.8 & 2.8 & 2.9 & 2.9 & 2.9 & 2.9 & 2.9 & 2.9 \\
\hline Teenager & 1.2 & 1.2 & 1.2 & 1.2 & 1.2 & 1.2 & 1.3 & 1.3 & 1.3 \\
\hline \multicolumn{10}{|l|}{ Liver } \\
\hline Infant & 6.3 & 6.3 & 6.3 & 6.7 & 6.7 & 6.7 & 7.3 & 7.3 & 7.3 \\
\hline Child & 2.8 & 2.8 & 2.8 & 2.8 & 2.8 & 2.8 & 2.9 & 2.9 & 2.9 \\
\hline Teenager & 1.2 & 1.2 & 1.2 & 1.2 & 1.2 & 1.2 & 1.3 & 1.3 & 1.3 \\
\hline \multicolumn{10}{|l|}{ Kidney } \\
\hline Inf ant & 5.1 & 5.1 & 5.1 & 5.4 & 5.4 & 5.4 & 5.9 & 5.9 & 5.9 \\
\hline Child & 2.4 & 2.4 & 2.4 & 2.5 & 2.5 & 2.5 & 2.6 & 2.6 & 2.6 \\
\hline Teenager & 1.2 & 1.2 & 1.2 & 1.2 & 1.2 & 1.2 & 1.3 & 1.3 & 1.3 \\
\hline \multicolumn{10}{|l|}{$\mathrm{Po}-210$} \\
\hline \multicolumn{10}{|l|}{ Effective } \\
\hline Infant & 13.0 & 14.0 & 14.0 & 13.0 & 15.0 & 15.0 & 15.0 & 18.0 & 18.0 \\
\hline Child & 3.3 & 3.5 & 3.5 & 3.3 & 3.5 & 3.5 & 3.4 & 3.7 & 3.7 \\
\hline Teenager & 1.4 & 1.6 & 1.6 & 1.4 & 1.6 & 1.6 & 1.5 & 1.7 & 1.7 \\
\hline \multicolumn{10}{|l|}{ Bone } \\
\hline Infant & 24.0 & 33.0 & 33.0 & 25.0 & 36.0 & 36.0 & 26.0 & 40.0 & 40.0 \\
\hline Child & 3.4 & 3.8 & 3.8 & 3.5 & 3.9 & 3.9 & 3.5 & 4.0 & 4.0 \\
\hline Teenager & 2.1 & 2.4 & 2.4 & 2.1 & 2.5 & 2.5 & 2.2 & 2.7 & 2.7 \\
\hline \multicolumn{10}{|l|}{ Lung } \\
\hline Infant & 11.0 & 12.0 & 12.0 & 11.0 & 12.0 & 12.0 & 9.9 & 12.0 & 12.0 \\
\hline Child & 3.4 & 3.4 & 3.4 & 3.3 & 3.4 & 3.4 & 3.3 & 3.4 & 3.4 \\
\hline Teenager & 1.3 & 1.5 & 1.5 & 1.3 & 1.5 & 1.5 & 1.2 & 1.5 & 1.5 \\
\hline \multicolumn{10}{|l|}{ Liver } \\
\hline Infant & 9.1 & 12.0 & 12.0 & 9.5 & 14.0 & 14.0 & 10.0 & 15.0 & 15.0 \\
\hline Child & 3.0 & 3.2 & 3.2 & 3.0 & 3.3 & 3.3 & 3.0 & 3.4 & 3.4 \\
\hline Teenager & 1.3 & 1.5 & 1.5 & 1.3 & 1.5 & 1.5 & 1.3 & 1.6 & 1.6 \\
\hline \multicolumn{10}{|l|}{ Kidney } \\
\hline Infant & 7.9 & 11.0 & 11.0 & 8.2 & 12.0 & 12.0 & 8.7 & 13.0 & 13.0 \\
\hline Child & 2.6 & 2.8 & 2.8 & 2.6 & 2.9 & 2.9 & 2.7 & 3.0 & 3.0 \\
\hline Teenager & 1.2 & 1.5 & 1.5 & 1.3 & 1.5 & 1.5 & 1.3 & 1.6 & 1.6 \\
\hline
\end{tabular}




\section{PROGRAM VALIDATION AND OTHER CONSIDERATIONS}

\subsection{PROGRAM VALIDATION}

A validation study of MILDOS-AREA was conducted using measured Rn-222 concentration and flux data from the Monticello, Utah, uranium mill tailings impoundments. This site was selected because of the availabili;y of a large body of measured radon concentration and flux data. The results of the validation study (detailed in Appendix $B$ ) demonstrated that use of MILDOS-AREA can result in generally good agreement between model-generated and measured Rn-222 concentrations.

\subsection{PROGRAM LIMITATIONS}

The current version of MILDOS-AREA allows the user to define a maximum of 10 sources (point or area), 48 individual receptors, and 10 time steps. The number of sources has been reduced from the 20 allowed in the original MLLOS code because in the revised code a large-area source is considered as a single source rather than as two or more virtual-point sources. Nonetheless, a large-area source now can be subdivided into smaller areas or elements, the number of which is limited by the maximum number of nodes allowed (300). This means that a square source may not contain more than 16 elements on a side; such an arrangement produces $(16+1)^{2}=289$ nodes. A square with 17 elements on a side ( 289 elements) would require $(17+1)^{2}=324$ nodes, thus exceeding the maximum.

MILDOS-AREA considers the same radionuclides (those in the U-238 decay series) as does MILDOS. These radionuclides are U-238, U-234, Th-230, Ra-226, Rn-222, $\mathrm{Po}-218, \mathrm{~Pb}-214, \mathrm{Bi}-214, \mathrm{~Pb}-210, \mathrm{Bi}-210$, and $\mathrm{Po}-210$. However, with proper modification of the code and of the necessary data base associated with each radionuclide of interest, the code also could be used to treat other radionuclides.

\subsection{ACCURACY AND PERFORMANCE OF MILDOS-AREA}

In contrast to the original MILDOS, which could be used only on a mainframe computer, MILDOS-AREA is designed for use on an IBM or IBM-compatible personal computer (PC). There is no loss of capability in the PC operation. In fact, MILDOSAREA is easier to use; more flexible in handling the large amounts of printer output; and although slower in execution, usually exhibits a better net turnaround time does than the original MILDOS. One of the notable features of MILDOS-AREA is the efficiency of the finite-element integration computations.

\subsubsection{Accuracy and Efficiency of Pinite-Element Computations}

Table 3.1 summarizes the results (in terms of percent error) of several executions designed to demonstrate the efficiency and accuracy attained using only a small number of area elements. What is more notable is the computer efficiency of 
TABLE 3.1 Accuracy of Calculated Air Concentrations of a Radionuclide from a Square Area Source of $200 \mathrm{~m}$ by $200 \mathrm{~m}$

\begin{tabular}{rrrrrr}
\hline & \multicolumn{5}{c}{ Percent Error b,c } \\
\cline { 2 - 6 } $\begin{array}{c}\text { Distance } \\
(\mathrm{km})^{\mathrm{a}}\end{array}$ & $\begin{array}{c}\text { Elements } \\
\text { Elements }\end{array}$ & $\begin{array}{c}36 \\
\text { Elements }\end{array}$ & $\begin{array}{c}64 \\
\text { Elements }\end{array}$ & $\begin{array}{c}225 \\
\text { Elements }\end{array}$ \\
\hline 0.10 & -69 & -47 & 17 & 0 & 0 \\
0.20 & 28 & 5 & 2 & 1 & 0 \\
0.30 & 5 & 2 & 0 & 0 & 0 \\
0.40 & 3 & 0 & 0 & 0 & 0 \\
0.50 & 1 & 0 & 0 & 0 & 0 \\
1.00 & 0 & 0 & 0 & 0 & 0 \\
5.00 & 0 & 0 & 0 & 0 & 0 \\
10.00 & 0 & 0 & 0 & 0 & 0 \\
\hline
\end{tabular}

${ }^{a}$ Distance from the center of a source area of $200 \mathrm{~m} \times 200 \mathrm{~m}$ diagonally.

$b_{\text {Percent error }}=\frac{x_{n}-x_{225}}{x_{225}} \times 100$, where $x=$ calculated

concentration and $\mathrm{n}=$ number of elements used.

$\mathrm{C}_{\mathrm{A}}$ negative percent error indicates an underestimate of the concentration, a positive percent error indicates an overestimate.

finite-element integration. The central processing unit (CPU) time used during the runs involving a source divided into 4 and 16 finite elements is less than $5 \%$ of the CPU time used in the corresponding virtual-point source runs of the original MILDOS code.

\subsubsection{Personal Computer Performance}

The execution time of MILDOS-AREA is highly dependent upon the characteristics of the computer that is used and the complexity of the case under study. Table 3.2 summarizes results with four computer systems and the three sample problems included with the distribution diskette. The computers tested were a standard IBM-XT (Intel 8088/8087, 4.8-Mhz), a IBM PS/2 Model 80 (16-Mhz), a Compaq Deskpro 386/20 (Intel $80386 / 80387,20-M h z)$, and a mainframe IBM-3033. The mainframe tests were run on earlier version of MILDOS-AREA and are presented only for comparison with the microcomputer results.

Complete listings of the three sample problems are presented in Appendix C. The first problem, called SAMPLE.DAT, is a relatively simple case illustrating the 
TABLE 3.2 MILDOS-AREA Execution Times

\begin{tabular}{|c|c|c|c|c|}
\hline \multirow[b]{2}{*}{ Test Problem } & \multicolumn{4}{|c|}{ Time (seconds) } \\
\hline & I BM-XT & $\begin{array}{l}\text { IBM PS/ } 2 \\
\text { Model } 80\end{array}$ & $\begin{array}{l}\text { Compaq } \\
386 / 20\end{array}$ & 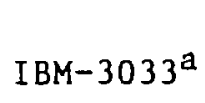 \\
\hline $\begin{array}{l}\text { SAMPLE. DAT } \\
\text { TESTC1.DAT } \\
\text { TESTC2.DAT }\end{array}$ & $\begin{array}{r}525 \\
3,042 \\
3,058\end{array}$ & $\begin{array}{r}96 \\
478 \\
481\end{array}$ & $\begin{array}{r}49.8 \\
307.4 \\
308.3\end{array}$ & $\begin{array}{r}5.50 \\
48.91 \\
49.18\end{array}$ \\
\hline
\end{tabular}

${ }^{a}$ CPU seconds, all others are total elapsed time.

finite-element integration approach for two area sources. The second problem, TESTC1.DAT, is a more realistic example that closely resembles the first sample problem in the MILDOS code manual (Strenge and Bander 1981). The problem includes two point sources, one area source (the ore pad) using the virtual-point method of the original MILDOS, and three tailings area sources using the new finite-element integration. The third problem, TESTC2.DAT, is identical to TESTC1.DAT except the last tailings area is defined as a crescent instead of a rectangle, and manual node numbering is used. The results listed in Table 3.2 indicate that even for the slowest computer tested, the IBM-XT, the most complicated test problem was completed in less than an hour.

\subsection{DATA CONSTANTS}

In MILDOS-AREA, parameters are initialized using a block-data routine, FRESH, and DATA statements in several subroutines. The initial values of input variables are given as defaults in the tables of Chapter 4, which describe the NAMELIST parameters.

Except for internal dose calculation, the values of internally defined, or hardcoded, parameters have not changed from MILDOS to MILDOS-AREA. These values are given in several tables at the end of Sec. 3.0 of the original MILDOS user's manual (Strenge and Bander 1981).

\subsection{ERROR HANDLING}

As in MILDOS, the input parameters are not validated in MILDOS-AREA. The user should carefully examine the first several output reports, which echo the program's interpretation of the NAMELIST input. 


\section{DATA-INPUT PREPARATION}

To execute MILDOS-AREA, the user must supply, in order, a NAMELIST called INDATA, a title-card set, and a NAMELIST called NWAREA for each large-area source. INDATA has been slightly expanded in the new version; both new and original parameters are deseribed in Sec. 4.1. Input of titles has not changed, but information concerning titles is repeated in Sec. 4.2. NWAREA is a new NAMELIST described in Sec. 4.3. Instructions on use of the FORTRAN NA.MELIST are provided in Sec. 4.1 of the MILDOS user's manual (Strenge and Bander 1981) or in an IBM FORTRAN reference manual.

\subsection{NAMELIST INDATA}

The MILDOS-AREA parameters provided through NAMELIST INDATA can be classified as shown in Table 4.1. The parameters in each category are described in the following subsections, with emphasis on the new parameters added to MILDOS-AREA.

TABLE 4.1 Classification of MILDOS-AREA Parameters Provided through NAMELIST INDATA

\begin{tabular}{ll}
\hline \multicolumn{1}{c}{ Data Category } & INDATA Parameters ${ }^{2}$ \\
Job control & IFTODO, IRTYPE, JC \\
Source terms & $\begin{array}{l}\text { FRADON, IPACT, NSORCE, } \\
\text { PACT, QAJUST, SORCE, } \\
\text { FAS*, SRNS*, HDP*, PTSZ*, } \\
\text { PTSZFC*, IPSOL* }\end{array}$ \\
Meteorology & FREQ, DMM*, DMA*, \\
Food-pathway parameters & FFORI, FFORP, FHAYI, \\
FHAYP, FPR & IPOP, PAJUST \\
Individual receptnrs & IADD, XRECEP \\
Time history & NSTEP, TSTART, TSTEP \\
\hline
\end{tabular}

$a_{\text {New }}$ parameters are marked with an asterisk $(*)$. 


\subsubsection{Job-Control Parameters}

The three job-control arrays used by MILDOS-AREA are described in Table 4.2. If any element of the array IRTYPE is set to $10, \mathrm{JC}(7)$ must be set to 1 . When $\mathrm{JC}(4)=1$, doses are printed for the pathways and organs listed in Table 4.3. The grid system for population doses is shown in Fig. 4.1.

\subsubsection{Source-Term Parameters}

Table 4.4 describes the original and the new source-term parameters. The three new parameters are listed at the end of the table. Either the SRNS array or SORCE $(9, j)$ must be set by the user so that a release rate is always specified for $\mathrm{Rn}-222$.

The array IPACT has no default values, so the values must be given explicitly by the user. Certain source parameters initialized to 0 , such as NSORCE, also must be assigned values by the user, because the default values are not valid or sensible.

The maximum number of area sources has been reduced from 20 to 10 . This change is reflected in the dimensions of SORCE, IPACT, and QAJUST.

The user can select to use the virtual-point-source method for an area source by setting $\operatorname{SORCE}(10, \mathrm{j})<5000$. This option is useful in the case where source and receptor heights differ significantly, thus violating the assumption of flatness inherent in the finite-element integration method.

A virtual-point area source or a finite element should be no larger in size than $s^{2}$, where: $s=2 x \tan (\pi / 16)$, and $x$ is the distance between the closest receptor and the center of the source or element. Larger areas should be subdivided accordingly.

$\bar{I}$ igure 4.2 shows the locations of reference radon releases represented by the elements of FRADON. The characteristics of particle-size distributions for determining the appropriate value at which to set $\operatorname{SORCE}(11, \mathrm{j})$ are summarized in Table 4.5.

\subsubsection{Meteorological Parameters}

The FREQ array and two mixing heights (DMM, DMA) constitute the usersupplied meteorological parameters, as shown in Table 4.6. The values of DMM and DMA must be specified by the user, because there are no defaults for these parameters.

The wind data should be taken at a reference height of no greater than $10 \mathrm{~m}$ for the tailings application. If the available data are for a much higher reference height, a conversion must be made using an appropriate (power or logarithmic) formula. (The wind-erosion routine, TAILPS, assumes a reference height of $1 \mathrm{~m}$.) 
TABLE 4.2 Job-Control Parameters ${ }^{\mathbf{a}}$
Parameter
(dimension)
Type
Description

IrTODO(10) Integer This array controls calculation and printing of doses for each of NSTEP time steps. When IFTODO(i) $=1$, doses will be calculated and printed for time step i. Default: IETODO(i) $=0$.

IRTYPE(48) Integer This array of control integers is used to specify the output reports requested for each of the IADD locations. For a given receptor location i:

IRTYPE (i) < 0, suppresses printing.

$\operatorname{IRTYPE}(i)=0$, performs a 10 CER 20 check on air concentrations and print a report.

IRTYPE $(i)=i$, prints doses totaled over all exposure pathways.

IRTYPE(i) $=10$, prints doses for each exposure pathway and total doses.

If IRTYPE(i) has any positive value other than 0,1 , or 10 , a default value of $l$ is used. If no value is specified, IRTYPE is set at -1 to suppress printing. When IRTYPE(i) is set at 1 or 10 , reports are printed for total dose commitments and for 40 CFR 190 dose commitments.

JC(10) Integer This job-control-integer array is used to select options for the current calculation. An option is selected by setting the appropriate value to 1. Default: $J C(i)=0$. Use is described below.

$J C(1)=1$, uses the internal windblown dusting-rate algorithm (subroutine TAILPS) in calculating all sources $j$ having $\operatorname{SORCE}(10, j)$ greater than or equal to 2,000 . If $J C(1)=0$, then default dusting values are used for sources with $\operatorname{SORCE}(10, j) \geq 2,000$.

$\mathrm{JC}(2)=1$, computes the 100-year environmental-dose commitments. If $\mathrm{JC}(2)=0$, the annual population-dose comitments are computed.

$\mathrm{JC}(3)=1$, prints total air çoncentrations $\left(\mathrm{pCi} / \mathrm{m}^{3}\right)$, ground concentrations $\left(\mathrm{pCi} / \mathrm{m}^{3}\right)$, and total deposition rates ( $\mathrm{pCi} /\left[\mathrm{m}^{2} \cdot \mathrm{s}\right]$ ) Eor each spatial interval (see $\mathrm{Fig}$. 4.1). 
TABLE 4.2 (Cont'd)

Parameter (dimension)
Type
Description
$\operatorname{JC}(10)$

(Cont'd)
$\mathrm{JC}(4)=1$, prints annual population doses for each spatial intervai. Reports are printed for each pathway and organ listed in Table 4.3. If $\operatorname{JC}(4)=0$, then only a summary table is printed for the population within $80 \mathrm{~km}$ and the extraregional population.

$J C(5)=1$, prints the normalized dispersion-factor $(x / Q)$ arrays. The outputs include the air concentration normalized by the release rate of U-238 for each source, receptor, and particle size and for Rn-222 and six daughters for each source and receptor. The units are:

$$
\frac{\mathrm{pCi} / \mathrm{m}^{3} \text { (air concentration) }}{\mathrm{pCi} / \mathrm{s} \text { (release rate) }}
$$

This option will generate lengthy output when several sources and receptor locations are specified.

$J C(6)=1$, prints a table of dose conversion factors for various pathways, organs, and isotopes. Other information printed includes particle sizes, density, age groups, environmental concentration factors, and time-step-dependent variables.

$\mathrm{JC}(7)=1$, prints total dose commitments (mrem/yr) and 40 CFR 190 dose commitments by age group, pathway, and organ for each receptor location and time step. If $\operatorname{JC}(7) \neq 1$, the pathway data are not printed, and only total dose commitments are printed for each location. This parameter overrides report requests made through the parameter IRTYPE(i). If a full dose printout for any location is desired, $\mathrm{JC}(7)$ must be set at 1 .

$\mathrm{JC}(8)=1$, includes the milk pathway in the calculation of doses at receptor locations. If $\mathrm{JC}(8) \neq 1$, the milk pathway is not included or printed. 


\section{TABLE 4.2 (Cont'd)}

Parameter

(dimension) Type

Description

$\operatorname{JC}(10)$

(Cont'd)
$J C(9)=1$, prints particulate concentrations for air $\left(\mathrm{pCi} /{ }^{3}\right)$ and ground $\left(\mathrm{pCi} / \mathrm{m}^{2}\right)$ at each receptor location. Also printed are particle-size data for particulates ( $\mathrm{U}-238$, Th-230, $\mathrm{Ra}-226$, and $\mathrm{Pb}-210)$, concentrations of radon and daughters ( $R n-222$, Po-218, $\mathrm{Pb}-214, \mathrm{Bi}-214, \mathrm{~Pb}-210, \mathrm{Bi}-210$, and $\mathrm{Po}-210)$, and ground concentrations from radon daughters (Po-218, $\mathrm{Pb}-214, \mathrm{Bi}-214$, and $\mathrm{Pb}-210)$.

$\mathrm{JC}(10)$, not currently in use.

Source: Modified from Strenge and Bander 1981.

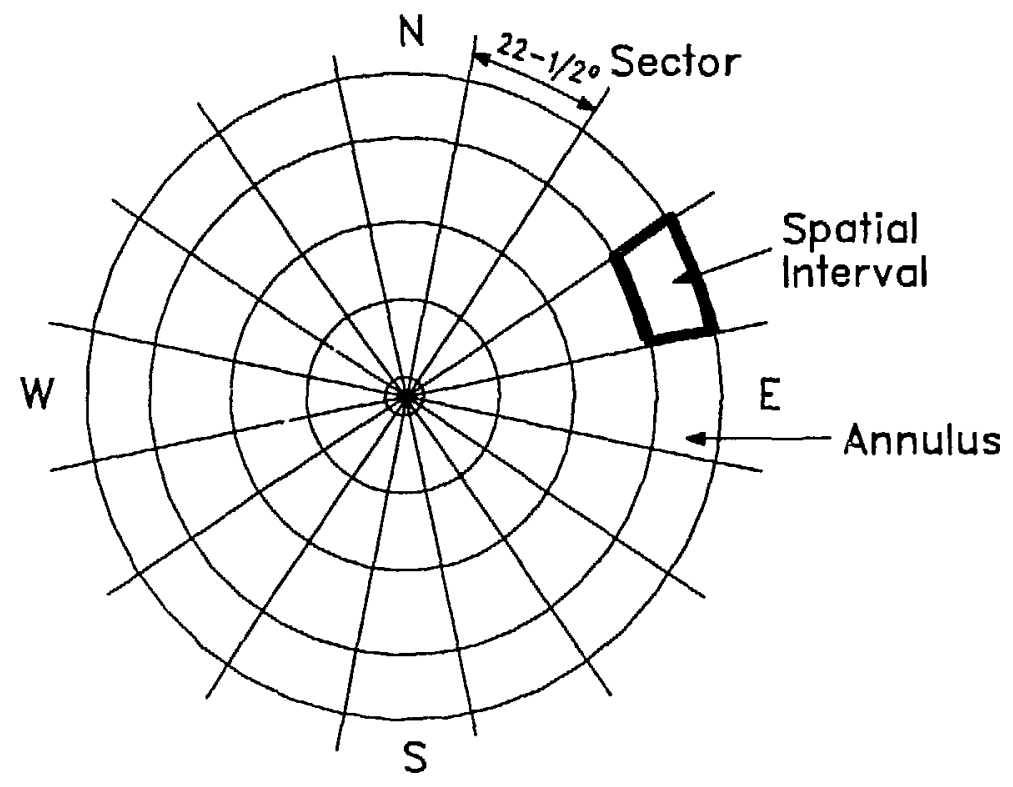

(Facility at Center of Grid)

FIGURE 4.1 Population-Dose Grid-System Definition (Source: Modified from Strenge and Bander 1981) 
TABLE 4.3 Population-Dose Outputs for JC(4) $=1$

\begin{tabular}{|c|c|}
\hline Exposure Pathway & Dose of Interest \\
\hline Inhalation & $\begin{array}{l}\text { Effective dose equivalent } \\
\text { Bone } \\
\text { Mass average lung } \\
\text { Bronchial epithelium }\end{array}$ \\
\hline Ground exposure ${ }^{a}$ & Effective dose equivalent \\
\hline Cloud exposure & Effective dose equivalent \\
\hline Vegetable ingestion & $\begin{array}{l}\text { Effective dose equivalent } \\
\text { Bone }\end{array}$ \\
\hline Meat ingestion & $\begin{array}{l}\text { Effective dose equivalent } \\
\text { Bone }\end{array}$ \\
\hline Milk ingestion & $\begin{array}{l}\text { Effective dose equivalent } \\
\text { Bone }\end{array}$ \\
\hline
\end{tabular}

TABLE 4.4 Source-Term Parameters

Parameter
(dimension) Type Description

FRADON(4) Real The fraction of radon releases attributable to each of the following sites:

FRADON(1) - Casper, Wyo.

FRADON(2) - Falls City, Texas

FRADON(3) - Grants, N.M.

FRADON(4) - Wellpinit, Wash.

Each value must be between 0 and 1 , and the four values must sum to exactly 1 . This array is used to determine impact to populations outside the $80-\mathrm{km}$ radius. See Fig. 4.2 for the locations of these sites. Default: FradoN(i) $=0.0$. 
TABLE 4.4 (Cont'd)

\begin{tabular}{|c|c|c|}
\hline $\begin{array}{l}\text { Parameter } \\
\text { (dimension) }\end{array}$ & Type & Description \\
\hline $\operatorname{IPACT}(10)$ & Integer & $\begin{array}{l}\text { This array assigns mixes defined by } \operatorname{PACT}(i, k) \text { to each } \\
\text { area source } j \text {. A value of IPACT }(j)=i \text { causes mix } i \\
\text { to be used for material in area source } j \text {. IPACT must } \\
\text { have nonnegative integer values } \leq 3 \text {. }\end{array}$ \\
\hline NSORCE & Integer & $\begin{array}{l}\text { The number of effluent sources to be defined for the } \\
\text { current case. } 1 \leq \mathrm{NSORCE} \leq 10 \text { (maximum). }\end{array}$ \\
\hline $\operatorname{PACT}(3,4)$ & Real & $\begin{array}{l}\text { Defines up to three isotopic-composition mixes for } \\
\text { characterizing area-source particulate releases. The } \\
\text { values given for PACT(i,k) represent the specific } \\
\text { activity ( } \mathrm{pCi} / \mathrm{g} \text { ) for radionuclide } k \text { in mix } \mathrm{i} \text {, where: } \\
\quad k=1 \text { for } U-238 \\
k=2 \text { for } \mathrm{Th}-230 \\
k=3 \text { for } \mathrm{Ra}-226 \\
k=4 \text { for } \mathrm{Pb}-210 \\
\text { Default: } \operatorname{PACT}(i, k)=0.0 \text {. }\end{array}$ \\
\hline $\begin{array}{l}\text { QAJUST } \\
(10,2,10)\end{array}$ & Real & $\begin{array}{l}\text { Provides adjustment factors for particulate and radon } \\
\text { emissions for each source and time step. Use is as } \\
\text { follows: QAJUST( } i, 1, j) \text {, adjustment factor for the } \\
\text { particulate activities defined for source } j \text { that are } \\
\text { released during time step i; QAJUST ( } i, 2, j) \text {, adjust- } \\
\text { ment factor for radon activity defined for source } j \\
\text { that is released during time step } i \text {. Default: } \\
\text { QAJUST }(i, k, j)=0.0 \text {. }\end{array}$ \\
\hline \multirow[t]{4}{*}{$\begin{array}{l}\text { SORCE } \\
(12,10)\end{array}$} & Real & $\begin{aligned} & \text { Data defined for each effluent source term } j: \\
& \operatorname{sORCE}(1, j)= x \text { coordinate }(\mathrm{km}) \text { for source } j \text {. A } \\
& \text { positiv value indicates east and a } \\
& \text { negative value indicates west of the } \\
& \text { facility center. }\end{aligned}$ \\
\hline & & $\begin{aligned} \operatorname{SORCE}(2, j)= & y \text { coordinate }(\mathrm{km}) \text { for source } \mathrm{j} \text {. A } \\
& \text { positive value indicates north and a } \\
& \text { negative value indicates south of the } \\
& \text { facility center. }\end{aligned}$ \\
\hline & & $\begin{aligned} \operatorname{SORCE}(3, j)= & \text { elevation }(\mathrm{m}) \text { of source } \mathrm{j} \text {. A positive } \\
& \text { value indicates above and a negative } \\
& \text { value indicates below the elevation of } \\
& \text { the facility center. }\end{aligned}$ \\
\hline & & $\begin{aligned} \operatorname{SORCE}(4, j)= & \text { area }\left(\mathrm{km}^{2}\right) \text { of source } j . \text { A value of } 0 \\
& \text { should be used for point sources, such } \\
& \text { as stacks. }\end{aligned}$ \\
\hline
\end{tabular}


Parameter

(dimension)

SORCE

$(\mathrm{i} 0,12)$

(Cont'd)

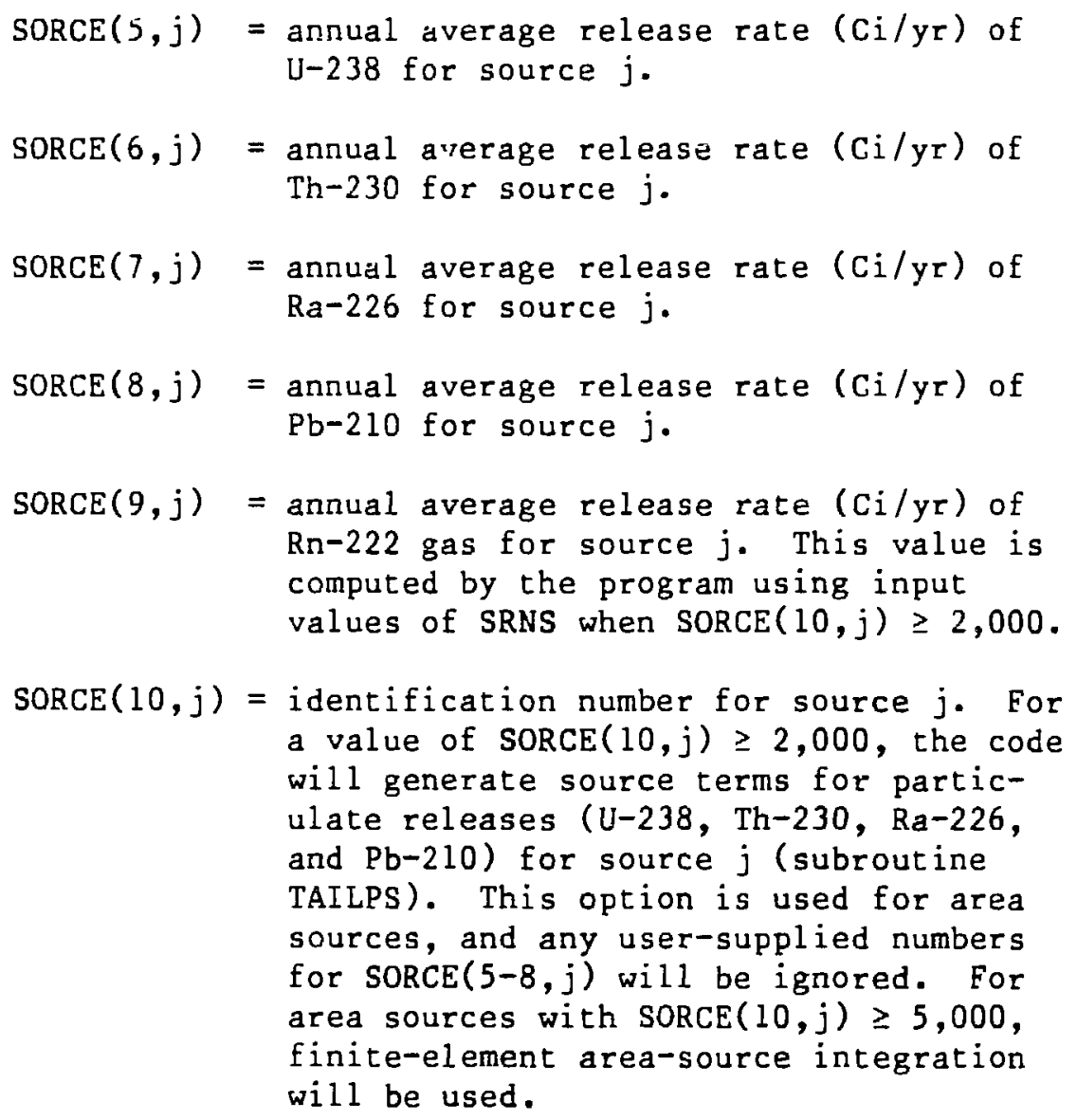
a value of $\operatorname{SORCE}(10, j) \geq 2,000$, the code will generate source terms for particulate releases ( $U-238, \mathrm{Th}-230, \mathrm{Ra}-226$, and $\mathrm{Pb}-210$ ) for source $\mathrm{j}$ (subroutine TAILPS). This option is used for area sources, and any user-supplied numbers for $\operatorname{SORCE}(5-8, j)$ will be ignored. For area sources with $\operatorname{SORCE}(10, j) \geq 5,000$, finite-element area-source integration will be used.

$\operatorname{SORCE}(11, j)=$ assigned particle-size distribution-set number for source $j$. The valid values are 1,2 , or 3 . Table 4.5 summarizes the characteristics of each particlesise distribution.

$\operatorname{SORCE}(12, j)=$ product of stack inside diameter (m) and effluent exit velocity $(\mathrm{m} / \mathrm{s})$ for source $\mathrm{j}, \mathrm{m}^{2} / \mathrm{s}$. Area sources should have $\operatorname{SORCE}(12, j)$ set to 0 .

All default values for SORCE array are 0.0 . 
TABLE 4.4 (Cont'd)

Parameter
(dimension) Type Description

FAS (3) Real

Defines up to three fixed particulate-release rates [corresponding to the three isotopic-composition mixes $\operatorname{PACT}(i, k)]$ for characterizing area-source particulate releases $\left(\mathrm{g} / \mathrm{m}^{2} \cdot \mathrm{s}\right)$. Used along with PACT to compute $\operatorname{SORCE}(5-8, j)$. FAS $(i)<0.0$ and $\operatorname{SORCE}(10, j) \geq 2,000$ cause the code to generate wind-erosion source terms for particulate releases. Default: $F A S(i)=-1$.

SRNS(3) Real Defines up to three radon-release rates for characterizing area-source radon releases $\left(\mathrm{pCi} / \mathrm{m}^{2} \cdot \mathrm{s}\right)$. Used to compute $\operatorname{SORCE}(9, j)$. Default: $\operatorname{SRNS}(i)=0$.

HDP Real If source height ( $m$ ) is below this value, program uses Martin-Tickvart $\sigma_{z}$ values; otherwise, Briggs coefficients are used. ${ }^{2}$ Default: HDP $=50$.

LOGLNR Integer

Defines the option for calculating air concentration in radial direction.

LOGLNR = 1 for logarithmic approximately (Eq. 13b).

LOGLNR $=2$ for linear approximation (Eq. 13c).

Default: $\quad$ LOGLNR $=1$.

PTSZ (5) Real Defines up to four AMADs ( $\mu \mathrm{m}$ ) for AMAD distribution set. Default values are $1.5,3.0,7.7$ and $54 \mu \mathrm{m}$. PTSZ(5) is reserved for radon-daughter-attached aerosol, $0.3 \mu \mathrm{m}$.

$\operatorname{PTSZFC}(4,3)$ Real Defines AMAD distribution for up to four AMADs and three distribution sets. Defaults: $0,1.0,0,0$; $1.0,0,0,0$; and $0,0,0.3,0.7$.

IPSOL(7) Integer Defines solubility classes for radioisotopes. Defaults: $3,3,3,2,2,2,2$.

Source: Modified from Strenge and Bander 1981. 


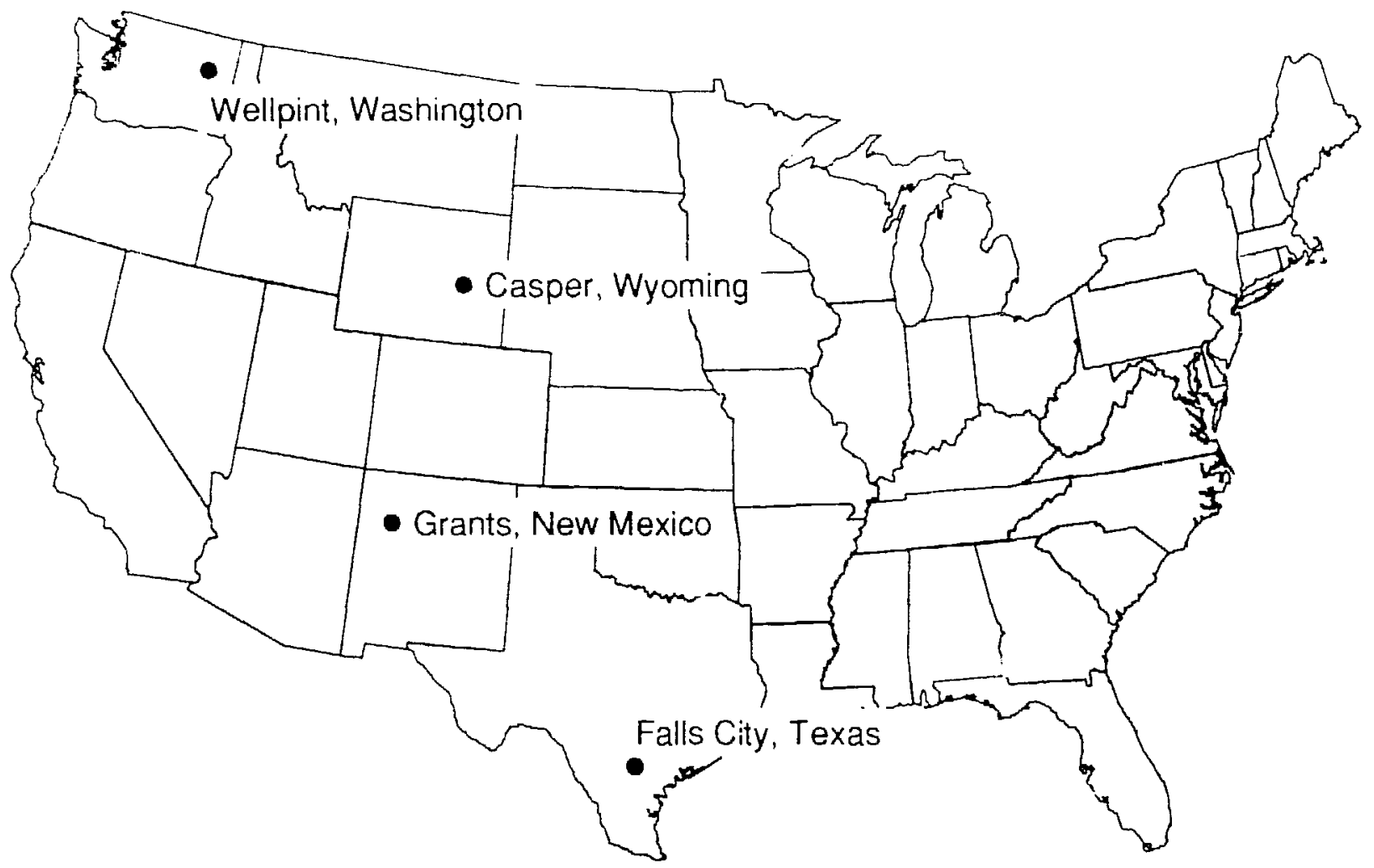

FIGURE 4.2 Geographical Locations of Reference Radon-Release Sites for Continental Population Doses (Source: Modified from Strenge and Bander 1981)

TABLE 4.5 AMAD Distribution-Set Characteristics

\begin{tabular}{|c|c|c|c|c|c|}
\hline $\begin{array}{c}\text { Set } \\
\text { Number }\end{array}$ & $\begin{array}{l}\text { Densiţy } \\
\left(\mathrm{g} / \mathrm{cm}^{3}\right)\end{array}$ & $\begin{array}{l}\text { Particle } \\
\text { Size } \\
\quad(u \mathrm{~m})\end{array}$ & $\begin{array}{l}\mathrm{AMAD} \\
(2 \pi)\end{array}$ & $\begin{array}{l}\text { Percentage } \\
\text { of Material }\end{array}$ & Source Types \\
\hline 1 & 8.9 & 1 & 3 & 100 & $\begin{array}{l}\text { Yellowcake dryer packaging } \\
\text { or equivalent }\end{array}$ \\
\hline 2 & 2.4 & 1 & 1.5 & 100 & $\begin{array}{l}\text { Crushers, grinders, rod } \\
\text { mills, conveyers, fine-ore } \\
\text { blending, and other mill- } \\
\text { process sources }\end{array}$ \\
\hline 3 & $\begin{array}{l}2.4 \\
2.4\end{array}$ & $\begin{array}{r}5 \\
-5\end{array}$ & $\begin{array}{l}7.7 \\
54\end{array}$ & $\begin{array}{l}30 \\
70\end{array}$ & Tailings, ore-storage piles \\
\hline
\end{tabular}

Source: Modified from Strenge and Bander 1981. 


\section{TABLE 4.6 Meteorological Parameters}

\begin{tabular}{lll}
$\begin{array}{l}\text { Parameter } \\
\text { (dimensions) }\end{array}$ & Type & Description \\
\hline FREQ $(16,6,6)$ & Real & $\begin{array}{l}\text { Fractional joint frequency of occurrence of wind } \\
\text { direction }(16), \text { windsped class }(6) \text { and atmospheric } \\
\text { stability class }(6), \text { dimensionless. }\end{array}$ \\
& FREQ $(i, j, k) \geq 0, \sum_{i, j, k}$ FREQ $(i, j, k)=1.00$ \\
DMM, DMA & Real Annual average morning and afternoon mixing heights \\
& & $(m) . b$
\end{tabular}

avalues should be derived from data taken at a height of $10 \mathrm{~m}$ or less (see Sec. 4.1.3).

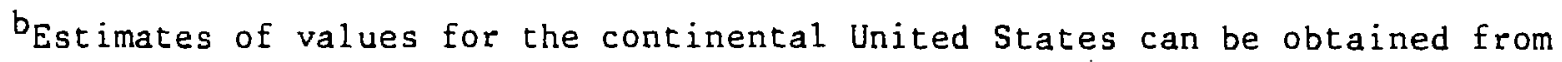
Holzworth 1972 .

Source: Modified from Strenge and Bander 1981.

\subsubsection{Remaining INDATA Parameters}

The remaining data categories in NAMELIST INDATA are described in Tables 4.7-4.12. Table 4.7 explains the food-pathway parameters, and Table 4.8 gives suggested values of food-production rates in each state. Table 4.9 explains the population-distribution parameters, and Table 4.10 gives the projected U.S. population to the year 2050. Ratios of PAJUST can be determined from the data of Table 4.10. Tables 4.11 and 4.12 explain the parameters in the categories of individual receptors and time history, respectively.

The default values for the array PAJUST (1.0) imply constant population with respect to the base year (1980) and must be overridden by the user to more realistically represent U.S. demography. IADD and NSTEP have invalid defaults of 0 , and must be set by the user. TSTART has no default, and also must be specified by the user.

\subsection{TITLE CARDS}

Immediately after the card that signals the end of INDATA, the title cards follow in the exact order and quantity shown in Table 4.13. The order of the source, receptor, and time-step labels must correspond to the order of definition for arrays SORCE, XRECEP, and TSTEP, respectively. Labels that exceed the allowed length are truncated. 
TABLE 4.7 Food-Pathway Parameters

\begin{tabular}{|c|c|c|}
\hline $\begin{array}{l}\text { Parameter } \\
\text { (dimension) }\end{array}$ & Type & Description \\
\hline FFOR I & Real & $\begin{array}{l}\text { Fraction of total annual livestock feed requirements } \\
\text { assumed to be satisfied by pasture grass, used for } \\
\text { calculating individual doses. Default value is } 0.5 \text {. }\end{array}$ \\
\hline FEORP & Real & $\begin{array}{l}\text { Fraction of total annual } 1 \text { ivestock feed requirements } \\
\text { assumed to be satisfied by pasture grass, used for } \\
\text { calculating population doses. Default value is } 0.5 \text {. }\end{array}$ \\
\hline EHAYI & Real & $\begin{array}{l}\text { Fraction of total annual livestock feed requirements } \\
\text { assumed to be satisfied by locally grown stored feed, } \\
\text { used for calculating individual doses. Default value is } \\
0.5 \text {. }\end{array}$ \\
\hline FHAYP & Real & $\begin{array}{l}\text { Fraction of total annual livestock feed requirements } \\
\text { assumed to be satisfied by locally grown stored feed, } \\
\text { used for calculating population doses. Default value is } \\
0.5 \text {. }\end{array}$ \\
\hline $\mathrm{FPR}(3)$ & Real & $\begin{array}{l}\text { Areal food-production rate in } \mathrm{kg} /\left(\mathrm{yr} \cdot \mathrm{km}^{2}\right) \text { for }(1) \text { vege- } \\
\text { tables, (2) meat, and ( } 3) \mathrm{milk} \text { in the region around the } \\
\text { facility. Suggested values are given in Table } 4.8 \text {. } \\
\text { Default: FPR(i) }=0.0 \text {. }\end{array}$ \\
\hline
\end{tabular}

Source: Modified from Strenge and Bander 1981.

\subsection{NAMELIST NWAREA}

For each area source for which IPACT(j) $\neq 0$ (i.e., for which a particulate mix is specified), a subset of the parameters listed in Table 4.14 must be provided in a separate NWAREA NAMELIST. In each such NAMELIST, NEX is always specified. If NEX $\neq 0$ (an automeshing option for a quadrilateral area), then NEY and VERTEX must also bc specified, and the remaining parameters skipped. If $\mathrm{NEX}=0$ (an option for any shaped area), then NAS, NODE, NNODE, XS, and YS are specified, and NEY and VERTEX are skipped.

The subset consisting of NEX, NEY, and VERTEX is used in the program to assign node numbers and coordinates automatically in the case of a quadrilaterally shaped source. For an irregularly shaped source, the node numbers and coordinates must be specified by the user. The node-number sequence proceeds from bottom to top, left to right, as shown in Fig. 4.3. This order is consistent with the vertex-number sequence in the large quadrilateral area source (Fig. 2.3). Appendix C presents sample problems illustrating both automatic and manual node numbering. 
TABLE 4.8 Average Annual Agricultural Productivity by State

\begin{tabular}{|c|c|c|c|c|c|c|}
\hline \multirow[b]{2}{*}{ State } & \multicolumn{6}{|c|}{ Average Productivity $\left(\mathrm{kg} / \mathrm{yt} \cdot \mathrm{km}^{2}\right)$} \\
\hline & \multicolumn{2}{|c|}{ Crops } & \multicolumn{2}{|c|}{ Meat } & \multicolumn{2}{|c|}{ Dairy } \\
\hline Al abama & 5.53 & $E+03$ & 2.26 & $E+03$ & 6.28 & $E+02$ \\
\hline Alaska & 2.49 & $E-02$ & 3.49 & $E-03$ & 1.69 & $E-02$ \\
\hline Arizona & 2.16 & $E+03$ & 3.31 & $\mathrm{E}+02$ & 9.64 & $E+02$ \\
\hline Arkansas & 1.58 & $E+04$ & 4.31 & $E+03$ & 1.23 & $E+03$ \\
\hline California & 1.38 & $E+04$ & 1.09 & $\mathrm{E}+03$ & 5.23 & $E+03$ \\
\hline Colorado & 1.27 & $E+04$ & 1.13 & $E+03$ & $8.3 !$ & $E+02$ \\
\hline Connecticut & 6.19 & $E+02$ & 8.48 & $E+02$ & 3.29 & $E+03$ \\
\hline Delaware & 7.70 & $E+04$ & 2.64 & $E+04$ & 6.58 & $E+03$ \\
\hline Florida & 2.20 & $E+04$ & 1.28 & $E+03$ & 2.52 & $E+63$ \\
\hline Georgia & 1.04 & $E+04$ & 2.93 & $E+03$ & 1.41 & $E+03$ \\
\hline Hawai i & 1.61 & $E+03$ & 1.02 & $E+03$ & 1.87 & $E+03$ \\
\hline Idaho & 1.42 & $E+04$ & 3.21 & $E+02$ & 1.26 & $E+03$ \\
\hline Illinois & 2.66 & $E+05$ & 5.41 & $E+03$ & 6.75 & $E+03$ \\
\hline Indiana & 1.80 & $E+05$ & 7.12 & $E+03$ & 8.07 & $E \nrightarrow 03$ \\
\hline Iowa & 2.89 & $E+05$ & 1.59 & $E+04$ & 1.14 & $E+04$ \\
\hline Kansas & 8.45 & $E+04$ & 5.40 & $E+03$ & 2.61 & $E+03$ \\
\hline Kentu & 2.82 & $E+04$ & 1.75 & $E+03$ & 5.82 & $E+03$ \\
\hline Louisiana & 6.79 & $E+03$ & 6.19 & $E+02$ & 1.20 & $E+03$ \\
\hline Maine & 1.12 & $E+03$ & 1.20 & $E+02$ & 3.04 & $E+02$ \\
\hline Maryland & 3.57 & $E+04$ & 6.48 & $E+03$ & 1.14 & $E+04$ \\
\hline Massachusetts & 5.55 & $E+02$ & 1.91 & $E+02$ & 1.64 & $E+03$ \\
\hline Michigan & 2.35 & $E+04$ & 6.72 & $E+02$ & 4.85 & $E+03$ \\
\hline Minnesota & 7.93 & $E+04$ & 3.17 & $E+03$ & 1.24 & $E+04$ \\
\hline Mississippi & 1.11 & $E+04$ & 1.91 & $E+03$ & 1.37 & $E+03$ \\
\hline Missouri & 4.48 & $E+04$ & 3.68 & $E+03$ & 4.89 & $E+03$ \\
\hline Montana & 1.20 & $E+04$ & 5.46 & $E+02$ & 2.67 & $E+02$ \\
\hline Nebraska & 1.20 & $E+05$ & 6.89 & $E+03$ & 2.81 & $E+03$ \\
\hline Nevada & 1.47 & $E+02$ & 2.25 & $E+01$ & 5.09 & $E+01$ \\
\hline New Hampshire & 8.53 & $E+01$ & 5.44 & $E+01$ & 5.83 & $E+02$ \\
\hline New Jersey & 6.21 & $E+03$ & 3.05 & $E+02$ & 2.22 & $E+03$ \\
\hline New Mexico & 1.58 & $E+03$ & 4.00 & $E+02$ & 7.10 & $E+02$ \\
\hline New York & 8.24 & $E+03$ & 6.26 & $E+02$ & 1.24 & $E+04$ \\
\hline North Carolin & 1.53 & $E+04$ & 3.14 & $E+03$ & 1.99 & $E+03$ \\
\hline North Dakota & 8.37 & $E+04$ & $\therefore .04$ & $E+03$ & 2.34 & $E+03$ \\
\hline Ohio & 8.72 & $E+04$ & 3.26 & $E+03$ & 1.14 & $E+04$ \\
\hline Oklahoma & 2.29 & $E+04$ & 2.85 & $E+03$ & 2.19 & $E+03$ \\
\hline Oregon & 4.22 & $E+03$ & 2.64 & $E+02$ & 6.82 & $E+02$ \\
\hline Pennsyl var & 1.04 & $E+04$ & 1.77 & $E+03$ & 1.04 & $E+04$ \\
\hline Rhode Island & 1.19 & $E+03$ & 1.92 & $E+02$ & 7.10 & $E+02$ \\
\hline
\end{tabular}


TABLE 4.8 (Cont'd)

\begin{tabular}{|c|c|c|c|}
\hline \multirow[b]{2}{*}{ State } & \multicolumn{3}{|c|}{ Average Productivity $\left(\mathrm{kg} / \mathrm{yr} \cdot \mathrm{km}^{2}\right)$} \\
\hline & Crops & Meat & Dairy \\
\hline South Carolina & $8.03 E+03$ & $9.30 \quad E+02$ & $9.50 \quad E+02$ \\
\hline South Dakota & $4.54 E+04$ & $2.89 E+03$ & $3.66 E+03$ \\
\hline Tennessee & $1.59 E+04$ & $1.76 \mathrm{E}+03$ & $4.69 E+03$ \\
\hline Texas & $1.71 E+04$ & $2.55 E+03$ & $1.98 E+03$ \\
\hline Utah & $4.94 E+02$ & $1.06 \quad E+02$ & $4.61 \mathrm{E}+02$ \\
\hline Vermont & $6.58 E+02$ & $3.36 \mathrm{E}+02$ & $1.19 \mathrm{E}+04$ \\
\hline Virginia & $1.02 E+04$ & $1.71 E+03$ & $3.37 E+03$ \\
\hline Washington & $1.99 \mathrm{E}+04$ & $6.62 \mathrm{E}+02$ & $3.28 E+03$ \\
\hline West Virginia & $1.25 E+03$ & $3.74 E+02$ & $5.85 E+02$ \\
\hline Wisconsin & $3.73 E+04$ & $2.08 E+03$ & $3.70 \quad E+04$ \\
\hline Wyoming & $3.12 E+03$ & $3.45 E+02$ & $1.34 E+02$ \\
\hline U.S. Total & $2.43 \mathrm{E}+04$ & $1.34 \mathrm{E}+03$ & $2.92 E+03$ \\
\hline
\end{tabular}

Source: Based on data from U.S. Bureau of the Census 1984.

TABLE 4.9 Population-Distribution Parameters

Parameter
(dimensions) Type Description

$\begin{array}{ll}\text { IPOP }(12,16) \quad \text { Integer } & \begin{array}{l}\text { Population-distribution data IPOP }(i, j) \text { gives the } \\ \text { population in the spatial interval defined by the } \\ \\ \text { ith distance interval and the jth direction, where }\end{array} \\ & j=1 \text { indicates north. Default: IPOP }(i, j)=0 . \\ \text { PAJUST(10) Real } & \text { Ratio of the U.S. population during each time step } \\ & \text { to that during the base year (1980). A value must } \\ & \text { be given for each of the NSTEP time steps in } \\ & \text { order. These values are used to obtain the proper } \\ & \text { continental population doses as a function of the } \\ & \text { time of exposure. See Table } 4.10 \text { to determine } \\ & \text { ratios. }\end{array}$

Source: Modified from Strenge and Bander 1981. 
TABLE 4.10 Projected Population of the United States, 1980-2050

\begin{tabular}{|c|c|c|c|}
\hline Year & $\begin{array}{l}\text { Population } \\
\text { (millions) }\end{array}$ & Year & $\begin{array}{l}\text { Population } \\
\text { (millions) }\end{array}$ \\
\hline 1980 & 227.7 & 1992 & 253.9 \\
\hline 1981 & 229.8 & 1993 & 255.9 \\
\hline 1982 & 232.0 & 1994 & 257.8 \\
\hline 1983 & 234.2 & 1995 & 259.6 \\
\hline 1984 & 236.4 & 1996 & 261.4 \\
\hline 1985 & 238.6 & 1997 & 263.1 \\
\hline 1986 & 240.9 & 1998 & 264.8 \\
\hline 1987 & 243.1 & 1999 & 266.4 \\
\hline 1988 & 245.4 & 2000 & 268.0 \\
\hline 1989 & 247.6 & 2025 & 301.0 \\
\hline 1990 & 249.7 & 2050 & 308.9 \\
\hline 1991 & 251.8 & & \\
\hline
\end{tabular}

${ }^{a}$ All data are for midyear.

Source: Modified from U.S. Bureau of the Census 1982. 
TABLE 4.11 Individual Receptor-Location Parameters

\begin{tabular}{|c|c|c|}
\hline $\begin{array}{l}\text { Parameter } \\
\text { (dimensions) }\end{array}$ & Type & Descripcion \\
\hline IADD & Inceger & $\begin{array}{l}\text { This parameter specifies the number of locations for } \\
\text { which individual doses will be calculated: } \\
1 \leq \text { IADD } \leq 48 \text {. }\end{array}$ \\
\hline \multirow[t]{5}{*}{$\operatorname{XRECEP}(3,48)$} & Real & $\begin{array}{l}\text { This array gives coordinates of each receptor } \\
\text { location. For each receptor i, the data are } \\
\text { entered as follows: }\end{array}$ \\
\hline & & $\begin{array}{l}\operatorname{XRECEP}(1, i)-- \text { distance }(\mathrm{km}) \text { to the east (positive } \\
\text { value) or west (negative value) of the facility } \\
\text { center. }\end{array}$ \\
\hline & & $\begin{array}{l}\text { XRECEP( } 2, i)-- \text { distance }(\mathrm{km}) \text { to the north } \\
\text { (positive) or south (negative) of the facility } \\
\text { center. }\end{array}$ \\
\hline & & $\begin{array}{l}\text { XRECEP( } 3, i)-- \text { elevation }(m) \text { of the receptor above } \\
\text { (positive) or below (negative) the elevation of } \\
\text { the facility center. }\end{array}$ \\
\hline & & Default: $\operatorname{XRECEP}(k, i)=0.0$ \\
\hline
\end{tabular}

Source: Modified from Strenge and Bander 1981. 
TABLE 4.12 Time-History Parameters

Parameter

(dimension)

Type

Description

NSTEP

Integer Number of time steps used to define the facility liferime. $1 \leq N S T E P \leq 10$ (maximum).

TSTART Real Year of initial effluent release, in year A.D.

Fractional values (noninteger) are used to account for startup during a year, e.g., 1980.5 would indicate startup at the beginning of July 1980.

TSTEP(10) Real The length of each time step, in number of years. The number of values to be given is equal to NSTEP. A minimum value of 2 years is assumed, i.e., if a smaller value is given it will be set to 2 years. Default: $\operatorname{TSTEP}(\mathrm{i})=5.0$.

Source: Modified from Strenge and Bander 19801.

TABLE 4.13 Order of Title Cards

\begin{tabular}{|c|c|c|c|c|}
\hline $\begin{array}{l}\text { Number } \\
\text { of Cards }\end{array}$ & $\begin{array}{l}\text { Label } \\
\text { Name }\end{array}$ & Columns & Format & Description \\
\hline \multirow[t]{2}{*}{1} & REGION & $1-24$ & A24 & Region identification \\
\hline & METSET & $31-54$ & A24 & $\begin{array}{l}\text { meteorological-data } \\
\text { identification }\end{array}$ \\
\hline NSORCE & QNAME $(j)$ & $1-20$ & $\mathrm{~A} 20$ & Label for source $j$ \\
\hline$I A D D$ & XNAYE $(i)$ & $1-20$ & A20 & $\begin{array}{l}\text { Label for individual } \\
\text { receptor location i }\end{array}$ \\
\hline NSTEP & $\operatorname{TNAME}(k)$ & $1-20$ & $A 20$ & $\begin{array}{l}\text { Time step k } \\
\text { identification label }\end{array}$ \\
\hline
\end{tabular}


TABLE 4.14 Large-Area-Source Parameters

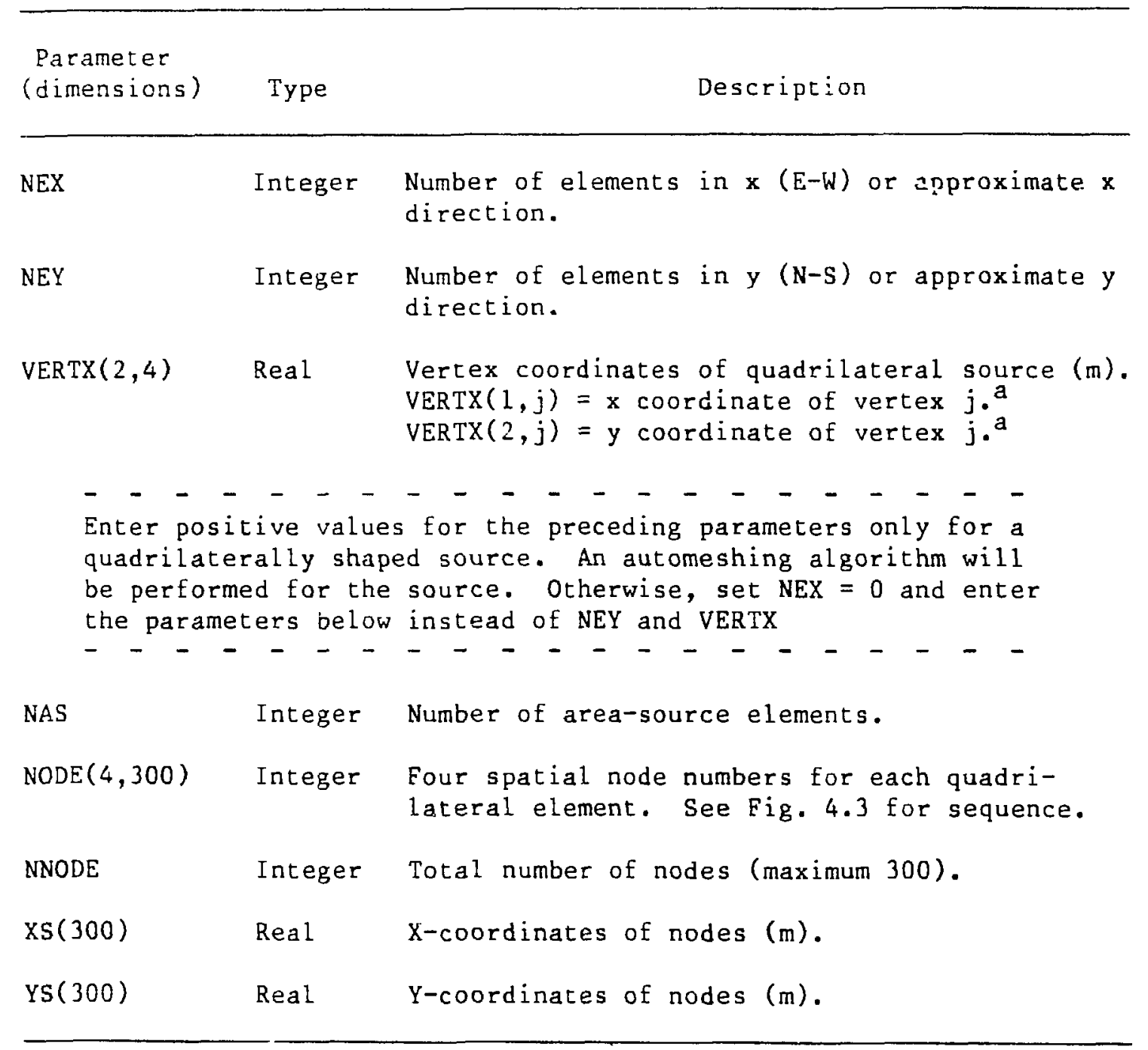

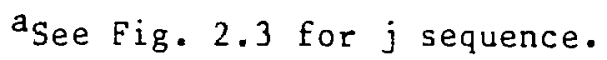
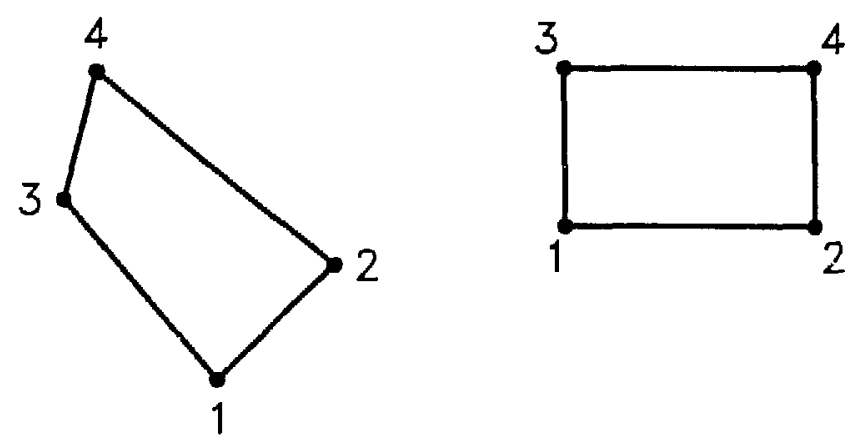

FIGURE 4.3 Node Numbering for Quadrilateral

\section{Elements}




\section{INSTALLATION AND USE OF MILDOS-AREA}

Steps and commands for installation and use of MILDOS-AREA on a personal computer are summarized in the following sections. The MILDOS-AREA code contains a number of calls specific to the Lahey FORTRAN 77 Language System (F77L, Version 3.0). Lahey FORTRAN was used because it currently is the only PC-DOS compiler that supports NAMELIST input.

\subsection{INSTALLING MILDOS-AREA}

An IBM (or compatible) microcomputer with a hard disk drive and approximately $500 \mathrm{~K}$ of memory is required for MLLDOS-AREA. A DOS 3.1 or equivalent operating system, a mathematics coprocessor, and a printer capable of 132-column output are needed. Most PC printers have a condensed print option (17 characters per inch) that is satisfactory.

The code is distributed either on a single $360 \mathrm{~K}, 5.25$-inch or a $1.4 \mathrm{M}, 3.5$-inch diskette. In addition to executable modules, the diskette contains the FORTRAN source code for all MILDOS-AREA programs and three sample problems (SAMPLE.DAT, TESTC1.DAT, TESTC2.DAT) (see Appendix C). The steps for installing the code are as follows:

1. Assuming the hard disk is the $\mathrm{C}$ disk, move to the $\mathrm{C}$ disk drive with the DOS commands:

$$
\begin{aligned}
& \text { C: } \\
& \text { CD } \backslash
\end{aligned}
$$

2. Issue the DOS command:

$$
\text { PROMPT \$P\$G }
$$

This adds the current subdirectory to the DOS prompt.

3. Create a subdirectory called MLLDOS on the hard disk. Move to the new subdirectory using the commands:

MD MILDOS

CD MILDOS

The prompt "C: \MILDOS>" should appear on the monitor. 
4. Insert either distribution diskette into the A disk drive and issue the command:

\section{COPY A:*.*}

to copy all necessary files to the hard disk.

5. In the case of the 5.25-inch diskettes, the MILDOS-AREA system is stored in a special, compacted format to fit onto a single $360 \mathrm{~K}$ diskette. To complete the installation for the 5.25 -inch diskette only, enter the command:

\section{INSTALL}

At this point, all of the executable modules and files needed to run MILDOSAREA will be on the hard disk. However, successful execution of the code will require a CONFIG.SYS file in the root directory of the hard disk that contains at least the following:

FILES $=20$

BUFFERS $=16$

SHELL=C:\COMMAND.COM /P/E:256

A CONFIG.SYS consisting of the above lines will be found in the IMILDOS directory. This may be copied directly by the command:

\section{COPY C:\MILDOS\CONFIG.SYS C:\}

or an existing CONFIG.SYS may be modified with a suitable editor, such as EDLIN. Note that the 256 in the SHELL command sets the size of the DOS environment-string table. If an out-of-memory environment error occurs, increase the size of the E parameter. A system reboot (Ctrl-Alt-Del) is needed whenever changes are made to the CONFIG.SYS file.

\subsection{EXECUTING MILDOS-AREA}

The prompts (in boldface) and responses to start executing MILDOS-AREA are:

$C: \backslash>$ ed $\backslash$ mildos

C:\MILDOS> mildos 
A single optional command line argument, the name of the user-prepared input data file, may also be included. For example:

C:\MILDOS> mildos mysite.dat

If the data file name is not supplied on the command line, the user will be prompted for its input before calculations start. The file name also can contain drive and path information up to a maximum of 24 characters; otherwise, the customary defaults of current drive and directory apply. The data file name is a part of the header on all pages of MILDOS-AREA output.

The actual start of MILDOS-AREA is a banner screen with a brief definition of the code. This is followed by a printer setup series that allows the user to set the printer for 132-column output if desired.

If there was no command line argument, the user will then be prompted to input the run-dependent data file name. If there is a rull input ("Enter" key only), the default file SAMPLE.DAT supplied with the distribution diskette will be used.

The program next echoes the name of the file that it will open for data input. If the file open and data input are successful, a brief series of progress reports will appear on the monitor screen ending with:

MILDOS complete, elapsed time $=$ xxxxx.xxxx seconds.

The user can abort a run at any prior to the above completion message with a Ctrl-Break (hold down Ctrl key and press Break key). However, execution probably will not stop immediately.

\subsection{VIEWING OUTPUT}

Instead of providing direct printer output, MILDOS-AREA produces a hard disk file named MILDOS.REP. This cutput file is overwritten with every execution of the code. Thus, the user should examine and, if desired, save some or all of the output into a selected disk file before starting a new run.

To provide for easy viewing of MILDOS.REP with optional hard copy and selective saving of the file, the utility program PAGER.EXE is included on the distribution diskette. PAGER is a useful program for viewing any ASCil file, particularly FORTRAN printer files that contain control characters in column 1 of each line.

PAGER, with MILDOS.REP as the input file, is loaded automatically by MILDOS.BAT, the DOS batch file that executes MILDOS-AREA. This occurs as soon as MILMAIN, the MILDOS-AREA FORTRAN module, completes normally. The viewing process starts by displaying the first page of MILDOS.REP. This is a table of contents, and it has been added to the original MILDOS output for user convenience. A typical table of contents is shown with the computer output in Sec. C.3 of Appendix C. 
As soon as PAGER completes reading in the entire file, which is indicated in the status line at the bottom of the screen, any page of MILDOS.REP may be viewed by entering the page number and pressing "Enter" or "F10." On-line help on the use of PAGER, primarily key strokes to aid in the page display, is available at any time by pressing the F1 function key. Function keys F7 and F 8 can be used to produce hard copy and to save selected portions of the output (see Sec. 5.4). Pressing "Esc" exits PAGER and returns the user to the normal DOS prompt. This terminates the MILDOS-AREA run. PAGER can be executed independently by entering PAGER at the DOS prompt. The name of the ASCII file to be viewed can be included as an optional command line argument. For example:

\section{C:\MILDOS> pager mysite.rep}

PAGER will prompt for the name of the file to be viewed if it is omitted from the command line. The independent use of PAGER is a convenient method of retrieving an old MILDOS-AREA run that has been saved. And, of course, MILDOS.REP can be viewed to check the last. MILDOS-AREA output without rerunning the code.

\subsection{PRODUCING HARD COPY AND SAVING SELECTED OUTPUT}

At any time wrile viewing a file via PAGER, hard copy can be produced by pressing the F7 or F8 function keys. The F8 key produces an immediate copy of the current screen page only.

The F7 function key is a more versatile but complicated option. The user is first informed of the current hard copy destination (LPT1 for normal printer or a disk file name) and allowed to make a change, if desired. If an existing disk file is selected, the user can specify to overwrite or append. The following series of options can then be exercised repeatedly (until "Esc"):

- Enter the first and last page numbers, separated by a space or comma, to print (or save). Enter a single page number to print that page only.

- Press "Enter" key only to print current page (current page number will be displayed on screen).

- Press "D" or "d" to print entire document (file).

- Press "P" or "p" to pass ASCII control characters to the printer.

- Press "Esc" to resume normal PAGER viewing of the file.

To preserve an option of an earlier PAGER version, the "*" key is identical to $\mathrm{F} 7$. 


\section{REFERENCES}

Cristy, M., et al., 1986, Relative Age-Specific Radiation Dose Commitment Factors for Major Radionuclides Released from Nuclear Fuel Facilities, Report NUREG/CR-4628, Oak Ridge National Laboratory, Oak Ridge, Tenn., for U.S. Nuclear Regulatory Commission, Washington, D.C.

Eimutis, E.C., and M.G. Konicek, 1971, Derivations of Continuous Functions for the Lateral and Vertical Atmospheric Dispersion Coefficients, Technical Note, Atmospheric Environment, 6:859-863.

Gifford, F.A, 1976, Turbulent Diffusion-Typing Schemes: A Review, Nuclear Safety, $17: 68-86$.

Holzworth, G.C., 1972, Mixing Heights, Wind Speeds, and Potential for Urban Air Pollution Throughout the Contiguous United States, U.S. Environmental Protection Agency Report PB 207 103, Research Triangle Park, N.C.

International Commission on Radiological Protection, 1979, Limits for Intakes of Radionuclides by Workers (adopted July 1978), ICRP Publication 30.

ICRP Task Group on Lung Dynamics, 1966, Deposition and Retention Models for Internal Dosimetry of Human Respiratory Tract, Health Physics, 12:173-207.

Martin, D.O., and J.A. Tickvart, 1968, A General Atmospheric Diffusion Model for Estimating the Effects on Air Quality of One or More Sources, presented at the 61st Annual Meeting of the Air Pollution Control Assoc., St. Paul, Minn.

National Bureau of Standards, 1965, Handbook of Mathematical Functions with Formulas, Graphs, and Mathematical Tables, Applied Mathematics Series 55, Washington, D.C., Dec.

Powell, D.C., H.L. Wegley, and T.D. Fox, 1979, MESODIF-II: A Variable Trajectory Plume Segment Model to Assess Ground-Level Air Concentrations and Deposition of Effluent Releases from Nuclear Power Facilities, Report NUREG/CR-0523, PNL-2419, Pacific Northwest Laboratory, Richland, Wash., for the U.S. Nuclear Regulatory Commission, Washington, D.C.

Strang, G., and G.J. Fix, 1973, An Analysis of the Finite Element Method, Prentice-Hall, Englewood Cliffs, N.J.

Strenge, D.L., and T.J. Bander, 1981, MILDOS - A Computer Program for Calculating Environmental Radiation Doses from Uranium Recovery Operations, Report NUREG/ CR-2011, PNL-3767, Pacific Northwest Laboratory, Richland, Wash., for the U.S. Nuclear Regulatory Commission, Washington, D.C. 
U.S. Bureau of the Census, 1982, Current Population Reports, Series P-25, No. 922, U.S. Department of Commerce, Washington, DC.

U.S. Bureau of the Census, 1984, 1982 Census of Agriculture, Vol. 1, Geographic Series, Part 51, United States Summary and State Data, AC82-A-51, U.S. Department of Commerce, Washington, D.C.

U.S. Environmental Protection Agency, 1978, Workbook for Comparison of Air Quality Models-Appendices, Report EPA-450/2-78-028b, OAQPS No.1.2-097A, Research Triangle Park, N.C.

Yuan, Y.C., 1979, Application of the Finite Element Method to the Calculation of Atmospheric Transport from Large Area Sources, Transactions, American Nuclear Society, 32:108-109. 
$51 / S 2$

APPENDIX A:

PROGRAM STRUCTURE 


\section{APPENDIX A:}

\section{PROGRAM STRUCTURE}

This appendix summarizes information on program structure and data transfer in MILDOS-AREA. Twenty-seven FORTRAN modules (plus block data) constitute the program MILDOS-AREA, an increese of 11 modules over the original MILDOS code. The hierarchy of the modules is described in Sec. A.1, and details of each new module are given in Sec. A.2. Significant changes to preexisting modules are discussed in Sec. A.3.

Also referenced by MILDOS-AREA are five routines specific to the Lahey F77L FORTRAN Language System:

DATE: $\quad$ Returns system date as MM/DD/YY,

GETCL: Returns DOS command line input, i.e., file name of input data,

NBLANK: Returns last nonblank position in a character string,

TIMER: Returns count of 0.01 second ticks since midnight,

UNDERO: Stores zero and suppresses arithmetic underflow error message.

Eleven labeled common blocks provide for most of the data transfer between modules. Two common blocks (DEPY and GDATA) have been eliminated. Four new commcn blocks (AREA, CHAR, DOSINH, and PTDISP) have been added and are described in Sec. A.4.

\section{A.1 HIERARCHY}

The ealling sequence of the new and modified modules is given in Fig. A.1, and corresponding module functions are listed in Table A.1. Modules that are unchanged from the previous version of MILDOS are not shown.

\section{A.2 NEW MODULES}

The new modules in MILDOS are described in alphabetical order. The descriptions include purpose of the module, functions performed, calling routine, argument list, common-block usage, and subordinate modules. 


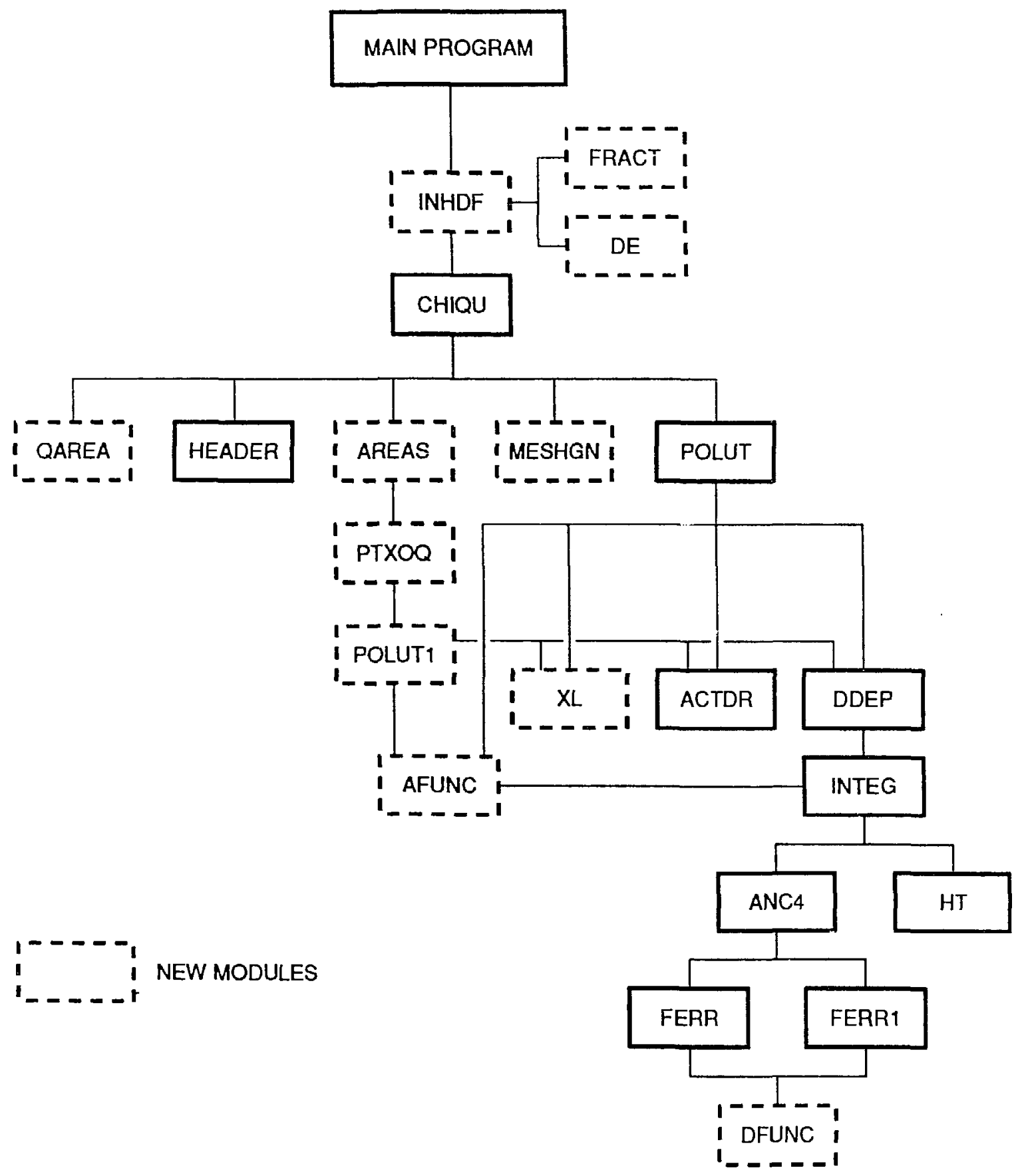

FIGURE A.1 Hierarchy Diagram of New (dashed boxes) and Modified (solid boxes) Modules (functions are listed in Table A.1) (Modified from

Strenge and Bander 1981) 


\section{TABLE A.1 Functions of New and Modified MILDOS Modules ${ }^{8}$}

Module $e^{b} \quad$ Function

\begin{tabular}{|c|c|}
\hline ACTDR & Computes Rn-222 decay and progeny ingrowth \\
\hline AFUNC* & $\begin{array}{l}\text { Computes vertical dispersion coefficient as a } \\
\text { function of downwind distance }\end{array}$ \\
\hline ANC4 & Utility numerical integration routine \\
\hline AREAS* & $\begin{array}{l}\text { Computes air concentrations at each location of } \\
\text { interest due to a large area source }\end{array}$ \\
\hline CHIQU & $\begin{array}{l}\text { Calculates normalized air concentrations } \\
\text { (particulates and gases) for each source }\end{array}$ \\
\hline DDEP & Computes source depletion factors \\
\hline$D E \div$ & Calculates inhalation dose factors \\
\hline DFUNC* & Double precision version of AFUNC \\
\hline FERR & Function $F_{1}$ for evaluation of source depletion \\
\hline FERR I & Function $\mathrm{F}_{2}^{1}$ for evaluation of source depletion \\
\hline FRACT: & $\begin{array}{l}\text { Computes particulate deposition fraction in lung } \\
\text { compartments }\end{array}$ \\
\hline HEADER & Prints a new page heading \\
\hline HT & Computes effective stack height \\
\hline INHDF* & Calculates inhalation dose factors \\
\hline INTEG & $\begin{array}{l}\text { Performs numerical integration for source } \\
\text { depletion }\end{array}$ \\
\hline MESHGN:- & $\begin{array}{l}\text { Automatic meshing routine for a large quadri- } \\
\text { lateral area source. }\end{array}$ \\
\hline POLUT & $\begin{array}{l}\text { Computes normalized air concentrations at each } \\
\text { location of interest due to a point (or virtual } \\
\text { point) source }\end{array}$ \\
\hline POLUT 1* & $\begin{array}{l}\text { Computes normalized air concentrations (including } \\
\text { resuspension) for each wind speed class }\end{array}$ \\
\hline PTXOQ:- & $\begin{array}{l}\text { Computes normalized air concentrations for each } \\
\text { reference point in a polar grid }\end{array}$ \\
\hline QAREA * & Calculates the area of a quadrilateral area source \\
\hline$X L^{*}$ & $\begin{array}{l}\text { Computes distance from the source that corresponds } \\
\text { to a limiting value of the vertical dispersion } \\
\text { coefficient }\end{array}$ \\
\hline
\end{tabular}

Modules are listed alphabetically; see Fig. A.l for a schematic diagram of the relationships among the modules.

${ }^{b}$ An asterisk $(*)$ identifies a new module. 


\section{A.2.1 Function AFUNC}

Function AFUNC, along with DFUNC, is similar to a function of the same name from UDAD-IX (Momeni et al. 1979). AFUNC calculates the vertical-dispersion coefficient $\sigma_{z}(x)$, where $x$ represents downwind distance and is the lone argument of AFUNC. For elevated sources, this routine uses the same empirical formula as is used in the original version of MILDOS. For ground-level sources, the formula described in Sec. 2.2 of this manual is applied. The constants of the formula are stored in the common block ADATA. AFUNC is called by POLUT, POLUT1, and INTEG.

\section{A.2.2 Subroutine AREAS}

Subrouline AREAS incrementally computes air concentrations from a large-area source at receptor points designated by the program and by the user. AREAS is invoked by CHIQU, which passes along the IPACT value associgted with the source in question. Also passed are the mean annual morning and afternoon mixing heights. The common blocks ADATA, BDATA, PTDISP, and AREA are used by the AREAS subroutine. AREAS calls PTXOQ to compute normalized air concentrations at polar reference points. These concentrations are used to calculate weighted averages for the nodes of the finite elements.

\section{A.2.3 Function DE}

Function DE, called within subroutine INHDF, calculates the inhalation dose conversion factor for different isotopes, particle AMADs, and reference tissues. The common block DOSINH is used by DE.

Except for the effective dose equivalent, the inhalation dose factors for organs are calculated by the ICRP 30 nominal dose factors (at $1 \mu \mathrm{m}$ ) and the adjustment of A.MAD (see ICRP 1979, Part 1) by Eq. 20.

\section{A.2.4 Function DFUNC}

Function DFUNC is the double-precision version of AFUNC (described in Sec. A.2.1). The constants for the empirical formula used by DFUNC are stored in the common block DSTBZ. Common block ADATA is also used by DFUNC. DFUNC is called by FERR and FERR 1 .

\section{A.2.5 Subroutine FRACT}

Based on the ICRP deposition lung model (ICRP Task Group on Lung Dynamics 1966), the subroutine FRACT calculates the initial deposition fractions of inhaled aerosols in three lung regions (nasal-pharyngeal [N-P]), (trachea-bronchus [T-B]), and (pulmonary [P]). This subroutine is called by INHDF with input of A.MAD. No common blocks are used by FRACT. 


\section{A.2.6 Subroutine INHDF}

In BLOCK DATA, the function DCFA and its equivalent arrays in the original MILDOS are replaced by array IPSOL (in COMMON/BDATA/) and by variables in COMMON/DOSINH/. Common blocks ADATA and DDATA are also used. The new variables are used with the added routines to calculate the DCFA array based on the characteristics of inhaled particles. These characteristics are inhalation class and AMAD. The AMAD is equal to the product of the particle size and the square root of the density.

This subroutine calculates DCFA $\left[(\mathrm{mrem} / \mathrm{yr}) /\left(\mathrm{pCi} / \mathrm{m}^{3}\right)\right]$ from inhalation dose conversion factors (rem/ $/ \mathrm{Ci}$ ), which were input in BLOCK DATA in the original MILDOS code, for different AMADs, isotopes, and reference tissues. The calculation is bosed on the ICRP 30 (ICRP 1979) dose factors used with the ICRP deposition lung model. This routine performs the following two tasks:

- Evaluates deposition fractions -- The subroutine FRACT is called to calculate initial deposition fractions at different lung regions for inhaled aerosols.

- Calculates dose factor -- The functions DE and DFINT are used to calculate inhalation dose factors, DCFA (DCFA $=7.3 \times$ DE for dose equivalent of reference tissue).

\section{A.2.7 Subroutine MESHGN}

To facilitate the use of finite-element methotology for area sources, the input of each node and element is simplified to the description of a large quadrilateral area, i.e., vertex coordinates and divisions on two adjacent sides. This subroutine generates meshes automatically. These meshes later are used in subroutine AREAS. The detailed algorithm is presented in Sec. 2.1. Common blocks ADATA and DSTBZ are used by MESHGN.

\section{A.2.8 Subroutine POLUT1}

This routine computes the normalized air-concentration increment for a particular source, atmospheric-stability class, wind direction, windspeed, and receptor. POLUT1 is the finite-element version of POLUT; the modules are parallel in terms of functions performed. POLUT1 is called by PTXOQ to compute arrays XOQP $(5,45,6)$ and $\mathrm{XOQR}(7,45,6)$. Array $\mathrm{XOQP}(5,45,6)$ provides normalized air concentrations for up to 5 particle-size classes, 45 distances from the source, and 6 windspeed classes. Array $\mathrm{XOQR}(7,45,6)$ provides the same as above except for seven radionuclides ( $R \mathrm{n}-222$ and progeny) rather than particle-size clesses.

POLUT1 has three arguments: PSORC, DNWIND, and IRD. PSORC is the winderosion source term; DNWIND is one of the 45 selected downwind distances; and IRD is 
the index number of that downwind distance. POLUT1 uses the common blocks ADATA, INTG, and PTDISP and calls the subroutines AFUNC, DDEP, XL, and ACTDR.

\section{A.2.9 Subroutine PTXOG}

This subroutine calculates normalized air concentrations for points in a polar reference grid about the source. PTXOQ is invoked by AREAS to compute arrays PXOQ $(5,45,16)$ and $\operatorname{RXOQ}(7,45,16)$. Array PXOQ $(5,45,16)$ provides normalized air concentrations for up to 5 particle-size classes, 45 distances from the source, and 16 wind directions. Array $\mathrm{RXOQ}(7,45,16)$ provides the same, except for seven radionuclides (Rn-222 and progeny) rather than five particle-size classes.

The IPACT value associated with the source in question and the mean annual morning and afternoon mixing heights are the three arguments of PTXOQ. PTXOQ uses the common blocks ADATA, BDATA, AREA, and PTDISP and calls POLUT1 to access the straight-line, crosswind-integrated Gaussian dispersion model used in the former version of MILDOS.

\section{A.2.10 Function QAREA}

Function QAREA calculates the area of a quadrilaterally shaped region by simple trapezoidal rule. The function is called by subroutine CHIQU to automatically correct the emission rate of area sources. No common blocks are used.

\section{A.2.11 Subroutine XI}

This subroutine back-computes the downwind distance associated with a particular limiting value of $\sigma_{z}$. POLUT and POLUT1 both use XL in parallel code. XL has three arguments: $X$, the returned downwind distance; XL1, the $\sigma_{z}$ value of interest; and $H$, the effective plume height. If $H \geq H D P$, the $\sigma_{z}$ is taken as a Briggs coefficient. Otherwise, $\sigma_{z}$ is assumed to be a Martin-Tickvart coefficient. XL uses the common block ADATA.

\section{A.3 CHANGED MODULES}

To accommodate the new modules and new approaches taken by MILDOS-AREA, several MILDOS modules have undergone significant alterations in coding. In each case, the purpose of the module has not changed. (Table A.1 contains brief descriptions of module functions.) Any changes in functions perfo'med, calling routine, argument list, common-block usage, and subordinate modules are noted in this section. The affected modules are discussed in alphabetical order. 


\section{A.3.1 Subroutine CHIQU}

CHIQU now has three additional arguments, DMM (mean annual morning mixing height), DMA (mean annual afternoon mixing height), and KPAGE (current output report page number). CHIQU uses these to compute DM (mean annual mixing height) for point sources or small-area sources, according to the method discussed in Sec. 2.5. For largearea sources, CHIQU passes along DMM and DMA to subroutine AREAS, which in turn sends them to PTXOQ to perform the computation instead. Consequently, another common block, AREA, is used by CHIQU.

A whole new section of code in CHIQU is devoted to large-area sources. In it, the new NAMELIST NWAREA is read in and, if specified, nodes are automatically numbered and assigned coordinates by calling subroutine MESHGN. Subroutine AREAS is then called to perform finite-element integration for the area source.

\section{A.3.2 Subroutine DDEP}

DDEP evaluates the sum of integrals used in Eqs. 18a-c, Sec. 2.4. POLUT and POLUT1, after calling DDEP, use the sum to compute the plume-depletion factor. DDEP has the following new argument list:

- DNWIND -- Distance $(m)$ downwind to receptor,

- X1, X2 -- See Eq. 17, Sec. 2.4, and

- PHT -- Effective plume height $(\mathrm{m})$ at receptor location.

Numerous calls to INTEG are coded in DDEP, a subset of which is executed depending on the relative positions of $X 1, X 2$, and DNWIND.

\section{A.3.3 Function FERR}

FERR evaluates the integral in Eq. 19a, Sec. 2.4. FERR now calls DFUNC rather than directly computing the vertical-dispersion coefficient.

\section{A.3.4 Function FERR1}

This function evaluates the integral in Eq. 19b, Sec. 2.4, which is now more complex than in the original MLLDOS. FERR1 now also uses DFUNC.

\section{A.3.5 Subroutine HEADER}

HEADER now has two arguments, LUN (logical unit number) and IPAGE (the current page number). The arguments are needed because HEADER supplies page headers for two output files: a table of contents ( $L U N=3$, MILDOS.REP) and the regular 
MILDOS output (LUN $=2$, MILDOS.OUT). MILDOS.OUT is eventually appended to MILDOS.REP and then deleted by MILDOS.BAT, the DOS batch file that executes MILDOS-AREA. In the calling programs, IPAGE is replaced by KPAGE for LUN $=2$ and by LPAGE for LUN $=3$. The initial KPAGE is computed in MILMAIN.FOR from the number of lines and pages needed for the table of contents.

The input data file name is now included in the header lines, and the METSET field has been expanded from 16 to 24 characters.

\section{A.3.6 Subroutine INTEG}

Subroutine INTEG now calls AFUNC for computing an average verticaldispersion coefficient. INTEG now computes DH1 and DH2 instead of DX1 and stores them in DSTBZ for use by FERR1.

\section{A.3.7 Subroutine POLUT}

This subroutine incorporates the changes described in Sec. 2.3. For the concentration calculations, the minimum downwind distance is taken to be $10 \mathrm{~m}$ (as is tile case in POLUT1). POLUT calls AFUNC and XL in addition to DDEP and ACTDR. Common blocks ADATA and INTG are used by POLUT.

\section{A.3.8 Subroutines POPDOS, UNIDOS, and WRITER}

Each of these subroutines now has a single argument, KPAGE, the entry point page number to be used in calls to HEADER.

\section{A.4 COMMON BLOCKS}

All common blocks have been reordered to ensure proper boundary alignments; particularly, REAL*8 items (if any) have been moved to the beginning of common blocks, and INTEGER*2 items have been placed at the end. All integers, unless explicitly declared as INTEGER*4, are 16-bits in MILDOS-AREA.

All character data are now defined as character strings, and most such items have been placed in the new common block CHAR. CHAR appears in MILDOS (main), CHIQU, FRESH (block data), HEADER, POPDOS, UNIDOS, and WRITER.

In common block BDATA, arrays $R X Q(10,240,4)$ and $R X Q R N(10,240,7)$ are now defined as $\mathrm{RXQ}(4,240,10)$ and $\mathrm{RXQRN}(7,240,10)$. This corrects a design inefficiency in the original code.

Two new common blocks used to transfer data between the new modules are AREA and PTDISP. AREA contains parameters characterizing a large-area source and appears in the modules MILDOS (main), FRESH (block data), CHIQU, PTXOQ, and 
AREAS. The common block AREA also contains an array of 17 angles $(0-2 \pi) \mathrm{AN}$, and an array of 45 distances $(0-160 \mathrm{~km}) \mathrm{RN}$, to construct a reference polar grid around the source. The values in these arrays are set in block data FRESH.

PTDISP contains the normalized air-concentration arrays XOQP, XOQR, PXOQ, and RXOQ. PTDISP is used in the modules PTXOQ, AREAS, and POLUT1.

One additional common block, JOSINH, contains data needed to calculate inhalation dose factors, DCFA.

\section{A.5 REFERENCES}

International Commission on Radiological Protection, 1979, Limits for Intakes of Radionuclides by Workers (adopted July 1978), ICRP Publication 30.

ICRP Task Group on Lung Dynamics, 1966, Deposition and Retention Models for Internal Dosimetry of Human Respiratory Tract, Health Physics, 12:173-207.

Momeni, M.H., Y.C. Yuan, and A.J. Zielen, 1979, The Uranium Dispersion and Dosimetry (UD.AD) Code, Report NUREG/CR-0553, ANL/ES-72, Argonne National Laboratory, Argonne, Ill., for U.S. Nuclear Regulatory Commission, Washington, D.C.

Strenge, D.L., and T.J. Bander, 1981, MILDOS - A Computer Program for Calculating Environmental Radiation Doses from Uranium Recovery Operations, Report NUREG/CR2011, PNL-3767, Pacific Northwest Laboratory, Richland, Wash., for the U.S. Nuclear Regulatory Commission, Washington, D.C. 
APPENDIX B:

VALIDATION OF MILDOS-AREA AND

COMPARISON WITH AIRDOS-EPA 


\section{APPENDIX B:}

\section{VALIDATION OF MILDOS-AREA AND COMPARISON WITH AIRDOS-EPA}

Airborne Rn-222 concentrations and working levels calculated with the MILDOSAREA program were compared both with measured concentration data and with results from the current version of the computer code AIRDOS-EPA (Moore 1979, as updated in 1988). The site selected for use in this validation study was the Monticello, Utah, uranium mill tailings impoundments area. A large body of radon flux and concentration measurements exist for this site against which models can be validated. The code AIRDOS-EPA was chosen for comparison with MILDOS-AREA becauso AlRDOS-EPA is widely used to calculate atmospheric dispersion of radionuclides from a variety of sources. The measured radon concentrations and site-specific modeling data used in this validation study were provided by UNC Geotech.

Results of the source and dispersion modeling in MILDOS-AREA are generally in good agreement with measured Rn-222 concentrations. Table B. 1 compares $R n-222$ concentrations measured at the Monticello site with the values calculated using MILDOSAREA. The model-calculated concentrations are within $50 \%$ or less of measured values in most cases. In cases where the measured values are several times those estimated by MILDOS-AREA, the radon detectors that made the actual measurements may have been situated near localized hot spots, which may be prevalent over large sources emitting high radon fluxes. These results indicate that the source and dispersion treatment used in MILDOS-AREA is accurate and capable of reproducing measured data.

The comparison between $\mathrm{Rn}-222$ concentrations and working level estimates calculated by the MILDOS-AREA and. AIRDOS-EPA codes is more straightforward (Table B.2). In AIRDOS-EPA, sources are always circular and situated at the origin. For the Monticello site, where a number of large, physically separated sources are involved, the scurce in AIRDOS-EPA is taken to be a circular area at the origin of the same total area and source strength as the separate sources modeled in MILDOS-AREA. Radon-222 concentrations calculated by the two codes are in very good agreement for distances greater than about $\mathrm{i} \mathrm{km}$ from the origin. However, for distances very close to the origin, the AIRDOS-EPA results are much higher (as much as $50 \%$ higher for some locations) than MILDOS-AREA results. This difference is due to the source-description limitations inherent in the AIRDOS-EPA code.

Of more interest is the comparison of estimated working levels, which are used to estimate health effects in many cases. Near the source, AIRDOS-EPA estimates larger working levels than does MILDOS-AREA, even though the Rn-222 concentrations estimated by AIRDOS-EPA are smaller. At large distances, where the Rn-222 concentrations calculated by the two codes are equal, MILDOS-AREA estimates larger working levels. 
TABLE B.1 Comparison between Measured Rn-222 Concentrations and MILDOS-AREA Calculated Concentrations and Working Levels for Monticello, Utah

\begin{tabular}{|c|c|c|c|}
\hline \multirow[b]{2}{*}{ Location ${ }^{2}$} & \multirow{2}{*}{$\begin{array}{c}\text { Annual Average } \\
\text { Measured Rn-222 } \\
(\mathrm{pCi} / \mathrm{L})\end{array}$} & \multicolumn{2}{|c|}{$\begin{array}{l}\text { MILDOS-AREA } \\
\text { Calculation }\end{array}$} \\
\hline & & $(\mathrm{pCi} / \mathrm{L})^{\mathrm{b}}$ & WL \\
\hline Acid pile & $3.40 \pm 0.37$ & 2.41 & $1.77 \mathrm{E}-4$ \\
\hline East pile & $4.83 \pm 0.47$ & 2.53 & $2.87 \mathrm{E}-4$ \\
\hline Vanadium pile & $4.53 \pm 0.45$ & 4.01 & $3.93 E-4$ \\
\hline Carbonate pile & $6.44 \pm 0.55$ & 5.54 & $3.21 \mathrm{E}-4$ \\
\hline ST-1 & $1.73 \pm 0.24$ & 0.57 & $6.23 \mathrm{E}-5$ \\
\hline ST -2 & $2.34 \pm 0.29$ & 1.88 & $1.22 \mathrm{E}-4$ \\
\hline ST -3 & $1.11 \pm 0.11$ & 0.67 & $9.09 E-5$ \\
\hline ST -4 & $1.18 \pm 0.11$ & 0.50 & $4.57 \mathrm{E}-5$ \\
\hline ST -5 & $1.24 \pm 0.15$ & 1.36 & $2.78 E-4$ \\
\hline ST -6 & $1.98 \pm 0.17$ & 1.94 & $3.32 \mathrm{E}-4$ \\
\hline ST-7 & $2.28 \pm 0.27$ & 2.48 & $2.83 E-4$ \\
\hline ST-8 & $2.57 \pm 0.23$ & 0.80 & $1.07 \mathrm{E}-4$ \\
\hline ST-9 & $0.49 \pm 0.05$ & 0.63 & $9.82 \mathrm{E}-5$ \\
\hline ST-10 & $0.26 \pm 0.03$ & 0.43 & $2.59 E-5$ \\
\hline ST-11 & $0.48 \pm 0.06$ & 0.44 & $2.72 E-5$ \\
\hline $\mathrm{ST}-12$ & $0.34 \pm 0.04$ & 0.46 & $4.59 E-5$ \\
\hline$S T-13$ & $0.41 \pm 0.05$ & 0.45 & $4.33 E-5$ \\
\hline ST-14 & $0.46 \pm 0.06$ & 0.44 & $3.53 \mathrm{E}-5$ \\
\hline ST-15 & $0.46 \pm 0.05$ & 0.45 & $4.55 E-5$ \\
\hline
\end{tabular}

aThe locations designated by the code "ST" represent sites at which measurements were made.

bIncludes background of $0.41 \mathrm{pCi} / \mathrm{L}$.

The differences in working level values can be understood by considering the methods used by the two codes to calculate working levels from concentrations. To determine the radon daughter equilibrium fraction at grid locations, AIRDOS-EPA linearly interpolates between preset values in a spatial mesh. The limiting values are $27 \%$ for $200 \mathrm{~m}$ and less and $70 \%$ for $20,000 \mathrm{~m}$ and greater. MILDOS-AREA employs a direct calculation of working levels based on actual radon daughter concentrations. The results above indicate that equilibrium fractions are less than $27 \%$ at small distances, and greater than: 70\% (approaching 100\%) at very large distances from the source. Thus, in AIRDOS-EPA the estimated health effects for maximally exposed individuals, who are generally close to the source, will be too high in many cases. Conversely, the magnitude of health effects for persons at larger distances will be underestimated. 
TABLE B.2 Comparison of AIRDOS-EPA and MILDOS-AREA Radon

Concentrations and Working Levels for Monticello, Utah, Site

\begin{tabular}{|c|c|c|c|c|c|}
\hline \multirow{2}{*}{$\begin{array}{l}\text { Wind } \\
\text { Blowing } \\
\text { Toward }\end{array}$} & \multirow{2}{*}{$\begin{array}{c}\text { Distance } \\
\text { Erom } \\
\text { Center } \\
\text { of Source } \\
(\mathrm{m})\end{array}$} & \multicolumn{2}{|c|}{$\begin{array}{c}\text { Air Concentrations } \\
(\mathrm{pCi} / \mathrm{L})\end{array}$} & \multicolumn{2}{|c|}{ Working Levels } \\
\hline & & AIRDOS-EPA & MILDOS-AREA & AIRDOS-EPA & MILDOS-AREA \\
\hline ENE & 200 & 1.8 & 1.87 & $4.9 E-3$ & $3.17 \mathrm{E}-4$ \\
\hline ENE & 600 & $2.9 \mathrm{E}-1$ & $3.36 \mathrm{E}-1$ & $8.4 E-4$ & $2.17 E-4$ \\
\hline ENE & 1,200 & $1.4 \mathrm{E}-1$ & $1.21 E-1$ & 4. $3 E-4$ & $1.45 E-4$ \\
\hline ENE & 2,000 & $5.7 E-2$ & $5.81 E-2$ & $2.0 E-4$ & $1.04 \mathrm{E}-4$ \\
\hline ENE & 3,200 & $2.6 \mathrm{E}-2$ & $2.89 \mathrm{E}-2$ & $1.0 \mathrm{E}-4$ & $7.33 E-5$ \\
\hline ENE & 5,600 & 1. $3 \mathrm{E}-2$ & $1.43 \mathrm{E}-2$ & $6.0 E-5$ & $5.08 E-5$ \\
\hline ENE & 7,000 & $8.1 E-3$ & $8.52 E-3$ & $4.0 E-5$ & $3.81 E-5$ \\
\hline ENE & 9,000 & $5.5 E-3$ & $5.78 \mathrm{E}-3$ & $3.0 E-5$ & $3.05 E-5$ \\
\hline ENE & 15,000 & $2.5 E-3$ & $2.64 \mathrm{E}-3$ & $1.6 E-5$ & $1.86 \mathrm{E}-5$ \\
\hline ENE & 30,000 & $8.7 E-4$ & $8.96 E-4$ & $6.1 E-6$ & $8.14 E-6$ \\
\hline ENE & 50,000 & $4.0 E-4$ & $4.04 E-4$ & $2.8 E-6$ & $3.93 E-6$ \\
\hline ENE & 70,000 & $2 \cdot 3 E-4$ & $2.38 \mathrm{E}-4$ & 1. $6 E-6$ & $2.34 E-6$ \\
\hline $\mathrm{NE}$ & 200 & 1.8 & 1.19 & $5.0 E-3$ & $3.14 E-4$ \\
\hline $\mathrm{NE}$ & 600 & $2.1 E-1$ & $1.89 \mathrm{E}-1$ & $6.1 \mathrm{E}-4$ & 1. $28 E-4$ \\
\hline NE & 1,200 & $3.2 \mathrm{E}-2$ & $4.85 \mathrm{E}-2$ & $1.0 \mathrm{E}-4$ & $6.02 E-5$ \\
\hline NE & 2,000 & $1.4 \mathrm{E}-2$ & $1.95 \mathrm{E}-2$ & $1.7 \mathrm{E}-5$ & $3.62 E-5$ \\
\hline $\mathrm{NE}$ & 3,200 & $6.2 E-3$ & $8.60 \mathrm{E}-3$ & $2.4 \mathrm{E}-5$ & $2.29 \mathrm{E}-5$ \\
\hline NE & 5,000 & $3.2 E-3$ & $3.95 E-3$ & $1.4 \mathrm{E}-5$ & $1.47 E-5$ \\
\hline $\mathrm{NE}$ & 7,000 & $1.9 E-3$ & $2.26 \mathrm{E}-3$ & $9.5 \mathrm{E}-6$ & $1.06 \mathrm{E}-5$ \\
\hline $\mathrm{NE}$ & 9,000 & $1.3 E-3$ & $1.50 E-3$ & $7.1 \mathrm{E}-6$ & $8.18 E-6$ \\
\hline $\mathrm{NE}$ & 15,000 & $6.0 E-4$ & $6.62 \mathrm{E}-4$ & $3.9 E-6$ & $4.74 E-6$ \\
\hline $\mathrm{NE}$ & 30,000 & $2.1 E-4$ & $2.20 E-4$ & $1.4 \mathrm{E}-6$ & $1.98 E-6$ \\
\hline $\mathrm{NE}$ & 50,000 & $9.4 \mathrm{E}-5$ & $9.77 \mathrm{E}-5$ & $6.5 E-7$ & $9.46 E-7$ \\
\hline $\mathrm{NE}$ & 70,000 & $5.5 E-5$ & $5.72 E-5$ & $3.9 E-7$ & $5.63 \mathrm{E}-7$ \\
\hline NNE & 200 & 1.8 & $8.81 \mathrm{E}-1$ & $5.0 \mathrm{E}-3$ & $2.54 E-4$ \\
\hline NNE & 600 & $1.4 \mathrm{E}-1$ & $1.37 \mathrm{E}-1$ & 4. $2 E-4$ & $8.28 E-5$ \\
\hline NNE & 1,200 & $4.2 E-2$ & $4.43 E-2$ & $1.4 \mathrm{E}-4$ & $4.63 E-5$ \\
\hline NNE & 2,000 & $1.8 \mathrm{E}-2$ & $2.01 E-2$ & $6.3 E-5$ & $3.07 E-5$ \\
\hline NNE & 3,200 & $8 \cdot 3 E-3$ & $9.64 \mathrm{E}-3$ & 3. $2 E-5$ & $2.08 E-5$ \\
\hline NNE & 5,000 & $4.2 E-3$ & $4.66 \mathrm{E}-3$ & $1.9 E-5$ & $1.40 E-5$ \\
\hline NNE & 7,000 & $2.5 E-3$ & $2.75 E-3$ & 1. $3 E-5$ & $1.05 E-5$ \\
\hline NNE & 9,000 & $1.7 E-3$ & $1.85 E-3$ & $9.4 E-6$ & $8.36 E-6$ \\
\hline NNE & 15,000 & $7.9 E-4$ & $8.37 E-4$ & $5.2 E-6$ & $5.16 E-6$ \\
\hline NNE & 30,000 & $2.7 E-4$ & $2.84 E-4$ & $1.9 E-6$ & $2.38 E-6$ \\
\hline NNE & 50,000 & $1.3 E-4$ & $1.28 E-4$ & $8.7 E-7$ & $1.20 \mathrm{E}-6$ \\
\hline NNE & 70,000 & $7.4 E-5$ & $7.54 E-2$ & $5.2 E-7$ & 7. $34 \mathrm{E}-7$ \\
\hline
\end{tabular}


TABLE B.2 (Cont'd)

\begin{tabular}{|c|c|c|c|c|c|}
\hline \multirow{2}{*}{$\begin{array}{l}\text { Wind } \\
\text { Blowing } \\
\text { Toward }\end{array}$} & \multirow{2}{*}{$\begin{array}{l}\text { Distance } \\
\text { from } \\
\text { Center } \\
\text { of Source } \\
\text { (m) }\end{array}$} & \multicolumn{2}{|c|}{$\begin{array}{c}\text { Air Concentrations } \\
(\mathrm{pCi} / \mathrm{L})\end{array}$} & \multicolumn{2}{|c|}{ Working Levels } \\
\hline & & AIRDOS-EPA & MILDOS-AREA & AIRDOS-EPA & MILDOS-AREA \\
\hline $\mathbf{N}$ & 200 & 1.7 & $8.42 \mathrm{E}-1$ & $4.7 E-3$ & $2.21 \mathrm{E}-4$ \\
\hline N & 600 & $1.5 \mathrm{E}-1$ & $1.52 E-2$ & $4.5 E-4$ & $8.47 E-5$ \\
\hline $\mathrm{N}$ & 1,200 & $4.8 \mathrm{E}-2$ & $4.98 \mathrm{E}-2$ & $1.5 E-4$ & $4.88 \mathrm{E}-5$ \\
\hline N & 2,000 & $2.0 E-2$ & $2.26 \mathrm{E}-2$ & $7.1 \mathrm{E}-5$ & $3.26 \mathrm{E}-5$ \\
\hline $\mathrm{N}$ & 3,200 & $9.4 E-3$ & $1.09 \mathrm{E}-2$ & $3.7 E-5$ & $2.22 E-5$ \\
\hline $\mathrm{N}$ & 5,000 & $4.8 E-3$ & $5.30 E-3$ & $2.1 E-5$ & $1.49 E-5$ \\
\hline $\mathrm{N}$ & 7,000 & $2.9 E-3$ & $3.12 E-3$ & $1.4 E-5$ & $1.11 E-5$ \\
\hline $\mathrm{N}$ & 9,000 & $2.0 E-3$ & $2.11 E-3$ & 1. $1 E-5$ & $8.85 E-6$ \\
\hline $\mathrm{N}$ & 15,000 & $9.1 E-4$ & $9.55 E-4$ & $5.9 E-6$ & $5.49 \mathrm{E}-6$ \\
\hline $\mathrm{N}$ & 30,000 & 3. $1 E-4$ & $3.24 E-4$ & $2.2 E-6$ & $2.60 \mathrm{E}-6$ \\
\hline $\mathrm{N}$ & 50,000 & $1.4 E-4$ & $1.46 E-4$ & $1.0 E-6$ & 1. $35 E-6$ \\
\hline $\mathrm{N}$ & 70,000 & $8.5 E-5$ & $8.63 E-5$ & $5.9 E-7$ & $8.32 \mathrm{E}-7$ \\
\hline
\end{tabular}

In summary, the dispersion treatment in MILDOS-AREA computes radionuclide concentration vaiues that generally are in good agreement with measured values and that are in very good agreement with concentrations calculated using AIRDOS-EPA for distances beyond the point where the limitations in AIRDOS-EPA source geometry are unimportant. Differences in the way that the two codes treat radon daughter equilibrium fractions cause differences in estimated working levels and in individual and population health effects based on working levels.

\section{REFERENCE}

Moore, R.E., et al., 1979, AIRDOJ-EPA: A Computerized Methodology for Estimating Environmental Concentrations and Dose to Man from Airborne Releases of Radionuclides, U.S. Environmental Protection Agency, Report EPA 520/1-79-009 (reprint of Oak Ridge National Laboratory Report ORNL-5532), Office of Radiation Programs, Washington, D.C., Dec. 
APPENDIX C:

SAMPLE PROBLEMS AND OUTPUT 


\section{APPENDIX C:}

\section{SAMPLE PROBLEMS AND OUTPUT}

\section{C.1 INTRODUCTION}

Three sample problems are presented in this appendix to illustrate the use of the program MILDOS-AREA. New features of the urogram are emphasized. The first sample problem includes two hypothetical area sources: one emitting at a constant rate of release and the other wind-eroded and thus emitting at a variable rate of release. Situated around these sources are four receptor locations. The hypothetical situation is depicted diagrammatically in Fig. C.l. The data input file (SAMPLE.DAT) needed to execute MILDOS-AREA and selected sample results of the calculation of radiological impacts to the four hypothetical receptors are presented in Secs. C.2 and C.3, respectively.

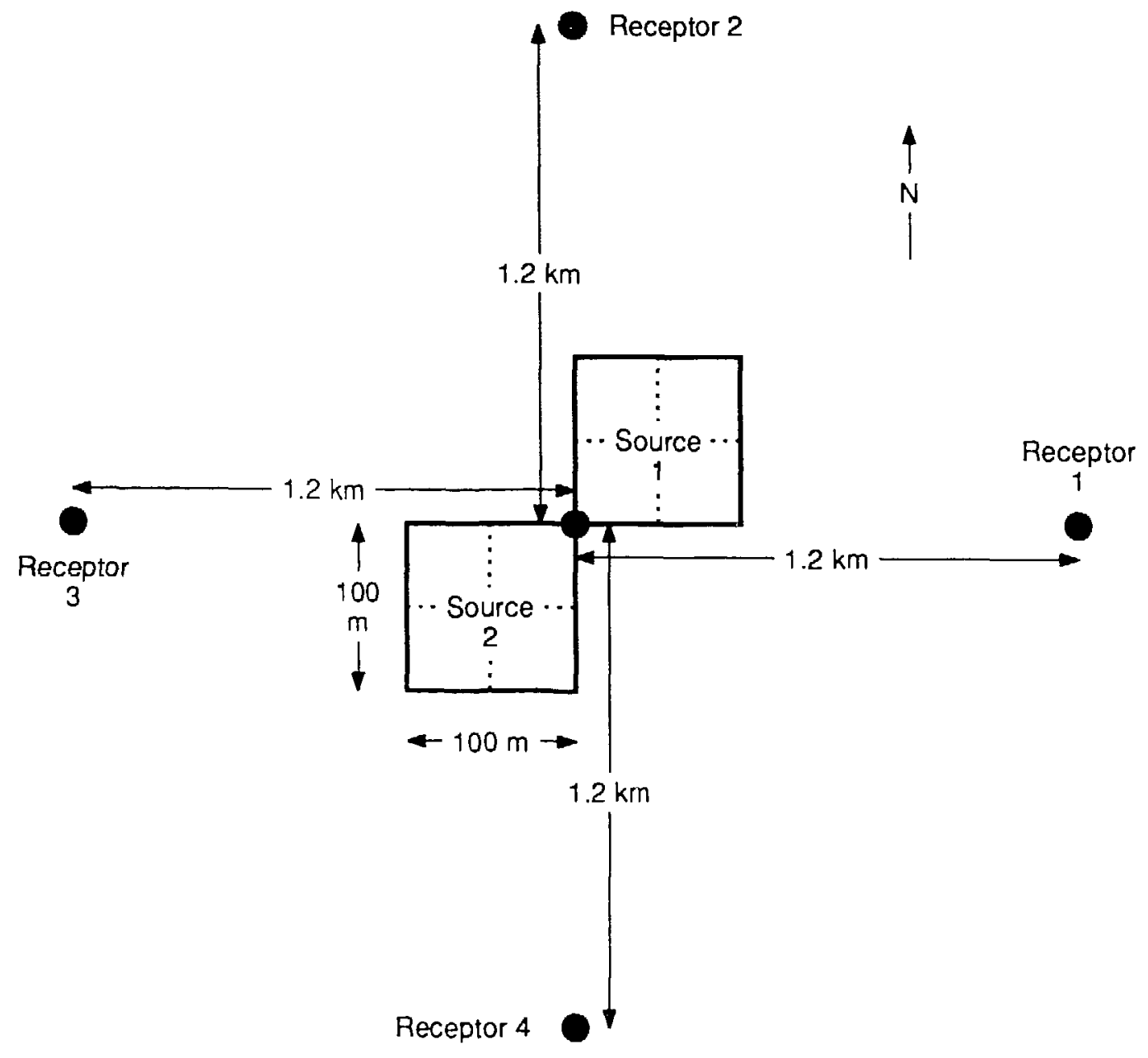

FIGURE C.1 Schematic Diagram of Hypothetical Situation for SAMPLE.DAT Problem 
The second sample problem resembles the first sample problem in the MILDOS user's guide (Strenge and Bander 1981), with only slight modification. This problem also demonstrates automatic node numbering. The detailed input information is explained in the original user's guide. Section C.4 shows the input listing (TESTC1.DAT) for the second sample problem. For easy cross-reference, the parameters are arranged in the same order as described in the tables of Sec. 4. For further clarity, the sources and receptors are described in Tables C.1 and C.2, respectively.

The two fence boundary receptor locations have been moved slightly from their positions in the problem presented in the original MILDOS user's guide. The fence boundary in the eastern sector has been moved $440 \mathrm{~m}$ west to make it closer to the third tailings pile. The fence boundary in the south-southeastern sector has been shifted $160 \mathrm{~m}$ to the south to ensure that is off tailings pile \#3. Each tailings area is assumed to be square and is divided into four finite elements, as designated in the NWAREA namelists of Sec. C.3. Since $\mathrm{NEX}=0$, automatic node numbering is in effect for all three piles. Section C.5 contains selected output from execution of this problem.

The third sample problem resembles the second problem with the exception that the last area source is irregularly shaped and requires manual node numbering. Figure C.2 is an xy-grid layout of the Sierra Madre Mill region, showing the source and receptor locations for the second and third problems. In this diagram, the third tailings pile is represented two ways -- as square (sample problem two) and as irregularly shaped (sample problem three). The crescent-like shape is divided into five quadrilaterals, and the nodes are numbered according to the bottom-to-top, left-to-right rule. (The elements are numbered in like manner for consistency, but may be numbered in any fashion.) Table C.2 shows the meanings of the receptor abbreviations on the diagram. Section C.6 contains the listing of the input (TESTC2.DAT) for this third sample problem. The input for this problem is almost the same as in Sec. C.4, except the area for tailings pile \#3 is slightly larger $\left(0.840 \mathrm{~km}^{2}\right.$ instead of $\left.0.827 \mathrm{~km}^{2}\right)$, and the corresponding NWAREA namelist has been redefined. Now,

$$
\begin{aligned}
& \mathrm{NEX}=0 \text {, } \\
& \mathrm{NAS}=5 \text {, } \\
& \text { NNODE }=13 \\
& \text { NODE }=1,2,3,4,3,4,5,6,5,6,9,10,7,8,11,12,8,10,12,13 \text {, } \\
& \mathrm{XS}=1200 ., 1600 ., 1200 ., 1600 ., 1200 ., 1600 ., 200 ., 800 ., 1200 ., 1600 ., \\
& 600 ., 800 ., 1000 \text {, } \\
& Y S=-2200 .,-1800 ., 2^{*}-1600 ., 2^{*}-1200 ., 4^{*}-800 ., 3^{*}-400 .
\end{aligned}
$$

for the third tailings pile. The selected output report for this example of manual node numbering is given in Sec. C.7. 
Source

\begin{tabular}{|c|c|c|c|c|c|c|c|}
\hline \multirow[b]{2}{*}{ Parameter } & \multirow{2}{*}{$\begin{array}{c}\text { Yellowcake } \\
\text { Stack }\end{array}$} & \multirow[b]{2}{*}{ Ore Pad } & \multirow{2}{*}{$\begin{array}{c}\text { Grizzly } \\
\text { Dump-Hopper }\end{array}$} & \multicolumn{3}{|c|}{ Tailings Piles } & \multirow{2}{*}{$\begin{array}{c}\text { Variable } \\
\text { Name }\end{array}$} \\
\hline & & & & 1 & 2 & 3 & \\
\hline \multicolumn{8}{|l|}{ Location } \\
\hline East-west $(\mathrm{km})$ & 0 & $0.4 \mathrm{E}$ & $0.2 \mathrm{E}$ & $1.39 \mathrm{E}$ & $1.30 \mathrm{~W}$ & $1.09 E$ & $\operatorname{SORCE}(1, i)$ \\
\hline North-south $(\mathrm{km})$ & 0 & $0.4 \mathrm{~N}$ & $0.2 \mathrm{~N}$ & $0.98 \mathrm{~N}$ & $0.84 \mathrm{~S}$ & $0.98 \mathrm{~s}$ & $\operatorname{SORCE}(2, i)$ \\
\hline Elevation (m) & 20.0 & 6.0 & 0 & -10.0 & -10.0 & -10.0 & $\operatorname{SORCE}(3, i)$ \\
\hline Area $\left(\mathrm{km}^{2}\right)$ & 0 & 0.16 & 0 & 0.143 & 0.270 & 0.827 & $\operatorname{SORCE}(4, i)$ \\
\hline Particle Size Set & 1 & 3 & 2 & 3 & 3 & 3 & $\operatorname{SORCE}(11, i)$ \\
\hline $\begin{array}{l}\text { Release Rates ( } \mathrm{Ci} / \mathrm{yr} \text { ) } \\
\text { U-238 } \\
\text { Th-230 } \\
\mathrm{Ra}-226 \\
\mathrm{~Pb}-210 \\
\mathrm{Rn}-222\end{array}$ & $\begin{array}{c}4.14 \times 10^{-2} \\
2.16 \times 10^{-3} \\
8.62 \times 10^{-5} \\
8.62 \times 10^{-5} \\
0\end{array}$ & $\begin{array}{l}4.08 \times 10^{-2} \\
4.08 \times 10^{-2} \\
4.08 \times 10^{-2} \\
4.08 \times 10^{-2} \\
1.09 \times 10^{3}\end{array}$ & $\begin{array}{l}2.60 \times 10^{-2} \\
2.60 \times 10^{-2} \\
2.60 \times 10^{-2} \\
2.60 \times 10^{-2} \\
4.16 \times 10^{1}\end{array}$ & $\begin{array}{l}5.67 \times 10^{-3} \\
1.35 \times 10^{-1} \\
1.41 \times 10^{-1} \\
1.41 \times 10^{-1} \\
1.28 \times 10^{3}\end{array}$ & $\begin{array}{l}1.61 \times 10^{-2} \\
3.82 \times 10^{-1} \\
4.01 \times 10^{-1} \\
4.01 \times 10^{-1} \\
3.64 \times 10^{3}\end{array}$ & $\begin{array}{c}6.56 \times 10^{-2} \\
1.56 \\
1.64 \\
1.64 \\
1.49 \times 10^{4}\end{array}$ & $\begin{array}{l}\operatorname{SORCE}(5, i) \\
\operatorname{SORCE}(6, i) \\
\operatorname{SORCE}(7, i) \\
\operatorname{SORCE}(8, i) \\
\operatorname{SORCE}(9, i)\end{array}$ \\
\hline \multicolumn{8}{|l|}{ Stack Data } \\
\hline Velocity $(\mathrm{m} / \mathrm{s})$ & 17.0 & 0 & 0 & 0 & 0 & 0 & $\operatorname{SORCE}(12, i)$ \\
\hline Diameter (m) & 1.0 & 0 & 0 & 0 & 0 & 0 & $\operatorname{SORCE}(12, \mathrm{i})$ \\
\hline $\begin{array}{l}\text { Tailings Activity } \\
\text { Mix Set }\end{array}$ & & & & & & & \\
\hline Mix Set & 0 & 0 & 0 & 1 & 2 & 3 & IPACT(i) \\
\hline
\end{tabular}

Source: Modified from Strenge and Bander 1981. 
TABLE C.2 Receptor Locations for Sample Problems 2 and 3

\begin{tabular}{|c|c|c|c|}
\hline \multirow[b]{2}{*}{ Receptor ${ }^{a}$} & Locations & Relative to Mill & \multirow{2}{*}{$\frac{1 \text { Center }}{\text { Elevation }}$} \\
\hline & $\begin{array}{c}\text { East-West } \\
(\mathrm{km})\end{array}$ & $\begin{array}{c}\text { North-South } \\
(\mathrm{km})\end{array}$ & \\
\hline Eence boundary $E(F B E)^{e}$ & 1.600 & -0.200 & 8.8 \\
\hline Fence boundary SSE (FB SSE) & 1.080 & -1.600 & 2.4 \\
\hline Grazing $E(G E)$ & 2.560 & 0.0 & 3.7 \\
\hline Grazing ESE ( $G$ ESE) & 2.584 & -0.890 & -1.4 \\
\hline Nearest resident NNW (NR NNW) & -0.448 & 1.466 & $12 \cdot 3$ \\
\hline $\begin{array}{l}\text { Nearest resident in the } \\
\text { prevailing wind direction } \\
\text { (NR PWD) }\end{array}$ & 2.168 & 2.168 & 10.2 \\
\hline
\end{tabular}

${ }^{a}$ See Fig. C.2 for receptor locations.

${ }^{b} A$ positive number indicates east and a negative number west.

$c_{A}$ positive number indicates north and negative number south.

${ }^{d} A$ positive number indicates elevation above that of the mill center, and a negative number indicates elevation below that of the mill center.

${ }^{e}$ Coding in parentheses corresponds to receptor locations shown in Eig. C.2.

Source: Modified from Strenge and Bander 1981. 


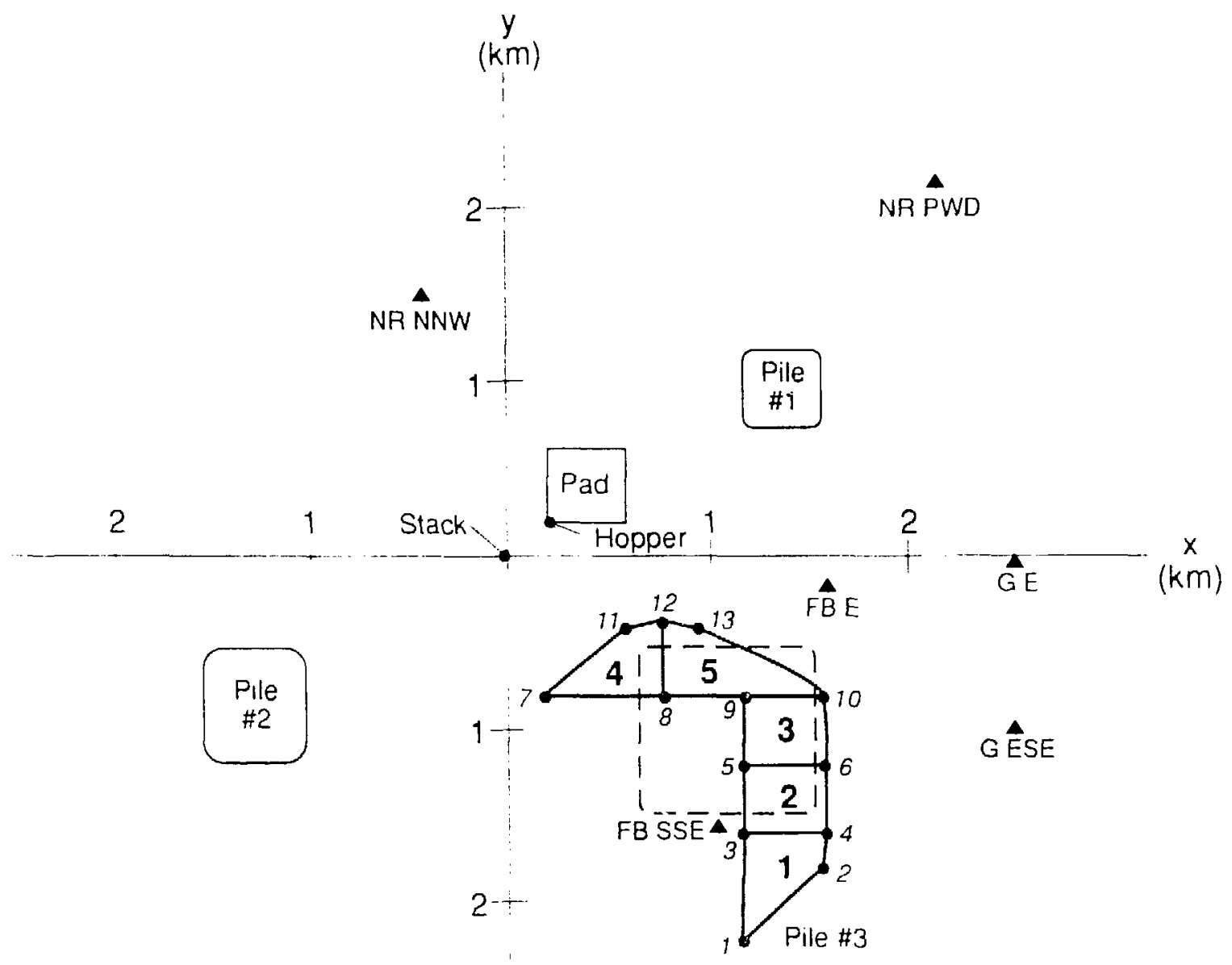

- Receptor Loca: on

FIGURE C.2 Spatial Orientation of Sources and Receptors for TESTC1.DAT (dashed pile 3) and TESTC2.DAT (solid pile 3) Problems (see Table C.2 for meanings of receptor abbreviations) 


\section{C.2 LISTING OF TEST PROBLEM SAMPLE.DAT}

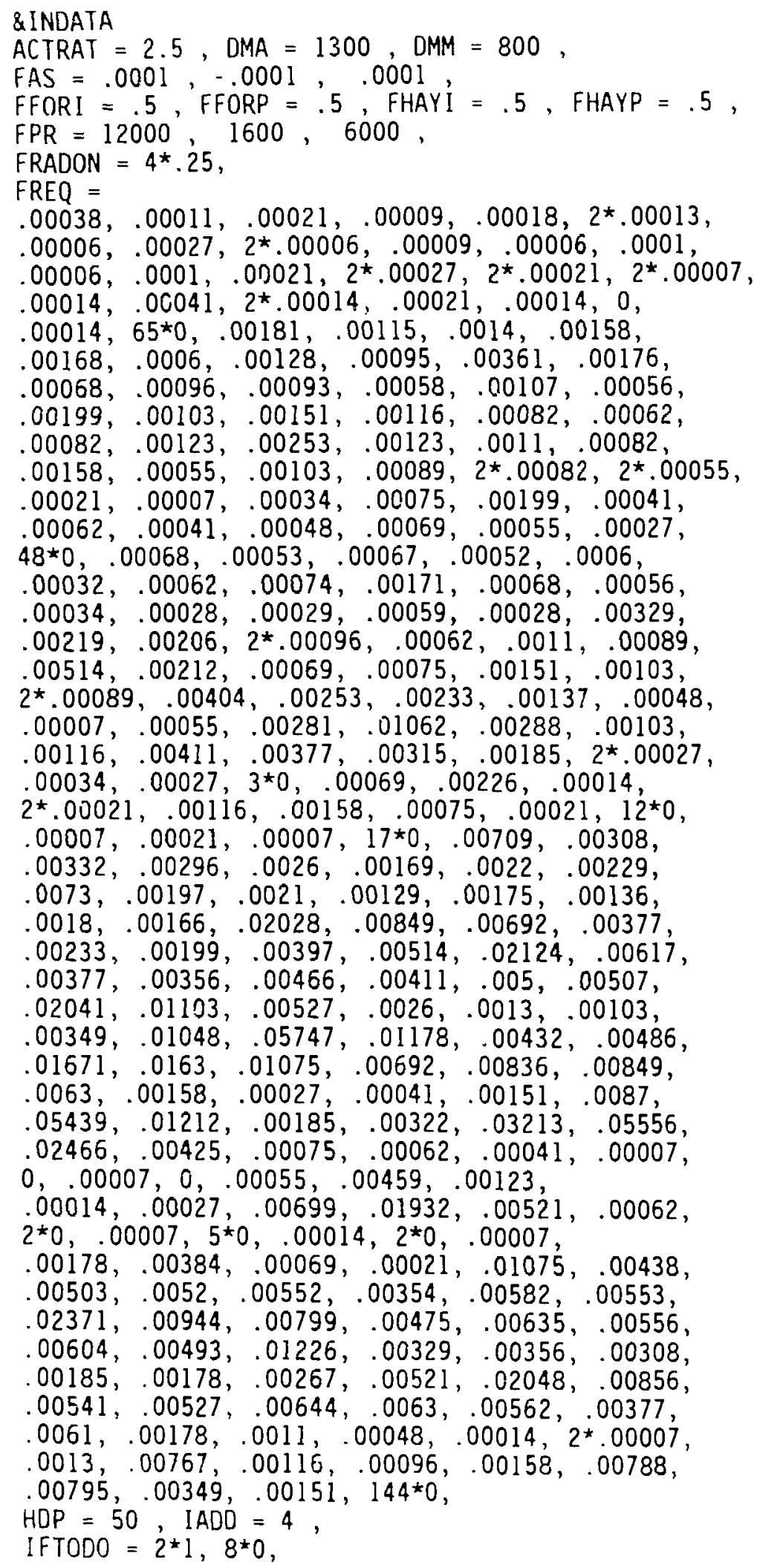


IPACT $=1,2,8 * 0$,

IPOP =

$572,286,401,515,221,3178$,

$6078,4842,7011,7959,9705,9708$,

$1145,286,1603,1288,221,4073$,

$6789,9505,12220,14591,15101,15552$,

$1145,1288,1402,258,779,4073$,

$6789,9505,12220,13210,12551,14482$,

$1145,1431,1202,1545,221,883$,

$1472,3921,8870,14092,15611,16542$,

$572,1431,2003,258,221,883$,

$1472,2060,2649,3238,5900,8403$,

$572,1431,2003,773,221,883$,

$1472,2060,2649,3238,3826,4415$, $572,143,21,26,221,883$,

$1472,2060,2707,3677,4761,6404$,

$916,215,21,26,221,883$,

$1472,2060,3296,4995,5904,6812$,

$286,143,200,26,221,883$,

$1472,2060,2721,4995,5904,6812$,

$12,15,21,26,221,883$,

$2068,3870,3656,4995,5904,6812$,

$12,15,21,26,221,1360$,

$3460,4844,6143,6304,6368,6812$,

$12,15,21,26,370,2076$,

$3460,4844,4789,4665,4838,5162$,

$114,15,21,26,519,2076$,

$3460,4844,2809,3214,3798,4382$,

$114,15,21,26,519,2009$,

$2904,3677,4427,4092,3798,4382$,

$229,15,21,44,519,1476$,

$2348,3287,4226,5166,5841,6384$,

$286,15,21,26,260,1409$,

$2348,3287,4226,6121,7718,7256$,

IPSOL $=3 * 3,4 * 2$,

IRTYPE $=7 \star 10,41^{\star}-1$,

$J C=2^{\star} 0,2^{\star} 1,0,4 * 1,0$,

NSORCE $=2$, NSTEP $=2$.

PACT $=12 \star 100$,

PAJUST $=10^{\star} 1$,

PTSZ $=1.5,3,7.7,54, .3$,

PTSZFC $=0,1,2 \star 0.1,5 * 0, .3, .7$,

QAJUST $\approx 200 * 1$,

SORCE $=$

$3^{\star} 0, .000557,4^{\star} .01,1,5001,1$,

$4 * 0, .000557,4^{\star} .01,1,5002,3$,

$97 * 0$,

SRNS $=3 * 1$,

TSTART $=1985$, TSTEP $=3,100,8 * 0$,

XRECEP $=$

$1.2,3 * 0,1.2,0,-1.2,3 * 0,-1.2,133^{*} 0$, \&END

SAMPLE SITE

METEOROLOGIC STATION

OISPOSAL PILE

WIND-ERODED AREA

E RESIDENT

N RESIDENT 


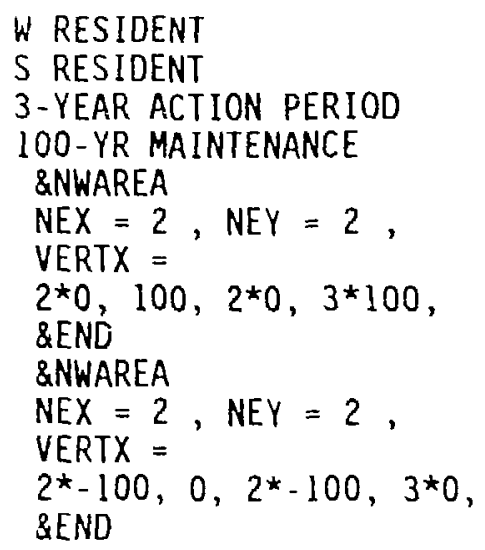




\section{C.3 SELECTED OUTPUT FROM TEST PROBLEM SAMPLE.DAT}

REGION: SAMPLE SITE

METSET: METEOROLOGIC STATION
COOE : MILDOS-AREA $(03 / 89)$

DATA: SAMPLE.DAT
PAGE 1

$04 / 01 / 89$

TABLE OF CONTENTS

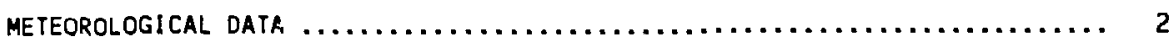

INDIVIDUAL RECEPTORS \& MISCELLANEOUS INPUT DATA $\ldots \ldots \ldots \ldots \ldots \ldots \ldots \ldots \ldots \ldots . \ldots$

POPULATION DISTRIBUTION $\ldots \ldots \ldots \ldots \ldots \ldots \ldots \ldots \ldots \ldots \ldots \ldots \ldots \ldots \ldots \ldots \ldots$

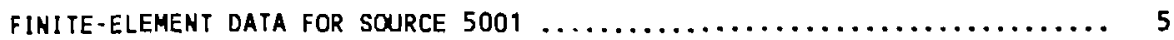

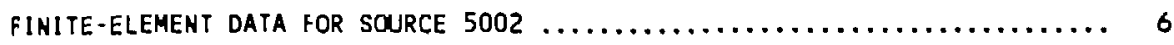

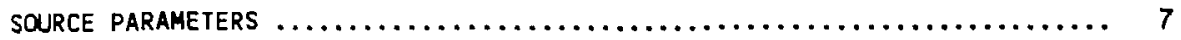

DOSE CONVERSION FACTORS $\ldots \ldots \ldots \ldots \ldots \ldots \ldots \ldots \ldots \ldots \ldots \ldots \ldots \ldots \ldots \ldots \ldots \ldots \ldots \ldots$

TIME STEP 1, 3-YEAR ACTION PERIOD

CONCENTRATION DATA FOR SPATIAL INTERVALS $\ldots \ldots \ldots \ldots \ldots \ldots \ldots \ldots \ldots \ldots \ldots \ldots$

ANNUAL POPULATION DOSE COMMITHENTS, PERSOH-REM PER YEAR

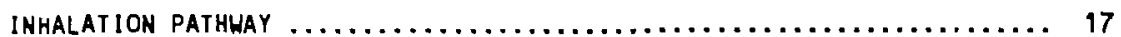

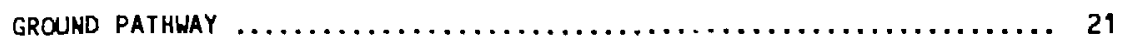

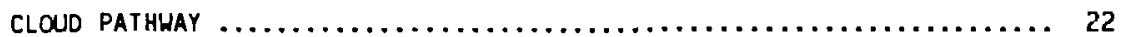

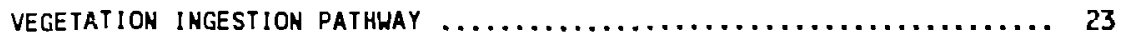

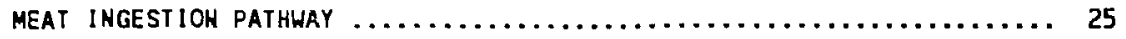

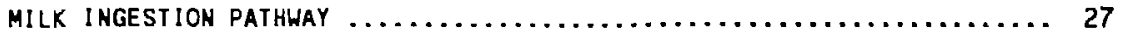

POPULATION DOSE SUMMARY .............................. 29

INDIVIDUAL RECEPTOR PARTICULATE CONCENTRATIONS $\ldots \ldots \ldots \ldots \ldots \ldots \ldots \ldots \ldots . \ldots$

! IDIVIDUAL RECEPTOR RADON AND RADON DAUGHTER CONCENTRATIONS ......... 31

INDIVIDUAL RECEPIOR MPC CHECK AND/OR AHAUAL DOSE COMMITMENTS $\ldots \ldots \ldots \ldots . .32$

TIME STEP 2, 100-YR MAINTENANCE

CONCENTRATION DATA FOR SPATIAL INTERVALS $\ldots \ldots \ldots \ldots \ldots \ldots \ldots \ldots \ldots \ldots \ldots .40$

ANNUAL POPULATION DOSE COMMITMENTS, PERSOH-REM PER YEAR

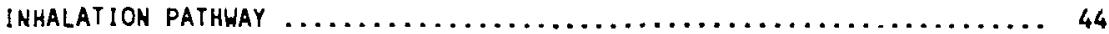

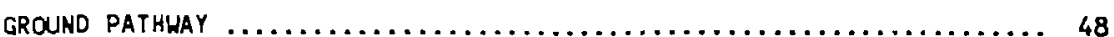

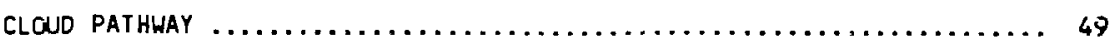

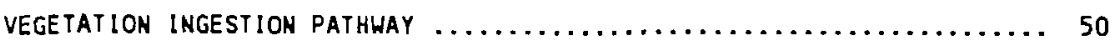

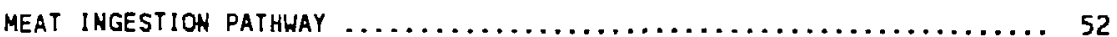

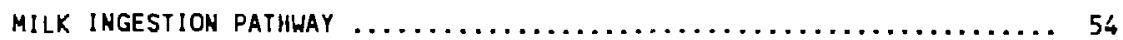

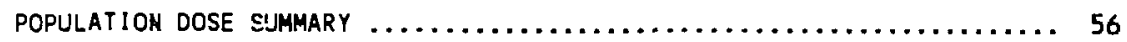

INDIVIDUAL RECEPTOR PARTICULATE CONCENTRATIONS $\ldots \ldots \ldots \ldots \ldots \ldots \ldots \ldots \ldots \ldots .57$

INDIVIDUAL RECEPTOR RADON AND RADON DAUGHTER CONCENTRATIONS $\ldots \ldots \ldots \ldots \ldots .58$

INDIVIDUAL RECEPTOR MPC CHECK AND/OR ANMUAL DOSE COMMITMENTS ........ 59 
REGION: SAMPLE SITE

METSET: METEOROLOGIC STATIOM

COOE: MILDDS-AREA (03/89)

PAGE 2

DATA: SAHPLE.DAT 04/01/89

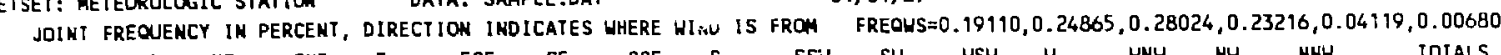

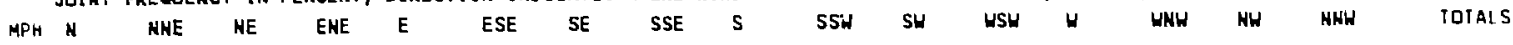

SIABLLITY CLASS 1

$\begin{array}{lllllllllllllllllllll}1.5 & 0.0380 & 0.0110 & 0.0210 & 0.0090 & 0.0180 & 0.0130 & 0.0130 & 0.0060 & 0.0270 & 0.0060 & 0.0060 & 0.0090 & 0.0060 & 0.0100 & 0.0060 & 0.0100\end{array}$

$\begin{array}{llllllllllllllllllllllllll}5.5 & 0.0210 & 0.0270 & 0.0270 & 0.0210 & 0.0210 & 0.0070 & 0.0070 & 0.0140 & 0.0410 & 0.0140 & 0.0140 & 0.0210 & 0.0140 & 0.0000 & 0.0140 & 0.0000\end{array}$

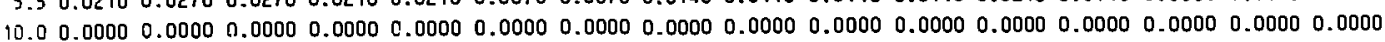

$\begin{array}{llllllllllllllllllllll}15.5 & 0.0000 & 0.0000 & 0.0000 & 0.0000 & 0.0000 & 0.0000 & 0.0000 & 0.0000 & 0.0000 & 0.0000 & 0.0000 & 0.0000 & 0.0000 & 0.0000 & 0.0000 & 0.0000\end{array}$

$\begin{array}{lllllllllllllllllllll}21.5 & 0.0000 & 0.0000 & 0.0000 & 0.0000 & 0.0000 & 0.0000 & 0.0000 & 0.0000 & 0.0000 & 0.0000 & 0.0000 & 0.0000 & 0.0000 & 0.0000 & 0.0000 & 0.0000\end{array}$

$\begin{array}{lllllllllllllllllllllllllllllllll}28.0 & 0.0000 & 0.0000 & 0.0000 & 0.0000 & 0.0000 & 0.0000 & 0.0000 & 0.0000 & 0.0000 & 0.0000 & 0.0000 & 0.0000 & 0.0000 & 0.0000 & 0.0000 & 0.0000\end{array}$

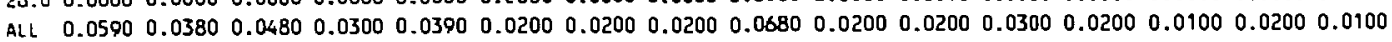

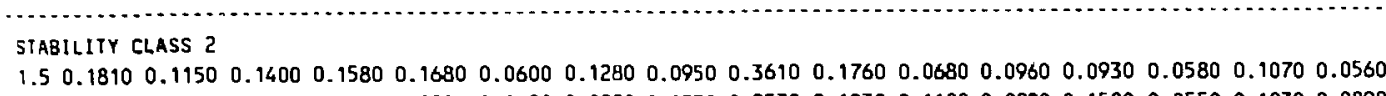

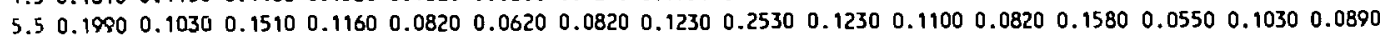

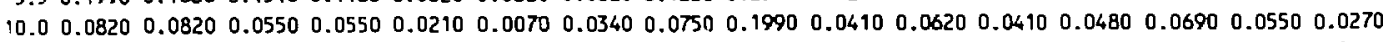
$\begin{array}{llllllllllllllllllll}15.5 & 0.0000 & 0.0000 & 0.0000 & 0.0000 & 0.0000 & 0.0000 & 0.0000 & 0.0000 & 0.0000 & 0.0000 & 0.0000 & 0.0000 & 0.0000 & 0.0000 & 0.0000 & 0.0000\end{array}$ $\begin{array}{llllllllllllllllllllllll}21.5 & 0.0000 & 0.0000 & 0.0000 & 0.0000 & 0.0000 & 0.0000 & 0.0000 & 0.0000 & 0.0000 & 0.0000 & 0.0000 & 0.0000 & 0.0000 & 0.0000 & 0.0000 & 0.0000\end{array}$

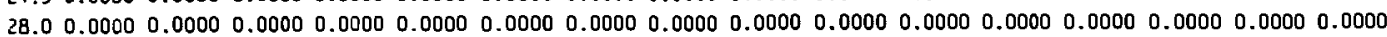

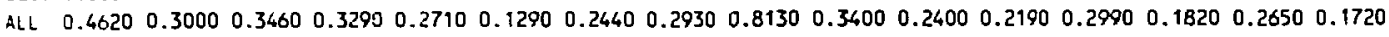

$\begin{array}{lllllllllllllllllll}\text { SIABILIT CLASS } 3 & \\ 1.5 & 0.0690 & 0.0530 & 0.0670 & 0.0520 & 0.0600 & 0.0320 & 0.0620 & 0.0740 & 0.1710 & 0.0680 & 0.0560 & 0.0340 & 0.0280 & 0.0290 & 0.0590 & 0.0280\end{array}$ $\begin{array}{llllllllllllllllllllll}1.5 & 0.0690 & 0.0530 & 0.0670 & 0.0520 & 0.0600 & 0.0320 & 0.0620 & 0.0740 & 0.1710 & 0.0680 & 0.0560 & 0.0340 & 0.0280 & 0.0290 & 0.0590 & 0.0280 \\ 5.5 & 0.3290 & 0.2190 & 0.2060 & 0.0960 & 0.0960 & 0.0620 & 0.1100 & 0.0890 & 0.5140 & 0.2120 & 0.0690 & 0.0750 & 0.1510 & 0.1030 & 0.0890 & 0.0890\end{array}$ $\begin{array}{cccccccccccccccccccccccc}10.0 & 0.4040 & 0.2530 & 0.2330 & 0.1370 & 0.0480 & 0.0070 & 0.0550 & 0.2810 & 1.0620 & 0.2880 & 0.1030 & 0.1160 & 0.4110 & 0.3770 & 0.3150 & 0.1850\end{array}$ $\begin{array}{lllllllllllllllllllllllllllll}15.5 & 0.0270 & 0.0270 & 0.0340 & 0.0270 & 0.0000 & 0.0000 & 0.0000 & 0.0690 & 0.2260 & 0.0140 & 0.0210 & 0.0210 & 0.1160 & 0.1580 & 0.0750 & 0.0210\end{array}$

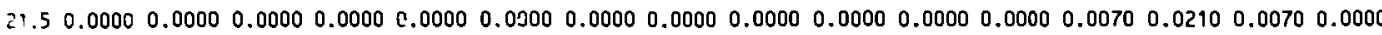
$\begin{array}{llllllllllllllllllllllllll}2 & 0.0000 & 0.0000 & 0.0000 & 0.0000 & 0.0000 & 0.0000 & 0.0000 & 0.0000 & 0.0000 & 0.0000 & 0.0000 & 0.0000 & 0.0000 & 0.0000 & 0.0000 & 0.0000\end{array}$

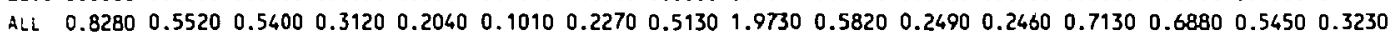
STABILITY CLASS 4

$\begin{array}{lllllllllllllllllllllllll}1.5 & 0.7090 & 0.3080 & 0.3320 & 0.2960 & 0.2600 & 0.1690 & 0.2200 & 0.2290 & 0.7300 & 0.1970 & 0.2100 & 0.1290 & 0.1750 & 0.1360 & 0.1800 & 0.1660\end{array}$ $\begin{array}{lllllllllllllllllllllll}5.5 & 2.0280 & 0.8490 & 0.6920 & 0.3770 & 0.2330 & 0.1990 & 0.3970 & 0.5140 & 2.1240 & 0.6170 & 0.3770 & 0.3560 & 0.4660 & 0.4110 & 0.5000 & 0.5070\end{array}$ $\begin{array}{llllllllllllllllllllllll}10.0 & 2.0410 & 1.1030 & 0.5270 & 0.2600 & 0.1300 & 0.1030 & 0.3490 & 1.0480 & 5.7470 & 1.1780 & 0.4320 & 0.4860 & 1.6710 & 1.6300 & 1.0750 & 0.6920\end{array}$ $\begin{array}{lllllllllllllllllllllll}15.5 & 0.8360 & 0.8490 & 0.6300 & 0.1580 & 0.0270 & 0.0410 & 0.1510 & 0.8700 & 5.4390 & 1.2120 & 0.1850 & 0.3220 & 3.2130 & 5.5560 & 2.4660 & 0.4250\end{array}$ $\begin{array}{llllllllllllllllllllllllll}21.5 & 0.0750 & 0.0620 & 0.0410 & 0.0070 & 0.0000 & 0.0070 & 0.0600 & 0.0550 & 0.4590 & 0.1230 & 0.0140 & 0.0270 & 0.6990 & 1.9320 & 0.5210 & 0.0620\end{array}$

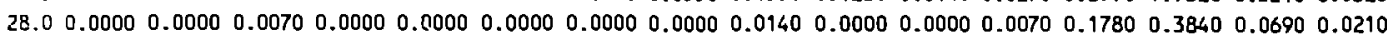
ALL $\quad 5.68903 .17102 .22901 .09800 .6500 \quad 0.51901 .1170 \quad 2.716014 .51303 .3270 \quad 1.2180 \quad 1.32706 .402010 .04904 .8110 \quad 1.8730$

\section{SIABILITY CLASS 5}

$\begin{array}{llllllllllllllllllll}1.5 & 1.0750 & 0.4380 & 0.5030 & 0.5200 & 0.5520 & 0.3540 & 0.5820 & 0.5530 & 2.3710 & 0.4440 & 0.7990 & 0.4750 & 0.6350 & 0.5560 & 0.6040 & 0.4930\end{array}$ $\begin{array}{lllllllllllllllllllllllll}5.5 & 1.2260 & 0.3290 & 0.3560 & 0.3080 & 0.1850 & 0.1780 & 0.2670 & 0.5210 & 2.0480 & 0.8560 & 0.5410 & 0.5270 & 0.6440 & 0.6300 & 0.5620 & 0.3770\end{array}$

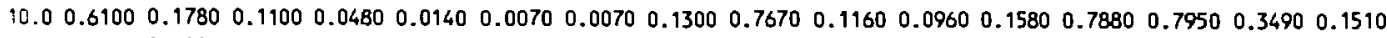
$\begin{array}{lllllllllllllllllllllllll}15.5 & 0.0000 & 0.0090 & 0.0000 & 0.0000 & 0.0000 & 0.0000 & 0.0000 & 0.0000 & 0.0000 & 0.0000 & 0.0000 & 0.0000 & 0.0000 & 0.0000 & 0.0000 & 0.0000\end{array}$

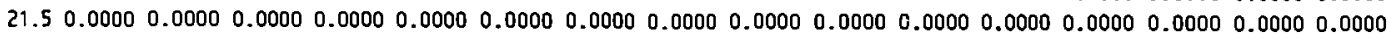
$\begin{array}{llllllllllllllllllllllllll}28.0 & 0.0000 & 0.0000 & 0.0000 & 0.0000 & 0.0000 & 0.0000 & 0.0000 & 0.0000 & 0.0000 & 0.0000 & 0.0000 & 0.0000 & 0.0000 & 0.0000 & 0.0000 & 0.0000\end{array}$ ALL $2.9110 \quad 0.9450 \quad 0.9690 \quad 0.8760 \quad 0.7510 \quad 0.5390 \quad 0.8560 \quad 1.2040 \quad 5.1860 \quad 1.9160 \quad 1.4360 \quad 1.1600 \quad 2.0670 \quad 1.9810 \quad 1.5150 \quad 1.0210$

\section{SIABILITY CLASS 6}

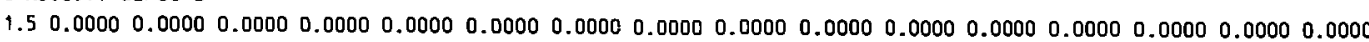

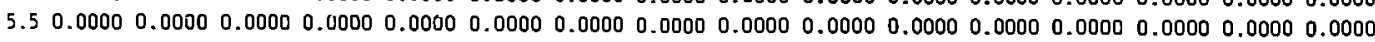

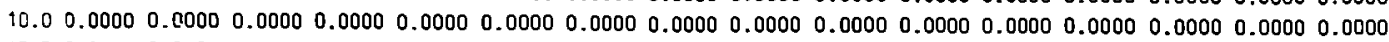
$\begin{array}{lllllllllllllllllllllllll}15.5 & 0.0000 & 0.0000 & 0.0000 & 0.0000 & 0.0000 & 0.0000 & 0.0000 & 0.0000 & 0.0000 & 0.0000 & 0.0000 & 0.0000 & 0.0000 & 0.0000 & 0.0000 & 0.0000\end{array}$

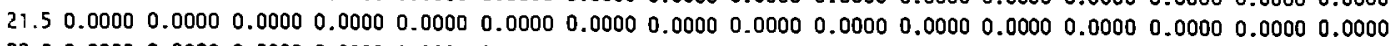

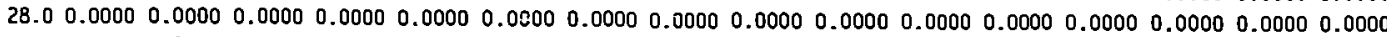

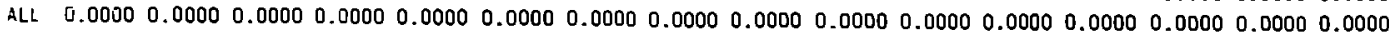


REGIOH: SAMPLE SITE

COOE : MILDOS-AREA (03/89)

DATA: SAMPLE.DAT

PAGE 3

$04 / 01 / 89$

METSET: METEOROLOAIC STATION

INDIVIOUAL RECEPIOR LOCATION DATA,

\begin{tabular}{|c|c|c|c|c|c|c|c|c|c|c|c|c|c|}
\hline 1 & LOCATION MAKES & $X(K M)$ & $Y(K \mathbf{M})$ & $2(H)$ & DIST (KM) & TYPE & 1 & LOCATION HAMES & $X(K M)$ & $Y(K M)$ & $2(M)$ & IST (KM) & TYPE \\
\hline 1 & E RESIDENT & 1.20 & 0.00 & 0.00 & 1.20 & 10 & 3 & RESIDENT & -1.20 & 0.00 & 0.00 & 1.20 & 10 \\
\hline
\end{tabular}

miscellaheous inPutable parameter Values

\begin{tabular}{|c|c|c|c|c|c|c|c|c|c|c|}
\hline DNA & Din & TSTART & FEORI & FHAYI & FFORP & FHAYP & FPR(1) & FPR (2) & FPR(3) & ACTRAT \\
\hline 800.0 & 1300.0 & 1985.00 & 0.50 & 0.50 & 0.50 & 0.50 & 12000.00 & 1600.00 & 6000.00 & 2.50 \\
\hline
\end{tabular}

IPACI EQUALS 1, 2,

JC Equals $0,0,1,1,0,1,1,1,1,0$

TIME STEP DATA.... STEP NAMES

1 3-YEAR ACTIOH PERIOO

2 100-YR haINTEhahCE

$\begin{array}{cc}\text { LENGTH, YRS } & \text { IFTOOO } \\ 3.00 & 1 \\ 100.00 & 1\end{array}$

XRHO EQUALS 1.5, 2.5, 3.5, 4.5, 7.5, 15.0, 25.0, 35.0, 45.0, 55.0, 65.0, 75.0,

MDP EQUALS 50.0 
REJION: SAMPLE SITE

METSET: METEOROLOGIC STATIOH
CDOE: MILUOS-AREA (03/89)

DATA: SAHPLE.DAT
PAGE 4

$04 / 01 / 89$

POPULATION DISTRIBUTIOH

\begin{tabular}{|c|c|c|c|c|c|c|c|c|c|c|c|c|c|c|c|c|}
\hline KILOME IERS & $\begin{array}{ll}1 & k \\
1 & 0.0\end{array}$ & $\begin{array}{r}\text { HNE } \\
22.5\end{array}$ & $\begin{array}{c}\text { NE } \\
45.0\end{array}$ & $\begin{array}{r}\text { ENE } \\
67.5\end{array}$ & $\begin{array}{l}E \\
90.0\end{array}$ & $\begin{array}{r}\text { ESE } \\
112.5\end{array}$ & $\begin{array}{c}\text { SE } \\
135.0\end{array}$ & $\begin{array}{r}\text { SSE } \\
157.5\end{array}$ & $\begin{array}{c}\text { S } \\
180.0\end{array}$ & $\begin{array}{r}\text { SEW } \\
202.5\end{array}$ & $\begin{array}{c}\text { SH } \\
225.0\end{array}$ & $\begin{array}{r}\text { HSW } \\
247.5\end{array}$ & $\begin{array}{c}H \\
270.0\end{array}$ & $\begin{array}{r}\text { HNH } \\
292.5\end{array}$ & $\begin{array}{c}\mathrm{NH} \\
315.0\end{array}$ & $\begin{array}{r}\text { HNH } \\
337.5\end{array}$ \\
\hline $1.0-2.0$ & 1 & 1145 & 1145 & 1145 & $5 \pi 2$ & $5 \pi$ & 572 & 916 & 286 & 12 & 12 & 12 & 114 & 114 & 229 & 286 \\
\hline $2.0-3.0$ & 286 & 286 & 1288 & 1431 & 1431 & 1431 & 143 & 215 & 143 & 15 & 15 & 15 & 15 & 15 & 15 & 15 \\
\hline $3.0-4.0$ & 401 & 1603 & 1402 & 1202 & 2003 & 2003 & 21 & 21 & 200 & 21 & 21 & 21 & 21 & 21 & 21 & 21 \\
\hline $4.0-5.0$ & 515 & 1288 & 258 & 1545 & 258 & 773 & 26 & 26 & 26 & 26 & 26 & 26 & 26 & 26 & 44 & 26 \\
\hline $5.0 \cdot 10.0$ & 221 & 221 & 779 & 221 & 221 & 221 & 221 & 221 & 221 & 221 & 221 & 370 & 519 & 519 & 519 & 260 \\
\hline $10.0-20.0$ & 3178 & 4073 & 4073 & 883 & 883 & 883 & 883 & 883 & 893 & 883 & 1360 & 2076 & 2076 & 2009 & 1476 & 1409 \\
\hline $20.0-30.0$ & 6078 & 6789 & 6789 & 1472 & 1472 & 1472 & 1672 & 1472 & 1472 & 2068 & 3460 & 3460 & 3460 & 2904 & 2348 & 2348 \\
\hline $30.0-40.0$ & 4842 & 9505 & 9505 & 3921 & 2060 & 2060 & 2060 & 2060 & 2060 & 3870 & 4844 & 4844 & 4844 & 3677 & 3287 & 3287 \\
\hline $40.0-50.0$ & $70 \div 1$ & 12220 & 12220 & 8870 & $26-9$ & 2649 & 2707 & 3296 & 2721 & 3656 & 6143 & 4789 & 2809 & 4427 & 4226 & 4226 \\
\hline $50.0-60.0$ & 7959 & 14591 & 13210 & 14092 & 3238 & 3238 & 3677 & 4995 & 4995 & 4995 & 6304 & 4665 & 3214 & 4092 & 5166 & 6121 \\
\hline $60.0-70.0$ & 9705 & 15101 & 12551 & 15611 & 5900 & 3826 & 4761 & 5904 & 5904 & 5904 & 6368 & 4838 & 3798 & 3798 & 5841 & 7718 \\
\hline $70.0-80.0$ & 9708 & 15552 & 14482 & 16542 & 8403 & 4415 & 6404 & 6812 & 6812 & 6812 & 6812 & 5162 & 4382 & 4382 & 6384 & 7256 \\
\hline $1.0-80.0$ & 50476 & 82374 & 77702 & 66935 & 29090 & 23543 & 22947 & 26821 & 25723 & 28483 & 35586 & 30278 & 25278 & 25984 & 29556 & 32973 \\
\hline
\end{tabular}


REGION: SAMPLE SITE

METSET: METEOROLOGIC STATIOH
COOE : MILDOS-AREA $(03 / 89)$

GATA: SAMPLE.DAT
PAGE 5

$04 / 01 / 80$

FINITE ELEMENT DATA FOR SOURCE nO. 1: JPX $=1$ ID 5001

VERTEX (H) $=0.0000 E+00 \quad 0.0000 E+00 \quad 1.0000 E+02 \quad 0.0000 E+00 \quad 0.0000 E+00 \quad 1.0000 E+02 \quad 1.0000 E+02 \quad 1.0000 E+02$

AREA SOURCE ELEMENT HO. $=1$

AREA SOURCE ELEMENT HO. $=2$

AREA SOURCE ELEMENT HO. $=3$

AREA SOURCE ELEMENT HO. $=4$

$\begin{array}{lllll}\text { MOOES }= & 1 & 4 & 2 & 5 \\ \text { MOOES }= & 2 & 5 & 3 & 6 \\ \text { MOOES }= & 4 & 7 & 5 & 8 \\ \text { HDOES }= & 5 & 8 & 6 & 9\end{array}$

NDOAL COORDIHATES ( $M$ ):

$\begin{array}{llll}\text { HODE NO. }= & 1 & X S=0.0000 E+00 & Y S=0.0000 E+00 \\ \text { HODE NO. }= & 2 & X S=0.0000 E+00 & Y S=5.0000 E+01 \\ \text { HODE HO. }= & 3 & X S=0.0000 E+00 & Y S=1.0000 E+02 \\ \text { NODE NO. }= & 4 & X S=5.0000 E+01 & Y S=0.0000 E+00 \\ \text { HOOE HO. }= & 5 & X S=5.0000 E+01 & Y S=5.0000 E+01 \\ \text { NODE NO. }= & 6 & X S=5.0000 E+01 & Y S=1.0000 E+02 \\ \text { NOOE NO. }=7 & X S=1.0000 E+02 & Y S=0.0000 E+00 \\ \text { HODE NO. }= & 8 & X S=1.0000 E+02 & Y S=5.0000 E+01 \\ \text { HOOE NO. }=9 & X S=1.0000 E+02 & Y S=1.0000 E+02\end{array}$


REGION: SAMPLE SITE

HETSET: METEOROLOGIC STATION
COOE: MILDOS-AREA (03/89)

DATA: SAMPLE.DAT
PAGE ?

$04 / 01 / 89$

NUHBER OF SOURCES $=2$

\begin{tabular}{|c|c|c|c|c|c|c|c|c|c|c|c|c|c|}
\hline & AH & $\mathbf{K M}$ & $\mathbf{M}$ & KH2 & & & CI/YEAR & & & & PSIZE & $M /$ SEC & \\
\hline No. & $x$ & $Y$ & $z$ & AREA & $U-238$ & Th. 230 & $\mathrm{Ra}=226$ & Pb- 210 & $R n-222$ & 10 & SE T & EXIT VEL & SOURCE HAHE \\
\hline 1 & 0.00 & 0.00 & 0.00 & 0.0100 & $7.89 E-03$ & $7.89 E-03$ & $7.89 E-03$ & $7.895 \cdot 03$ & $3.16 E-01$ & 5001 & 1 & $0.00 E+00$ & DISPOSAL PILE \\
\hline 2 & 0.00 & 0.00 & 0.00 & 0.0100 & $9.65 E-02$ & $9.65 E-02$ & $9.65 E-02$ & $9.65 E-02$ & $3.16 E-01$ & 5002 & 3 & $0.00 E+00$ & HIND-EROOED AREA \\
\hline
\end{tabular}

INPUT TALLS ACTIVITIES, PCI/G

SET URANIUM THORILM RADIUM LEAD

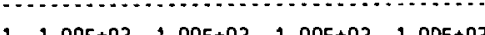

$2 \quad 1.00 E+02 \quad 1.00 E+02 \quad 1.00 E+02 \quad 1.00 E+02$

$3 \quad 1.00 E+02 \quad 1.00 E+02 \quad 1.00 E+02 \quad 1.00 E+02$
NHA AHD FRACTIOHAL DISTRIBUTION

$\begin{array}{lllll}\text { SET } & 1.5 & 3.0 & 7.7 & 54.0 \\ 1 & 0.000 & 1.000 & 0.000 & 0.000 \\ 2 & 1.000 & 0.000 & 0.000 & 0.000 \\ 3 & 0.000 & 0.000 & 0.300 & 0.700\end{array}$

\begin{tabular}{|c|c|c|c|c|c|c|c|c|c|c|}
\hline & & PART ICULATE & SOURCE STREK & AGTH MULTIPLIE & ERS BY TIME & STEP, 2 TIME & STEP(S) & USED FOR THIS & RUN & \\
\hline SOURCE & ISTEP 1 & TSIEP 2 & ISIEP 3 & TSTEP 4 & ISIEP 5 & ISIEP 6 & ISTEP 7 & TSTEP 8 & ISIEP 9 & ISTEP 10 \\
\hline MUMMER & $3.00 Y R S$ & $100.00 Y R 5$ & $0.00 Y R S$ & 0.00 YRS & D.0OYRS & 0.0OYRS & 0.00 YRs & 0.00 YRS & 0. OOYRS & $0.00 Y R S$ \\
\hline$\cdots$ & & - & $\cdots$ & , & & & & & $\cdots$ & \\
\hline \multirow[t]{2}{*}{2} & $1.000 E-00$ & $1.000 E+00$ & $1.000 \mathrm{E}+00$ & $1.000 E+00$ & $1.000 \mathrm{E}+00$ & $1.000 E+00$ & $1.000 E+00$ & $1.000 E+00$ & 1. $.000 E+00$ & $1.000 E+00$ \\
\hline & RADON SOU & RCE STRENGTH & MULTIPLIERS & BY TIME STEP, & , 2 IIME STE & EP (5) USED FOR & THIS RUN & & & \\
\hline NUMBER & 3. OOYRS & 10G.DOYRS & 0. DOYRS & 0.00 YRS & 0.00 YRS & $0.00 Y R S$ & 0. GOYRS & 0.00 YRS & 0.00 YRS & 0.00 YRS \\
\hline & & & 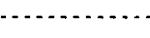 & $\ldots \ldots$ & $\cdots$ & $\ldots$ & 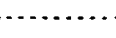 & & $\cdots$ & $\cdots$ \\
\hline 1 & $1.050 \mathrm{E}+00$ & $1.000 E+00$ & $1.000 E+00$ & $1.000 E+00$ & $1.000 E+00$ & $1.000 E+00$ & $1.000 E+00$ & $1.000 E+00$ & $1.000 E+00$ & $1.00 C E+00$ \\
\hline 2 & $1.000 E+00$ & $1.000 E+00$ & $1.000 E+00$ & $1.000 E+00$ & $1.000 E+00$ & $1.000 E+00$ & $1.000 E+00$ & $1.000 E+00$ & $1.000 E+00$ & 1. $.000 E+00$ \\
\hline
\end{tabular}


INHALATION DOSE CONVERSION FACTORS, MREM/YR PER PCI/M3, FOR AGE GROUP OF IMFANT

\begin{tabular}{|c|c|c|c|c|c|c|c|}
\hline$A H A D=1.5 \mathrm{~lm}$ & $u-238$ & $U-236$ & Th. 230 & $\mathrm{Ra}-226$ & $\mathrm{~Pb}-210$ & $B i-210$ & Po-210 \\
\hline EFFECTIV & $3.42 E+03$ & $3.85 E+03$ & $4.68 E+03$ & $6.49 E+02$ & $1.74 E+02$ & $4.10 E+00$ & 8. $80 E+02$ \\
\hline BONE & $4.84 E+01$ & $5.61 E+01$ & $2.17 \mathrm{E}+04$ & $5.92 E+02$ & $5.47 E+02$ & $7.03 E-02$ & $2.10 E+02$ \\
\hline AVG.LUHG & $2.69 E+04$ & $3.08 E+06$ & $3.10 E+04$ & $4.17 E+03$ & $5.07 E+01$ & $5.96 E+01$ & $3.36 E+03$ \\
\hline LIVER & $3.51 \mathrm{E}-\mathrm{U} 1$ & $3.23 E-01$ & $1.16 \mathrm{E}+02$ & $4.42 E+01$ & $2.83 E+03$ & $1.32 E+00$ & $2.54 E+02$ \\
\hline KIDNEY & $4.67 E+01$ & $5.23 E+01$ & $1.21 E+01$ & $1.68 E+01$ & $1.08 E+03$ & $3.48 E+01$ & $1.32 E+03$ \\
\hline$A M A D=3.0 \mathrm{~lm}$ & U.238 & $u-234$ & Th-230 & Ra.226 & $\mathrm{Pb}-210$ & $B i-210$ & Po.210 \\
\hline EFFECT'V & $2.08 E+03$ & $2.33 E+03$ & $3.05 E+03$ & $4.63 E+02$ & $1.90 \mathrm{E}+02$ & $3.25 \mathrm{E}+00$ & $7.26 \mathrm{E}+02$ \\
\hline BOHE & $3.56 E+01$ & $3.98 \mathrm{E}+01$ & $1.57 E+04$ & $6.64 E+02$ & $5.94 E+02$ & $8.98 E-02$ & $2.37 E+02$ \\
\hline AVG. LUNG & $1.70 E+04$ & $1.94 E+04$ & $1.96 \mathrm{E}+06$ & $2.63 \mathrm{E}+03$ & $5.51 E+01$ & 3. $77 \mathrm{E}+01$ & $2.12 E+03$ \\
\hline LIVER & $2.48 \mathrm{E}-01$ & $2.38 E-01$ & $8.61 E+01$ & $4.95 E+01$ & $3.08 E+03$ & $1.69 E+00$ & $2.88 \mathrm{E}+02$ \\
\hline KIONE: & $3.64 \mathrm{E}+0 ?$ & $3.86 E+01$ & $8.73 E+00$ & $1.88 \mathrm{E}+01$ & $1.16 E+03$ & $4.13 E+01$ & $1.49 E+03$ \\
\hline$A M A D=7 . i$ & $U-:$ & $J+236$ & $T h-230$ & $R a-226$ & $\mathrm{~Pb}-210$ & $B i \cdot 210$ & Po. 210 \\
\hline EFFECIIV & $1.11 \mathrm{E}$ & $1.25 E+03$ & $1.85 E+03$ & $3.08 \mathrm{E}+02$ & $2.28 E+02$ & $2.91 E+00$ & $7.61 E+02$ \\
\hline BONE & $3.60 E \cdot U 1$ & $4.02 E+01$ & $1.18 E+04$ & $8.37 E+02$ & $7.46 \mathrm{E}+02$ & $1.27 E-01$ & $3.00 E+02$ \\
\hline AVG.LUNG & $7.50 E+03$ & $8.38 E+03$ & $8.46 E+03$ & $1.14 E+03$ & $6.67 E+01$ & $1.78 E+01$ & $9.16 E+02$ \\
\hline LIVER & $2.30 E-01$ & $2.47 E-01$ & $7.57 E+01$ & $6.37 E+01$ & $3.71 E+03$ & $2.30 E+00$ & $3.52 E+02$ \\
\hline KIDNEY & $3.71 E+01$ & $4.20 E+01$ & $7.71 E+00$ & $2.51 E+01$ & $1.39 E+03$ & $5.34 E+01$ & $1.85 E+03$ \\
\hline$A M A D=54.0 \mathrm{~lm}$ & $u-238$ & $u-234$ & Th-230 & $\mathrm{Ra}-226$ & $\mathrm{~Pb}-210$ & $B i-210$ & Po-210 \\
\hline EFFECTIV & $2.49 E+00$ & $2.74 E+00$ & $5.25 E+02$ & $1.65 E+02$ & $2.17 E+02$ & $1.82 E+00$ & $4.98 E+02$ \\
\hline BOHE & $2.04 E+01$ & $2.28 E+01$ & $6.11 E+03$ & $7.79 E+02$ & $7.13 E+02$ & $1.60 \mathrm{E}-01$ & $2.66 E+02$ \\
\hline AVG.LUNG & $0.00 E+00$ & $0.00 \mathrm{E}+00$ & $0.00 E+00$ & $0.00 E+00$ & $6.38 E+01$ & $0.00 E+00$ & $0.00 E+00$ \\
\hline LIVER & $1.09 E-01$ & $1.40 \mathrm{E}-01$ & $3.92 E+01$ & $5.95 E+01$ & $3.55 E+03$ & $2.53 E+00$ & $3.12 E+02$ \\
\hline KIDNEY & $2.10 E+01$ & $2.38 \mathrm{E}+01$ & $3.99 E+00$ & $2.34 E+C 1$ & $1.32 E+03$ & 4. $75 E+01$ & $1.64 E+03$ \\
\hline AMAD $=0.3 \mathrm{~lm}$ & U-238 & $u-234$ & Ih-230 & $\mathrm{Ra}-226$ & $\mathrm{~Pb}-210$ & $8 i-210$ & Po-210 \\
\hline EFFECIIV & $6.97 \mathrm{E}+03$ & $7.81 E+03$ & $9.06 E+03$ & $18 E+03$ & $1.75 \mathrm{E}+02$ & $6.52 E+00$ & $1,30 E+03$ \\
\hline BOHE & $8.37 E+01$ & $9.35 E+01$ & $4.21 E+04$ & $5.62 E+02$ & $5.39 E+02$ & 4.04E-02 & $1.75 E+02$ \\
\hline AVG. LUNG & $5.84 E+04$ & $6.67 E+04$ & $6.73 E+04$ & $9.03 E+03$ & $5.00 E+01$ & $1.21 E+02$ & $7.29 \mathrm{E}+03$ \\
\hline LIVER & $6.15 E-01$ & $5.35 E-01$ & $2.06 \mathrm{E}+02$ & $3.64 E+01$ & $2.80 E+03$ & $7.62 \mathrm{E}-01$ & $1.98 \mathrm{E}+02$ \\
\hline KIDHEY & $7.03 E \cdot \div$ & $8.55 E+01$ & $2.12 E+0 t$ & $1.43 E+01$ & $1.09 E+03$ & $2.51 E+01$ & $1.10 E+03$ \\
\hline
\end{tabular}


REGION: SAMPLE SITE

MEISE : : MEIEOROLOGIC SIATIOH $\begin{array}{ll}\text { COOE: HILDOS-AREA }(03 / 89) & \text { PAGE } 12 \\ \text { DATA: SAMPLE.DAT } & 04 / 01 / 89\end{array}$

IMGESTION DOSE CONVERSION FACTORS, MREM PER PCI INGESTED

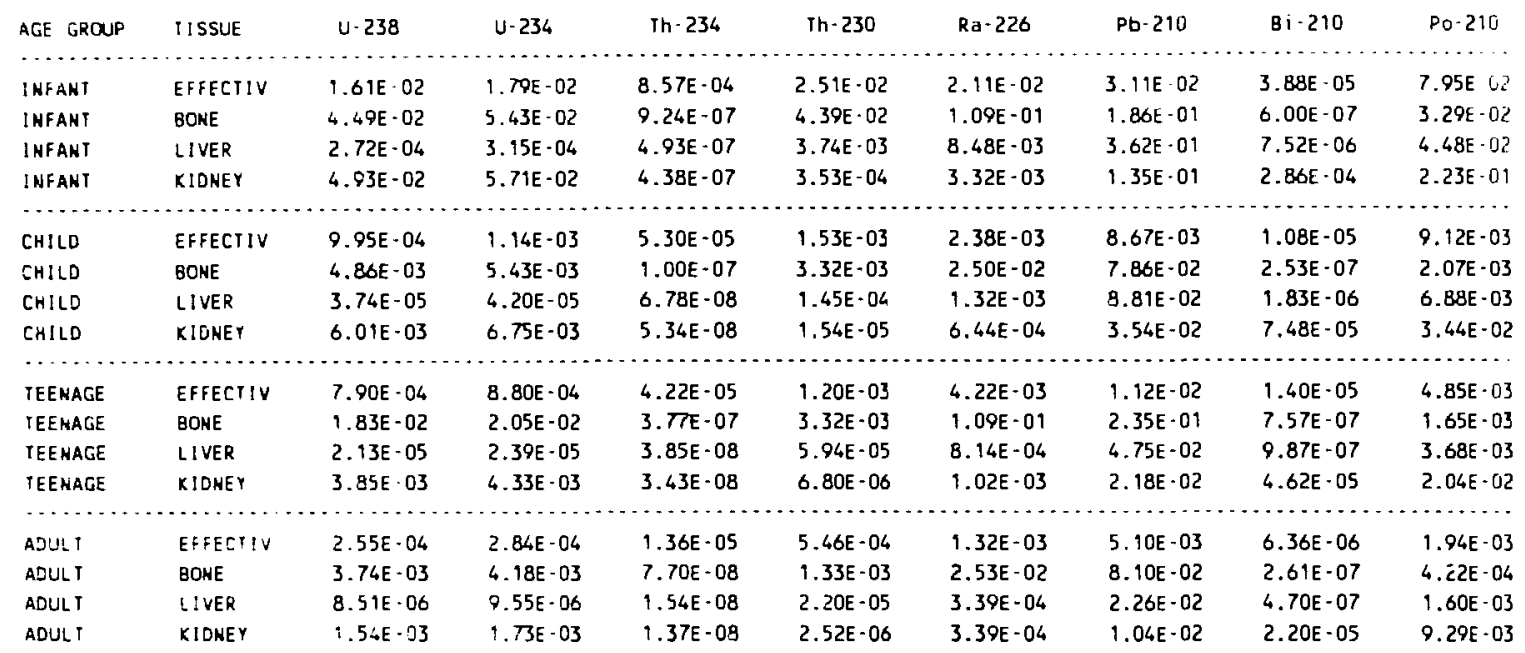

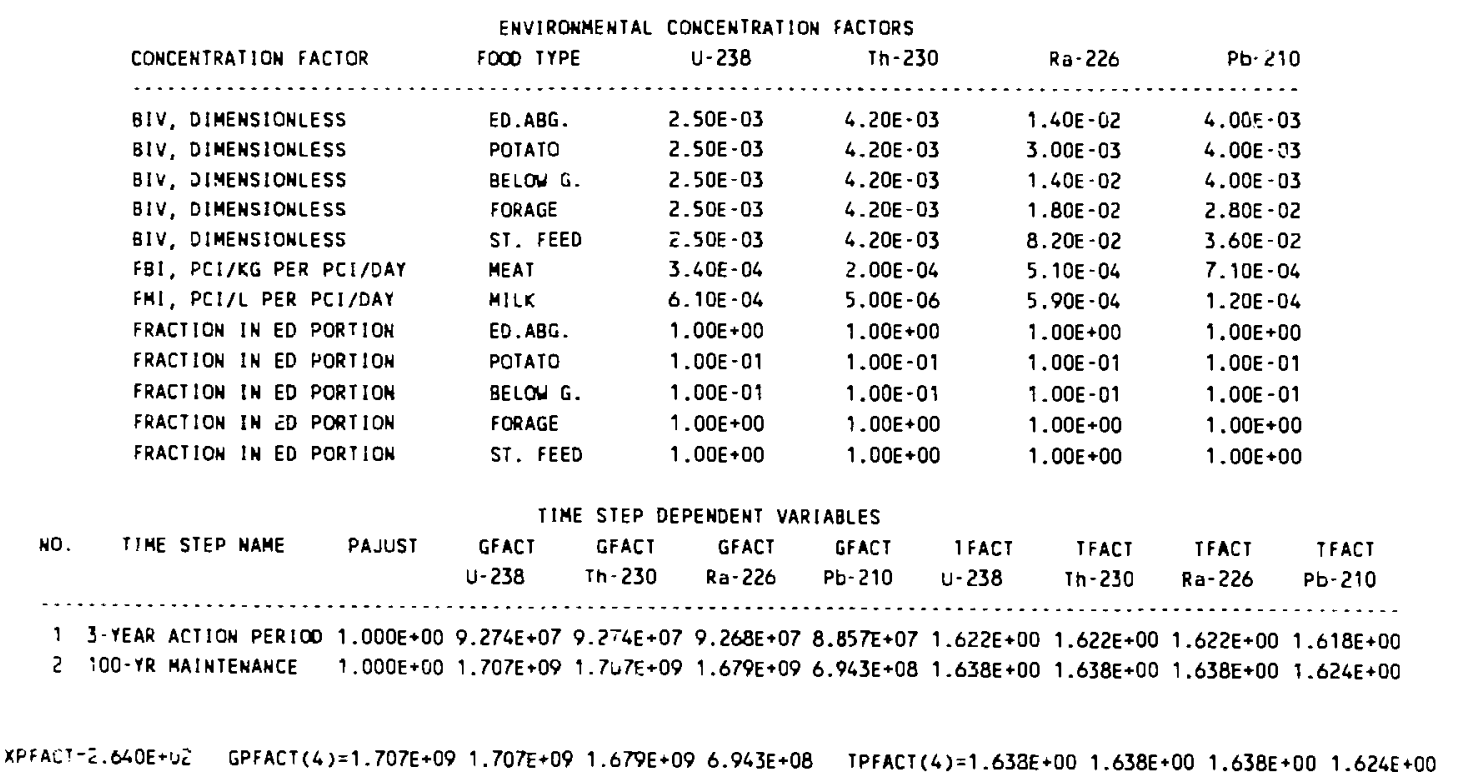


PECION: SAMPLE SITE

ME "TE': METEOROLOG:C STATION
COOE: MILDOS-AREA $(03 / 89)$

IAT: SAMPLE. UAT
PAGE 13

04/01/89

TIME STEP HUMBER 1, 3-TEAR ACTIOH PERIOO

DURATION IH YRS IS ... 3.0

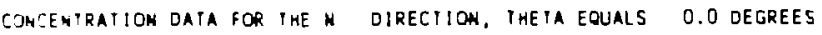

\begin{tabular}{|c|c|c|c|c|c|c|c|c|c|c|}
\hline XAHO, KH & $U \cdot 238$ & in -230 & $\mathrm{Ra}-226$ & $\begin{array}{l}\text { AL AIR C } \\
\text { Pb- } 210\end{array}$ & $R n \cdot 222$ & $\begin{array}{c}\mathrm{PCl} / \mathrm{H3}, \quad A h \\
\mathrm{PO}-218\end{array}$ & $\mathrm{~Pb}-214$ & $\mathrm{Bi} \cdot 214$ & $\mathrm{~Pb} \cdot 210$ & $H L$ \\
\hline 1.5 & $5.2375-04$ & $5.239 E \cdot 04$ & $5.239 E \cdot 04$ & $5,227 E-06$ & $6.857 \mathrm{~T} \cdot 02$ & $6.203 E-02$ & $2.528 E-02$ & $1.052 E-02$ & $8.078 E-09$ & $2.313 E-07$ \\
\hline 2.5 & $2.259 \mathrm{E} \cdot 04$ & $2.25 \mathrm{PE} \cdot 06$ & $2.257 \mathrm{E} \cdot 04$ & $2.254 \mathrm{E} \cdot 04$ & $3.281 E-02$ & $3.117 \mathrm{E}-02$ & $1.649 \mathrm{E}-02$ & $9.40 \mathrm{BE}+03$ & $1.354 E-08$ & $1.508 \mathrm{E} \cdot 07$ \\
\hline 3.5 & $1.169 E-04$ & $1.169 E-36$ & $1.109 E \cdot 04$ & $1.1665-04$ & $1.854 E-02$ & $1.812 E-02$ & $1.145 E-02$ & $7.882 E-03$ & $1.757 \mathrm{E}-08$ & $1.061 E-07$ \\
\hline$\therefore .5$ & $7.289 E-05$ & $7.289 E-05$ & $7.288 E \cdot 05$ & $7.272 E \cdot 05$ & $1.236 E-02$ & $1.223 \mathrm{E}-02$ & $8.544 E-03$ & $6.481 E-03$ & $2.021 E-08$ & 8. $008 E-08$ \\
\hline 7.5 & $2.859 E \cdot 05$ & $2.850 E-0 S$ & $2.859 E \cdot 05$ & $2.853 E \cdot 05$ & $5.577 \mathrm{E} \cdot 03$ & $5.571 E-03$ & $4.512 E-03$ & $3.807 E-03$ & $2.329 E \cdot 08$ & $4.282 E-08$ \\
\hline 15.6 & $8.239 E-06$ & $8.238 E-06$ & $9.238 \mathrm{E} \cdot 06$ & B. $219 E-06$ & $1.960 E \cdot 03$ & $1.961 E-03$ & 1. $805 E-03$ & $1.640 E-03$ & $2.250 E \cdot 08$ & $1.729 \mathrm{E} \cdot 08$ \\
\hline 25.6 & $3.278 E-06$ & $3.278 E \cdot 3 t$ & $3.278 E-06$ & $3.270 E-06$ & $9.124 E \cdot 04$ & $9.129 E-04$ & $8.874 E-04$ & $8.48 \triangle E-04$ & $2.000 E \cdot 08$ & $8.604 E-07$ \\
\hline 350 & $1.791 E-06$ & $1.7915-06$ & $1.791 E-06$ & 1. $.787 E \cdot 06$ & $5.517 E-04$ & $5.520 E-04$ & $5.408 E-04$ & $5.355 E-04$ & $1.807 E \cdot 08$ & $5.338 \mathrm{BE} \cdot 09$ \\
\hline$-5 . ?$ & $1.136 \mathrm{E}-06$ & $1.130 \vec{C} 00$ & $1.135 E \cdot 06$ & $1.133 \mathrm{E}-06$ & $3.776 E-04$ & $3.778 E-04$ & 3. $772 E-04$ & $3.737 \mathrm{E}-0.6$ & $1.657 \mathrm{E} \cdot 08$ & $3.695 E-09$ \\
\hline $5: 5$ & $8.032 E-07$ & $8.032 \mathrm{E} \cdot 37$ & Q.23iE-07 & $8.013 E \cdot 07$ & $2.826 E \cdot 06$ & $2.825 \mathrm{E} \cdot 04$ & $2.830 E-04$ & $2.819 \mathrm{E}-06$ & $1.560 E \cdot 08$ & $2.777 \mathrm{E} \cdot 09$ \\
\hline 35.2 & $5.808 \mathrm{E} \cdot 07$ & $5.365 E \cdot 07$ & 5. $808 \mathrm{~B}-07$ & $5.856 E-07$ & $2.173 E \cdot 04$ & $2.174 E-04$ & $2.182 E \cdot 04$ & $2.181 E-04$ & $1.440 E-08$ & $2.144 E \cdot 09$ \\
\hline 75.2 & HAEIE O? & 4.6. & $4.48: 5 \cdot 07$ & $4.471 E \cdot 07$ & $1.733 \mathrm{E}-04$ & $1.734 E-04$ & $1.742 E-04$ & $1.745 \mathrm{E} \cdot 04$ & $1.356 E-08$ & $1.712 \mathrm{E} \cdot 00$ \\
\hline
\end{tabular}

\begin{tabular}{|c|c|c|}
\hline An IC, KM & $\square-238$ & $\cdot 25=$ \\
\hline$\cdots$ & $\ldots \ldots \ldots$ & \\
\hline$\therefore .5$ & $2.500 E \cdot: 2$ & Z. KOOE-:2 \\
\hline 2.5 & $1.272 \mathrm{E} \cdot .22$ & $9.2 \angle E+22$ \\
\hline 3.5 & $3.682 E+C=$ & $5=8 \mathrm{~g} z \cdot 21$ \\
\hline 4.5 & $4.168 E+01$ & $101=01$ \\
\hline 7.5 & $9.635 E+C 9$ & $1.035 E+01$ \\
\hline 15.0 & $6.711 E+00$ & $4.7^{\prime} 9 E \cdot 70$ \\
\hline 25.0 & 1. B7LE+00 & $1.574 E+70$ \\
\hline 35.0 & $7.024 E+0$. & $\therefore \therefore 24 E+00$ \\
\hline 45.0 & $6.693 E \mathrm{C}$ ? & $0.03 E$ \\
\hline 55.0 & $4.593 \mathrm{E} \cdot \mathrm{C}^{9}$ & $-573 E 5:$ \\
\hline 65.0 & $3.355 \mathrm{E} \mathrm{g}$ & $3755 \mathrm{E} \cdot 04$ \\
\hline 75.2 & $2.5025 \%$ & $\bar{c} \therefore: \because \square$ \\
\hline
\end{tabular}

GROUHD SURFACE CONCEHTRATIOHS, PCI/MC

\begin{tabular}{|c|c|c|c|c|c|c|}
\hline Ra. 226 & Pb-210 & $R \cap-222$ & Po. 218 & Pb- 216 & $81-216$ & $P B-210$ \\
\hline & & & & & & \\
\hline $2.704 E+02$ & $2.994 E-02$ & $0.000 E+00$ & $2.994 E+02$ & $2.994 E+02$ & $2.994 E \cdot 02$ & $2.147 E \cdot 03$ \\
\hline $1.291 E * 02$ & $1.291 E \div 02$ & $0.000 E+00$ & $1.291 E+02$ & $1.291 E+02$ & $1.291 E+02$ & $3.597 E \cdot 03$ \\
\hline $0.678 E+01$ & $6.678 E+01$ & $0.000 E+00$ & $6.679 E+01$ & $6.679 E+01$ & $6.679 E+01$ & $4.668 \mathrm{E} \cdot 03$ \\
\hline 4. $165 \mathrm{E} \cdot 01$ & 4. $165 E=01$ & $0.000 E+00$ & 4. $166 E+01$ & 4. $166 \mathrm{E}+01$ & 4. $166 \mathrm{E}+01$ & $5.370 E \cdot 03$ \\
\hline $1.634 \mathrm{E} \cdot 01$ & $1.634 E+01$ & $0.000 E+00$ & $1.634 E+09$ & $1.634 E+01$ & $1.634 E+01$ & $6.189 E-03$ \\
\hline $4.708 E \cdot 00$ & 6. $708 E \cdot 00$ & $0.000 E+00$ & $4.709 E+00$ & 4.709E +00 & 4. $709 E+00$ & $5.980 E-03$ \\
\hline $1.873 E \cdot 00$ & $1.873 E+00$ & $0.000 E \bullet 00$ & $1.874 E+00$ & $1.874 \mathrm{E}+00$ & $1.874 E+00$ & $5.316 E-03$ \\
\hline $1.023 E \cdot 00$ & $1.023 E+00$ & $0.000 E \cdot 00$ & $1.024 E+00$ & $1.024 E+00$ & $1.024 E+00$ & $4.802 E-03$ \\
\hline $6.489 E-01$ & $6.489 E-01$ & $0.000 E+00$ & $6.492 \mathrm{E}-01$ & $6.492 \mathrm{E} \cdot 01$ & $6.492 E-01$ & 4. $404 E \cdot 03$ \\
\hline 6. $590 \mathrm{E} \cdot 01$ & $4.5900-01$ & $0.000 E+00$ & $4.592 E-01$ & $4.592 E-01$ & $4.592 E-01$ & $4.092 E-03$ \\
\hline $3.353 E \cdot 01$ & $3.353 E-01$ & $0.0 D 0 E+00$ & $3.355 E-01$ & $3.355 E-01$ & $3.355 E-01$ & $3.927 E-03$ \\
\hline $2.56: E-01$ & $2.561 E-01$ & $0.000 E \bullet 00$ & $2.562 E-01$ & $2.562 \mathrm{E}-01$ & $2.562 E-01$ & $3.602 E-03$ \\
\hline
\end{tabular}

\begin{tabular}{|c|c|c|c|c|}
\hline$x=\cdots, K M$ & $U-238$ & $\operatorname{Tn}-230$ & $\mathrm{Ra} \cdot 226$ & $\mathrm{~Pb}-210$ \\
\hline 1.5 & $5.239 E=06$ & $5.239 E \cdot 06$ & 5.2395 .06 & $5.22 \pi \mathrm{E} .06$ \\
\hline 2.5 & $2.259 E-06$ & $2.259 E-06$ & $2.259 E \cdot 06$ & $2.254 E-06$ \\
\hline 3.5 & $1.169 E-06$ & $1.169 \mathrm{E}-0.6$ & $1.169 E-06$ & $1.106 E-06$ \\
\hline$\therefore 5$ & $7.289 E-07$ & $7.289 E-07$ & $7.288 E \cdot 07$ & $7.272 E-07$ \\
\hline 7.5 & $2.859 E-07$ & $2.859 E-07$ & $2.859 E \cdot 07$ & $2.853 E \cdot 07$ \\
\hline 15.5 & $8.239 E-08$ & $8.239 E \cdot 08$ & $8.238 E-08$ & $8.226 E-08$ \\
\hline 25.3 & $3.278 E-08$ & $3.278 E-08$ & $3.278 E-08$ & $3.276 E-08$ \\
\hline 35. & $1.791 E-08$ & $9.791 E \cdot 08$ & i. $791 E-08$ & $1.792 \mathrm{E}-08$ \\
\hline$\therefore 5 .=$ & $\therefore .136 E-08$ & $1.936 E-0 B$ & $1.135 E-08$ & i. $138 E-08$ \\
\hline 55.2 & $8.032 E-09$ & $8.032 E \cdot 05$ & 8.032E-09 & $8.060 E-09$ \\
\hline 55.3 & $5.868 E-69$ & $5.868 E \cdot 07$ & $5.868 E-09$ & $5.897 E-09$ \\
\hline 75,5 & $4.689 E-09$ & 4. $481 E \cdot 97$ & $4.481 E .009$ & $4.511 E \cdot 09$ \\
\hline
\end{tabular}


REIOH: SAM, LE SIIE

ME 'SE 1: METEOROLOGIC SIATIOH
CUOE: MILDOS AREA TOS/BU:

DAIA: SAHPLE. DAI
PACE 17

$04 / 01 / 89$
TIME SIEP NUMBER 1, 3-YEAR ACTIOH PERIOO

EXPOSURE PATHHAT IS INHAL.
DURATIOK IN YRS IS ... 3.0

EXPOSED ORGAH IS EFFECTIV

DOSES SHONN GELON ARE ANHUAL POPULAIION DOSE COMMITMENTS, PERSON-REM PER YEAR

\begin{tabular}{|c|c|c|c|c|c|c|c|c|c|c|c|c|}
\hline & $X R H O$ & XRHO & XRHO & XRHO & XRHO & XRHO & XRHO & KRHO & XRHO & XRHO & XRHO & $X R H O$ \\
\hline IRECIION ION & 1.5 & 2.5 & 3.5 & 4.5 & 7.5 & 15.0 & 25.0 & 35.0 & 45.0 & 55.0 & 65.0 & 75.0 \\
\hline
\end{tabular}

N $\quad 0.396 E-01 \quad 1.379 E-01 \quad 1.000 E-01 \quad 8.011 E-02 \quad 1.349 E-02 \quad 5.588 E-02 \quad 4.253 E-02 \quad 1.851 E-02 \quad 1.700 E-02 \quad 1.365 E-02 \quad 1.216 E-02 \quad 9.294 E-03$

NME $\quad 4.622 E-01 \quad 4.484 E-02 \quad 1.236 E-01 \quad 6.004 E-02 \quad 3.843 E-03 \quad 1.952 E-02 \quad 1.261 E-02 \quad 9.533 E-03 \quad 7.708 E-03 \quad 6.473 E-03 \quad 4.873 E-03 \quad 3.817 E-03$

NE $\quad 2.348 E-01 \quad 1.037 E-015.504 E-02 \quad 6.068 E-03 \quad 6.053 E-03 \quad 9.186 E-03 \quad 5.729 E-03 \quad 4.229 E-03 \quad 3.360 E-03 \quad 2.523 E-03 \quad 1.723 E-03 \quad 1.497 E-03$

EME $\quad 2.283 E-01 \quad 1.123 E-01 \quad 4.661 E-02 \quad 3.631 E-02 \quad 1.938 E-03 \quad 2.126 E-03 \quad 1.360 E-03 \quad 1.934 E-03 \quad 2.722 E-03 \quad 3.015 E-03 \quad 2.407 E-03 \quad 1.925 E-03$

E $\quad 2.664 E-01 \quad 2.818 E-012.042 E-01 \quad 1.646 E-02 \quad 5.602 E-03 \quad 6.598 E-03 \quad 4.457 E-03 \quad 3.443 E-03 \quad 2.828 E-03 \quad 2.457 E-03 \quad 3.287 E-03 \quad 3.589 E-03$

ESE $\quad 2.9 B 2 E-01 \quad 3.314 E-01 \quad 2.466 E-01 \quad 6.055 E-02 \quad 7.079 E-03 \quad 8.563 E-03 \quad 5.891 E-03 \quad 4.591 E-03 \quad 3.795 E-03 \quad 3.314 E-03 \quad 2.887 E-03 \quad 2.565 E-03$

SE $\quad 1.789 E-01 \quad 1.978 E-02 \quad 1.524 E-03 \quad 1.188 E-03 \quad 4.033 E-03 \quad 4.739 E-03 \quad 3.202 E-03 \quad 2.474 E-03 \quad 2.076 E-03 \quad 2.006 E-03 \quad 1.907 E-03 \quad 1.967 E-03$

SSE $\quad 2.002 E-01 \quad 1.871 E-02 \quad 9.036 E-04 \quad 6.783 E-04 \quad 2.156 E-03 \quad 2.359 E-03 \quad 1.524 E-03 \quad 1.148 E-03 \quad 1.152 E-03 \quad 1.225 E-03 \quad 1.051 E-03 \quad 9.208 E-04$

$5 \quad 1.469 E-01 \quad 3.274 E-02 \quad 2.385 E-02 \quad 1.938 E-03 \quad 6.437 E-03 \quad 7.261 E-03 \quad 4.718 E-03 \quad 3.539 E-03 \quad 2.915 E-03 \quad 3.735 E-03 \quad 3.182 E-03 \quad 2.770 E-03$

SSw 2.870E-03 1.584E-03 1.151E-03 8.897E-04 2.959E-03 3.390E-03 3.162E-03 3.246E-03 1.952E-03 1.893E-03 $1.640 E-03 \quad 1.449 E-03$

SH $\quad 2.382 E-03 \quad 1.299 E-03 \quad 0.30 B E-04 \quad 7.116 E-04 \quad 2.314 E-03 \quad 4.00 i E-03 \quad 4.014 E-03 \quad 3.083 E-03 \quad 2.493 E-03 \quad 1.820 E-03 \quad 1.351 E-03 \quad 1.110 E-03$

WSW $\quad 1.03 \mathrm{E}-03 \quad 8.739 \mathrm{E}-04 \quad 6.077 \mathrm{E}-04 \quad 4.546 \mathrm{E}-04 \quad 2.368 \mathrm{E}-03 \quad 3.579 \mathrm{E}-03 \quad 2.301 \mathrm{E}-03 \quad 1.749 \mathrm{E}-03 \quad 1.096 \mathrm{E}-03 \quad 7.564 \mathrm{E}-04 \quad 5.746 \mathrm{E}-04 \quad 4.696 \mathrm{E}-04$

$\Rightarrow \quad 1.205 E-02 \quad 6.419 E-04 \quad 4.324 E-04 \quad 3.158 E-04 \quad 2.795 E-03 \quad 2.258 E-03 \quad 1.432 E-03 \quad 1.093 E-03 \quad 4.043 E-04 \quad 3.298 E-04 \quad 2.870 E-04 \quad 2.547 E-04$

HNH $\quad 8.955 E-03 \quad 4.739 E-04 \quad 3.216 E-04 \quad 2.367 E-04 \quad 1.679 E-03 \quad 1.673 E-03 \quad 9.039 E-04 \quad 6.076 E-04 \quad 4.558 E-04 \quad 2.950 E-04 \quad 1.982 E-04 \quad 1.734 E-04$

NH $\quad 3.057 E-02 \quad 8.353 E-04 \quad 5.803 E-04 \quad 7.344 E-04 \quad 3.171 E-03 \quad 2.412 E-03 \quad 1.473 E \cdot 03 \quad 1.113 E-03 \quad 9.021 E-04 \quad 7.780 E-04 \quad 6.412 E-04 \quad 5.342 E \cdot 06$

HAW $\quad 6.900 E-021.544 E-03 \quad 1.107 E-03$ B.4E4E-04 3.279E-03 5.037E-03 3.314E-03 2.529E-03 2.060E-03 2.110E-03 1.944E-03 1.397E-03

TOTAL DOSE COMHITHENT IS 5.491E+00 PERSON-REM/YR 
REGION: SAMPLE SITE

METSET: METEOROLOGIC STATIOH
COOE : M!LDOS-AREA $(03 / 89)$

DATA: SAMPLE.DAT
PAGE 29

$04 / 01 / 89$

IIME SIEP NUMBER 1, 3-YEAR ACIION PERIOO

DURATION IN YRS 1S... 3.0

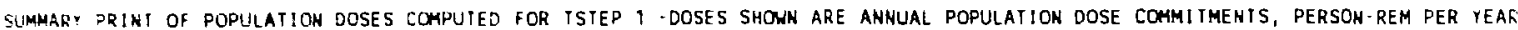

OOSES RECEIVED BY PEOPLE WITHIH 80 KILOMEIERS

\begin{tabular}{|c|c|c|c|c|c|c|}
\hline PATHUAY & EFFECIIV & BONE & AVG.LUHG & 1IVER & KIDNEY & BRONCHI \\
\hline$\cdots$ & $\cdots \cdots$ & $\cdots \cdots$ & $\cdots$ & $\cdots$ & $\cdots$ & - \\
\hline IHHAL. & $5.491 E+00$ & 3. $5 \overline{9} 8 E+01$ & $3.128 E+01$ & $1.306 E+00$ & $9.457 \mathrm{E} \cdot 01$ & $5.184 \mathrm{E}-01$ \\
\hline GROUND & $2.719 E-01$ & $2.719 E-01$ & $2.719 E-01$ & $2.719 E-01$ & $2.719 E-01$ & $2.719 E-01$ \\
\hline Clavo & 1. $892 E \cdot 03$ & $1.892 \mathrm{E}-03$ & $\div .892 E-03$ & $1.892 \mathrm{E}-03$ & $1.892 E-03$ & $1.892 \mathrm{E}-03$ \\
\hline VEG. IHG & $1.061 E+00$ & $1.285 E+01$ & $1.061 E+00$ & $2.979 E+00$ & $2.772 E+00$ & $1.061 E+00$ \\
\hline MEAI IHS & $2.211 E \cdot 02$ & $2.740 E-01$ & $2.211 \mathrm{E}-02$ & $0.756 E-02$ & $5.849 E-02$ & $2.211 E-02$ \\
\hline MILK ING & $6.657 \mathrm{E}-02$ & $5.833 E-01$ & $4.457 \mathrm{E}-02$ & $6.989 E-02$ & $1.066 E-01$ & $4.457 E-02$ \\
\hline RAPLUS50 & $0.000 E+00$ & $0.000 E>00$ & $0.000 E+00$ & $0.000 E+00$ & $0.000 E+00$ & $0.000 E+00$ \\
\hline & & & & & & \\
\hline iciAls & $0.892 E=00$ & $5.206 E-01$ & $3.268 E+01$ & $4.696 E+00$ & $4.156 E+00$ & $1.920 E+00$ \\
\hline
\end{tabular}

DOSES RECE IVED BY PEOPLE BEYONO 80 KLLOMETERS

\begin{tabular}{|c|c|c|c|c|c|c|}
\hline FATHWAT & EFFECI $1 \mathrm{~S}$ & BONE & AVG.LUHG & LIVER & KIDNEY & BRONCHI \\
\hline$\cdots$ & $\ldots \ldots \ldots$ & $\cdots \cdot$ & $\ldots$ & $\ldots \ldots$ & $\cdots$ & $\cdots$ \\
\hline INHAL. & $0.0 C O E+00$ & D. $000 E+00$ & $0.000 E+00$ & $0.000 \mathrm{E} \cdot 00$ & $0.000 \mathrm{E}+00$ & $0.000 E+00$ \\
\hline GROUND & $0.000 E+00$ & $0.000 E+D O$ & $0.000 E+00$ & $0.000 E+00$ & $0.000 E+D 0$ & $0.000 E+00$ \\
\hline CLOND & $0.0, D E+00$ & $0.1000 E+00$ & $0.000 E+00$ & $0.000 E+00$ & $0.000 E+00$ & $0.000 E+00$ \\
\hline VEG. ING & $4.462 E-01$ & $5.605 E+00$ & 4. $462 E-01$ & $1.253 E+00$ & $1.166 \mathrm{E}+00$ & $4.462 E-01$ \\
\hline MEAT ING & $0.000 E-00$ & $0.000 E+00$ & $0.000 E+00$ & $0.000 E+00$ & $0.000 E+00$ & $0.000 E+00$ \\
\hline MILK ING & $0.000 E+0 C$ & $0.000 \mathrm{E} \bullet 00$ & $0.000 E+00$ & $0.000 E+00$ & $0.000 E+00$ & $0.000 E+00$ \\
\hline RHPLUS5O & $5.018 E-03$ & $6.738 E-02$ & $1.120 E-03$ & $5.018 E-03$ & $5.018 E-03$ & $3.519 E-02$ \\
\hline TOTALS & $4.513 E-01$ & $5.472 E=00$ & $4.474 \mathrm{E}-01$ & $1.258 \mathrm{E}+00$ & $1.171 E+00$ & $4.814 E-01$ \\
\hline
\end{tabular}

IOTAL DOSES COMPUTED OVER ALL POPULATIONS

\begin{tabular}{|c|c|c|c|c|c|c|}
\hline PATHWAY & EFFECT!. & BONE & AUG. LUNG & LIVER & KIDHEY & BRONCHI \\
\hline I HHAL. & $5.491 E+00$ & $3.898 E+01$ & $3.128 E+01$ & $1.306 \mathrm{E}+00$ & $9.457 \mathrm{E}-01$ & $5.184 E-01$ \\
\hline GROUND & $2.719 E-01$ & $2.719 E-01$ & $2.719 E-01$ & $2.719 E-01$ & $2.719 E-01$ & $2.719 E-01$ \\
\hline CLOUD & $1.892 E-03$ & $1.892 \mathrm{E}-03$ & $1.892 E \cdot 03$ & $1.892 \mathrm{E}-03$ & $1.892 E-03$ & $1.892 E-03$ \\
\hline VEG. ING & $1.507 \mathrm{E}+00$ & $1.826 E+01$ & $1,507 E \cdot 00$ & $4.231 E+00$ & $3.937 E+00$ & $1.507 E+00$ \\
\hline MEAT IHG & $2.211 \mathrm{E} \cdot 02$ & $2.740 \mathrm{E}-01$ & $2.21: E-02$ & $6.756 E-02$ & $5.849 E-02$ & $2.211 E-02$ \\
\hline HILK IHG & $4.457 E-02$ & $5.833 E-01$ & $4.457 \mathrm{E}-02$ & $6.989 E-02$ & $1.066 \mathrm{E}-01$ & $4.457 \mathrm{E}-02$ \\
\hline RHPLUS50 & $5.018 E \cdot 43$ & $6.738 \mathrm{E}-\mathrm{02}$ & $1.120 E-03$ & $5.018 E-03$ & $5.018 E-03$ & $3.519 E-02$ \\
\hline$\cdots \cdots$ & $\cdots \cdots, \quad \cdots$ & & & & & \\
\hline TUTALS & $7.3 \div+E \cdot 1,0$ & $5.8<4 E+01$ & $3.313 E+01$ & $5.953 E+00$ & $5.327 E+00$ & $2.402 E+00$ \\
\hline
\end{tabular}


REGION: SAMPLE SIIE

METSE?: METEOROLOGIC STATION
COOE: MILDOS-AREA $(03 / 89)$

DATA: SAMPLE.DAT

IIME STEP hUMBER 1, 3-teas aCtION PERIDO
PACE 30

04/01/89

I HOIVIOUAL RECEPTOR PARTICULATE COHCEHTRATIOHS

A!RBORHE CONCEHTRAIIOHS, PCI/M3

\begin{tabular}{|c|c|c|c|c|c|c|c|c|c|c|}
\hline & & & & ORNE CONCEH & ATIOHS, PCI & & & 40 CONCEN & TaHs, PC! & \\
\hline 40. & hame & PISZ & $U-238$ & Ih -230 & $R a-226$ & $P B \cdot 210$ & $U-238$ & in -230 & $\mathrm{Ra} \cdot 226$ & Fo. 210 \\
\hline & & & & & & & & & & \\
\hline • & E RESIDENT & 1 & $0.000 E+00$ & $0.000 E+00$ & $0.000 E+00$ & $0.000 E+00$ & $\overline{0.000 E ~ \$ D O ~}$ & 1. . $000 k+00$ & $0.000 E+00$ & $0.000,50$ \\
\hline$!$ & E RESIDEHT & 2 & $3.386 E \cdot 04$ & $3.396 \mathrm{E}-046$ & $3.386 E-04$ & $3.378 E \cdot 04$ & $1.9365 \cdot 032$ & $1.736 E-02$ & $1.935 E+02$ & $1.935 E \cdot 52$ \\
\hline$Y$ & E RESIDEHT & 3 & $0.000 E+00$ & $0.000 E+00$ & $0.000 E+00$ & $0.000 E+00$ & $0.000 E+00$ & $0.000 E+00$ & $0.000 E \cdot 00$ & $0.000 t+32$ \\
\hline 1 & E RESIDEHT & 4 & $0.000 E+00$ & $0.000 E+00$ & $0.000 E+00$ & $0.000 E+D 0$ & $0.000 E+00$ & C.OCOE $+0 O$ & $0.000 E+00$ & $0.000 E+00$ \\
\hline & COHCENTRATIOH & TOTALS & $3.386 E-04$ & $3.386 E \cdot C 4$ & $3.386 E-04$ & $3.378 E-04$ & $1.936 \mathrm{E}+02$ & $1.936 E \cdot 02$ & $1.935 E+02$ & $1.935 E+02$ \\
\hline & $\ldots \ldots \ldots$ & $\cdots$ & $\cdots$ & & & $\ldots$ & . & - & 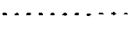 & - \\
\hline 2 & W RESIDENT & 1 & $0.000 E \cdot 00$ & $0.000 E+00$ & $0.000 E+00$ & $0.000 E+00$ & $0.000 E+00$ & $0.000 E+00$ & $0.000 E \cdot 0 O$ & $0.000 E+00$ \\
\hline 2 & W RESIDEHT & 2 & $8.014 E-04$ & $8.014 E-04$ & $8.016 E \cdot 04$ & $7.995 E \cdot 04$ & $-.582 E+02$ & $2.582 E+02$ & $4.570 E+02$ & $4.579 E+0 ?$ \\
\hline 2 & H RESIDEMT & 3 & $0.000 E+00$ & $0.000 E+00$ & $0.000 E+00$ & $0.000 E+00$ & $0.000 E+00$ & $0.000 E \cdot 00$ & $0.000 E \cdot 00$ & $0.000 E+00$ \\
\hline$\Sigma$ & A RESIOENT & 4 & $0.000 E+00$ & $0.000 E+00$ & $0.000 E+00$ & $0.000 E+00$ & $0.000 E * 00$ & $0.000 E+00$ & $0.000 E+00$ & $0.000 E+00$ \\
\hline & ZONCEMIRATIOW & TOIALS & $8.014 E-04$ & $8.014 \mathrm{E} \cdot 04$ & $8.014 E-04$ & $7.995 E-04$ & $4,582 E+02$ & $4.582 E+02$ & $4.579 E+02$ & $4.579 E-02$ \\
\hline & $\ldots \ldots \ldots$ & $-\cdot$ & $\cdots \ldots$ & $\cdots \ldots \ldots$ & 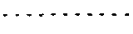 & $\ldots \ldots \ldots$ & $\cdots \ldots \ldots$ & $\cdots \cdots+\cdots$ & $\cdots \cdot$ & $\cdots \ldots \ldots$ \\
\hline 3 & ARESIOENT & $i$ & $3.000 E+00$ & $0.000 E+00$ & $0.000 E+00$ & $0.000 E+00$ & $0.000 E \cdot 00$ & $0.000 E+00$ & $0.000 E+00$ & $0.000 E+00$ \\
\hline 3 & $\therefore$ RESIOENT & 2 & $7.760 E-05$ & $7.760 \mathrm{E}-05$ & 7.76CE-05 & $7.762 \mathrm{E} \cdot 05$ & $4.437 E+01$ & $4.437 E+01$ & $4.434 E \cdot 01$ & $4.4345+01$ \\
\hline$?$ & W RESIDEMT & 3 & $0.000 E+00$ & $0.000 E * 00$ & $0.000 E+00$ & $0.000 E+00$ & $0.000 E \rightarrow 00$ & $0.000 E+00$ & $0.000 E+00$ & $0.000 E+00$ \\
\hline 3 & i RESIDENT & 4 & $0.000 E+00$ & $0.000 E \cdot 00$ & $0.000 E+00$ & $0.000 E+00$ & $0.000 E+00$ & $0.000 E+00$ & $0.000 E+00$ & $0.000 E+00$ \\
\hline & SCHCEMTRATIOH & TOTALS & $7.760 E-05$ & $7.760 E-05$ & $7.760 E-05$ & $7.742 E \cdot 05$ & $6.437 \mathrm{E} \cdot 01$ & $4.437 E+01$ & $4.434 E+01$ & $4.634 E+01$ \\
\hline & $\cdots \cdots, \ldots, \cdots$ & $\cdots$ & $\ldots \ldots \ldots$ & 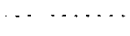 & $\cdots \ldots \ldots$ & $\ldots \ldots \ldots$ & $\ldots \ldots$ & $\cdots \ldots \ldots$ & $\ldots \ldots \ldots$ & $\cdots \ldots \ldots$ \\
\hline$\dot{\square}$ & S RESIOEM & 1 & $5.000 E+00$ & J. ODOE+0O & O. DOOE $\rightleftharpoons 00$ & $0.000 E+00$ & $0.000 E+00$ & $0.000 E+00$ & $0.000 E+00$ & $0.000 E \cdot 00$ \\
\hline- & S RESIOEKT & 2 & $3.585 \mathrm{E}-0$ & $3.585 E-04$ & $3.585 E-04$ & $3.577 \mathrm{E}-06$ & $2.050 E+02$ & $2.050 E+02$ & $2.049 \mathrm{E}+02$ & $2.049 E+02$ \\
\hline- & S RESIOEHT & 3 & $0.000 E+00$ & $0.000 E \cdot 00$ & $0.000 E+00$ & $3.000 E+00$ & $0.000 E+00$ & $0.000 E+00$ & $0.000 E+00$ & $0.00 C E+00$ \\
\hline$\therefore$ & S RESIDENI & 4 & $0.000 E+00$ & $0.000 E+00$ & $0.000 \mathrm{E}+00$ & 0. OOOE .00 & $0.000 E+00$ & $0.000 E \cdot 00$ & $0.000 E+00$ & $0.0 D 0 E-00$ \\
\hline & SCNCENTAATIOA & TOIALS & $3.585 E-0.6$ & $3.585 E-04$ & $3.585 E-04$ & $3.577 \mathrm{E}-04$ & $2.050 E+02$ & $2.050 E+02$ & $2.049 E+02$ & $2.049 E=02$ \\
\hline
\end{tabular}


TELIOH: JAHPLE SITE

METEOROLDCIC SIATION
ZCOE. M!LDOS-AREA $(03 / 80)$

EATA: SAMPLE.DAT

IME STEF NUMBER 1, 3-year aCIION PERIOO
FAGE 31

$04 / 01 / 89$

DURATION IN YRS IS... 3.0

INDIVIOUAL RE?EPIOR RADON ANO RADON OAUGHTER CONCENTRAIIONS

AIRBOKHE CONCENTRATIOHS, PCI/M3

Rn-222 Po-218 PO-216

Bi- 214

Pb- 210

Bi. 210

Po. 210

Wt

GiROUN

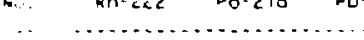

3.345E-02 2.725E-02 8.509E-03 2.885E-03 1.686E-09 1.187E-12 2.411E-17 8.197E-08 2.158E-02 2.158E-02 2.158E-02 4.480E-04

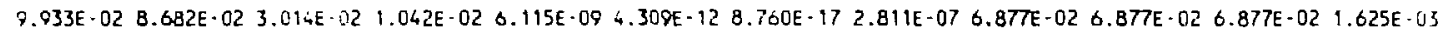

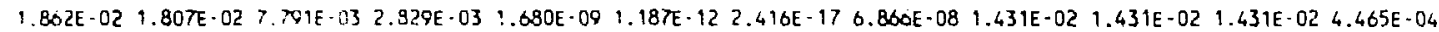

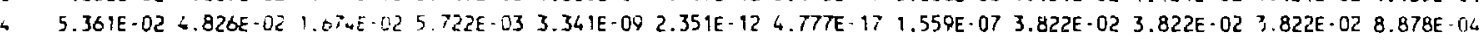




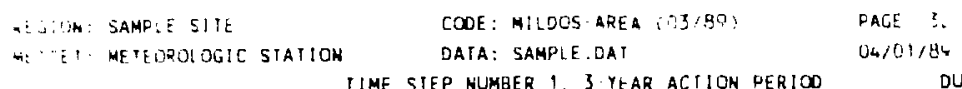
IIME SIEP HUMBER 1, 3.YLAR ACIION PERIDO DURAIION IN PRS IS. $3 .$.

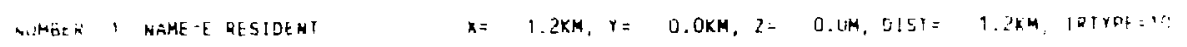

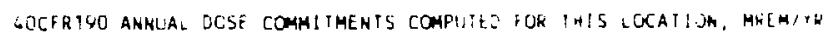

\begin{tabular}{|c|c|c|c|c|c|c|c|}
\hline ACE & PAIHWAY & EFFECIIV & BOHE & AVG.LUNG & LIVER & HINE? & BRONCHI \\
\hline$\ldots \ldots$ & $\cdots \cdots$ & $\cdots$ & $\cdots$ & . & . & . & $\ldots$ \\
\hline I NFANT & IHHAL. & $2.59 E=00$ & $5.84 E=00$ & $2.06 E=01$ & 1. $18 \mathrm{E}+00$ & $\bar{P} 4 \mathrm{E} \cdot 01$ & $0.00 E+01)$ \\
\hline INFANT & GROUNO & $1.20 E-03$ & $1.20 E-03$ & $1.20 \mathrm{E}-03$ & $1.20 \mathrm{E} \cdot 03$ & $1.20 \mathrm{E} \cdot 03$ & $1.20 E-03$ \\
\hline INFAKT & ClOUD & $5.30 E-08$ & $5.30 E \cdot 08$ & $5.30 \mathrm{E} \cdot 08$ & $5.30 E \cdot 08$ & $3.30 E \quad 08$ & $5.30 \mathrm{E} \cdot 08$ \\
\hline IHFANT & VEG. ING & $0.00 E+00$ & $0.00 E-00$ & $0.00 E \cdot 00$ & $0.00 E+00$ & $\therefore \quad A O E+00$ & $0.00 \mathrm{E}, 00 \mathrm{~J}$ \\
\hline INFANT & MEAI ING & $0.00 \mathrm{E}+00$ & $0.00 E \cdot 20$ & $0.00 E+00$ & $0.00 E+00$ & $-\quad U E+00$ & $0.00 E+00$ \\
\hline INFANT & MILK ING & $-.45 E 01$ & $\therefore 43 E \cdot 00$ & $5.15 E \cdot 01$ & $5.15 E \cdot 01$ & $; \quad j 3 E \bullet 00$ & $0.00 E+O C$ \\
\hline$\ldots \cdot \cdots$ & $\ldots \ldots$ & . & $\cdots$ & $\ldots \ldots$ & $\cdots$ & $\ldots$. & $\ldots \ldots$ \\
\hline$\therefore F A N T$ & TOTALS & 3. $-4 t+0 t$ & $728 \mathrm{~F}=00$ & $2.11 t+01$ & $1.70 t \cdot 00$ & $\therefore \quad 2 B E \cdot U D$ & $1.20 E-03$ \\
\hline$\left.A^{\prime}\right\lrcorner E$ & $\because \therefore 41,2=$ & EFFE ' & SONE & AVG IUHG & LIVER & KiUME & BRONCHI \\
\hline & $\cdots \quad \cdots$ & & & $\cdots$ & $\cdots \cdots$ & $\cdots \quad \cdots$ & $\ldots \ldots$ \\
\hline$=\because \therefore D$ & itsint: & $1-1+00$. & $-.93 E+[1 !$ & $2.53 E=20$ & $4.77 E O 1$ & $3.24 E \cdot 01$ & $0.00 E+00$ \\
\hline 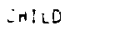 & JROUND & $3 \% 14$ & $1.20 \mathrm{E} \cdot 03$ & $1.20 \mathrm{E} \cdot 03$ & $1.20 E \cdot 03$ & $1.20 \mathrm{DE} \cdot 03$ & $1.20 E \cdot 03$ \\
\hline In:SJ & E:OND & $=30 t \quad a r$ & $5.30 \mathrm{DE}$ & $5.30 E-08$ & $5.30 E a E$ & $5.30 E \cdot 08$ & $5.30 E \cdot 08$ \\
\hline$i n ! \infty$ & JEC. : Hu & 3 ? $1: ?$ & $0.8 / E \quad 01$ & $5.55 t \quad 01$ & $5.55 E 01$ & $4.78 \mathrm{E}-01$ & $0.00 E+00$ \\
\hline$=h: L D$ & MEAT ING & ' SuLE L' & C $3: E \cdot 02$ & B. $60 \mathrm{E} \cdot 02$ & Y. $60 E-02$ & $0 \quad 82 \mathrm{E} \quad 02$ & $0.00 E+00$ \\
\hline$[H] L D$ & MILK :Mũ & $\cdot S E E \quad U_{i}$ & $2.93 E \cup 1$ & $1.16 E \cdot 01$ & 1.10F & $1.55 \mathrm{E} 01$ & $0.00 E+00$ \\
\hline$\cdots \cdots$ & $\cdots \cdots \cdots$ & $\cdots$ & $\ldots \cdot \cdot$ & $\cdot \cdots \cdot \cdot \cdots$ & $\cdot \ldots \ldots$ & $\cdot \ldots \ldots$ & $\ldots \ldots$ \\
\hline ChILD & TOTALS & $1.02 E+00$ & C. OUE.JU & $1.04 t+01$ & $1.24 E \cdot D C$ & $: \quad Z 3 E+O D$ & $1.20 E \cdot 03$ \\
\hline ACE & PATHLAY & $E F t E C T I V$ & BOHE & AVI.LUNG & I IVER & K IDHE & BKC IEH \\
\hline$\ldots \ldots$ & $\ldots \ldots \ldots$ & $\ldots \ldots \ldots$ & 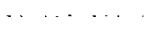 & - & $\ldots \ldots$ & . & 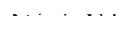 \\
\hline TEEHACE & INHAL. & $8.67 E-01$ & $5.47 E \div 00$ & $6.98 E \cdot 00$ & $2.08 \mathrm{E}-01$ & 1. $03 E-0 ?$ & $0.00 E+00$ \\
\hline TEENAGE & GROUND & $1.20 E \cdot 03$ & $1.20 E-03$ & $1.20 \mathrm{E}-03$ & $1.20 \mathrm{E}-0.3$ & $1.20 E-03$ & $1.20 E \cdot C 3$ \\
\hline IEENACE & CLQUD & $5.30 E \cdot 08$ & $5.30 E-08$ & $5.30 E-08$ & $5.30 E-08$ & $5.30 E \cdot 08$ & $5.30 E \cdot 08$ \\
\hline 'EENACE & VIS. ING & 2.: & $3.70 E+00$ & $4.95 E-01$ & $4.95 E \cdot 01$ & $4.90 E \cdot 01$ & $0.00 E+00$ \\
\hline IEENACE & MEAT ING & $2.05 E-02$ & $4.87 \mathrm{E}-01$ & $7.52 \mathrm{E}-02$ & $7.52 E-02$ & $0.81 E \cdot 02$ & $0.00 E+00$ \\
\hline TEENAGE & MILK INC & $0.17 \mathrm{E} \cdot 02$ & $1.31 E+00$ & $7.48 \mathrm{E}-02$ & $7.48 E-02$ & $1.19 E-01$ & $0.00 E+00$ \\
\hline$\cdots \ldots$ & $\ldots .$. & $\cdot \ldots \ldots$ & $\ldots \ldots \ldots$ & $\cdots \cdots \cdots$ & $\cdots \ldots \ldots$ & $\ldots \ldots$ & $\ldots \ldots$ \\
\hline 'EENACE & TOTALS & 1. $16 k+O C$ & $1.10 E+69$ & $5.63 E+00$ & 8.54E - U1 & $3.41 E \cdot 01$ & $1.20 E 03$ \\
\hline QGE & PAIHWAY & EFFECIIV & DONE & AVG.LUNG & LIVER & R IDHEY & BROHCHI \\
\hline$\cdots$ & $\cdots \ldots$ & . & & . & $\cdot$ & $\cdot$ & $\ldots \ldots$ \\
\hline BDULT & ¿NHD. & $i .33 E-01$ & $5.73 E+0 i$ & $4 . Z 2 E-00$ & 1.72E i i & $1.2+E: 1$ & $0.00 E+0 \mathrm{C}$ \\
\hline$=0 ! j_{L} T$ & CAOUND & $\therefore 20 E-03$ & $i .20 E \cdot 03$ & $1.20 E \quad 03$ & $1.20 \mathrm{E} \quad 0 \mathrm{X}$ & $1.20 \mathrm{DO} 3$ & $1.20 E-03$ \\
\hline AULULT & CLOUD & $530 E \quad 08$ & $5.30 E \cdot 08$ & $5.30 E$ E & $5.30 \mathrm{E}$ GR & $5.30 E \quad 08$ & $5.30 E-c 8$ \\
\hline ADUL I & VEG. ING & $1.25 \mathrm{E} 01$ & $1.5 S E+D G$ & $3.23 \mathrm{E} \quad 01$ & $3.23 \mathrm{E} 01$ & 3. OUE 01 & $0.00 E+60$ \\
\hline ALULI & MEAT INC & $2.14 E-02$ & $\bar{C} \cdot C_{L} \quad C \bar{T}$ & $6.21 E-02$ & $6.21 E \cdot .2$ & $5.46 E \cdot 02$ & $0.00 E \cdot 00$ \\
\hline ADUL: & MILK : HG & $\therefore$ ITE JZ & $\because \quad 7 \in E$ O 1 & $1.85 \mathrm{E} \cdot 02$ & $1.85 \mathrm{E} \cdot 92$ & 2. $\triangle E$ UZ & $0.00 E+00$ \\
\hline 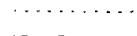 & $\cdots \cdots$ & $\cdots$ & $\cdots \cdots-$ & $\ldots \ldots$ & $\cdots \ldots$ & $\ldots \ldots$ & $\cdots$ \\
\hline$A \bar{L} L L T$ & TOTALS & 2. B?E $\cdot 01$ & $7.10 E+0 S_{1}$ & $4.52 E+00\}$ & 5.7 EE O 1 & $5.13 E 01$ & $1.20 E \cdot 03$ \\
\hline
\end{tabular}




\section{C.4 LISTING OF TEST PROBLEM TESTC1.DAT}

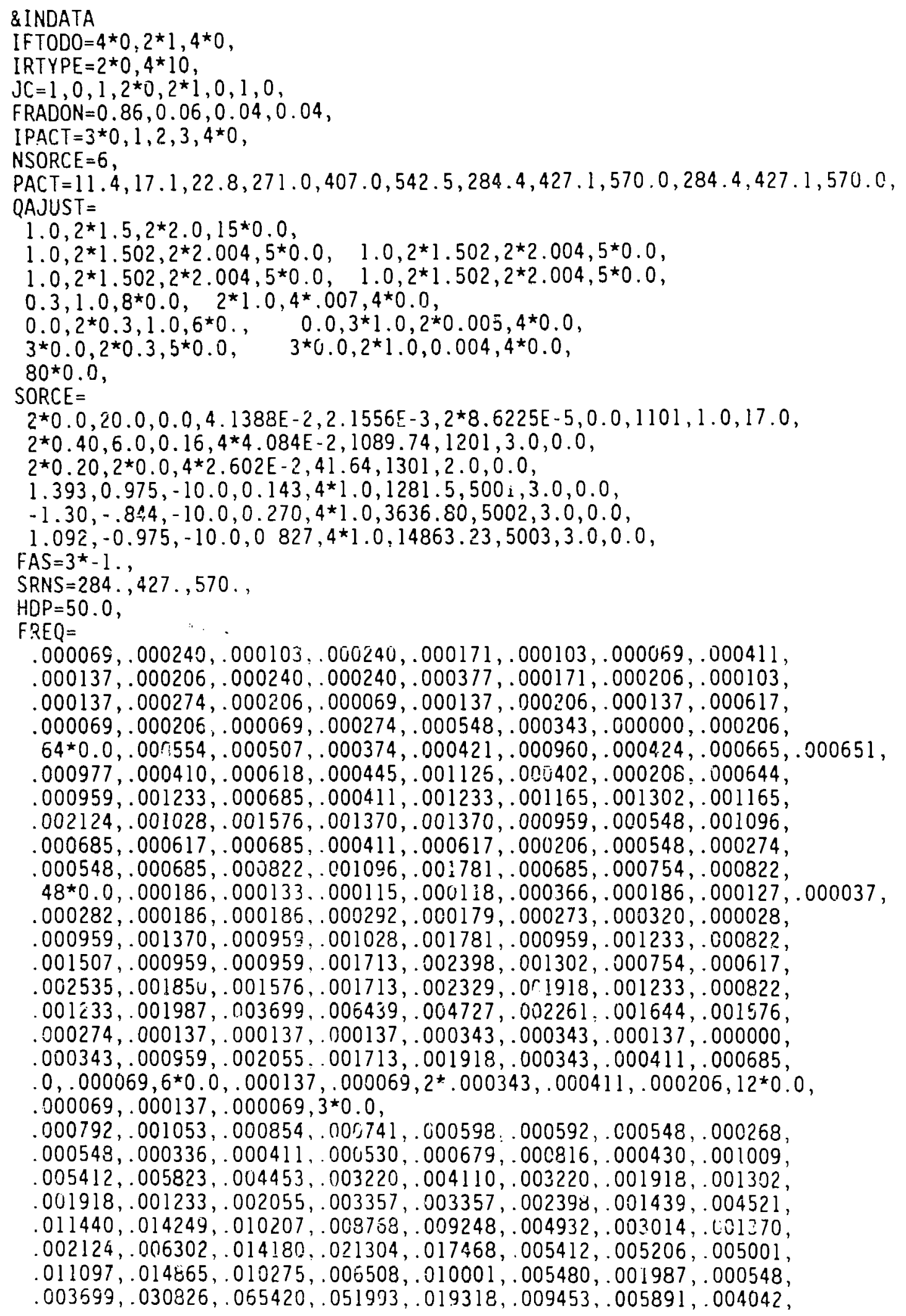


$.002809, .003768, .001713, .000617, .002261, .000822, .000411, .000137$, $.001781, .026716, .050075, .022126, .009248, .004042, .002398, .001028$. $.001028, .001028, .000274, .000000, .000137, .000069, .000000, .000000$, $.000411, .014797, .022469, .009727, .005206, .001165, .000411, .000343$, $.003723, .001668, .001431, .001104, .001608, .001124, .000635, .000583$, $.001221, .001124, .001448, .002996, .005746, .002607, .002023, .002606$, $.011098, .008974, .006439, .005480, .006234, .003563, .003083, .001919$, $.003014, .003152, .005275, .012741, .020140, .009865, .009042, .009933$, $.003425, .003014, .002809, .002877, .004042, .003083, .001165, .000480$, $.000548, .004042, .010892, .028223, .019044, .004042, .002466, .002603$, $144 \star 0.0$,

$D M M=150, D M A=1550$,

FFORI $=0.5, F F O R P=0.5, F H A Y I=0.5, F H A Y P=0.5$,

$F P R=320,1400,230$,

$\mathrm{IPOP}=$

$2 \star 0,1,5,0,15,2 \star 0,4,8,14,400$

$2 * 0,2,3,0,14,0,40,27,10,300,250$,

$2 \star 0,1,2,0,1,0,15,14,4,800,97$,

$2 \star 0,3,4 * 0,10,8,1,327,655$,

$2 * 0,2,1,0,3,0,1.3,0,50,422$.

$2 * 0,1,3,3 * 0,4,2,3 * 0$,

$2 * 0,1,2 * 0,1,0,2,4 * 0$,

$2 \star 0,2,5 \star 0,1,2 \star 0,25893$,

$2 \star 0,4,2,0,1,2 \star 0,10,0,17,37372$,

$2{ }^{\star} 0,3,1,0,1,0,25,4,0,254,0$,

$2{ }^{\star} 0,1,3,0,2,0,8,27,0,322,0$,

$2^{\star} 0,3,2^{\star} 0,1,0,9,6,0,145,0$,

$2 \star 0,2 * 2,4 * 0,3,0,89,0$,

$2 * 0,2 * 1,0,3,0,4,4 * 0$,

$2 \star 0,2,1,3 * 0,5,3 * 0,427$,

$2 * 0,3,1,4 * 0,1,2 \star 0,1000$,

PAJUST $=1.021,1.041,1.063,1.111,1.175,1.206,4 * 0.0$,

IADD $=6$,

$X R E C E P=$

$1.600,-0.200 .8 .8$,

$1.08,-1.6,2.4$,

2. $56,0.0,3.7$,

$2.584,-0.89,-1.4$,

$-0.448,1.466,12.3$,

$2.168,2.168,10.2$,

NSTEP $=6$, TSTART $=1980$, TSTEP $=2.25,2.0,2.25,5.0,8.0,5.0,4 * 0.0$.

ACTRAT $=2.5$,

IPSOL $=3 \star 3,4 * 2$

PTSZ $=1.5,3.0,7.7,54.0,0.3$,

PTSZFC $=0.0,1.0,2{ }^{\star} 0.0,1.0,5 * 0.0,0.3,0.7$,

\section{\&END}

Sierra Madre Mill

Yellowcake Stack

Ore Pad

Grizzly Dump-Hopper

Tailings Area 1

Tailings Area 2

Tailings Area 3

Fence Boundary $E$

Fence Boundary SSE

Grazing $E$

Grazing ESE
Casper Wyoming 


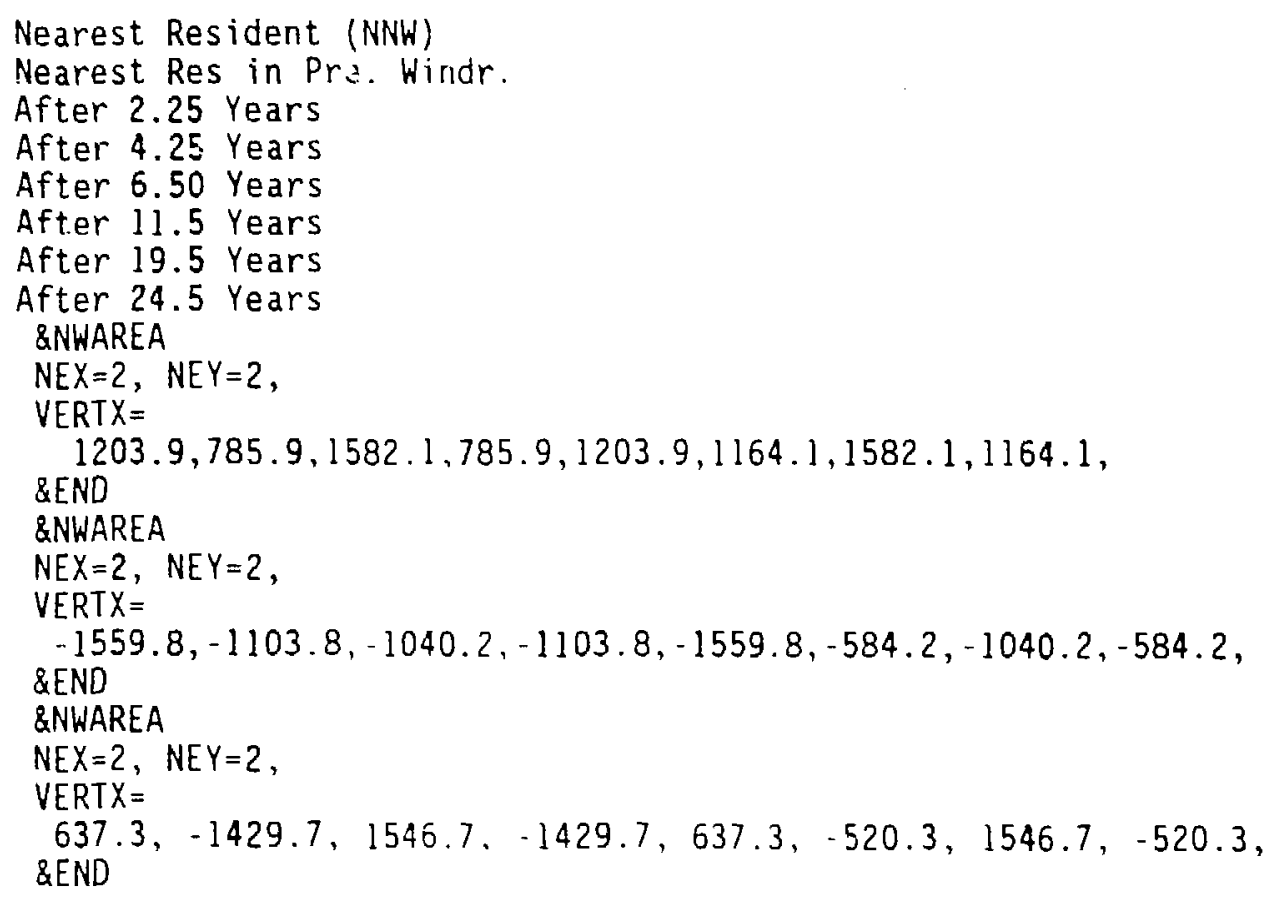




\section{C.5 SELECTED OUTPUT FROM TEST PROBLEM TESTC1.DAT}

REGION: Sierra Madre Mill

METSET: Lasper Hyoming
COOE: MILDOS-AREA $(03 / 89)$

DATA: TESTC1.DAT
PAGE 1

$04 / 18 / 89$

TABLE OF CONTENTS

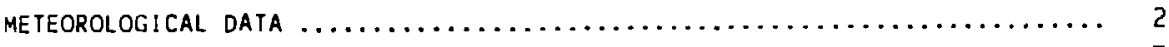

INDIVIDUAL RECEPTORS \& MISCELLANEQUS INPUT DATA $\ldots \ldots \ldots \ldots \ldots \ldots \ldots \ldots \ldots$

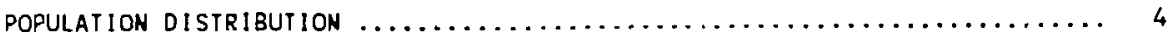

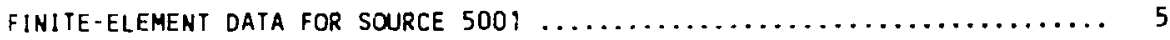

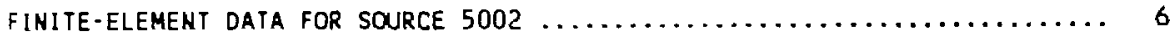

FINITE-ELEMENT DATA FOR SOURCE $5003 \ldots \ldots \ldots \ldots \ldots \ldots \ldots \ldots \ldots \ldots \ldots \ldots \ldots$

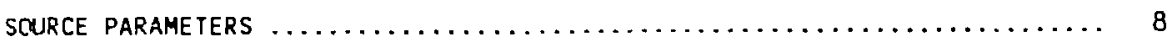

DOSE CONVERSION FACTORS $\ldots \ldots \ldots \ldots \ldots \ldots \ldots \ldots \ldots \ldots \ldots \ldots \ldots \ldots \ldots \ldots$

TIME STEP 1, After 2.25 YearS

CONCENTRATION DATA FOR SPATIAL INTERVALS $\ldots \ldots \ldots \ldots \ldots \ldots \ldots \ldots \ldots \ldots \ldots \ldots \ldots \ldots \ldots \ldots \ldots$

ANNUAL POPULATION DOSE COMMITMENTS, PERSON-REM PER YEAR

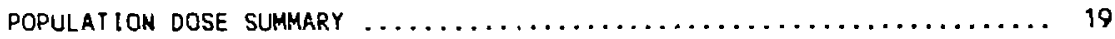

TIME SIEP 2, After 4.25 Years

CONCENTRATION DATA FOR SPATIAL INTERVALS $\ldots \ldots \ldots \ldots \ldots \ldots \ldots \ldots \ldots \ldots \ldots$

AMNUAL POPULATION DOSE COMMITMENTS, PERSON-REM PER YEAR

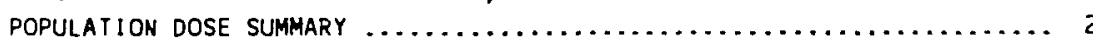

TIME SIEP 3, After 6.50 Years

CONCENTRATION DATA FOR SPATIAL INTERVALS $\ldots \ldots \ldots \ldots \ldots \ldots \ldots \ldots \ldots \ldots \ldots . \ldots \ldots$

ANHUAL POPULATION DOSE COMMITMENTS, PERSON-REM PER YEAR

POPULATION DOSE SUMMARY

TIME STEP 4, After 11.5 Years

CONCENTRATION DATA FOR SPATIAL INTERVALS $\ldots \ldots \ldots \ldots \ldots \ldots \ldots \ldots \ldots \ldots \ldots \ldots$

ANAUAL POPULATION DOSE COMMITM IS, PERSON-REM PER YEAR

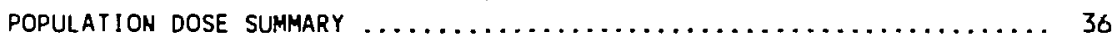

TIME STEP 5, After 19.5 Years

CONCENTRATION DATA FOR SPÄTIAL INTERVALS $\ldots \ldots \ldots \ldots \ldots \ldots \ldots \ldots \ldots \ldots \ldots . \ldots \ldots$

ANMUAL POPULATION DOSE COMMITMENTS, PERSON-REM PER YEAR

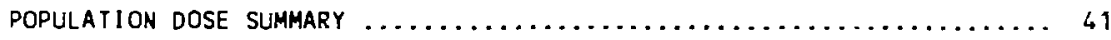

INDIVIDUAL RECEPIOR PARTICULATE CONCENTRATIONS $\ldots \ldots \ldots \ldots \ldots \ldots \ldots \ldots \ldots . .42$

INDIVIDUAL RECEPIOR RADON AND RADON DAUGHTER CONCENTRATIONS $\ldots \ldots \ldots \ldots .43$

INDIVIDUAL RECEPIOR MPC CHECK AND/OR ANNUAL DOSE COMMITMENTS $\ldots \ldots \ldots \ldots .44$

TIME STEP 6, After 24.5 Years

CONCENTRATION DATA FOR SPATIAL INTERVALS $\ldots \ldots \ldots \ldots \ldots \ldots \ldots \ldots \ldots \ldots \ldots . \ldots \ldots$

ANNUAL POPULATION DOSE COMMITMENTS, PERSOH-REM PER YEAR

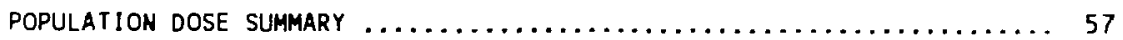

INDIVIDUAL RECEPIOR PARTICULATE CONCENTRATIONS $\ldots \ldots \ldots \ldots \ldots \ldots \ldots \ldots \ldots .58$

INDIVIDUAL RECETTOR RADON AND RADON DAUGHTER CONCENTRATIONS $\ldots \ldots \ldots \ldots \ldots$.

INDIVIDUAL RECEPTOR MPC CHECK AND/OR ANNUAL DOSE COMMITMENTS ......... 60 
Recloh: Sierra Madre Mill

ME iSE I: Casper byoming

COOE: MILDOS-AREA $(03 / 89)$

DATA: IESTCI.DAT

PAGE 2

$04 / 18 / 89$

LOIM: FREOUENCY IN PERCEW DIRECTION IMDICATES WHERE WIMD IS FROM FREOWS $=0.05734,0.21073,0.28176,0.26134,0.13153,0.05734$

MPH H NNE NE EME E ESE SE SSE S SSH SW WSW W WNW NH HNH TOTALS

STABILITY LLASS 1

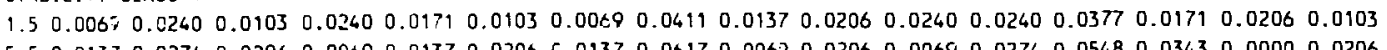

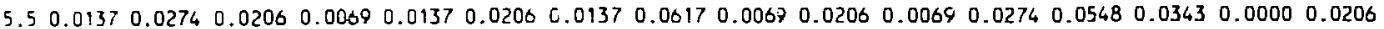

$10.0 \quad 0.0000 \quad 0.0000 \quad 0.0000 \quad 0.0000 \quad 0.0000 \quad 0.0000 \quad 0.0000 \quad 0.0000 \quad 0.0000 \quad 0.0000 \quad 0.0000 \quad 0.0000 \quad 0.0000 \quad 0.0000 \quad 0.0000 \quad 0.0000$

$\begin{array}{lllllllllllllllllll}15.5 & 0.0000 & 0.0000 & 0.0000 & 0.0000 & 0.0000 & 0.0000 & 0.0000 & 0.0000 & 0.0000 & 0.0000 & 0.0000 & 0.0000 & 0.0000 & 0.0000 & 0.0000 & 0.0000\end{array}$

$\begin{array}{lllllllllllllllllllllllll}21.5 & 0.0000 & 0.0000 & 0.0000 & 0.0000 & 0.0000 & 0.0000 & 0.0000 & 0.0000 & 0.0000 & 0.0000 & 0.0000 & 0.0000 & 0.0000 & 0.0000 & 0.0000 & 0.0000\end{array}$

$28.0 \quad 3.0000 \quad 0.0000 \quad 0.0000 \quad 0.00000 .0000 \quad 0.0000 \quad 0.0000 \quad 0.0000 \quad 0.0000 \quad 0.0000 \quad 0.0000 \quad 0.0000 \quad 0.0000 \quad 0.0000 \quad 0.0000 \quad 0.0000$

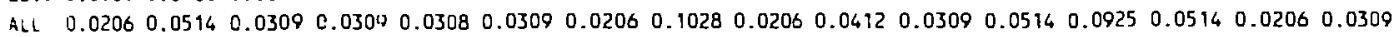

0.3086

0.3698

0.0000

0.0000

0.0000

0.0000

0.6584

sTABIL!IY CLASS 2

$\begin{array}{llllllllllllllllllll} & .5 & 0.0554 & 0.0507 & 0.0374 & 0.0421 & 0.0960 & 0.0424 & 0.0665 & 0.0651 & 0.0977 & 0.0410 & 0.0618 & 0.0445 & 0.1126 & 0.0402 & 0.0208 & 0.0644\end{array}$

$\begin{array}{llllllllllllllllll}5.5 & 0.0959 & 0.1233 & 0.0685 & 0.0411 & 0.1233 & 0.1165 & 0.1302 & 0.1165 & 0.2124 & 0.1028 & 0.1576 & 0.1370 & 0.1370 & 0.0959 & 0.0548 & 0.1096\end{array}$

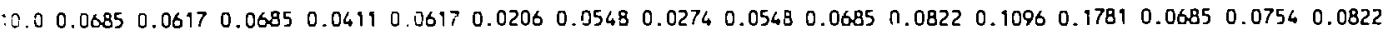

$\begin{array}{llllllllllllllllllll}5.5 & 0.0000 & 0.0000 & 0.0000 & 0.0000 & 0.0000 & 0.0000 & 0.0000 & 0.0000 & 0.0000 & 0.0000 & 0.0000 & 0.0000 & 0.0000 & 0.0000 & 0.0000 & 0.0000\end{array}$

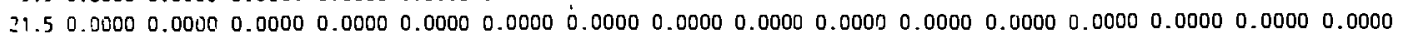

$28.0 \quad 0.0000 \quad 0.0000 \quad 0.0000 \quad 0.0000 \quad 0.0000 \quad 0.0000 \quad 0.0000 \quad 0.0000 \quad 0.0000 \quad 0.0000 \quad 0.0000 \quad 0.0000 \quad 0.0000 \quad 0.0000 \quad 0.0000 \quad 0.0000$

$\begin{array}{llllllllllllllllllllllllllll}\text { ALL } & 0.2198 & 0.2357 & 0.1744 & 0.1243 & 0.2810 & 0.1795 & 0.2515 & 0.2090 & 0.3649 & 0.2123 & 0.3016 & 0.2911 & 0.4277 & 0.2046 & 0.1510 & 0.2562\end{array}$

0.9386

1.8224

1.1236

0.0000

0.0000

0.0000

3.8846

STABILITY CLASS 3

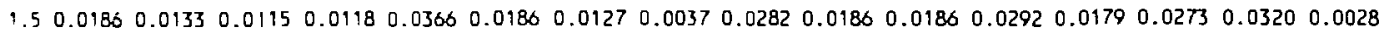

$\begin{array}{llllllllllllllllllllllll}5.5 & 0.0959 & 0.1370 & 0.0959 & 0.1028 & 0.1781 & 0.0959 & 0.1233 & 0.0822 & 0.1507 & 0.0959 & 0.0959 & 0.1713 & 0.2398 & 0.1302 & 0.0754 & 0.0617\end{array}$

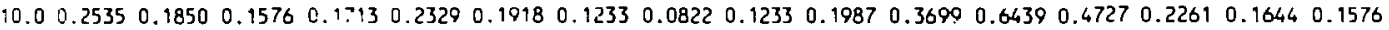

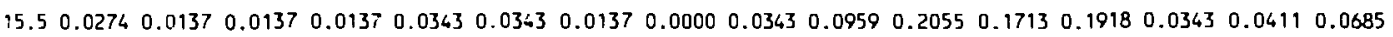

$29.5 \quad 0.0000 \quad 0.00690 .0000 \quad 0.0000 \quad 0.0000 \quad 0.0000 \quad 0.0000 \quad 0.0000 \quad 0.01370 .00690 .03430 .03430 .04110 .0206 \quad 0.0000 \quad 0.0000$

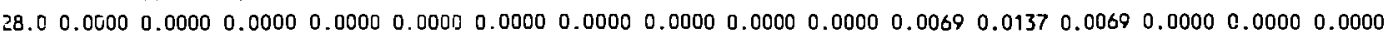

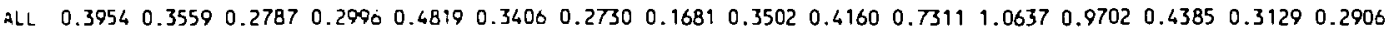

0.3014

1.9320

3.7542

0.9935

0.1578

0.0275

7.1664

STABILIIY CLASS 4

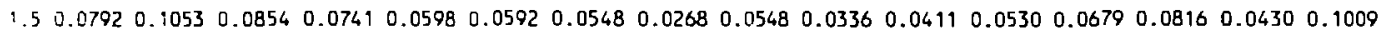

$\begin{array}{lllllllllllllllllllll}5.5 & 0.5412 & 0.5823 & 0.4453 & 0.3220 & 0.4110 & 0.3220 & 0.1918 & 0.1302 & 0.1918 & 0.1233 & 0.2055 & 0.3357 & 0.3357 & 0.2398 & 0.1439 & 0.4521\end{array}$

$\begin{array}{lllllllllllllllllllllll}0.0 & 1.1440 & 1.4249 & 1.0207 & 0.8708 & 0.9248 & 0.4932 & 0.3014 & 0.1370 & 0.2124 & 0.6302 & 1.4180 & 2.1304 & 1.7468 & 0.5412 & 0.5208 & 0.5001\end{array}$

$\begin{array}{lllllllllllllllllllll}15.5 & 1.1077 & 1.4865 & 1.0275 & 0.6508 & 1.0001 & 0.5480 & 0.1987 & 0.0543 & 0.3699 & 3.0826 & 6.5420 & 5.1993 & 1.9318 & 0.9453 & 0.5891 & 0.4042\end{array}$

$\begin{array}{llllllllllllllllllllllllll}21.5 & 0.2809 & 0.3768 & 0.1713 & 0.0617 & 0.2261 & 0.0822 & 0.0411 & 0.0137 & 0.1781 & 2.6716 & 5.0075 & 2.2126 & 0.9248 & 0.4042 & 0.2398 & 0.1028\end{array}$

$\begin{array}{lllllllllllllllllllllllll}28.0 & 0.1028 & 0.1028 & 0.0274 & 0.0000 & 0.0137 & 0.0069 & 0.0000 & 0.0000 & 0.0411 & 1.4797 & 2.2469 & 0.9727 & 0.5206 & 0.1165 & 0.0411 & 0.0343\end{array}$

ALL $\quad 3.2578 \quad 4.0786 \quad 2.7776 \quad 1.9854 \quad 2.6355 \quad 1.5115 \quad 0.7878 \quad 0.3625 \quad 1.0481 \quad 8.021015 .461010 .9037 \quad 5.5276 \quad 2.3286 \quad 1.5775 \quad 1.5944$

1.0205

4.9736

14.0225

25.1403

12.9952

5.7065

63.8586

SAbi_:IY CLASS 5

$\begin{array}{llllllllllllllllllll}1.5 & 0.3723 & 0.1668 & 0.1431 & 0.1104 & 0.1608 & 0.1124 & 0.0635 & 0.0583 & 0.1221 & 0.1124 & 0.1448 & 0.2996 & 0.5746 & 0.2607 & 0.2023 & 0.2608\end{array}$

$\begin{array}{lllllllllllllllllllllll}5.5 & 1.1098 & 0.8974 & 0.6439 & 0.5480 & 0.6234 & 0.3563 & 0.3083 & 0.1919 & 0.3014 & 0.3152 & 0.5275 & 1.2741 & 2.0140 & 0.9865 & 0.9042 & 0.9933\end{array}$

$\begin{array}{llllllllllllllllllllllll}10.0 & 0.3625 & 0.3014 & 0.2809 & 0.2877 & 0.4062 & 0.3083 & 0.1165 & 0.0480 & 0.0548 & 0.4042 & 1.0892 & 2.8223 & i .9044 & 0.4042 & 0.2466 & 0.2603\end{array}$

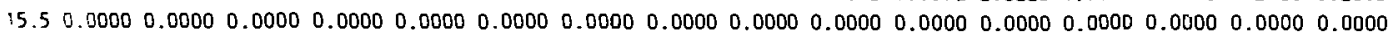

$\begin{array}{llllllllllllllllllllllllllll}21.5 & 0.0000 & 0.0000 & 0.0000 & 0.0000 & 0.0000 & 0.0000 & 0.0000 & 0.0000 & 0.0000 & 0.0000 & 0.0000 & 0.0000 & 0.0000 & 0.0100 & 0.0000 & 0.0000\end{array}$

$\begin{array}{llllllllllllllllllllllll}23.0 & 0.0000 & 0.0000 & 0.0000 & 0.0000 & 0.0000 & 0.0000 & 0.0000 & 0.0000 & 0.0000 & 0.0000 & 0.0000 & 0.0000 & 0.0000 & 0.0000 & 0.0000 & 0.0000\end{array}$

$A L L \quad 1.8246 \quad 1.3656 \quad 1.0679 \quad 0.9461 \quad 1.1884 \quad 0.7770 \quad 0.4883 \quad 0.2982 \quad 0.4783 \quad 0.8318 \quad 1.7615 \quad 4.39604 .4930 \quad 1.6514 \quad 1.3531 \quad 1.5142$

3.1647

11.9952

9.2755

0.0000

$0.000 \mathrm{C}$

0.0000

24.4354

STABILITY CLASS $O$

$\begin{array}{llllllllllllllllllllllllllllllll}1.5 & 0.0000 & 0.0000 & 0.0000 & 0.0000 & 0.0000 & 0.0000 & 0.0000 & 0.0000 & 0.0000 & 0.0000 & 0.0000 & 0.0000 & 0.0000 & 0.0000 & 0.0000 & 0.0000\end{array}$

$\begin{array}{llllllllllllllllllllllllll}5.5 & 0.0000 & 0.0000 & 0.0000 & 0.0000 & 0.0000 & 0.0000 & 0.0000 & 0.0000 & 0.0000 & 0.0000 & 0.0000 & 0.0000 & 0.0000 & 0.0000 & 0.0000 & 0.0000\end{array}$

$\begin{array}{lllllllllllllllllllllllllll}10.0 & 0.0000 & 0.0000 & 0.0000 & 0.0000 & 0.0000 & 0.0000 & 0.0000 & 0.0000 & 0.0000 & 0.0000 & 0.0000 & 0.0000 & 0.0000 & 0.0000 & 0.0000 & 0.0000\end{array}$

$\begin{array}{lllllllllllllllllllllllll}15.5 & 0.0000 & 0.0000 & 0.0000 & 0.0000 & 0.0000 & 0.0000 & 0.0000 & 0.0000 & 0.0000 & 0.0000 & 0.0000 & 0.0000 & 0.0000 & 0.0000 & 0.0000 & 0.0000\end{array}$

$\begin{array}{lllllllllllllllllllllllllll}21.5 & 0.0000 & 0.0000 & 0.0000 & 0.0000 & 0.0000 & 0.0000 & 0.0000 & 0.0000 & 0.0000 & 0.0000 & 0.0000 & 0.0000 & 0.0000 & 0.0000 & 0.0000 & 0.0000\end{array}$ $\begin{array}{lllllllllllllllllllllllllll}28.0 & 0.0000 & 0.0000 & 0.0000 & 0.0000 & 0.0000 & 0.0000 & 0.0000 & 0.0000 & 0.0000 & 0.0000 & 0.0000 & 0.0000 & 0.0000 & 0.0000 & 0.0000 & 0.0000\end{array}$ ALL $\quad 0.0000 \quad 0.0000 \quad 0.0000 \quad 0.0000 \quad 0.0000 \quad 0.00000 .0000 \quad 0.0000 \quad 0.0000 \quad 0.0000 \quad 0.0000 \quad 0.0000 \quad 0.0000 \quad 0.0000 \quad 0.0000 \quad 0.0000$

0.0000

0.0000

0.0000

0.0000

0.0000

0.0000

0.0000

ALL $\quad 5.7182 \quad 6.0872 \quad 4.3295 \quad 3.3863 \quad 6.6176 \quad 2.8395 \quad 1.8212 \quad 1.1606 \quad 2.2621 \quad 9.522318 .286116 .705911 .51104 .6745 \quad 3.41513 .6863 \quad 100.0034$ 
REglan: Sicria Madre hill MET TE T : Casper Wyoming
COOE: HILDOS-AREA (03/89) DATA: TESTC1.OAT
PAGE 3

$04 / 18 / 89$

\begin{tabular}{|c|c|c|c|c|c|c|c|c|c|c|c|c|c|}
\hline 1 & T.OCATION NAMES & $X(K M)$ & $Y(K H)$ & $2(M)$ & DISI (KM) & IYPE & 1 & LOCATION MAMES & $X(K M)$ & $Y(K M)$ & $Z(M)$ & $0 \mid S T(K M)$ & IYPE \\
\hline 1 & Fince Boundary E & 1.60 & -0.20 & 8.80 & 1.61 & 0 & 4 & Grazing ESE & 2.58 & -0.88 & -1.40 & 2.73 & 10 \\
\hline 2 & Fence 8oundary SSE & 1.08 & -1.60 & 2.40 & 1.93 & 0 & 5 & Hearest Resident (HH & -0.45 & 1.47 & 12.30 & 1.53 & 10 \\
\hline 3 & Grazing $E$ & 2.56 & 0.00 & 3.70 & 2.56 & 10 & 6 & Mearest Res in Pre. & 2.17 & 2.17 & 10.20 & 3.07 & 10 \\
\hline
\end{tabular}

MISCELLAMEOUS IHPUTABLE PARAMETER VALUES

\begin{tabular}{|c|c|c|c|c|c|c|c|c|c|c|}
\hline DMM & DMA & ISTART & FFORI & FHAYI & F FORP & FHAYP & $\operatorname{FPR}(1)$ & FPR(2) & FPR (3) & ACIRAT \\
\hline 150.0 & 1550.0 & 1980.00 & 0.50 & 0.50 & 0.50 & 0.50 & 320.00 & 1400.00 & 230.00 & 2.50 \\
\hline
\end{tabular}

IPACT EQUALS $0,0,0,1,2,3$,

Je equals $1,0,1,0,0,1,1,0,1,0$

$\begin{array}{rrcc}\text { IIME SIEP DATA... } & \text { STEP NAMES } & \text { LENGTH, YRS } & \text { IFIDOO } \\ \text { 1 After } 2.25 \text { Years } & 2.25 & 0 \\ 2 \text { After } 4.25 \text { Years } & 2.00 & 0 \\ 3 \text { After } 6.50 \text { Years } & 2.25 & 0 \\ 4 \text { After } 11.5 \text { Years } & 5.00 & 0 \\ 5 \text { After } 19.5 \text { Years } & 8.00 & 1 \\ 6 \text { After } 24.5 \text { rears } & 5.00 & 1\end{array}$

XRHO EQUALS $\quad 1.5, \quad 2.5,3.5,6.5,7.5,15.0,25.0,35.0,45.0,55.0,65.0,75.0$

HDP EOUALS 50.0 
REGION: Sierra Madre Mill METSET: Casper Wyoming
COOE: HILOOS-AREA (03/89) DATA: IESTC1.DAT
PAGE 4

$04 / 18 / 89$

POPULATION DISTRIBUTION

\begin{tabular}{|c|c|c|c|c|c|c|c|c|c|c|c|c|c|c|c|c|}
\hline KILOHETERS & 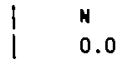 & $\begin{array}{r}\text { HME } \\
22.5\end{array}$ & $\begin{array}{c}\text { ME } \\
45.0\end{array}$ & $\begin{array}{r}\text { ENE } \\
67.5\end{array}$ & $\begin{array}{c}E \\
90.0\end{array}$ & $\begin{array}{r}\text { ESE } \\
112.5\end{array}$ & $\begin{array}{c}\text { SE } \\
135.0\end{array}$ & $\begin{array}{r}\text { SSE } \\
157.5\end{array}$ & $\stackrel{S}{180.0}$ & $\begin{array}{r}\text { SSW } \\
202.5\end{array}$ & $\begin{array}{c}\text { SH } \\
225.0\end{array}$ & $\begin{array}{r}\text { HSH } \\
247.5\end{array}$ & $\begin{array}{c}H \\
270.0\end{array}$ & $\begin{array}{r}\text { WWW } \\
292.5\end{array}$ & $\begin{array}{c}\text { NH } \\
315.0\end{array}$ & $\begin{array}{r}\text { NHW } \\
337.5\end{array}$ \\
\hline $1.0 \cdot 2.0$ & 0 & 0 & 0 & 0 & 0 & 0 & 0 & 0 & 0 & 0 & 0 & 0 & 0 & 0 & 0 & 0 \\
\hline $2.0-3.0$ & $i$ & 0 & 0 & 0 & 0 & 0 & 0 & 0 & 0 & 0 & 0 & 0 & 0 & 0 & 0 & 0 \\
\hline $3.0 \cdot 4.0$ & $i$ & 2 & 1 & 3 & 2 & 1 & 1 & 2 & 4 & 3 & 1 & 3 & 2 & 1 & 2 & 3 \\
\hline $4.0 \cdot 5.0$ & $i$ & 3 & 2 & 0 & 1 & 3 & 0 & 0 & 2 & 1 & 3 & 0 & 2 & 1 & 1 & 1 \\
\hline $5.0-10.0$ & 0 & 0 & 0 & 0 & 0 & 0 & 0 & 0 & 0 & 0 & 0 & 0 & 0 & 0 & 0 & 0 \\
\hline $10.0 \cdot 20.0$ & 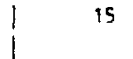 & 16 & 1 & 0 & 3 & 0 & 1 & 0 & 1 & 1 & 2 & 1 & 0 & 3 & 0 & 0 \\
\hline $20.0-30.0$ & i & 0 & 0 & 0 & 0 & 0 & 0 & 0 & 0 & 0 & 0 & 0 & 0 & 0 & 0 & 0 \\
\hline $30.0 \cdot 40.0$ & 1 & 40 & 15 & 10 & 1 & 4 & 2 & 0 & 0 & 25 & 8 & 9 & 0 & 4 & 5 & 0 \\
\hline $40.0 \cdot 50.0$ & 1 & 27 & 14 & 8 & 3 & 2 & 0 & 1 & 10 & 4 & 27 & 6 & 3 & 0 & 0 & 1 \\
\hline $50.0-60.0$ & 1 & 10 & 4 & 1 & 0 & 0 & 0 & 0 & 0 & 0 & 0 & 0 & 0 & 0 & 0 & 0 \\
\hline $60.0 \cdot 70.0$ & 1 & 300 & 800 & 327 & 50 & 0 & 0 & 0 & 17 & 254 & 322 & 145 & 89 & 0 & 0 & 0 \\
\hline $70.0 \cdot 80.0$ & 1400 & 250 & 97 & 655 & 422 & 0 & 0 & 25893 & 37372 & 0 & 0 & 0 & 0 & 0 & 427 & 1000 \\
\hline
\end{tabular}

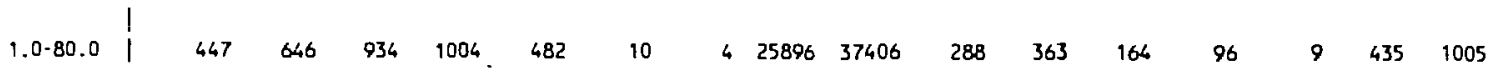

TOTAL 1 -80 KH POPULATION IS 69189 PERSONS 
SEzION: Sictra Modre mill

HEISET: Ca:Der Hyoming
COOE: MILDOS-AREA $(03 / 89)$

DATA: TESICI.DAT
PAGE 5

$04 / 18 / 89$

FINITE ELEMENT DAIA FOR SOURCE NO. $4:$ : $P X=1$ ID $=5001$

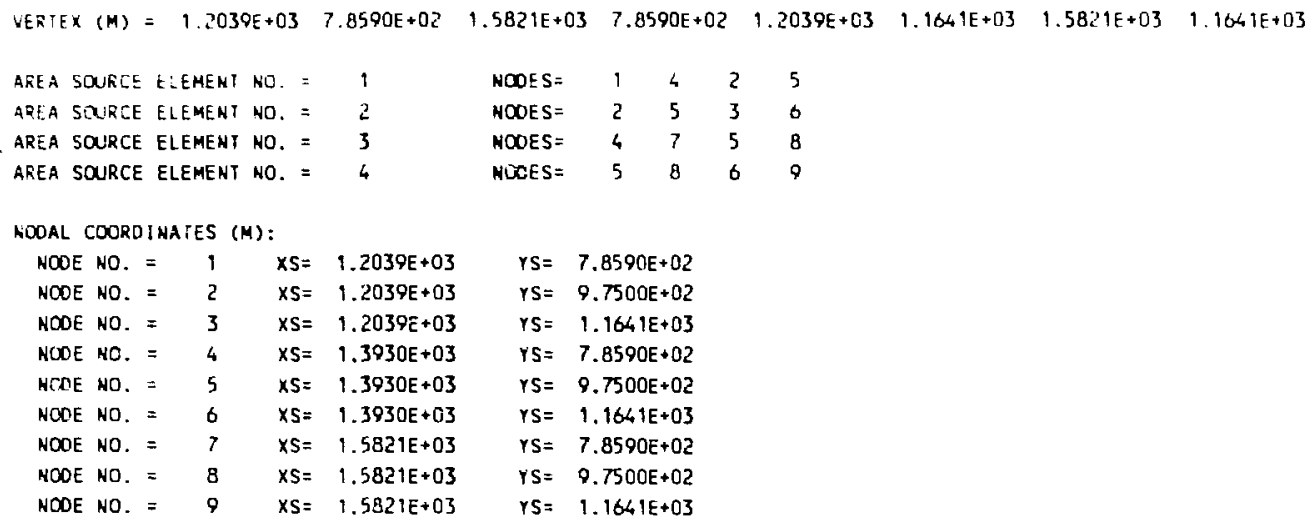


REGION: Sierra Madre mill

MEISEI: Casper worning
COOE: HILDOS-AREA (03/89)

DAIA: IESICI.DAT
PAGE 6

$04 / 18 / 89$

F!HITE ELEMEMT DATA FOR SCURCE HO. $S$ :

$I P X=2 I D=5002$

VERTEX (M) $=-1.5598 E+03 \cdot 1.1038 E+03 \cdot 1.0402 E+03 \cdot 1.1038 E+03 \cdot 1.5598 E+03-5.8420 E+02-1.0402 E+03-5.8420 E+02$

AREA SOURCE ELEMEHT NO. = I

AREA SOURCE ELEMENT NO. = $?$

AREA SOURCE ELEMEHT HO. = 3

AREA SOURCE ELEMENT NO. = 4

$\begin{array}{lllll}\text { MOOES }= & 1 & 4 & 2 & 5 \\ \text { MOOES }= & 2 & 5 & 3 & 6 \\ \text { HOOE } S= & 4 & 7 & 5 & 8 \\ \text { HOOES }= & 5 & 8 & 6 & 9\end{array}$

HOOAL COORDIMATES (M):

NOOE HO. $=1$

HOOE NO. $=2$

$X S=-1,5598 E+03$

$Y S=-1.103 B E+03$

$x 5=-1.5598 E+03$

$X S=-1.5598 E+03$

HOOE NO. $=4 \quad X S=-1.3000 E+03$

NOOE HO. $=5 \quad X S=-1.3000 E+03$

HOOE NO. $=6 \quad \times S=-1.3000 E+03$

NOOE NO. $=7 \quad \times 5=-1.0402 E+03$

NOOE NO. $=8 \quad X S=-1.0402 E+03$

NOOE NO. $=0 \quad X S=-1.0602 E+03$

$Y S=-8.4400 E+02$

$Y S=-5.8420 E+02$

$Y S=-1.1038 E+03$

$Y S=-8.4400 E+02$

$Y S=-5.8420 E+02$

$Y S=-1.103 B E+03$

$Y S=-8.4400 E+02$

$Y S=-5.8420 E+02$ 
REGION: Sierra Madre Mill

MEISET: Casper Hyoming
COOE : HILDOS -AREA (03/89)

DATA: IESTCI.DAI
FAGE 7

$04 / 18 / 89$

FINITE ELEMENT DATA FOR SOURCE NO, 6: IPX= 3 ID= 5003

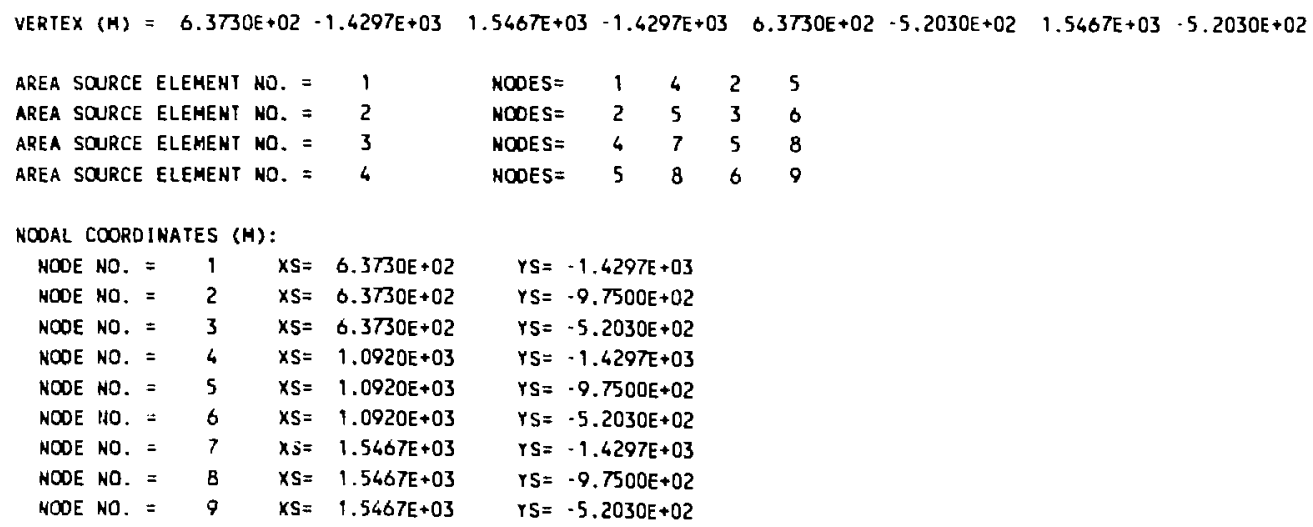


REjIOh: Slerra Madre Mil!

METSE: : Casper WyOMng
COCE: HILDUS-AREA $(03 / 89)$

DAIA: IESICI.DAT
PAGE 8

$04 / 13 / 89$

HUHBER OF SOURCES $=6$

\begin{tabular}{|c|c|c|c|c|c|c|c|c|c|c|c|c|c|}
\hline & $X M$ & K.M & $M$ & KH2 & & & CI/YEAR & & & & PSILE & M/SEC & \\
\hline . & $x$ & r & 2 & AREA & 1.238 & In-230 & $R a=226$ & $P b-210$ & $R_{n}=222$ & 10 & SET & EXIT VEL & SOURCE HAME \\
\hline 1 & 0.00 & 0.00 & 20.00 & 0.0000 & 4. I- $E-02$ & $2.16 E-03$ & $8.62 E-05$ & $8.62 E-05$ & $0.00 E+00$ & 1101 & 1 & $1.70 E+01$ & Yellowcake Stack \\
\hline 2 & 0.40 & 0.40 & 6.00 & 0.1600 & $4.08 E-02$ & $4,08 E-02$ & $4.08 E-02$ & $4.08 E-02$ & $1.09 E+03$ & 1209 & 3 & $0.00 \mathrm{E}+00$ & Ore Pad \\
\hline 3 & 0.20 & 0.20 & 0.00 & 0.0000 & $2.60 \mathrm{E}-02$ & $2.60 \mathrm{E}-02$ & $2.60 \mathrm{E}-02$ & $2.60 E-02$ & $4.16 E+01$ & 1301 & 2 & $0.005+00$ & Grizzly Dump-Hoppe \\
\hline 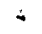 & 1.30 & 0.98 & -10.00 & 0.1430 & $5.67 E-03$ & $1.35 E-01$ & $1.41 E-01$ & $1.41 E-01$ & $1.28 E+03$ & 5001 & 3 & $0.00 \mathrm{E}+00$ & Tailings Area 1 \\
\hline 5 & .1 .30 & -0.84 & -10.00 & 0.2700 & $1.61 E-02$ & $3.82 E-01$ & $4.01 E-01$ & $4.01 E-01$ & $3.64 E+03$ & 5002 & 3 & $0.00 E+00$ & Tailings Area 2 \\
\hline 0 & 1.20 & .0 .78 & -10.00 & 0.8270 & $6.5 B E-02$ & $1.56 E+00$ & $1.64 E+110$ & $1.64 E+00$ & $1.49 E+04$ & $500 ?$ & 3 & $0.00 E+D 0$ & Tailings Area 3 \\
\hline
\end{tabular}

INPUT TAILS ACIIVITIES, PCI/G

$\begin{array}{ccccc}\text { SEI URAHIUM } & \text { THORIUM } & \text { RAJIUH } & \text { LEAD } \\ \ldots \ldots \ldots \ldots \ldots \ldots \ldots \ldots \ldots \ldots & \ldots \ldots \ldots \ldots \ldots \ldots \\ 1 & 1.14 E+01 & 2.71 E+02 & 2.84 E+02 & 2.84 E+02 \\ 2 & 1.71 E+01 & 4.07 E+02 & 4.27 E+02 & 4.27 E+02 \\ 3 & 2.28 E+01 & 5.43 E+02 & 5.70 E+02 & 5.70 E+02\end{array}$

AMAD AHO FRACTIOHAL DISTRIBUTIOH

$\begin{array}{lcccc}\text { SEI } & 1.5 & 3.0 & 7.7 & 54.0 \\ \ldots \ldots \ldots & \ldots \ldots \ldots \ldots \ldots \ldots \\ 1 & 0.000 & 1.000 & 0.000 & 0.000 \\ 2 & 1.000 & 0.000 & 0.000 & 0.000 \\ 3 & 0.000 & 0.000 & 0.300 & 0.700\end{array}$

\begin{tabular}{|c|c|c|c|c|c|c|c|c|c|c|}
\hline & & PART!CULATE & SQURCE STR & IH MULII & RS BY TIME & SIEP, 6 TIME & STEP(S) & D FOR THI & FUK & \\
\hline SOURCE & ISIEP I & TSTEP 2 & ISTEP 3 & TSIEP 4 & ISIEP 5 & TSTEP 6 & TSTEP 7 & ISIEP 8 & TSTEP $Q$ & ISIEP 10 \\
\hline UMEER & $2.25 \times R S$ & 2.00YRs & $2.25 Y R S$ & $5.00 Y R 5$ & 8.00 YRS & 5. OOYRS & 0.00 YRS & 0.00 YRS & 0.00 YRS & 0.0 YYRS \\
\hline 1 & $1.000 E+00$ & $1.500 E+00$ & $1.500 E+00$ & $2.000 E+00$ & $2.000 E+00$ & $0.000 E+00$ & $0.000 E+00$ & $0,000 E+00$ & $0.000 E+00$ & $0.000 E+00$ \\
\hline 2 & $1.000 E+00$ & $1.502 E+00$ & $1.502 E+00$ & $2.004 E+00$ & $2.004 E+00$ & $0.000 E+00$ & $0.000 E+00$ & $0.000 E+00$ & $0.000 E+00$ & $0.000 E+00$ \\
\hline 3 & $1.000 E+00$ & $1.502 \mathrm{E}+00$ & $1.502 E+00$ & $2.004 E+00$ & $2.004 E+00$ & $0.000 \varepsilon+00$ & $0.000 E+00$ & $0.000 E+00$ & $0.000 E+00$ & $0.000 E+00$ \\
\hline 4 & $3.000 E-01$ & $1.000 E+00$ & $0.000 E+00$ & $0.000 E+00$ & $0.000 E+00$ & $0.000 E+00$ & $0.000 \mathrm{E}+00$ & $0.000 E+00$ & $0.000 E+00$ & $0.000 E+00$ \\
\hline 6 & $0.000 E+00$ & $0.000 E+00$ & $0.000 E+00$ & $3.000 E-01$ & $3.000 E-01$ & $0.000 E+00$ & $0.000 E+00$ & $0.000 E+00$ & $0.000 E+00$ & $0.000 E+00$ \\
\hline
\end{tabular}

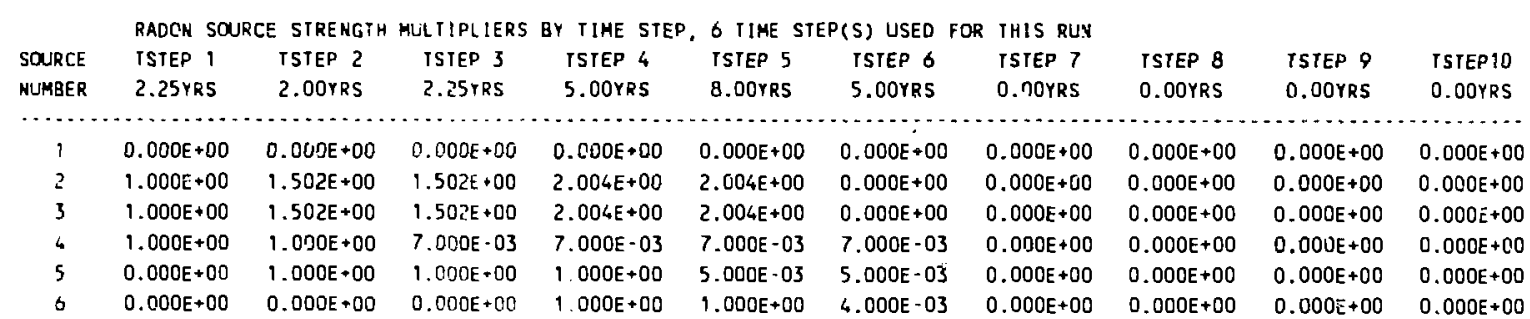




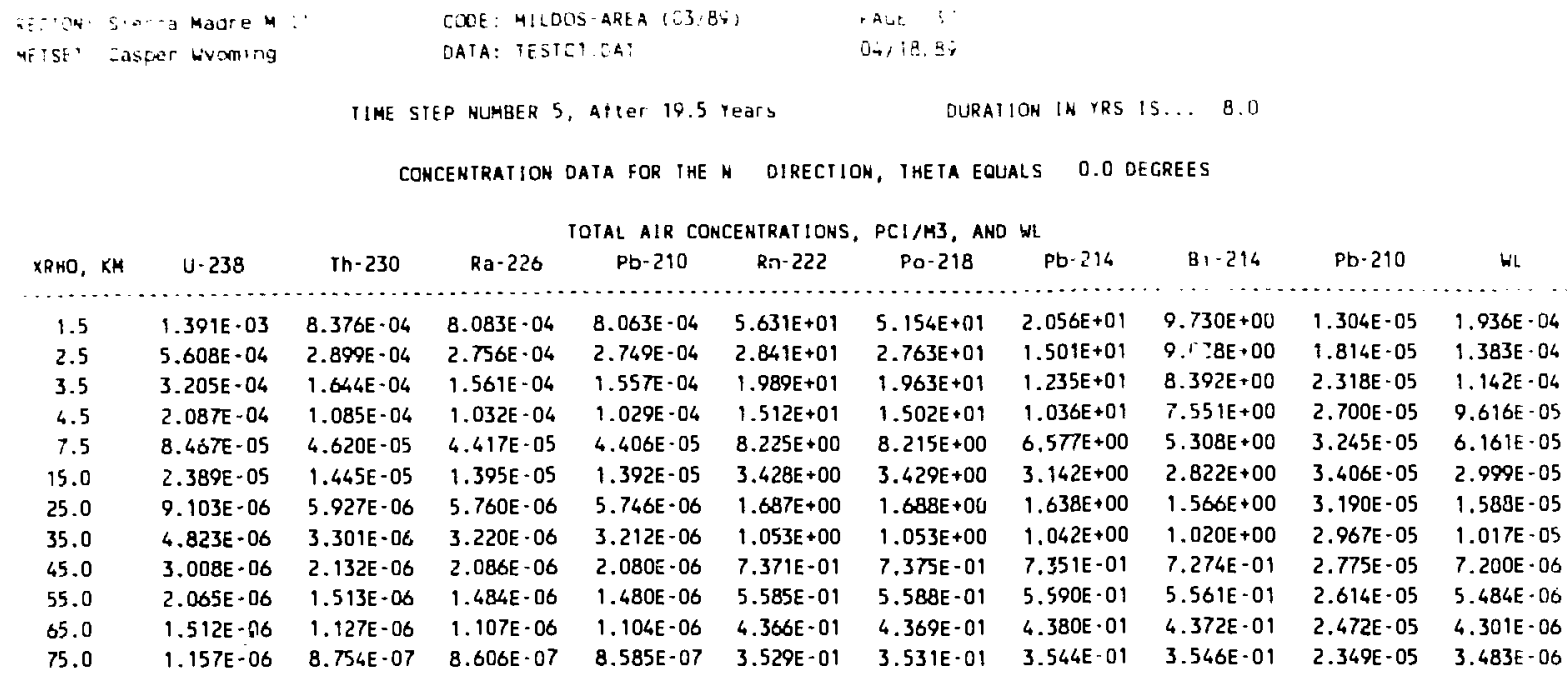

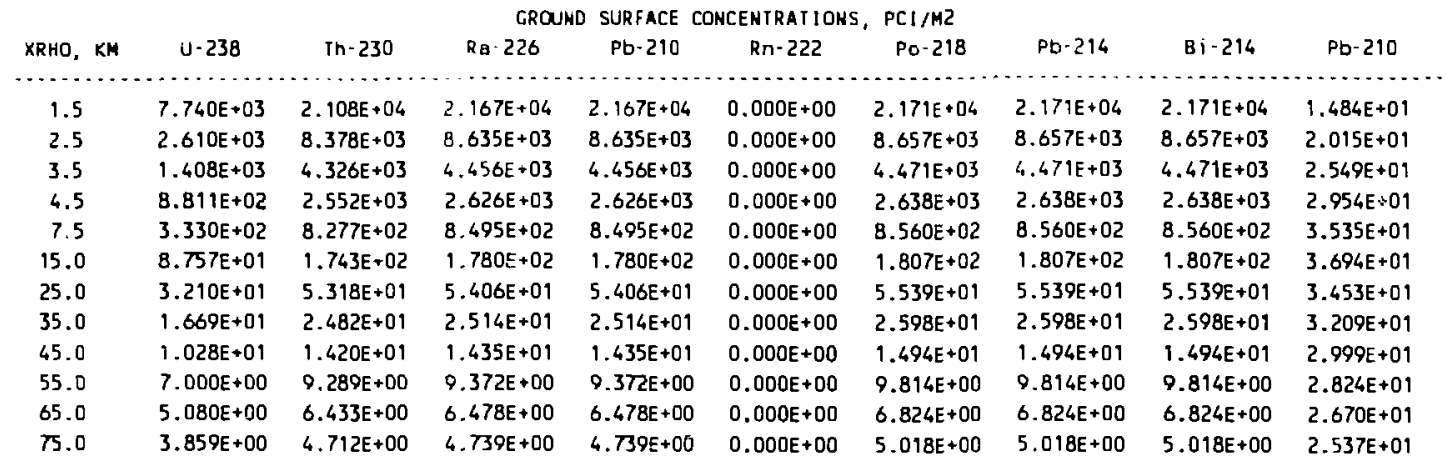

$\begin{array}{ccccc}\text { TOTAL DEPOSIIION RATES, PCI/M2 -SEC } \\ \times \ldots \text { ThO KH } & \text { U-238 } & \text { Th-230 } & \text { Ra-226 } & \text { Pb-210 } \\ 1.5 & 2.398 E-05 & 2.037 E-05 & 2.017 E-05 & 2.016 E-05 \\ 2.5 & 7.874 E-06 & 6.414 E-06 & 6.334 E-06 & 6.374 E-06 \\ 3.5 & 4.283 E-06 & 3.669 E-06 & 3.635 E-06 & 3.696 E-06 \\ 4.5 & 2.707 E-06 & 2.439 E-06 & 2.424 E-06 & 2.499 E-06 \\ 7.5 & 1.046 E-06 & 1.032 E-06 & 1.031 E-06 & 1.126 E-06 \\ 15.0 & 2.826 E-07 & 3.052 E-07 & 3.063 E-07 & 4.078 E-07 \\ 25.0 & 1.052 E-07 & 1.143 E-07 & 1.148 E-07 & 2.102 E-07 \\ 35.0 & 5.508 E-08 & 5.937 E-00 & 5.959 E-08 & 1.485 E-07 \\ 45.0 & 3.408 E-08 & 3.626 E-08 & 3.638 E-08 & 1.195 E-07 \\ 55.0 & 2.325 E-08 & 2.471 E-08 & 2.479 E-08 & 1.031 E-07 \\ 65.0 & 1.690 E-08 & 1.766 E-08 & 1.770 E-08 & 9.184 E-08 \\ 75.0 & 1.286 E-08 & 1.324 E-08 & 1.3766 E-08 & 8.372 E-08\end{array}$


REGLON: SIerra Madre Mill HEISCT: Casper Hyoming
COOE: MILDOS-AREA $(03 / 89)$ DATA: IESTC1.DAT
PAGE $\& 1$

$04 / 18 / 89$

TIME SIEP HUHBER S, After 19.5 Years

DURATION IN YRS $15 \ldots 8.0$

DOSES RECEIVED BY PEOPLE HITHIM 80 KILOAETERS

\begin{tabular}{|c|c|c|c|c|c|c|}
\hline PATHUAY & EFFECIIV & BONE & AVG.LUKG & LIVER & KIDNEY & BRONCHI \\
\hline- & & 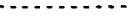 & & & & \\
\hline INHAL. & $7.371 E-01$ & $4.951 E+00$ & $2.609 E+00$ & $1.841 E+00$ & $9.131 \mathrm{E}-01$ & $9.361 E+01$ \\
\hline GROUND & $2.651 E-01$ & $2.651 \mathrm{E}-01$ & $2.651 \mathrm{E}-01$ & $2.651 \mathrm{IE}-01$ & $2.651 E-01$ & $2.651 E-01$ \\
\hline CLAUD & $7.822 E-01$ & $7.822 \mathrm{E}-01$ & $7.822 E-01$ & $7.822 E-01$ & $7.822 \mathrm{E}-01$ & $7.822 E-01$ \\
\hline VEG. ING & $5.379 E+90$ & o. $430 E+01$ & $5.379 E+00$ & $1.628 E+01$ & $1.35 S E+01$ & $5.379 E+00$ \\
\hline MEAT ING & $7.389 E-01$ & $9.065 E+00$ & $7.389 \mathrm{E}-01$ & $2.356 E+00$ & $1.927 \mathrm{E}+00$ & $7.389 E-01$ \\
\hline MILK ING & $2.102 E-01$ & $2.832 E+00$ & $2.102 E-01$ & 4. 187E-01 & $4.156 E-01$ & 2. $102 E-01$ \\
\hline RNPLUS50 & $0.000 E+00$ & $0.000 E+00$ & $0.000 E+00$ & $0.000 E+00$ & $0.000 E+00$ & $0.000 E+00$ \\
\hline IOTALS & 8. $112 E+00$ & $8.220 E+01$ & $9.984 E+00$ & $2.195 E+01$ & $1.786 E+01$ & $1.010 E+02$ \\
\hline
\end{tabular}

DOSES RECEIVED BY PEOPLE BEYOMD 80 KILOHETERS

\begin{tabular}{|c|c|c|c|c|c|c|}
\hline PAI HUAY & EFFECTIV & BONE & AVG. LUNG & LIVER & KIDNEY & BRONCHI \\
\hline INHAL. & $0.00 \cdot 30$ & $0.000 E+00$ & $0.000 E+00$ & $0.000 E+00$ & $0.000 E+00$ & $0.000 E+00$ \\
\hline GROUND & $0.000 E-00$ & 0. COOE +00 & $0.000 E+00$ & $0.000 E+00$ & $0.000 E+00$ & $0.000 E+00$ \\
\hline CLOUD & $0.000 E+00$ & $0.000 E+00$ & $0.000 \mathrm{E}+00$ & $0.000 E+00$ & $0.000 E+00$ & $0.000 E+00$ \\
\hline VEG. ING & $0.000 E+00$ & $0.000 E+00$ & $0.000 E+00$ & $0.000 E+00$ & $0.000 E+00$ & $0.000 E+00$ \\
\hline MEAT IHG & 2. $185 E+00$ & $2.681 E+01$ & $2.185 E+00$ & $6.965 E+00$ & $5.699 E+00$ & 2. $185 E+00$ \\
\hline HILK IHG & $0.000 E+00$ & $0.000 E+00$ & $0.000 E+00$ & $0.000 E+00$ & $0.000 E+00$ & $0.000 E+00$ \\
\hline RNPLUS50 & $1.736 E+02$ & $2.361 E+03$ & $3.947 \mathrm{E}+01$ & $1.736 \mathrm{E}+02$ & $1.736 \mathrm{E}+02$ & $1.136 E+03$ \\
\hline$\ldots \ldots$ & $\cdots$ & - & $\ldots$ & $-\cdots$ & & $=$ \\
\hline TOTALS & $1.758 E+02$ & $2.388 E+03$ & $4.165 E+01$ & $1.806 E+02$ & $1.793 \mathrm{E}+02$ & $1.138 E+03$ \\
\hline
\end{tabular}

TOTAL DOSES COMPUTED OVER ALL POPULATIONS

\begin{tabular}{|c|c|c|c|c|c|c|}
\hline FATHWAY & EFFECIIV & BONE & AVG.LUNG & LIVER & KIDNEY & BRONCHI \\
\hline \multicolumn{7}{|c|}{${ }_{1}$} \\
\hline INHAL. & $7.371 E \cdot 01$ & $4.951 E+00$ & $2.609 E+00$ & $1.841 \mathrm{E}+00$ & $9.131 E-01$ & $9.361 \mathrm{E}+01$ \\
\hline GROUND & $2.651 E-01$ & $2.651 \mathrm{E}-01$ & $2.651 E-01$ & $2.651 \mathrm{E}-01$ & $2.651 \mathrm{E}-01$ & $2.651 E-01$ \\
\hline CLOUD & $7.822 E-01$ & $7.822 E-01$ & $7.822 E-01$ & $7.822 \mathrm{E}-01$ & $7.822 \mathrm{E}-01$ & $7.822 E-01$ \\
\hline VEG. IHG & $5.379 \mathrm{E}+00$ & $6.430 E+01$ & $5.379 \varepsilon+00$ & $1.628 E+01$ & $1.355 E+01$ & $5.379 E+00$ \\
\hline MEAT ING & $2.924 E+00$ & $3.587 E+01$ & $2.924 E+00$ & $9.321 E+00$ & $7.626 \mathrm{E}+00$ & $2.924 E+00$ \\
\hline MILK ING & $2.102 E-01$ & $2.832 \mathrm{E}+00$ & $2.102 E-01$ & $4.187 E-01$ & $4.156 E-01$ & $2.102 E-01$ \\
\hline RNPLUS50 & $1.736 E+02$ & $2.361 E+03$ & $3.947 E+01$ & $1.736 E+02$ & $1.736 E+02$ & $1.136 E+03$ \\
\hline \multicolumn{7}{|c|}{ 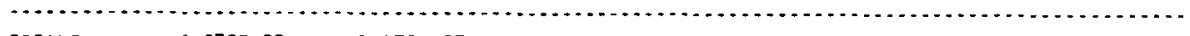 } \\
\hline TOTALS & $1.839 E+02$ & $2.470 E+03$ & $5.163 E+01$ & $2.025 E+02$ & $1.972 E+02$ & $1.239 E+03$ \\
\hline
\end{tabular}


REgION: Sierra Madre Mill METSET: CBSper Wyoming
COOE: MILDOS-AREA $(03 / 89)$

DATA: TE5TC1.DAT

TIME STEP MUMBER 5, After 19.5 Years
PAŨE 42

$04 / 18 / 89$

DURATIOH IN YRS IS... B.0

\begin{tabular}{|c|c|c|c|c|c|c|}
\hline \multirow[b]{2}{*}{ MO. } & \multirow[b]{2}{*}{ NAME } & \multirow[b]{2}{*}{ PTSZ } & \multicolumn{4}{|c|}{$\begin{array}{l}\text { INDIVIDUAL RECEPTOR PARTICULA } \\
\text { AIRBORNE CONCENTRATIONS, PCI/H3 }\end{array}$} \\
\hline & & & $U-238$ & $\mathrm{Th} \cdot 230$ & $\mathrm{Ra} \cdot 226$ & $\mathrm{~Pb}-210$ \\
\hline 1 & Fence Boundary $E$ & 1 & $1.114 E-03$ & $1.114 E-03$ & $1.114 E-03$ & $1.111 E-03$ \\
\hline 1 & Fence Boundary E & 2 & $2.896 \varepsilon-03$ & $1.508 E-04$ & $6.033 E-06$ & $6.019 E-06$ \\
\hline 1 & Fence Goundary E & 3 & $1.022 E-03$ & $1.200 E-02$ & $1.258 E-02$ & $1.255 E-02$ \\
\hline 1 & Fence Boundary E & 4 & $0.659 E-04$ & $1.291 \mathrm{E}-02$ & $1.356 \mathrm{E}-02$ & $1.352 E-02$ \\
\hline & COHCENTRATIOM TOTALS & & $5.698 \mathrm{E}-03$ & $2.618 E-02$ & $2.726 E-02$ & $2.719 \varepsilon-02$ \\
\hline$\cdots$ & (n. & $\cdots$ & 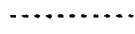 & 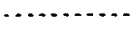 & & $\ldots \ldots$ \\
\hline 2 & Fence Boundary SSE & 1 & $3.723 E-04$ & $3.723 E-04$ & $3.723 E-04$ & $3.714 E-04$ \\
\hline 2 & Fence Boundary SSE & 2 & $9.059 E-04$ & $4.718 E-05$ & $1.887 \mathrm{E}-06$ & $1.883 E-06$ \\
\hline 2 & Fence Boundary SSE & 3 & $4.705 E-04$ & $5.033 E-03$ & $5.2 ד 5 E-03$ & $5.262 E-03$ \\
\hline 2 & Fence Boundary SSE & 4 & $3.178 E-04$ & $5.877 E-03$ & $6.171 E-03$ & $6.156 E-03$ \\
\hline & CONCENTRATION TOTALS & & $2.066 \mathrm{E}-03$ & $1.133 E-02$ & $1.182 E=02$ & $1.179 E-02$ \\
\hline & 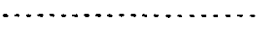 & & & & $\ldots$ & $\cdots$ \\
\hline 3 & Grazing $E$ & 1 & $6.901 E-04$ & $6.901 E-04$ & $6.901 E-34$ & $6.884 E-04$ \\
\hline 3 & Grazing $E$ & 2 & $1.700 E-03$ & $8.852 E-05$ & $3.541 E-06$ & $3.532 E-06$ \\
\hline 3 & Grazing E & 3 & $5.350 E-04$ & $4.601 E-03$ & $4.816 E-03$ & $4.805 E \cdot 03$ \\
\hline 3 & Grazing E & 4 & $2.854 E-04$ & 4.129E-03 & $4.332 E-03$ & $4.321 E-03$ \\
\hline & CONCEHTRATIOH TOTALS & & $3.210 E-03$ & $9.509 E-03$ & $9.842 \mathrm{E} \cdot 03$ & $9.818 \mathrm{E}-03$ \\
\hline & $\ldots \ldots$ & & & & & $\cdots$ \\
\hline & Grazing ESE & 1 & $3.150 E-04$ & $3.150 E-04$ & $3.150 E-04$ & $3.142 \mathrm{E}-04$ \\
\hline 4 & Grazing ESE & 2 & $7.244 \mathrm{E}-04$ & $3.773 E-05$ & $1.509 E-06$ & $1.505 E-06$ \\
\hline is & Grazing ESE & 3 & $2.040 \mathrm{E}-04$ & $2.433 E-03$ & $2.547 E-03$ & $2.541 \mathrm{E}-03$ \\
\hline 4 & Grazing ESE & 4 & $1.525 E \cdot 04$ & $2.251 E-03$ & $2.362 \mathrm{~F}-03$ & $2.356 E-03$ \\
\hline & CONCENTRATIOH TOTALS & & $1.456 \mathrm{E}-03$ & $5.036 E-03$ & $5.226 E-03$ & $5.213 E-03$ \\
\hline$\cdots$ & (n) & $\ldots$ & . . . . & 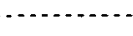 & 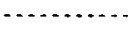 & $\cdots+\cdots$ \\
\hline 5 & Mearest Resident (HH & 1 & $2.143 E-04$ & $2.143 E-04$ & $2.143 E \cdot 04$ & $2.138 \mathrm{E}-04$ \\
\hline 5 & Mearest Resident (NH & 2 & $4.986 E-04$ & $2.597 \mathrm{E}-05$ & $1.039 E-06$ & $1.036 E-06$ \\
\hline 5 & Hearest Resident SWH & 3 & $1.555 E-04$ & $1.682 E-04$ & $1.688 \mathrm{E}-04$ & $1.684 \mathrm{E}-04$ \\
\hline 5 & Mearest Resident (NN & 4 & $3.186 \mathrm{E}-05$ & $5.036 E-05$ & $5.126 E-05$ & $5.116 E-05$ \\
\hline & COMCENTRATION TOTALS & & $9.002 E-04$ & 4. $5888 E-04$ & $4.355 E-04$ & $4.344 E-04$ \\
\hline$\cdots$ & (n) & $\cdots$ & $\ldots \ldots \ldots$ & $\ldots$ & (............... & …...... \\
\hline 6 & Hearest Res in Pre. & $i$ & $6.748 E-04$ & $6.748 E-04$ & $6.747 \mathrm{E}-04$ & $6.731 E-04$ \\
\hline 6 & Nearest Res in Pre. & 2 & $1.193 \mathrm{E}-03$ & $6.215 E-05$ & $2.486 \mathrm{E}-06$ & $2.480 E-06$ \\
\hline 6 & Nearest Res in Pre. & 3 & $4.465 E-04$ & $1.396 E-03$ & $1.446 \mathrm{E}-03$ & $1.442 E-03$ \\
\hline 6 & Mearest Res in Pre. & 4 & $2.152 E-04$ & $1.019 E-03$ & $1.061 E-03$ & $1.058 E-03$ \\
\hline & CONCENTRATIOH TOIALS & & $2.530 E-03$ & $3.151 E-03$ & $3.184 \mathrm{E}-03$ & $3.176 E-03$ \\
\hline
\end{tabular}

\begin{tabular}{|c|c|c|c|}
\hline \multicolumn{4}{|c|}{ GROUHO CONCENTRATIONS, PCI/MZ } \\
\hline$u-238$ & Th-230 & Ra-226 & $\mathrm{Pb}-210$ \\
\hline & & & \\
\hline 3.S19E+03 & S.S19E+ (1.5 & $3.507 \mathrm{E}+03$ & $3.307 E+03$ \\
\hline $8.631 E+03$ & $4.495 E+02$ & $1.792 \mathrm{E}+01$ & $1.792 \mathrm{E}+01$ \\
\hline $2.757 \mathrm{E}+03$ & $2.891 E+04$ & $3.021 E+04$ & $3.021 E+04$ \\
\hline $1.434 E+0^{\prime}$ & $2.657 \mathrm{E}+05$ & $2.782 E+05$ & $2.782 E+05$ \\
\hline $2.905 E+04$ & $2.984 E+05$ & $3.118 E+05$ & $3.118 E+05$ \\
\hline 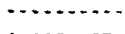 & & 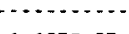 & - \\
\hline $1.109 E+03$ & $1.109 E+03$ & $1.105 E+03$ & $1.105 E+03$ \\
\hline $2.700 E+03$ & $1.406 E+02$ & $5.604 E+00$ & $5.604 E+00$ \\
\hline $1.282 E-03$ & $1.215 E+04$ & $1.269 E+04$ & $1.269 E+04$ \\
\hline $6.903 E+03$ & $1.209 E+05$ & $1.265 E+05$ & $1.265 E+05$ \\
\hline $1.199 E+04$ & $1.343 E+05$ & $1.403 E+05$ & $1.403 E+05$ \\
\hline$\cdots$ & - & - & $\ldots \ldots$ \\
\hline $2.056 E+03$ & $2.056 E+03$ & $2.049 \mathrm{E}+03$ & $2.049 E+03$ \\
\hline $5.065 E+03$ & $2.638 \mathrm{E}+02$ & $1.051 E+01$ & $1.051 E+01$ \\
\hline $1.496 E+03$ & $1.137 E+04$ & $1.186 E+04$ & $1.186 E+04$ \\
\hline $6.530 E+03$ & $8.680 E+04$ & $9.079 E+04$ & $9.079 E+04$ \\
\hline $1.515 E+04$ & $1.005 E+05$ & $1.047 E+05$ & $1.047 E+05$ \\
\hline$\cdots$ & & & \\
\hline$c .385 \mathrm{E}+02$ & $9.384 E+02$ & $9.351 \mathrm{E}+02$ & $9.351 \mathrm{E}+02$ \\
\hline $2.159 E+03$ & $1.124 E+02$ & $4.481 E+00$ & $4.481 E+00$ \\
\hline $7.359 E+02$ & $0.039 E+03$ & $6.301 E+03$ & $6.301 E+03$ \\
\hline $3.491 E+03$ & $4.755 E+04$ & $4.974 E+04$ & $4.974 E+04$ \\
\hline $7.325 E+03$ & $5.464 E+04$ & $5.698 E+04$ & $5.698 E+04$ \\
\hline$\cdots \cdots$ & & 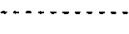 & $\cdots$ \\
\hline $6.386 E+02$ & $6.386 E+02$ & $6.363 E+02$ & $6.363 E+02$ \\
\hline $1.486 E+03$ & $7.738 E+01$ & $3.084 E+0 C$ & $3.084 E+00$ \\
\hline $5.277 \mathrm{E}+02$ & $2.034 E+03$ & $2.102 E+03$ & $2.102 \mathrm{E}+03$ \\
\hline $1.316 E+03$ & $1.310 E+04$ & $1.364 E+04$ & $1.364 E+04$ \\
\hline $3.969 E+03$ & $1.585 E+04$ & $1.638 \mathrm{BE}+04$ & $1.638 E+04$ \\
\hline ........ & & $-\ldots$ & $\ldots \ldots$ \\
\hline $2.011 \mathrm{E}+03$ & $2.010 E+03$ & $2.003 E+03$ & $2.003 E+03$ \\
\hline $3.556 E+03$ & 1. $852 E+02$ & $7.382 E+00$ & $7.382 \mathrm{E}+00$ \\
\hline $1.371 E+03$ & $5.127 E+03$ & $5.303 E+03$ & $5.303 E+03$ \\
\hline $5.845 E+03$ & $3.341 E+04$ & $3.471 E+04$ & $3.471 E+04$ \\
\hline $1.278 E+04$ & $4.073 E+04$ & $4.203 E+04$ & $4.203 E * 04$ \\
\hline
\end{tabular}


REGION: Sierra Madre Mill METSET: Casper Hyoming
COOE: MILDOS-AREA (03/89)

DATA: TESTC1.DAT

TIME SIEP NUMBER 5, After 19.5 rears
PAGE 43

$04 / 18 / 89$

DURATION IN YRS IS... 8.0

INDIVIDUAL RECEPTOR RADON AHD RADON DAUGHTER CONCENTRATIONS AIRBORNE CONCENTRATIONS, PCI/M3

GROUND CONCENTRATIONS, PCI/M2

NO. Rn-222 Fo-218 Pb-214 Bi-214 Pb-210 Bi-210

Po-210

UL PO-218 Pb-214

Bi-214 Pb-210

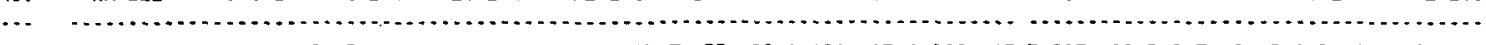

$1 \quad 1.144 E+03 \quad 6.346 E+02 \quad 9.636 E+012.318 E+01 \quad 1.140 E-05 \quad 7.655 E-091.606 E-13 \quad 1.229 E-03 \quad 5.027 E+025.027 E+025.027 E+02 \quad 1.931 E+01$

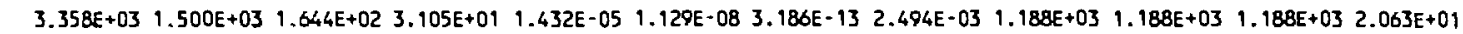
4.980E+02 3.780E+02 8.780E+01 3.237E+01 3.010E-05 3.620E-08 1.302E-12 9.552E-04 2.994E+02 2.994E+02 2.994E+02 3.911E+01

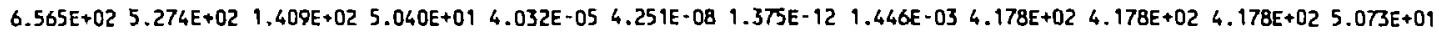

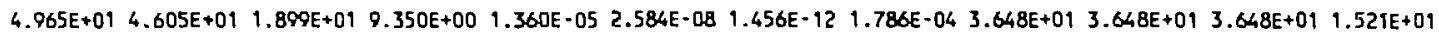
$1.057 E+02 \quad 9.073 E+012.888 E+01 \quad 1.445 E+012.564 E-05 \quad 5.683 E-083.641 E-12 \quad 2.938 E-047.186 E+017.186 E+017.186 E+012.938 E+01$ 
REGION: Sierra Madre Mill METSET: Casper Hyoming
CODE : MILDOS-AREA (03/89)

DATA: TESTC1.DAT

IIME SIEP MLMBER 5 , After 19.5 Yeats
PAGE 44

$04 / 18 / 89$

DURATION IH YRS IS... 8.0

NUABER I MAME $=$ Fence Boundary $E \quad X=1.6 \mathrm{KM}, Y=-0.2 \mathrm{KM}, Z=8.8 \mathrm{M}, \mathrm{DIST}=1.6 \mathrm{KM}, 1 \mathrm{RIYPE}=0$

RESULTS OF MPC CHECK AI THIS LOCATIOH

\begin{tabular}{|c|c|c|c|c|c|c|c|c|}
\hline & $v-238$ & $U-236$ & Th. 230 & $R a-226$ & $R n-222(W L)$ & PD. 210 & $\mathrm{Bi}-210$ & Po-210 \\
\hline CONC.. PCI/H3 & $5.70 E-03$ & $5.70 E-03$ & $2.62 E-02$ & $2.73 E-02$ & $1.23 E-03$ & $2.72 \mathrm{E}-02$ & $2.72 E-02$ & $2.72 \mathrm{E}-02$ \\
\hline MPC, PCl/HB & $5.00 E+00$ & $4.00 E+00$ & $8.00 E-02$ & $2.00 E+00$ & $3.33 E-02$ & $4.00 E+00$ & $2.00 E+02$ & $7.00 E+00$ \\
\hline FRACTION OF MPC & $1.14 E=03$ & $1.42 \mathrm{E} \cdot 03$ & $3.27 E-01$ & $1.36 E-02$ & $3.69 E-02$ & $6.80 E-03$ & $1.36 E-04$ & $3.88 E-03$ \\
\hline
\end{tabular}

SUM OF FRACTIONS EOUALS 3.91E-01

NIMBER 2 HAME $=$ Fence Boundary SSE $X=1.1 \mathrm{KH}, Y=-1.6 \mathrm{KM}, Z=2.4 \mathrm{H}, 015 T=1.9 \mathrm{KM}, 1 \mathrm{RTYPE}=0$

RESULTS OF MPC CHECK AT THIS LOCATION

\begin{tabular}{|c|c|c|c|c|c|c|c|c|}
\hline & $u-238$ & $u-234$ & Th-250 & $R a-226$ & $R n-222($ LL) & $P b-210$ & $8 i-210$ & Po-210 \\
\hline CONC., PCI/M3 & $2.07 E-03$ & $2.07 E-03$ & $1.13 E-02$ & $1.18 \mathrm{E}-02$ & $2.49 E \cdot 03$ & $1.18 E-02$ & $1.18 \mathrm{E}-02$ & $1.18 \mathrm{E}-02$ \\
\hline $\mathrm{MPC}, \mathrm{PCI} / \mathrm{H} 3$ & $5.00 E+00$ & $4.00 E+00$ & 8.00E-0? & $2.00 E+00$ & $3.33 E-02$ & $4.00 E+00$ & $2.00 E+02$ & $7.00 E+00$ \\
\hline FRACIION OF MPC & $4.13 E \cdot 04$ & $5.17 E-04$ & $1.42 E-01$ & $5.91 E-03$ & $7.49 E-02$ & $2.95 E-03$ & $5.90 E-05$ & $1.68 E-03$ \\
\hline
\end{tabular}

SUH OF FRACTIONS EOUALS 2.28E-01 
REgLON: Sierra Madre Mill HETSET: Casper Hyoming
COOE: MILDOS-AREA (03/89)

DATA: TESTCI.DAT

TIME STEP MUMBER 5, After 19.5 Years
PAGE 45

$04 / 18 / 89$

DURATION IN YRS IS... 8.0

HUMBER 3 NAME $=$ Grazing E $X=2.6 \mathrm{KM}, Y=0.0 \mathrm{KM}, Z=3.7 \mathrm{M}, \mathrm{DISI}=2.6 \mathrm{KM}$, IRTYPE $=10$

LOCFR190 AMHUAL DOSE COMIITENTS COMPUTED FOR THIS LOCATIOH, MREM/YR

\begin{tabular}{|c|c|c|c|c|c|c|c|}
\hline AGE & PATHUAY & EFFECTIV & BONE & AVG. LUNG & LIVER & KIDKEY & BRONCH I \\
\hline \multicolumn{8}{|c|}{ 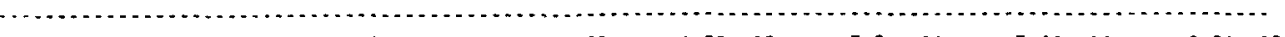 } \\
\hline INFANT & INHAL. & $3.91 E+01$ & $1.14 E+02$ & $1.88 E+02$ & $3.96 E+01$ & $3.10 E+01$ & $0.00 E+00$ \\
\hline IKFANT & GROUND & $3.75 E-01$ & $3.75 E-01$ & $3.75 E-0 ?$ & $3.75 E-01$ & $3.75 E-01$ & $3.75 E-01$ \\
\hline INFANT & cLoo & 8. $68 \mathrm{BE}-07$ & $8.68 E-07$ & B. $68 E-07$ & $8.68 E-07$ & 8. $68 E-07$ & 8.68E- 07 \\
\hline INFANT & VEG. IHG & $0.00 E+00$ & $0.00 E+00$ & $0.00 E+00$ & $0.00 E+00$ & $0.00 E+00$ & $0.00 E+00$ \\
\hline INFANT & MEAT ING & $0.00 E+00$ & $0.00 E+00$ & $0.00 E+00$ & $0.00 E+00$ & $0.00 E+00$ & $0.00 E+00$ \\
\hline INFANT & MILK ING & $0.00 E+00$ & $D .00 E+00$ & $0.00 E+00$ & $0.00 E+00$ & $0.00 E+00$ & $0.00 E+00$ \\
\hline \multicolumn{8}{|c|}{ 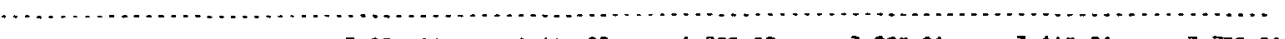 } \\
\hline INFANT & TOTALS & $3.95 E+01$ & $1.14 E+02$ & $1.88 E+02$ & $3.99 E+01$ & $3.14 E+01$ & $3.75 E-01$ \\
\hline AGE & PATHWAY & EFFECT IV & BONE & AVG.LUNG & LIVER & KIDNEY & BRONCHI \\
\hline \multicolumn{8}{|c|}{ (1, } \\
\hline CHILO & INHAL . & $1.72 \mathrm{E}+01$ & B. $17 E+01$ & $8.76 E+01$ & $1.51 E+01$ & $1.01 E+01$ & $0.00 E+00$ \\
\hline CHILD & GROUND & $3.75 E-01$ & $3.75 E-01$ & $3.75 E-01$ & $3.75 E-01$ & $3.75 \mathrm{E}-01$ & $3.75 E-01$ \\
\hline CHILD & CLOUD & $8.68 \mathrm{E}-07$ & $8.68 E-07$ & $8.68 E-07$ & 8. $68 \mathrm{BE}-07$ & $8.68 E-07$ & 8.68E -07 \\
\hline CHILD & VEG. ING & $1.69 E+01$ & $8.56 E+01$ & $7.42 E+01$ & $7.42 E+01$ & $5.54 E+01$ & $0.00 E+00$ \\
\hline CHILD & MEAT ING & $2.52 E+00$ & $1.27 E+01$ & $1.20 E+01$ & $1.20 E+01$ & $8.89 E+00$ & $0.00 \mathrm{E}+00$ \\
\hline CHILD & MILK ING & $0.00 \mathrm{E}+00$ & $0.00 E+00$ & $0.00 \mathrm{E}+00$ & $0.00 E+00$ & $0.00 E+00$ & $0.00 E+00$ \\
\hline \multicolumn{8}{|l|}{ chon } \\
\hline CHILD & TOTALS & $3.70 E+01$ & $1.80 E+02$ & $1.74 E+02$ & $1.02 E+02$ & $7.41,001$ & $3.75 E-01$ \\
\hline AGE & PAIHUAY & EFFECIIV & BONE & AVG.LLNG & LIVER & M IDNEY & BRONCHI \\
\hline \multicolumn{8}{|c|}{$n_{0}$} \\
\hline TEEMAGE & IHHAL. & $1.07 E-01$ & $9.69 E+01$ & $4.53 E+01$ & $6.82 E+00$ & $5.24 E+00$ & $0.00 E+00$ \\
\hline TEENAGE & GROUND & $3.75 E-01$ & $3.75 E-01$ & $3.75 E-01$ & $3.75 E-01$ & $3.75 E-01$ & $3.75 E-01$ \\
\hline TEENAGE & CLOUD & $8.68 E-07$ & $8.68 E-07$ & $8.68 E-07$ & $8.68 E-07$ & $8.68 \mathrm{~B}-07$ & $8.68 E-07$ \\
\hline TEENAGE & VEG. IMG & $2.78 \mathrm{E}+01$ & $4.56 E+02$ & $6.61 E+01$ & $0.61 E+01$ & $5.64 E+01$ & $0.00 E+00$ \\
\hline TEENAGE & MEAT ING & $4.00 E+00$ & $6.55 E+01$ & $1.05 E+01$ & $1.05 E+01$ & $8.85 E+00$ & $0.00 E+00$ \\
\hline TEENAGE & MILK ING & $0.00 E+00$ & $0.00 E+00$ & $0.00 E+00$ & $0.00 \mathrm{E}+0 \mathrm{U}$ & $0.00 E+00$ & $0.00 E+00$ \\
\hline \multicolumn{8}{|c|}{ - } \\
\hline TEENAGE & TOTALS & $4.29 E+01$ & $6.19 E+02$ & $1.22 E+02$ & $8.38 E+01$ & $7.08 E+01$ & $3.75 E-01$ \\
\hline AGE & PATHUAY & EFFECTIV & BONE & AVG.LUNG & LIVER & KIDNEY & BRONCHI \\
\hline \multicolumn{8}{|c|}{ 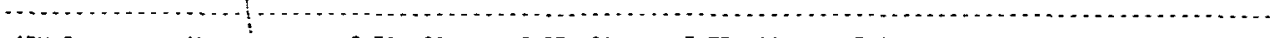 } \\
\hline ADUL I & INHAL: & $9.30 E+00$ & $8.53 E+01$ & $3.75 E+01$ & $3.22 E+00$ & $3.72 E+00$ & $0.00 \subseteq+00$ \\
\hline ADUL I & GROUND & $3.75 E-01$ & $3.75 E-01$ & $3.75 E-01$ & 3. $75 E-01$ & $3.75 E-01$ & $3.75 E-01$ \\
\hline ADUL T & CLOSD & $8.68 E-07$ & $8.68 E-07$ & $8.68 E-07$ & $8.68 E-07$ & $8.68 E-07$ & $8.68 E-07$ \\
\hline ADULT & VEG. ING & $1.58 E+01$ & $1.93 E+02$ & $4.31 E+01$ & $4.31 E+01$ & $3.59 E+01$ & $0.00 E+00$ \\
\hline ADUL T & HEAT ING & $2.92 \mathrm{E}+00$ & $3.60 E+01$ & $8.69 \mathrm{E}+00$ & $8.69 E+00$ & $7.15 E+00$ & $0.00 E+00$ \\
\hline ADUL T & MILK IHG & $0.00 E+00$ & $0.00 E+00$ & $0.00 E+00$ & $0.00 E+00$ & $0.00 E+00$ & $0.00 E+00$ \\
\hline ADUL $T$ & TOTALS & $2.84 E+01$ & $3.15 E+02$ & $8.96 E+01$ & $5.74 E+01$ & $4.71 E+01$ & $3.75 E-01$ \\
\hline
\end{tabular}


REGION: Sierra Madre Mill. MEISET: Casper Hyoning
CODE: MILDOS-AREA (03/89)

DATA: IESTC1.DAT

TIHE STEP MUMBER 5, After 19.5 Years
PAGE 46

$04 / 18 / 89$

NUMBER 3 NAME $=$ Grazing $E$

$X=2.6 \mathrm{KM}, \mathrm{Y}=0.0 \mathrm{KM}, Z=3.7 \mathrm{M}, 0 I S T=2.6 \mathrm{KM}, \operatorname{IRTYPE}=10$

TOTAL ANMUAL DOSE COMHITMENTS COMPUTED FOR IHIS LOCATIOH, MREM/YR

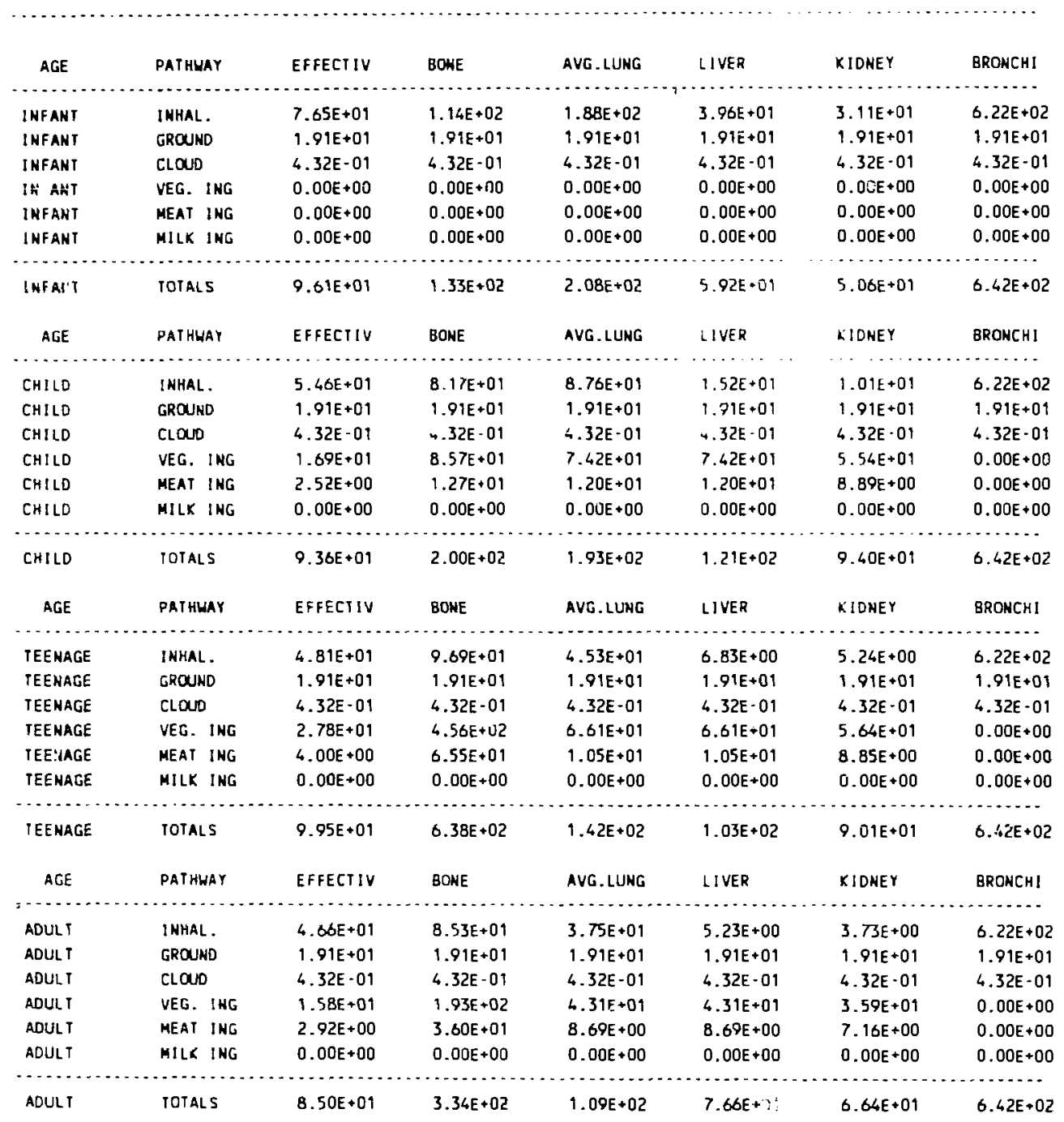




\section{C.6 LISTING OF TEST PROBLEM TESTC2.DAT}

\section{\&INDATA}

IFTODO $=4 * 0,2 \star 1,4 * 0$,

IRTYPE $=2 \star 0,4 \star 10$,

$\mathrm{JC}=1,0,1,2 \star 0,2 \star 1,0.1,0$,

FRADON $=0.86,0.06,0.04,0.04$,

IPACT $=3^{\star} 0,1,2,3,4^{\star} 0$,

NSORCE $=6$,

PACT $=11.4,17.1,22.8,271.0,407.0,542.5,284.4,427.1,570.0,284.4,427.1,570.0$, PAJUST $=$

$1.0,2 \star 1.5,2 \star 2.0,15^{\star} 0.0$,

$1.0,2 \star 1.502,2 \star 2.004,5 \star 0.0, \quad 1.0,2^{\star} 1.502,2 \star 2.004,5 \star 0.0$,

$1.0,2 \star 1.502,2 \star 2.004,5^{\star} 0.0,1.0,2 \star 1.502,2 \star 2.004,5 * 0.0$,

$0.3,1.0,8 * 0.0,2 \star 1.0,4 * .007,4 * 0.0$,

$0.0,2^{\star} 0.3,1.0,6^{\star} 0 ., \quad 0.0,3^{\star} 1.0,2^{\star} 0.005,4^{\star} 0.0$,

$3 \star 0.0,2 \star 0.3,5 \star 0.0, \quad 3 * 0.0,2 \star 1.0,0.004,4 \star 0.0$,

$80 * 0.0$,

SORCE $=$

$2 \star 0.0,20.0,0.0,4.1388 \mathrm{E}-2,2.1556 \mathrm{E}-3,2 \star 8.6225 \mathrm{E}-5,0.0,1101,1.0,17.0$,

$2 \star 0.40,6.0,0.16,4 * 4.084 E-2,1089.74,1201,3.0,0.0$,

$2 \star 0.20,2 \star 0.0,4 \star 2.602 \mathrm{E}-2,41.64,1301,2.0,0.0$,

$1.393,0.975,-10.0,0.143,4^{\star} 1.0,1281.5,5001,3.0,0.0$,

$-1.30,-.844,-10.0,0.270,4^{\star} 1.0,3636.80,5002,3.0,0.0$,

$1.092,-0.975,-10.0,0.827,4^{\star} 1.0,14863.23,5003,3.0,0.0$,

FAS $=3 *-1$.

SRNS $=284 ., 427 ., 570$,

$\mathrm{HDP}=50.0$,

FREQ $=$

$.000069, .000240, .000103, .000240, .000171, .000103, .000069, .000411$, $.000137, .000206, .000240, .000240, .000377, .000171, .000206, .000103$, $.000137, .000274, .000206, .000069, .000137, .000206, .000137, .000617$ $.000069, .000206, .000069, .000274, .000548, .000343, .000000, .000206$, $64 \star 0.0, .000554, .000507, .000374, .000421, .000960, .000424, .000665, .000651$, $.000977, .000410, .000613, .000445, .001126, .000402, .000208, .000644$, $.000959, .001233, .000685, .000411, .001233, .001165, .001302, .001165$, $.002124, .001028, .001576, .001370, .001370, .000959, .000548, .001096$, $.000685, .000617, .000685, .000411, .000617, .000206, .000548, .000274$, $.000548, .000685, .000822, .001096, .001781, .000685, .000754, .000822$, $48 \star 0.0, .000186, .000133, .000115, .000118, .000366, .000186, .000127, .000037$, $.000282, .000186, .000186, .000292, .000179, .000273, .000320, .000028$, $.000959, .001370, .000959, .001028, .001781, .000959, .001233, .000822$, $.001507, .000959, .00095 y, .001713, .002398, .001302, .000754, .000617$, $.002535, .001850, .001576, .001713, .002329, .001918, .001233, .000822$, $.001233, .001987, .003699, .006439, .004727, .002261, .001644, .001576$, $.000274, .000137, .000137, .000137, .000343, .000343, .000137, .000000$, $.000343, .000959, .002055, .001713, .001918, .000343, .000411, .000685$, $.0, .000069,6^{\star} 0.0, .000137, .006069,2^{\star} .000343, .000411, .000206,12^{\star} 0.0$, $.000069, .000137, .000069,3 * 0.0$

$.000792, .001053, .000854, .000741, .000598, .000592, .000548, .000268$, $.000548, .000336, .000411, .000530, .000679, .000816, .000430, .001009$, $.005412, .005823, .004453, .003220, .004110, .003220, .001918, .001302$, $.001918, .001233, .002055, .003357, .003357, .002398, .001439, .004521$, $.011440, .014249, .010207, .008768, .009248, .004932, .003014, .001370$, $.002124, .006302, .014180, .021304, .017468, .005412, .005206, .005001$, $.011097, .014865, .010275, .006508, .010001, .005480, .001987, .000548$, $.003699, .030826, .065420 \ldots 051993, .019318, .009453, .005891, .004042$, 


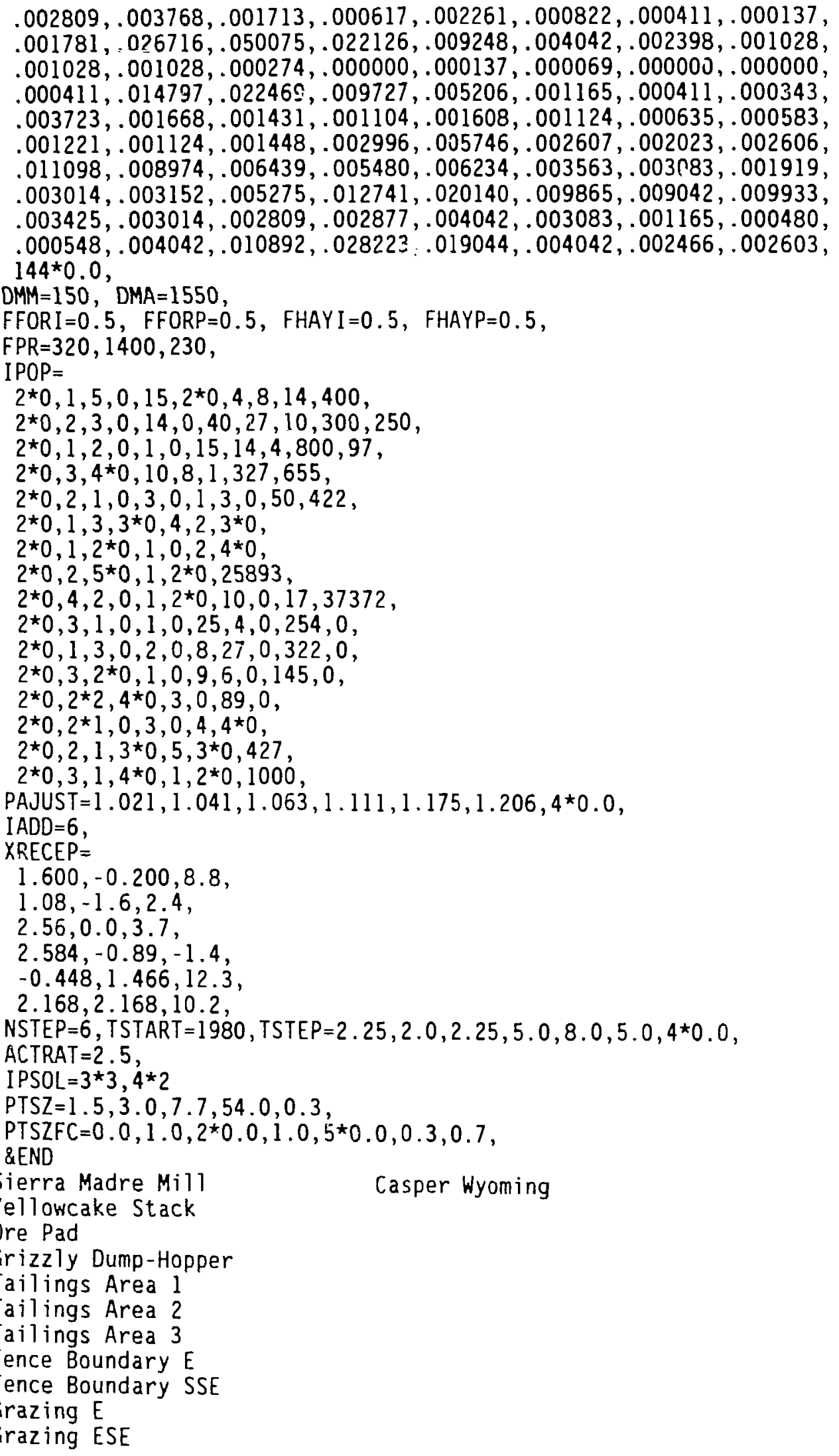




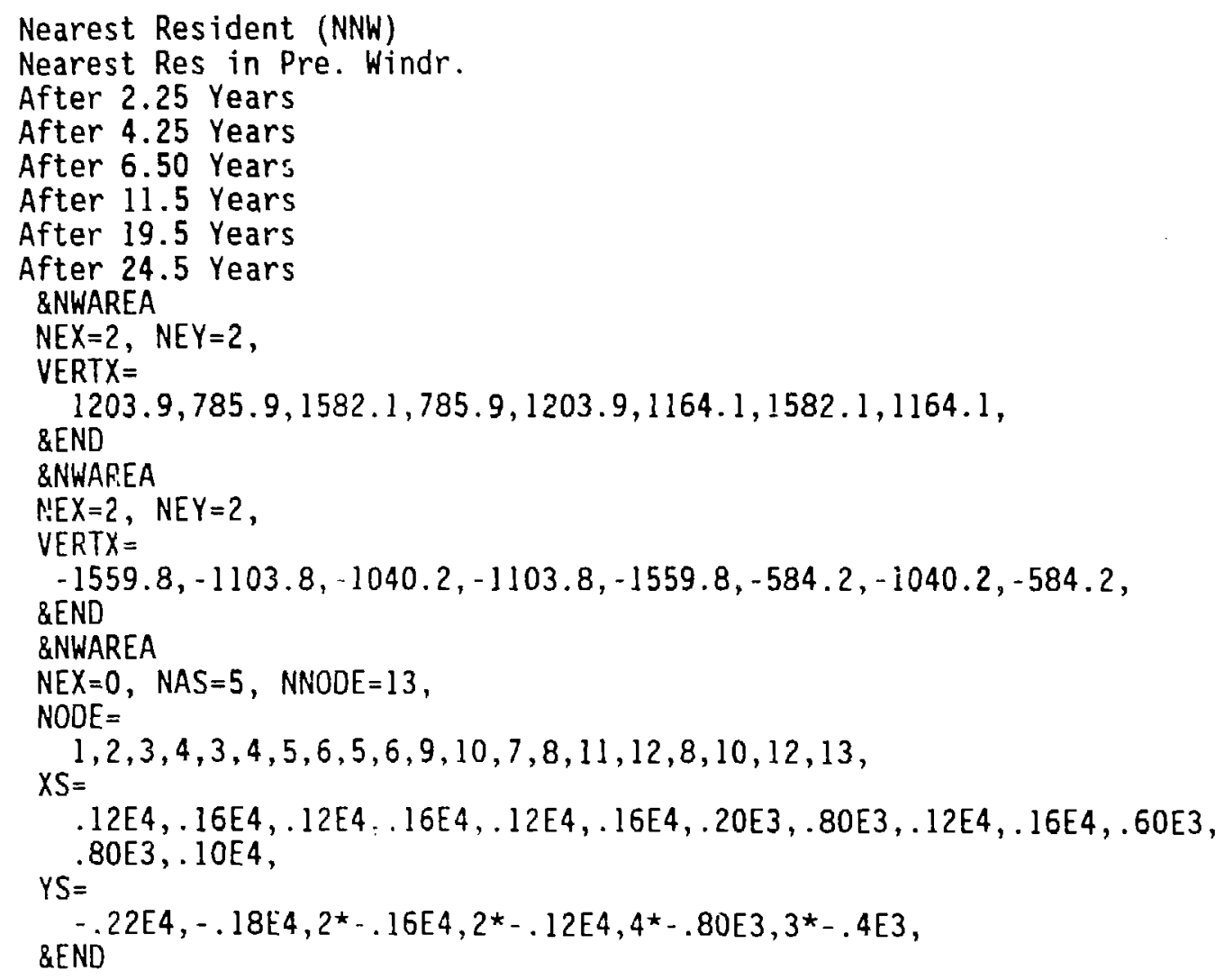




\section{C.7 SELECTED OUTPUT FROM TEST PROBLEM TESTC2.DAT}

REGION: Sierra Madre Mill

METSE $\mathrm{I}$ : Casper Hyoming

\author{
COOE: MILDOS-AREA (03/89) \\ PAGE 1 \\ DATA: TESTCZ.DAT \\ $04 / 18 / 89$
}

TABLE OF CONTENTS

IIME STEP 1, After 2.25 Years

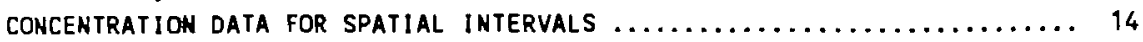

ANMUAL POPULATION DOSE COMMITMENTS, PERSON-REM PER YEAR

POPULATION DOSE SUMAARY

TIME STEP 2, After 4.25 Years

CONCENTRATION DATA FOR SPATIAL INTERVALS $\ldots \ldots \ldots \ldots \ldots \ldots \ldots \ldots \ldots \ldots \ldots$

AKNUAL POPULATION DOSE COMMITMENTS, PERSON-REH PER YEAR

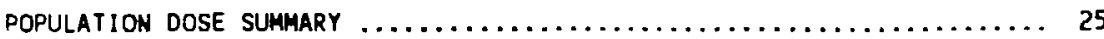

TIME STEP 3, After 6.50 Years

CONCENTRATION DATA FOR SPATIAL INTERVALS $\ldots \ldots \ldots \ldots \ldots \ldots \ldots \ldots \ldots \ldots \ldots$

ANNUAL POPULATION DOSE COMHITHENTS, PERSON-REM PER YEAR

POPULATION DOSE SUMMARY

TIME STEP 4, After 11.5 Years

CONCENTRATION DATA FOR SPATIAL INTERVALS $\ldots \ldots \ldots \ldots \ldots \ldots \ldots \ldots \ldots \ldots \ldots$

ANNUAL POPULATION DOSE COMMITMENTS, PERSON-REM PER YEAR

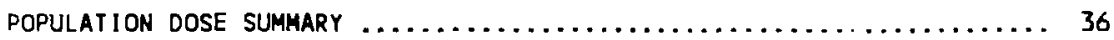

IIME STEP 5, After 19.5 Years

CONCENTRATION DATA FOR SPATIAL INTERVALS $\ldots \ldots \ldots \ldots \ldots \ldots \ldots \ldots \ldots \ldots \ldots$

ANNUAL POPULATION DOSE COMHITMENTS, PERSON-REM PER YEAR

POPULATION DOSE SUMMARY $\ldots \ldots \ldots \ldots \ldots \ldots \ldots \ldots \ldots \ldots \ldots \ldots \ldots \ldots \ldots \ldots . \ldots 1$

INDIVIDUAL RECEPTOR PARTICULATE CONCENTRATIONS $\ldots \ldots \ldots \ldots \ldots \ldots \ldots \ldots \ldots .42$

INDIVIDUAL RECEFTOR RADON AND RADON DAUGHTER CONCENTRATIONS ......... 43

INDIVIDUAL RECEPTOR MPC CHECK AND/OR ANHUAL DOSE COMMITHENTS ........ 44

TIME SIEP 6, AÝtET 24.5 Years

CONCENTRATION DATA FOR SPATIAL INTERVALS $\ldots \ldots \ldots \ldots \ldots \ldots \ldots \ldots \ldots \ldots . \ldots 3$

ANNUAL POPULATION DOSE COMMITMENTS, PERSON-REM PER YEAR

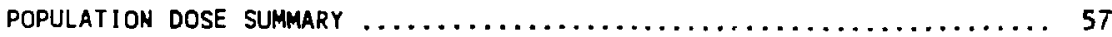

INDIVIDUAL RECEPTOR PARTICULATE CONCENTRATIONS $\ldots \ldots \ldots \ldots \ldots \ldots \ldots \ldots \ldots .58$

INDIVIOUAL RECEPTOR RADON AHD RADON DAUGHTER CONCENTRATIONS $\ldots \ldots \ldots \ldots .59$

INDIVIDUAL RECEPTOR MPC CHECK AND/OR ANRUAL DOSE COMHITMENTS $\ldots \ldots \ldots \ldots .60$ 
REgION: Sierra Madre Hill

METSET: Casper H.yoming

DATA: TESTCZ.DAT

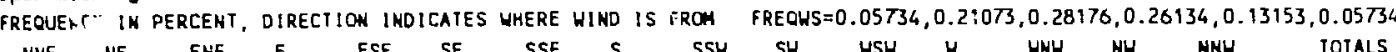

PAGE 2

$04 / 18 / 89$

\section{STABILITY CLAS',}

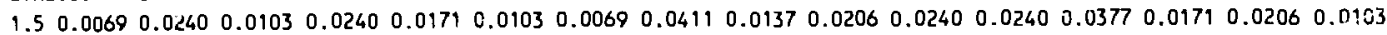

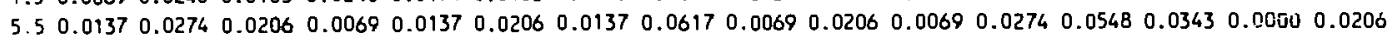
$\begin{array}{lllllllllllllllllll}10.0 & 0.0000 & 0.0000 & 0.0000 & 0.0000 & 0.0000 & 0.0000 & 0.0000 & 0.0000 & 0.0000 & 0.0000 & 0.0000 & 0.0000 & 0.0000 & 0.0000 & 0.0000 & 0.0000\end{array}$ $\begin{array}{llllllllllllllllll}15.5 & 0.0000 & 0.0000 & 0.0000 & 0.0000 & 0.0000 & 0.0000 & 0.0000 & 0.0000 & 0.0000 & 0.0000 & 0.0000 & 0.0000 & 0.00 u 0 & 0.0000 & 0.0000 & 0.0000\end{array}$ $\begin{array}{llllllllllllllllllll}21.5 & 0.0000 & 0.0000 & 0.0000 & 0.0000 & 0.0000 & 0.0000 & 0.0000 & 0.0000 & 0.0000 & 0.0000 & 0.0000 & 0.9000 & 0.0000 & 0.0000 & 0.0000 & 0.0000\end{array}$ $28.0 \quad 0.0000 \quad 0.0000 \quad 0.0000 \quad 0.0000 \quad 0.0000 \quad 0.0000 \quad 0 \quad v 000 \quad 0.0000 \quad 0.0000 \quad 0.0000 \quad 0.0000 \quad 0.0000 \quad 0.0000 \quad 0.0000 \quad 0.0000 \quad 0.0000$ ALL $0.0206 \quad 0.0514 \quad 0.03090 .0309 \quad 0.0308 \quad 0.0309 \quad 0.0205 \quad 0.1028 \quad 0.0206 \quad 0.0412 \quad 0.0309 \quad 0.0514 \quad 0.0925 \quad 0.0514 \quad 0.0206 \quad 0.0309$

$\begin{array}{llllllllllllllllll}1.5 & 0.0554 & 0.0507 & 0.0374 & 0.0621 & 0.0960 & 5.0665 & 0.0651 & 0.0977 & 0.0410 & 0.0618 & 0.0445 & 0.1126 & 0.0402 & 0.0208 & 0.0644\end{array}$

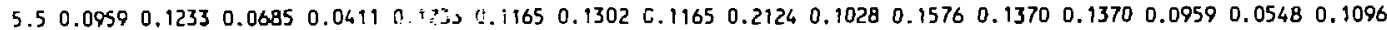

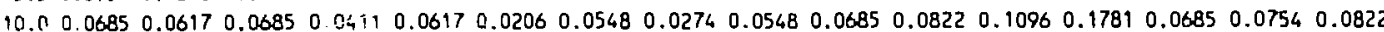

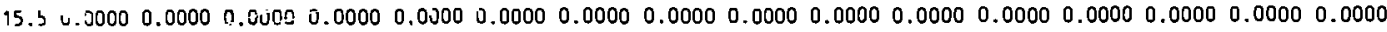
$\begin{array}{lllllllllllllllllll}21.5 & 0.0000 & 0.0000 & 0.0000 & 0.0000 & 0.0000 & 0.0000 & 0.0000 & 0.0000 & 0.0000 & 0.0000 & 0.0000 & 0.0000 & 0.0000 & 0.0000 & 0.0000 & 0.0000\end{array}$

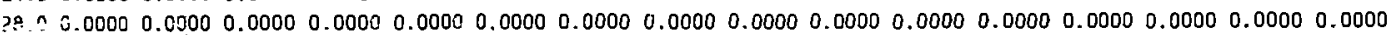
ALL $\begin{array}{llllllllllllllllllllll}0.2198 & 0.2357 & 0.1744 & 0.1243 & 0.2810 & 0.1795 & 0.2515 & 0.2090 & 0.3649 & 0.2123 & 0.3016 & 0.2911 & 0.4277 & 0.2046 & 0.1510 & 0.2562\end{array}$

\section{STABILITY CLASS 3}

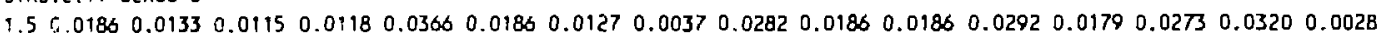

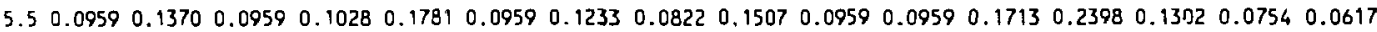
$\begin{array}{llllllllllllllllllll}10.0 & 0.2535 & 0.1850 & 0.1576 & 0.1713 & 0.2329 & 0.1918 & 0.1233 & 0.0822 & 0.1233 & 0.1987 & 0.3699 & 0.6439 & 0.4727 & 0.2261 & 0.1644 & 0.1576\end{array}$

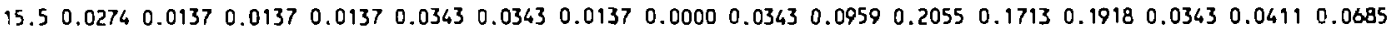
$\begin{array}{llllllllllllllllllllllllll}21.5 & 0.0000 & 0.0069 & 0.0000 & 0.0000 & 0.0000 & 0.0000 & 0.0000 & 0.0000 & 0.0137 & 0.0069 & 0.0343 & 0.0343 & 0.0411 & 0.0206 & 0.0000 & 0.0000\end{array}$ $\begin{array}{lllllllllllllllllllllllllll}28.0 & 0.0000 & 0.0000 & 0.0000 & 0.0000 & 0.0000 & 0.0000 & 0.0000 & 0.0000 & 0.0000 & 0.0000 & 0.0069 & 0.0137 & 0.0069 & 0.0000 & 0.0000 & 0.0000\end{array}$ $\begin{array}{lllllllllllllllllllllllllll}\text { ALL } & 0.3954 & 0.3559 & 0.2787 & 0.2996 & 0.4819 & 0.3406 & 0.2730 & 0.1681 & 0.3502 & 0.4160 & 0.7311 & 1.0637 & 0.9702 & 0.4385 & 0.3129 & 0.2906\end{array}$

\section{STABILITY CLASS 4}

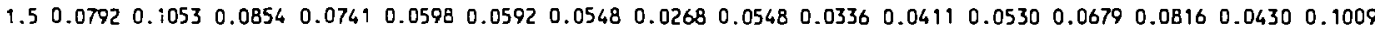
$\begin{array}{llllllllllllllllllllllllll}5.5 & 0.5412 & 0.5823 & 0.4453 & 0.3220 & 0.4110 & 0.3220 & 0.1918 & 0.1302 & 0.1918 & 0.1233 & 0.2055 & 0.3357 & 0.3357 & 0.2398 & 0.1439 & 0.4521\end{array}$ $\begin{array}{llllllllllllllllllllllllllll}10.0 & 1.1440 & 1.4249 & 1.0207 & 0.8768 & 0.9248 & 0.4932 & 0.3014 & 0.1370 & 0.2124 & 0.6302 & 1.4180 & 2.1304 & 1.7468 & 0.5412 & 0.5206 & 0.5001\end{array}$ $\begin{array}{lllllllllllllllllllllll}15.5 & 1.1097 & 1.4865 & 1.0275 & 0.6508 & 1.0001 & 0.5480 & 0.1987 & 0.0548 & 0.3699 & 3.0826 & 6.5420 & 5.1993 & 1.9318 & 0.9453 & 0.5891 & 0.4042\end{array}$

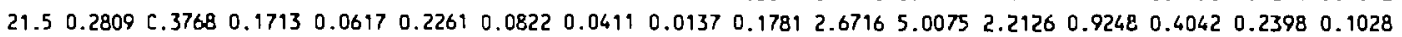
$\begin{array}{lllllllllllllllllllllllllllll}28.0 & 0.1028 & 0.1028 & 0.0274 & 0.0000 & 0.0137 & 0.0069 & 0.0000 & 0.0000 & 0.0411 & 1.4797 & 2.2469 & 0.9727 & 0.5206 & 0.1165 & 0.0411 & 0.0343\end{array}$ ALL $\quad 3.2578 \quad 4.078627776 \quad 1.98542 .6355 \quad 1.5115 \quad 0.7878 \quad 0.3625 \quad 1.0481 \quad 8.021015 .461010 .9037 \quad 5.5276 \quad 2.3286 \quad 1.5775 \quad 1.5944$ STABIL!TY CLASS 5

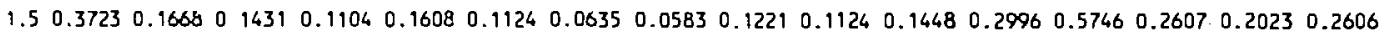
$\begin{array}{llllllllllllllllllllll}5.5 & 1.1098 & 0.8974 & 0.6439 & 0.5480 & 0.6234 & 0.3563 & 0.3083 & 0.1919 & 0.3014 & 0.3152 & 0.5275 & 1.2741 & 2.0140 & 0.9865 & 0.9042 & 0.9933\end{array}$ $\begin{array}{llllllllllllllllllllllllllll}10.0 & 0.3425 & 0.3014 & 0.2809 & 0.2877 & 0.4042 & 0.3083 & 0.1165 & 0.0480 & 0.0548 & 0.4042 & 1.0892 & 2.8223 & 1.9044 & 0.4042 & 0.2466 & 0.2603\end{array}$ $\begin{array}{llllllllllllllllllllllll}15.5 & 0.0000 & 0.0000 & 0.0000 & 0.0000 & 0.0000 & 0.0000 & 0.0000 & 0.0000 & 0.0000 & 0.0000 & 0.0000 & 0.0000 & 0.0000 & 0.0000 & 0.0000 & 0.0000\end{array}$ $\begin{array}{lllllllllllllllllllllll}21.5 & 0.9000 & 0.0000 & 0.0000 & 0.0000 & 0.0000 & 0.0000 & 0.0000 & c .0000 & 0.0000 & 0.0000 & 0.0000 & 0.0000 & 0.0000 & 0.0000 & 0.0000 & 0.0000\end{array}$ $\begin{array}{llllllllllllllllllll}28.0 & 0.0000 & 0.0000 & 0.0000 & 0.0000 & 0.0000 & 0.0000 & 0.0000 & 0.0000 & 0.0000 & 0.0000 & 0.0000 & 0.0000 & 0.0000 & 0.0000 & 0.0000 & 0.0000\end{array}$ ALL $1.8246 \quad 1.3656 \quad 1.0679 \quad 0.9661 \quad 1.188<\quad 0.7770 \quad 0.4883 \quad 0.2982 \quad 0.4783 \quad 0.8318 \quad 1.7615 \quad 4.39604 .4930 \quad 1.6514 \quad 1.3531 \quad 1.5142$

\section{STABILITY CLASS 6}

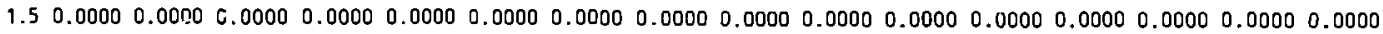
$\begin{array}{llllllllllllllllllllllll}5.5 & 0.0000 & 0.0000 & 0.0000 & 0.0000 & 0.0000 & 0.0000 & 0.0000 & 0.0000 & 0.0000 & 0.0000 & 0.0000 & 0.0000 & 0.0000 & 0.0000 & 0.0000 & 0.0000\end{array}$

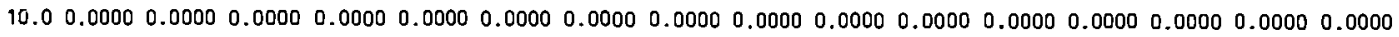

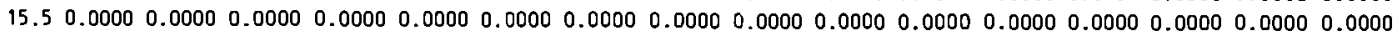
$\begin{array}{lllllllllllllllllllllllllll}21.5 & 0.0000 & 0.0000 & 0.0000 & 0.0000 & 0.0000 & 0.0000 & 0.0000 & 0.0000 & 0.0000 & 0.0000 & 0.0000 & 0.0000 & 0.0000 & 0.0000 & 0.0000 & 0.0000\end{array}$ $\begin{array}{llllllllllllllllllllllll}28.0 & 0.0000 & 0.0000 & 0.0000 & 0.0000 & 0.0000 & 0.0000 & 0.0000 & 0.0000 & 0.0000 & 0.0000 & 0.0000 & 0.0000 & 0.0000 & 0.0000 & 0.0000 & 0.0000\end{array}$ ALL $0.0000 \quad 0.0000 \quad 0.0000 \quad 0.0000 \quad 0.0000 \quad 0.0000 \quad 0.0000 \quad 0.0000 \quad 0.0000 \quad 0.0000 \quad 0.0000 \quad 0.0000 \quad 0.0000 \quad 0.0000 \quad 0.0000 \quad 0.0000$ 


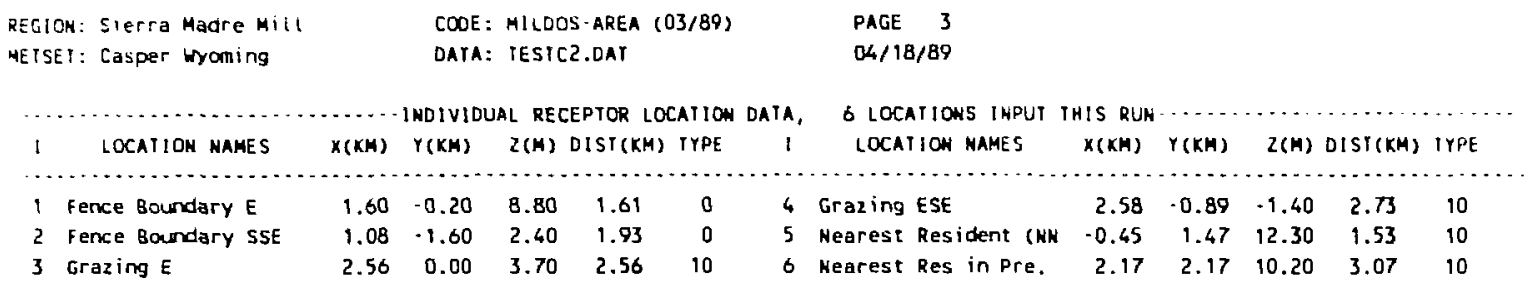

miscellameous Imputable parameter values

\begin{tabular}{|c|c|c|c|c|c|c|c|c|c|c|}
\hline DHM & DMA & ISIAR I & FFOR I & FHAY! & FFORP & FHAYP & FPR (1) & FPR (2) & FPR (3) & ACIRAT \\
\hline 150.0 & 1550.0 & 1980.00 & 0.50 & 0.50 & 0.50 & 0.50 & 320.00 & 1400.00 & 230.00 & 2.50 \\
\hline
\end{tabular}

IPACT EQUALS $0,0,0,1,2,3$,

Je equals $1,0,1,0,0,1,1,0,1,0$

STEP NAMES

1 After 2.25 rears

2 After 4.25 Years

3 After 0.50 Years

4 After 11.5 Years

5 After 19.5 Years

6 After 24.5 Years

$\begin{array}{cc}\text { LENGTH, YRS } & \text { IFTO0O } \\ 2.25 & 0 \\ 2.00 & 0 \\ 2.25 & 0 \\ 5.00 & 0 \\ 8.00 & 1 \\ 5.00 & 1\end{array}$

XRHO EQUALS $1.5,2.5, \quad 3.5, \quad \div .5,7.5,15.0,25.0,35.0,45.0,55.0,65.0,75.0$,

HDP EQUALS 50.0 
REGION: Sierra Madre Mill
MEISET: Casper Wyaming
COOE: MILDOS-AREA (O3/BO)

DAIA: TESTC2.DAT
PAGE 4

$04 / 18 / 80$

POPULATION DISTRIBUTIOH

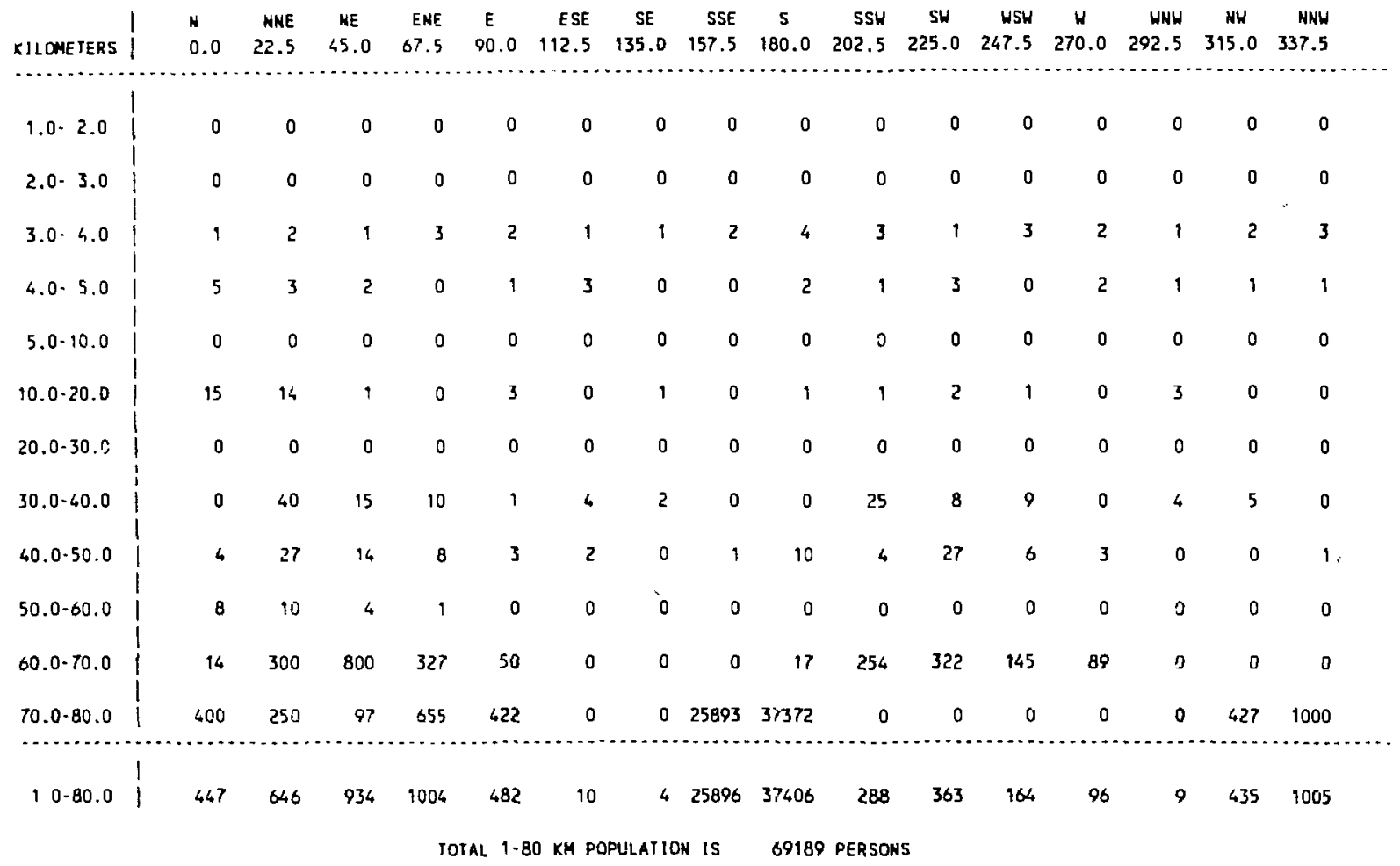


REGION: Sierra Madre Mill

METSET: Casper Wyoming
COOE: MILDOS-AREA (03/89)

DATA: TESTC2.DAT
PAGE 5

$04 / 18 / 89$

FINITE ELEMENT DATA FOR SOURCE NO. 4: IPX= 1 ID= 5001

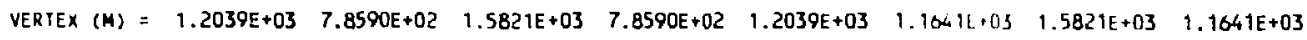

- AREA source ELEMEnt ho. = 1

AREA SOURCE ELEMENT NO. = 2

AREA SOURCE ELEMENT MO. = 3

$\begin{array}{lllll}\text { MOOES }= & 1 & 4 & 2 & 5 \\ \text { MOOES }= & 2 & 5 & 3 & 6 \\ \text { HOOES }= & 4 & 7 & 5 & 8 \\ \text { MOOES }= & 5 & 8 & 6 & 9\end{array}$

MOOAL COORDINATES (M):

NOOE HO. =

HODE NO. = 3

$X S=1.2039 E+03$

$X S=1.203 \% E+03$

NODE NO. $=3 \quad X S=1.2039 E+03$

NOOE NO. $=4 \quad X S=1.3930 E+03$

NODE NO. $=5 \quad X S=1.3930 E+03$

NOOE HO. $=6 \quad X S=1.3930 E+03$

NOOE HO. $=7 \quad X S=1.5821 E+03$

MOOE NO. $=8 \quad X S=1.582 \mathrm{iE}+03$

$Y S=7.8590 E+02$

$Y S=9.7500 E+02$

$Y S=1.1641 E+03$

$Y S=7.8590 E+02$

$Y S=9.7500 E+02$

$Y S=1.1641 \mathrm{E}+03$

$Y S=7.8590 E+02$

$Y S=9.7500 E+02$

NCOE HO. $=$ ?

$X S=1.5821 E+03$

$Y S=1.1641 E+03$ 
REGION: Sierra Madre Mill

MEISEI : Casper Hroming
COOE : MILDOS-AREA (03/89)

DATA: IESTC2.DAT
PAGE 6

$04 / 18 / 89$

FINITE ELEMEAT DATA FOR SOURCE HO, 5: IPX= $2 \quad 10=5002$

\begin{tabular}{|c|c|c|c|c|c|c|}
\hline \multicolumn{4}{|c|}{ VERTEX $(M)=-1.5598 E+03-1.1038 E+03$} & $.0402 E+03$ & \\
\hline REA SOURCE & ELEHENT & NO. $=$ & 1 & NODES= & 1 & \\
\hline REA SQURCE & ELEMEMT & No. $=$ & 2 & HODES $=$ & 2 & \\
\hline REA SOURCE & ELEHEHT & MO. $=$ & 3 & MOOES= & 4 & \\
\hline REA SQURCE & ELEMENT & Mo. = & 4 & HOOES= & 5 & \\
\hline \multicolumn{7}{|c|}{ DOAL COORDIHATES (H): } \\
\hline NOOE MO. = & 1 & $\times 5=$ & -1.55 & $Y S=-$ & \multicolumn{2}{|c|}{$-1.1038 E+03$} \\
\hline NOOE NO. = & 2 & $x S=$ & $-1.5598 E+03$ & $Y S=$ & \multicolumn{2}{|c|}{$-8.4400 E+02$} \\
\hline HOOE MO. = & 3 & $x 5=$ & $-1.5598 \mathrm{gE}+03$ & $\mathrm{YS}=$. & \multicolumn{2}{|c|}{$-5.8420 E+02$} \\
\hline HOOE NO. = & 4 & $x S=$ & $-1.3000 E+03$ & $Y S=-$ & \multicolumn{2}{|c|}{$-1.1038 E+03$} \\
\hline NOOE HO. = & 5 & $X S=$ & $-1.3000 E+03$ & $r S=\cdot$ & \multicolumn{2}{|c|}{$-8.4400 E+02$} \\
\hline NOOE NO. = & 6 & $\times 5=$ & $-1.3000 E+03$ & $Y S=-$ & \multicolumn{2}{|c|}{$-5.8420 E+02$} \\
\hline KODE HO. = & 7 & $\mathbf{x S}=$ & $-1.0402 E+03$ & $Y S=$. & \multicolumn{2}{|c|}{$-1.1038 E+03$} \\
\hline HOOE NO. = & 8 & $x S=$ & $-1.0402 E+03$ & $r_{S}=-$ & \multicolumn{2}{|c|}{$-8.4400 E+02$} \\
\hline HOOE NO. = & 9 & $x S=$ & $-1.0402 E+03$ & $Y S=-$ & \multicolumn{2}{|c|}{$-5.8420 E+$} \\
\hline
\end{tabular}


REGION: Sierra Madre Mill

MEISEI : Casper Hroming
COOE: MILDOS-AREA (03/89)

DATA: IESIC2.DAT
PAGE 7

$04 / 18 / 89$
FIHIYE ELEHEHI DATA FOR SOURCE NO. 6 :

\begin{tabular}{|c|c|c|c|}
\hline AREA SOURCE & \multicolumn{2}{|c|}{ ELEKENT NO. = } & 1 \\
\hline REA SOURCE & ELEKENT & MO. = & 2 \\
\hline EA SOURCE & ELEKENT & NO. = & 3 \\
\hline EA SOURCE & ELEMENT & NO. = & 4 \\
\hline EA SQUREE & ELEHENT & No. $=$ & 5 \\
\hline DAL CO & 1 & H & \\
\hline MOOE HO. = & 1 & $x \mathbf{S}=$ & $1.2000 E+03$ \\
\hline HODE HO. = & 2 & $\times 5=$ & $1.6000 E+03$ \\
\hline NODE NO. = & 3 & $\times 5=$ & $1.2000 E+03$ \\
\hline NOOE NO. = & 4 & $\mathrm{xS}=$ & $1.6000 E+03$ \\
\hline NODE NO. = & 5 & $x S=$ & $1.2000 E+03$ \\
\hline NOOE NO. = & 6 & $x S=$ & $1.6000 E+03$ \\
\hline NOOE NO. = & 7 & $x S=$ & $2.0000 E+02$ \\
\hline NOOE HO. = & 8 & $x S=$ & B. $0000 E+02$ \\
\hline HODE HO. = & 9 & $x 5=$ & $1.2000 E+03$ \\
\hline HOOE NO. = & 10 & $\mathrm{xS}=$ & $1.6000 E+03$ \\
\hline MOOE NO. = & 11 & $x S=$ & $6.0000 E+02$ \\
\hline HOOE NO. = & 12 & $\times S=$ & B. $0000 E+02$ \\
\hline NOOE NO. = & 13 & $x S=$ & $1.0000 E+03$ \\
\hline
\end{tabular}

$1 P X=3 \quad 10=5003$

$\begin{array}{rrrrr}\text { MOOES }= & 1 & 2 & 3 & 4 \\ \text { MOOES }= & 3 & 4 & 5 & 6 \\ \text { NOOES }= & 5 & 6 & 9 & 10 \\ \text { NOOES }= & 7 & 8 & 11 & 12 \\ \text { NOOES }= & 8 & 10 & 12 & 13\end{array}$

$Y S=-2.2000 E+03$

$Y S=-1,8000 E+03$

$Y S=-1.6000 E+03$

$Y S=-1.6000 E+03$

$Y S=-1.2000 E+03$

$Y S=-1.2000 E+03$

$Y S=-8.0000 E+02$

$Y S=-8.0000 E+02$

$Y S=-8.0000 E+02$

$Y S=-8.0000 E+02$

$Y S=-4,0000 E+02$

$Y S=-4.0000 E+02$

$Y S=-4.0000 E+02$ 
REGIOH: SIerta Madre Mill

METSET: Casper Hyoming
COOE: MILI:ZS-AREA (03/89)

DATA: IESICZ.DAT
PAGE 8

$04 / 18 / 89$

NUMBER OF SOURCES $=6$

\begin{tabular}{|c|c|c|c|c|c|c|c|c|c|c|c|c|c|}
\hline & $\mathbf{K M}$ & 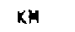 & M & KM2 & & & CI/TEAR & & & & PSIZE & $\mathrm{M} / \mathrm{SEC}$ & \\
\hline nO. & $x$ & $r$ & 2 & AREA & $U-238$ & $T h-230$ & $8 a \cdot 226$ & $P b-210$ & $R n-222$ & 10 & SEI & EXII VEL & SOURCE HAME \\
\hline 1 & 0.00 & 0.00 & 20.00 & 0.0000 & 6. $14 \mathrm{E}-02$ & $2.16 E-03$ & $8.62 E-05$ & $8.62 E-05$ & $0.00 E+00$ & 1101 & 1 & $1.70 E+01$ & rellowcake stack \\
\hline 2 & $0 . \div 0$ & 0.40 & 6.00 & 0.1600 & $4.08 \mathrm{E}-02$ & 4. $.08 E-02$ & $4.08 E \cdot 02$ & $4.08 \mathrm{E}-02$ & $1.09 E+03$ & 1201 & 3 & $0.00 E+00$ & Ore Pad \\
\hline 3 & 0.20 & 0.20 & 0.00 & 0.0000 & $2.60 E \cdot 02$ & $2.60 E-02$ & $2.60 \mathrm{E}-02$ & $2.60 E \cdot 02$ & $4.16 E+01$ & 1301 & 2 & $0.00 E+00$ & Grizzly Dump-Hopper \\
\hline i & 1.39 & 0.98 & -10.00 & 0.1630 & $5.67 E-03$ & $1.35 E-01$ & $1.41 E \cdot 01$ & $1.41 E \cdot 01$ & $1.28 \mathrm{E}+03$ & 5001 & 3 & $0.00 E+00$ & Iailings nrea 1 \\
\hline 5 & $\cdot 1.30$ & -0.84 & -10.00 & 0.2700 & $1.61 \mathrm{E}-02$ & $3.82 E-01$ & $6.01 E-01$ & $4.01 E-01$ & $3.64 E+03$ & 5002 & 3 & $0.00 E+00$ & Tailings Area ? \\
\hline$s$ & 9.00 & -0.08 & -10.00 & $0.8<, 00$ & $0.50 E-02$ & $1.58 E+00$ & $1.67 E+00$ & $1.67 E+00$ & $1.51 E+04$ & 5003 & 3 & $0.00 E+00$ & Taitings Area 3 \\
\hline
\end{tabular}

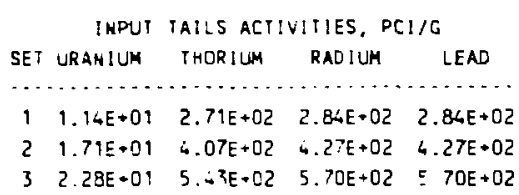

\begin{tabular}{|c|c|c|c|c|}
\hline AMAD & AMD FRAC & TI INAL & DISTRIB & QUT10H \\
\hline SET & 1.5 & 3.0 & 7.7 & 54.0 \\
\hline & & & & \\
\hline 1 & 0.000 & 1.000 & 0.000 & 0.000 \\
\hline 2 & 1.000 & 0.000 & 0.000 & 0.000 \\
\hline 3 & 0.000 & 0.000 & 0.300 & 0.700 \\
\hline
\end{tabular}

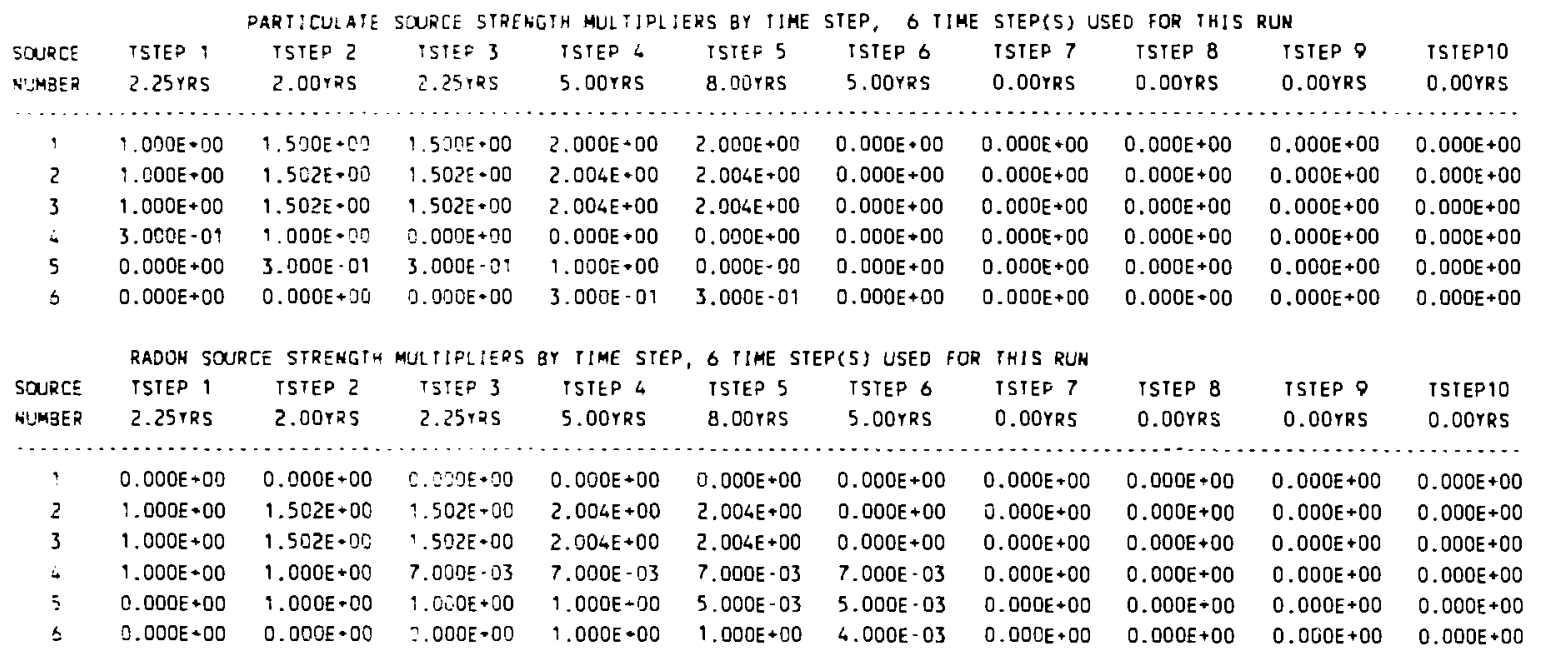


REGION: Sierra Madre Mill METSET: Casper Hyoming
COOE : MILDOS-AREA $(03 / 89)$ DATA: TESTCZ.DAT
PAGE 37

$04 / 18 / 89$

TIME STEP MUHBER 5, After 19.5 Years

DURATIUH IN YRS $15 \ldots 8.0$

COMCENTRATION DATA IOR THE h OIRECIION, THETA EQUALS 0.0 DEGREES

TOTAL AIR CONCENTRAIIONS, PCI/M3, AHO WL

\begin{tabular}{|c|c|c|c|c|c|c|c|c|c|c|}
\hline \multirow{2}{*}{ KRHO， KM } & \\
\hline & $U-238$ & $T h-230$ & $28-226$ & $\mathrm{~Pb}-210$ & $\mathrm{Rn}-222$ & Po- 218 & $\mathrm{~Pb} \cdot 214$ & $8 \mathrm{i}-214$ & $P b-210$ & $\mathbf{H L}$ \\
\hline & & & & & & & & & & \\
\hline 1.5 & $1.391 \mathrm{E}-. ;$ & $8.375 \mathrm{E}-06$ & $8.082 E-04$ & $8.063 E-06$ & $5.565 E+01$ & $5.090 E+01$ & $2.034 E+01$ & $9.642 E+00$ & $1.334 E-05$ & $1.915 E-04$ \\
\hline 2.5 & $5.608 \mathrm{E}-04$ & $2.901 E-04$ & $2.758 E-04$ & $2.751 E-04$ & $2.819 E+01$ & $2.740 E+01$ & $1.491 E+01$ & $8.982 E+00$ & $1.833 E-05$ & $1.373 \mathrm{E}-04$ \\
\hline 3.5 & $3.205 E-04$ & $1.640 E-04$ & $1.558 E-04$ & $1.554 E-04$ & $1.972 E+01$ & $1.946 E+01$ & $1.226 \mathrm{E}+01$ & $8.339 E+00$ & $2.334 E-05$ & $1.133 E-04$ \\
\hline 4.5 & $2.087 E-04$ & $1.081 E-04$ & $1.028 E-04$ & $1.025 E-04$ & $1.500 E+01$ & $1.480 \mathrm{E}+01$ & $1.029 E+01$ & $7.510 E+00$ & $2.716 E-05$ & $9.555 E-05$ \\
\hline 7.5 & $8.466 \varepsilon-05$ & $4.603 E-05$ & $4.399 E-05$ & $4.388 E-05$ & $8.192 E+00$ & $8.183 E+00$ & $6.561 E+00$ & $5.301 E+00$ & $3.265 E-05$ & $6.147 E-05$ \\
\hline 15.0 & $2.388 E-05$ & $1.444 E-05$ & $1.394 E-05$ & $1.390 E-05$ & $3.438 E+00$ & $3.440 E+00$ & $3.153 E+00$ & $2.834 E+00$ & $3.434 E-05$ & $3.010 E-05$ \\
\hline 25.0 & $9.103 E-06$ & $5.936 E-06$ & S.769E-0.6 & $5.755 E \cdot 06$ & $1.698 E+00$ & $1.699 \mathrm{E}+00$ & $1.649 E+00$ & $1.577 E+00$ & $3.222 E-05$ & $1.599 E-05$ \\
\hline 35.0 & $4.823 E-06$ & $3.310 E-06$ & $3.230 \mathrm{E}-0.6$ & $3.222 E-06$ & $1.062 E+00$ & $1.062 E+00$ & $1.050 E+00$ & $1.02 B E+00$ & $3.000 E-05$ & $1.026 E-0 S$ \\
\hline 45.0 & $3.008 E-06$ & $2.139 E-06$ & $2.093 E-06$ & $2.088 E-06$ & $7.440 E-01$ & $7.445 E-01$ & $7.421 E-01$ & $7.343 E-01$ & $2.807 E-05$ & $7.268 E-06$ \\
\hline 55.0 & $2.066 E-06$ & $1.519 \mathrm{E} \cdot 06$ & $1.490 \mathrm{E}-06$ & $1.486 E-06$ & $5.640 E-01$ & $5.644 E-01$ & $5.645 E-01$ & $5.616 E-01$ & $2.645 E-05$ & $5.538 E-06$ \\
\hline 65.0 & $1.512 E-06$ & $1.132 E-06$ & $1.112 \mathrm{E}-06$ & $1.109 E-06$ & $4.412 E-01$ & $4.415 E-01$ & $4.425 E-01$ & $4.418 \mathrm{E} \cdot 01$ & $2.502 E-05$ & $4.346 E-06$ \\
\hline 75.0 & $1.158 E-06$ & $8.795 E \cdot 07$ & $8.648 E-07$ & B. $627 \mathrm{E}-07$ & $3.56 .8 E-01$ & 3.5 JTE-01 & $3.583 E-0.7$ & $3.585 E-07$ & $2.378 E-05$ & $3.521 E-D 6$ \\
\hline
\end{tabular}

GROUHD SURFACE CONCENTRATIONS, PCI/MZ

\begin{tabular}{|c|c|c|c|c|c|c|c|c|c|}
\hline$X R H O, K M$ & $u \cdot 238$ & $T h-230$ & Ra. 226 & $\mathrm{~Pb}-210$ & Rn- 222 & Po- 218 & Pb-214 & Bi-214 & Pb- 210 \\
\hline 1.5 & $7.740 E+03$ & 2. $108 \mathrm{BE}+04$ & $2.167 E+04$ & $2.167 E+04$ & $0.000 E+00$ & $2.171 E+04$ & $2.171 E+04$ & $2.171 E+04$ & $1.512 E+01$ \\
\hline 2.5 & $2.610 E+03$ & $8.381 E+03$ & $8.638 E+03$ & $8.638 E+03$ & $0.000 E+00$ & $8.660 E+03$ & $8.660 E+03$ & $8.660 E+03$ & $2.033 E+01$ \\
\hline 3.5 & $1.408 \mathrm{E}+03$ & $4.323 E+03$ & $4.453 E+03$ & $4.453 E+03$ & $0.000 E+00$ & $4.46 .8 E+03$ & $4.468 E+03$ & $4.468 E+03$ & $2.564 E+01$ \\
\hline 4.5 & $8.810 E+02$ & $2.548 E+03$ & $2.622 E+03$ & $2.622 E+03$ & $0.000 E+00$ & $2.634 E+03$ & $2.634 E+03$ & $2.634 E+03$ & $2.969 E+01$ \\
\hline 7.5 & 3. $329 E+02$ & $8.261 E+02$ & $8.478 E+02$ & $8.478 E+02$ & $0.000 E+00$ & $8.543 E+02$ & $8.543 E+02$ & $8.543 E+02$ & $3.554 E+01$ \\
\hline 15.0 & B. $756 E+01$ & $1.741 E+02$ & $1.779 E+02$ & $1.779 E+02$ & $0.000 \Sigma+00$ & $1.806 E+02$ & $1.806 E+02$ & 1.806E+02 & $3.721 E+01$ \\
\hline 25.0 & $3.210 E+01$ & $5.322 E+01$ & $5.410 E+01$ & $5.410 E+01$ & $0.000 E+00$ & $5.544 E+01$ & $5.544 E+01$ & $5.544 E+01$ & $3.483 E+01$ \\
\hline 35.0 & $1.669 E+01$ & $2.487 E+01$ & $2.519 E+01$ & $2.519 E+01$ & $0.000 E+00$ & $2.603 E+01$ & $2.603 E+01$ & $2.603 \mathrm{E}+01$ & $3.239 E+01$ \\
\hline 45.0 & $1.029 E+01$ & $1.424 E+01$ & $1.439 E+01$ & $1.439 E+01$ & $0.000 E+00$ & $1.498 E+01$ & $1.498 E+01$ & $1.498 \mathrm{E}+01$ & $3.028 E+01$ \\
\hline 55.0 & $7.001 E+00$ & $9.315 E+00$ & $9.400 E+00$ & $9,400 E+03$ & $0.000 E+00$ & $9.847 E+00$ & $9.847 E+00$ & $9.847 E+00$ & $2.853 E+01$ \\
\hline 65.0 & $5.080 E+00$ & $6.454 E+00$ & $6.500 E+00$ & $6.500 E+00$ & $0.000 E+00$ & $6.850 E+00$ & $6.850 E+00$ & $6.850 E+00$ & $2.698 E+01$ \\
\hline 75.0 & 3. $860 E+00$ & $4.729 E+00$ & 4. $756 E+00$ & 4. $756 E+00$ & $0.000 E+00$ & $5.039 E+00$ & $5.039 E+00$ & $5.039 E+00$ & 2.5SAE-01 \\
\hline
\end{tabular}

\begin{tabular}{|c|c|c|c|c|}
\hline \multirow[b]{2}{*}{ XRHO， KM } & \multicolumn{4}{|c|}{ TOTAL DEPOSITION RATES, PCI/M2-SEL } \\
\hline & $u-238$ & $T h-230$ & $R a-226$ & $\mathrm{~Pb}-210$ \\
\hline 15 & $7309 F-05$ & $20385-05$ & $? 0185-05$ & ? $017 F-05$ \\
\hline 3 & 797604 & $6.0275-06$ & $6347-06$ & $2.017-0 \mathrm{C}$ \\
\hline 2.5 & $7.874 E-06$ & $6.427 E-06$ & $6.347 E-06$ & $6.388 E-06$ \\
\hline 3.5 & 4. $283 E-06$ & $3.657 \mathrm{E} \cdot 06$ & $3.622 E-06$ & $3.684 E-06$ \\
\hline 4.5 & $2.706 E-06$ & $2.424 E-06$ & $2.408 E-06$ & $2.484 \mathrm{E}-06$ \\
\hline 7.5 & $1.046 E-06$ & $1.025 E-06$ & $1.024 E-06$ & $1.120 E-06$ \\
\hline 15.0 & $2.825 E-0 ?$ & $3.045 E-07$ & $3.057 E-c 7$ & $4.080 E-07$ \\
\hline 25.0 & $1.052 E-07$ & $1.145 E-07$ & $1.149 \mathrm{E}-07$ & $2.113 E-07$ \\
\hline 35.0 & $5.509 E-08$ & $5.956 \mathrm{E}-\mathrm{OB}$ & $5.980 E-08$ & $1.696 E-07$ \\
\hline 45.0 & $3.408 E-08$ & $3.642 E-08$ & $3.654 E-08$ & $1.207 \mathrm{~T}-07$ \\
\hline 55.0 & $2.325 E-08$ & $2.483 E-08$ & $2.491 E-08$ & $1.042 E-07$ \\
\hline 65.0 & $1.690 \mathrm{E}-0 \mathrm{~B}$ & $1.776 E-O B$ & $1.780 E-08$ & $9.282 E-08$ \\
\hline$\pi .0$ & $1.286 \mathrm{E}-08$ & $1.332 \mathrm{E}-08$ & $1.334 E-08$ & $8.665 E-08$ \\
\hline
\end{tabular}


REGION: Sierra Madre Mill METSET: Casper Uyoming
COOE: MILDOS-AREA (03/89)

DATA: TESTCZ.DAT
PAGE 41

$04 / 18 / 89$

TIME STEP NUMBER S, After 19.5 Years

DURATIOH IN YRS IS... 8.0

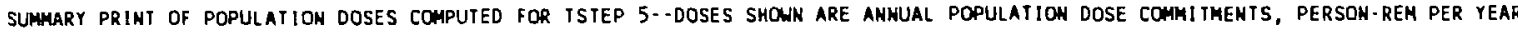

DOSES RECEIVEO GY PEOPLE WITHIN 80 KILOMETERS

\begin{tabular}{|c|c|c|c|c|c|c|}
\hline PATHUAY & EFFECTIV & BONE & AVG.LUMG & LIVER & KIDNEY & BRONCHI \\
\hline$\cdots$ & $\cdots \cdots$ & 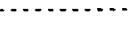 & ${ }^{2}$ & & & 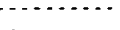 \\
\hline IHHAL. & $7.426 E-01$ & $5.003 E+00$ & $2.613 E+00$ & $1.866 \mathrm{E}+00$ & $9.254 E-01$ & $9.518 E+01$ \\
\hline GROUND & $2.689 E-01$ & $2.689 E-01$ & $2.689 E-01$ & $2.689 E-01$ & $2.689 E-01$ & $2.689 E-01$ \\
\hline ClaUD & $7.939 E-01$ & $7.939 E-01$ & $7.939 \mathrm{E} \cdot 01$ & $7.939 E-01$ & $7.939 \mathrm{E}-01$ & $7.939 E-01$ \\
\hline VEG. ING & 4. $877 E+00$ & $5.825 E+01$ & $4.877 \mathrm{E}+00$ & $1.478 E+01$ & $1.236 E+01$ & $4.877 E+00$ \\
\hline MEAT IHG & $6.719 E-01$ & $8.235 E+00$ & $6.719 E-01$ & $2.145 E+00$ & $1.758 E+00$ & $6.719 E-01$ \\
\hline MILK ING & $1.913 E-01$ & $2.565 \mathrm{E}+00$ & $1.913 E-01$ & $3.809 E-01$ & $3.843 E-01$ & $1.913 E-01$ \\
\hline RKPLUS50 & $0.000 E+00$ & $0.000 E+00$ & $0.000 \mathrm{E}+00$ & $\overline{0} .000 E+00$ & $0.000 \mathrm{E}+00$ & $0.000 E+00$ \\
\hline TOTALS & $7.545 E+00$ & $7.512 \mathrm{E}+01$ & $9.415 E+00$ & $2.024 E+01$ & $1.649 \mathrm{E}+01$ & $1.020 E+02$ \\
\hline
\end{tabular}

DOSES RECEIVED BY PEOPLE BEYOND 80 KILOMETERS

\begin{tabular}{|c|c|c|c|c|c|c|}
\hline PATHUAY & EFFECIIV & BONE & AVG.LUHG & LIVER & KIONEY & BRONCHI \\
\hline$\cdots$ & - & 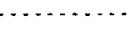 & ses & & * . & $\ldots \ldots . . .$. \\
\hline INHAL. & $0.000 E+00$ & $0.000 E+00$ & $0.000 E+00$ & $0.000 E+00$ & $0.000 E+00$ & $0.000 E+00$ \\
\hline GROUND & $0.000 E+00$ & $0.000 E+00$ & $0.000 E+00$ & $0.000 E+00$ & $0.000 E+00$ & $0.000 E+00$ \\
\hline CLOND & $0.000 E+00$ & $0.000 E+00$ & $0.000 E+00$ & $0.000 E+00$ & $0.000 E+00$ & $0.000 E+00$ \\
\hline VEG. ING & $0.000 E+00$ & $0.000 E+00$ & $0.000 E+00$ & $0.000 E+00$ & $0.000 E+00$ & $0.000 E+00$ \\
\hline MEAT ING & $1.987 E+00$ & $2.435 E+01$ & $1.987 E+00$ & $6.342 E+00$ & $5.197 \mathrm{E}+00$ & $1.987 E+00$ \\
\hline MILK ING & $0.000 E+00$ & $0.000 E+00$ & $0.000 E+00$ & $0.000 E+00$ & $0.000 E+00$ & $0.000 E+00$ \\
\hline RNPLUS50 & $1.760 E+02$ & $2.393 E+03$ & 4. $000 E+01$ & $1.760 \mathrm{E}+02$ & $1.760 E+02$ & $1.151 E+03$ \\
\hline \multicolumn{7}{|c|}{ 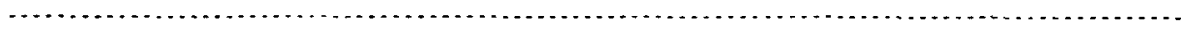 } \\
\hline IOTALS & $1.779 E+02$ & $2.418 \mathrm{E}+03$ & 4. $199 \mathrm{E}+01$ & $1.823 E+02$ & $1.812 \mathrm{E}+02$ & $1.153 \mathrm{E}+03$ \\
\hline
\end{tabular}

TOTAL DOSES COMPUTED OVER ALL POPULATIONS

\begin{tabular}{|c|c|c|c|c|c|c|}
\hline PATHUAY & EFFECTIV & BONE & AVG.LUHG & LIVER & KIDHEY & BROHCHI \\
\hline \multicolumn{7}{|c|}{ 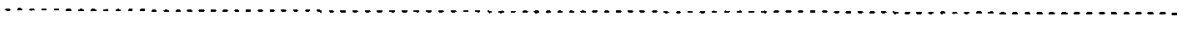 } \\
\hline INHAL. & $7.426 \mathrm{E}-01$ & $5.003 E+00$ & $2.613 E+00$ & $1.866 \mathrm{E}+00$ & $9.254 E-01$ & $9.518 E+01$ \\
\hline GROUND & $2.689 \mathrm{E}-01$ & $2.689 \mathrm{E}-01$ & $2.689 \mathrm{E}-01$ & $2.689 \mathrm{E}-01$ & $2.689 E-01$ & 2. $689 E-01$ \\
\hline ELOUD & $7.939 E-01$ & $7.939 E-01$ & $7.939 E-01$ & $7.939 \mathrm{E}-01$ & $7.939 E-01$ & $7.939 E-01$ \\
\hline VEG. ING & $4.877 \mathrm{E}+00$ & $5.825 E+0 T$ & $4.877 \mathrm{E}+00$ & $1.478 E+01$ & $1.236 E+01$ & $4.877 E+00$ \\
\hline MEAT ING & $2.659 E+00$ & 3. $258 E+01$ & $2.659 \mathrm{E}+00$ & $8.486 E+00$ & $6.955 E+00$ & $2.659 E+00$ \\
\hline MILK ING & $1.913 E-01$ & $2.565 \mathrm{E}+00$ & $1.913 E-01$ & $3.809 \mathrm{E}-01$ & $3.843 E-01$ & $1.913 E-01$ \\
\hline RHPLUS50 & $1.760 E+02$ & $2.393 E+03$ & $4.000 E+01$ & $1.760 E+02$ & $1.760 E+02$ & $1.954 E+03$ \\
\hline \multicolumn{7}{|c|}{ 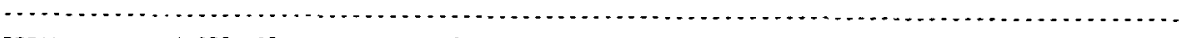 } \\
\hline TOTALS & $1.855 E+02$ & $2.493 E+03$ & $5.160 \mathrm{E}+03$ & $2.025 E+02$ & $1.97 \Delta E+02$ & $1.255 E+03$ \\
\hline
\end{tabular}


REGION: Sierta Madre Mill MEISET: Casper Hyoming
CODE: MILDOS-AREA $(03 / 80)$

DATA: IESTC2.DAT

IIME STEP NUMBER 5, After 19,5 rears
PAGE 42

$04 / 18 / 89$

DURATION IN YRS IS... 8.0

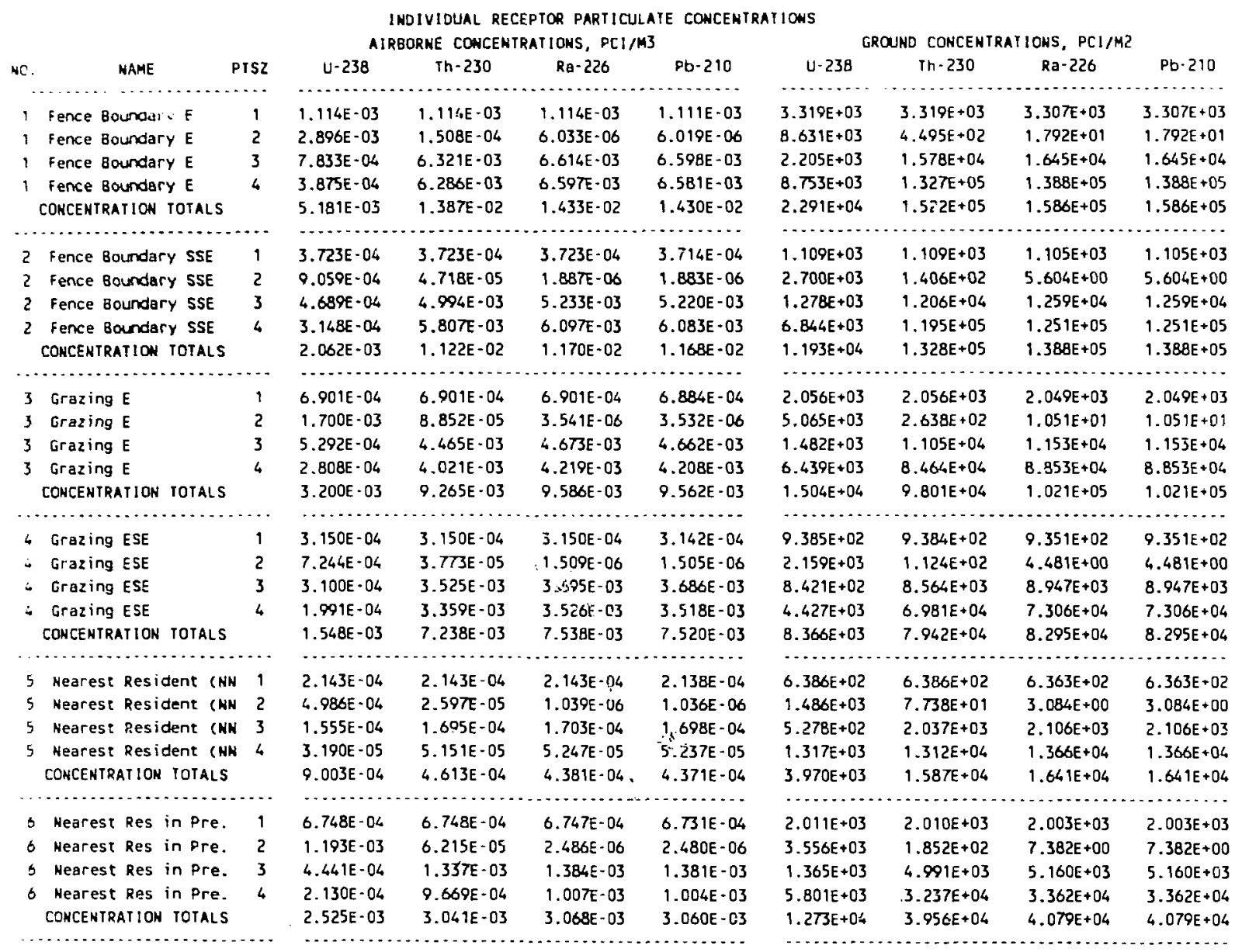


REGION: Sierra Hadre Hill METSET: Casper Wyoming
CODE : MILDOS-AREA $(03 / 89)$

DATA: TESTCZ.DAT

TIME SIEP NUMBER 5, After 19.5 reBrs
PAGE 43

$04 / 18 / 89$

INDIVIDUAL RECEPIOR RADON ANO RADOW DAUGHTER CONCENIRATIONS AIRBORHE COHCENTRATIONS, PCi/H3

GRONHD CONCENTRATIONS, PC, ;'H2

HO. Rn-222 PO-218 PO-216 Bi-214 Pb-210 Bi-210 PO-210 Pb-210

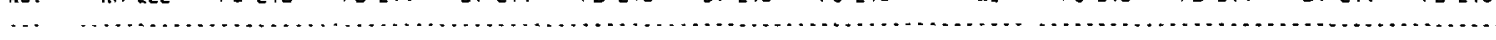

$1 \quad 8.745 E+02 \quad 5.656 E+02 \quad 1.035 E+02 \quad 2.693 E+01 \quad 1.412 E-05 \quad 1.026 E-08 \quad 2.389 E-13 \quad 1.208 E-03 \quad 4.480 E+02 \quad 4.480 E+02 \quad 4.480 E+02 \quad 2.185 E+01$

$2 \quad 3.753 E+03 \quad 1.277 \mathrm{E}+03 \quad 1.301 \mathrm{E}+02 \quad 2.731 \mathrm{E}+01 \quad 1.429 \mathrm{E}-05 \quad 1.193 \mathrm{E}-08 \quad 3.390 \mathrm{E}-13 \quad 2.076 \mathrm{E}-03 \quad 1.011 \mathrm{E}+03 \quad 1.011 \mathrm{E}+03 \quad 1.011 \mathrm{E}+03 \quad 2.060 \mathrm{E}+01$

$34.507 E+023.445 E+02 \quad 8.383 E+01 \quad 3.202 E+013.084 E-05 \quad 3.811 E-08 \quad 1.405 E-12 \quad 8.993 E-042.729 E+02 \quad 2.729 E+02 \quad 2.729 E+02 \quad 3.980 E+01$

$4 \quad 0.85 B E+025.247 E+02 \quad 1.293 E+C 2+4.4 B 5 E+013.605 E-05 \quad 3.962 E-08 \quad 1.376 E-12 \quad 1.363 E-034.156 E+024.156 E+02 \quad 4.156 E+02 \quad 4.074 E+01$

$5 \quad 5.001 E+01 \quad 4.635 E+01 \quad 1.912 E+01 \quad 9.435 E+00 \quad 1.418 E-05 \quad 2.871 E-08 \quad 1.758 E-12 \quad 1.799 E-04 \quad 3.671 E+01 \quad 3.671 E+01 \quad 3.671 E+01 \quad 1.576 E+01$

$6 \quad 1.045 E+02 \quad 8.994 E+01 \quad 2.909 E+01 \quad 1.466 E+01 \quad 2.703 E-05 \quad 6.206 E-08 \quad 4.138 E+12 \quad 2.952 E-047.124 E+017.124 E+01 \quad ; .124 E+01 \quad 3.067 E+01$ 


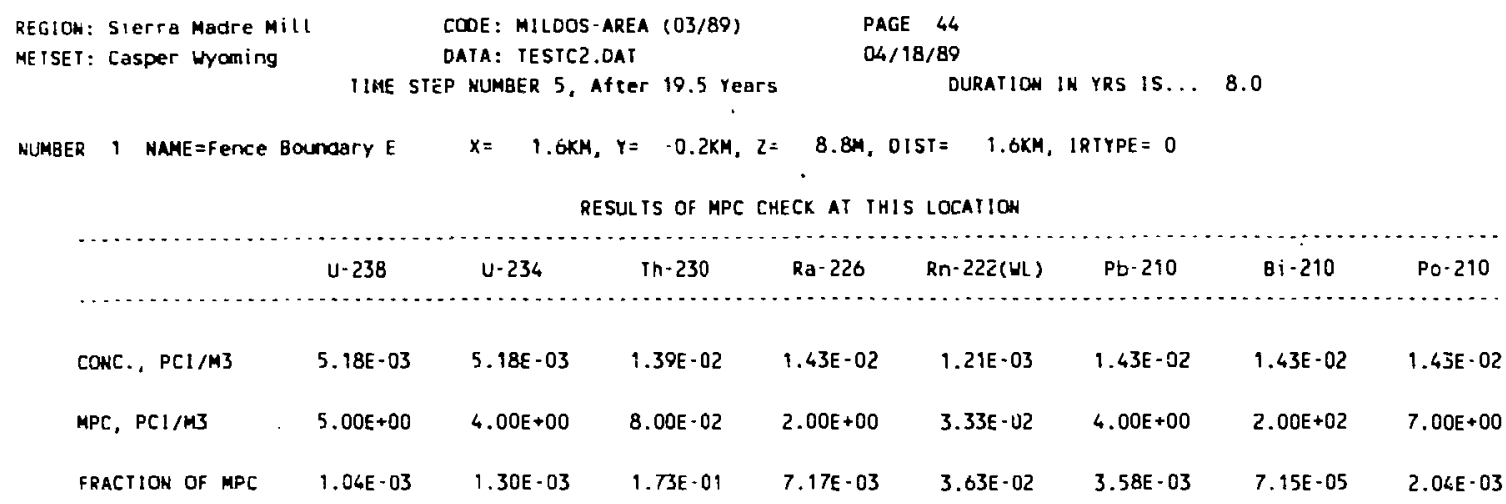

SUM OF FRACTIONS EQUALS 2.25E-01

NUMBER 2 NAME $=$ Fence Boundary SSE $X=1.1 \mathrm{KM}, Y=-1.6 \mathrm{KM}, Z=2.4 \mathrm{M}$, DIST $=1.9 \mathrm{KM}, I R T Y P E=0$

RESULTS OF MPC CHECK AT THIS LOCATION

\begin{tabular}{|c|c|c|c|c|c|c|c|c|}
\hline & U-238 & $\mathrm{U}-234$ & Th-230 & . 735 & $R \cap-222(H L)$ & Pb- 210 & Bi-210 & Po. 210 \\
\hline $\mathrm{COHC}$., $\mathrm{PCl} / \mathrm{MB}$ & $2.06 E-03$ & $2.06 E \cdot 03$ & $1.12 E-02$ & $1.17 E-02$ & $2.08 E-03$ & $1.17 \mathrm{E}-02$ & $1.17 E-02$ & $1.17 E-02$ \\
\hline$M P C, P C 1 / M 3$ & $5.00 E+00$ & $4.00 E+00$ & 8.00E-02 & $2.00 E+00$ & $3.33 E-02$ & $4.00 E+00$ & $2.00 E+02$ & 7.DOE +0D \\
\hline FRACIION OF MPC & $4.12 E-04$ & $5.15 E-04$ & $1.40 E-09$ & $5.85 E-03$ & $6.23 E-02$ & $2.92 E-03$ & 5.86E-05 & $1.67 E-03$ \\
\hline
\end{tabular}

SUM OF FRACTIONS EQUALS 2.14E-01 
REGION: Sierra Madre Mill METSET : Casper Wyoming
COOE: MILDOS-AREA $(03 / 89)$

DAIA: IESIC2.DAT

IIME SIEP MUMBER 5, After 19.5 Yeors
PAGE 45

$04 / 18 / 89$

DURATION IH YRS IS... B.O

$3.7 \mathrm{M}$, OIST $=2.6 \mathrm{KM}, I \mathrm{RTYPE}=10$

4OCFRI9O ANNUAL DOSE COMMTMENTS COMPUTEO FOR IHIS LOCATION, MREH/YR

\begin{tabular}{|c|c|c|c|c|c|c|c|}
\hline AGE & PATHUAY & EFFECIIV & SOHE & AVG.LUHG & LIVER & KIDNEY & SRONCHI \\
\hline \multicolumn{8}{|l|}{........ } \\
\hline INFANT & INHAL. & $3.85 E=01$ & $1.11 E+02$ & $1.87 E+02$ & $3.85 E+01$ & $3.02 E+01$ & $0.00 E+00$ \\
\hline IHFANI & GROUND & $3.66 \mathrm{E}-01$ & $3.66 \mathrm{E}-01$ & $3.66 \mathrm{E}-01$ & $3.66 E-01$ & $3.665-01$ & $3.66 \mathrm{E}-01$ \\
\hline INFAKT & CLOO & $8.52 E-07$ & $8.52 E-07$ & B. $52 E-07$ & $8.52 E-07$ & $8.52 E-07$ & $8.52 E-07$ \\
\hline INFANT & VEG. ING & $0.00 E+00$ & $0.00 E+00$ & $0.00 E+00$ & $0.00 E+00$ & $0.00 E+00$ & $0.00 E+00$ \\
\hline INFAHT & MEAT ING & $0.00 \mathrm{E}+00$ & $0.00 E+00$ & $0.00 E+00$ & $0.00 E+00$ & $0.00 \mathrm{E}+00$ & $0.00 E+00$ \\
\hline INFAH I & MILK ING & $0.00 \mathrm{E}+00$ & $0.00 E+00$ & $0.00 \mathrm{E}+00$ & $0.00 E+00$ & $0.00 E+00$ & $0.00 E+00$ \\
\hline \multicolumn{8}{|c|}{ 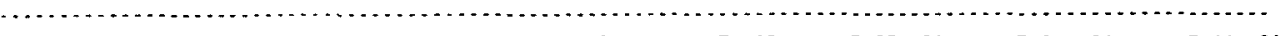 } \\
\hline INFANT & IOTALS & $3.89 \mathrm{E}+01$ & $1.11 E+02$ & $1.87 E+02$ & $3.89 E+01$ & $3.06 E+01$ & $3.66 \mathrm{E}-01$ \\
\hline AGE & PATHWAY & EFFECIIV & BONE & AVG.LUNG & LIVER & KIDHEY & BRONCHI \\
\hline \multicolumn{8}{|c|}{ (1) } \\
\hline CHILD & INHAL. & $1.70 E+09$ & $7.98 E+01$ & $8.69 E+01$ & $1.47 \mathrm{E}+01$ & $9.85 E+00$ & $0.00 E+00$ \\
\hline CHILD & GROUND & $3.66 \mathrm{E}-01$ & $3.66 \mathrm{E}-01$ & $3.66 \mathrm{E} \cdot 01$ & $3.66 \mathrm{E}-01$ & $3.66 \mathrm{E}-01$ & $3.66 \mathrm{E}-01$ \\
\hline CHILO & CLOUD & $8.52 E-07$ & $8.52 E-07$ & 8. $52 E-07$ & $8.52 E-G 7$ & $8.52 E-07$ & $8.52 E-07$ \\
\hline CHILD & VEL. ING & $1.65 E+01$ & $8.34 E+01$ & $7.22 E+01$ & $7.22 \mathrm{E}+01$ & $5.39 E+01$ & $0.00 E+00$ \\
\hline CHILD & MEAT INC & $2.45 E+00$ & $1.23 \mathrm{E}+01$ & $1.17 E+01$ & $1.17 E+01$ & $8.66 \mathrm{E}+00$ & $0.00 E+00$ \\
\hline CHILD & HILK ING & $0.00 E+00$ & $0.00 E+00$ & $0.00 E+00$ & $0.00 E+00$ & $0.00 E+00$ & $0.00 E+00$ \\
\hline \multicolumn{8}{|c|}{ 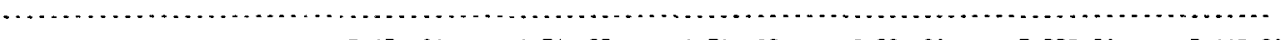 } \\
\hline$C H ! L D$ & TOTALS & $3.63 E+01$ & $1.76 E+02$ & $1.71 E+02$ & $9.90 E+01$ & $7.28 E+01$ & $3.66 E-01$ \\
\hline AGE & PATHHAY & EFFECTIV & BONE & AVG . LUNG & LIVER & KIONEY & BRONCHI \\
\hline TEENAGE & INHAL & $1.06 E+01$ & $9.46 \mathrm{E}+01$ & $4.50 \mathrm{E}+01$ & $6.64 E+00$ & $5.10 E+00$ & $0.00 \mathrm{E}+00$ \\
\hline TEENAGE & GROUNO & $3.66 E-01$ & $3.66 \mathrm{E}-01$ & $3.66 \mathrm{E}-01$ & $3.68 \mathrm{E}-01$ & $3.66 E-01$ & $3.66 \mathrm{E}-01$ \\
\hline TEENAGE & CLOUD & $8.52 E-07$ & $8.52 E-07$ & 8.52E-07 & $8.52 E-07$ & $8.52 E-07$ & 8. $52 \mathrm{E}-07$ \\
\hline TEEHAGE & VEG. ING & $2.71 E+01$ & $4.44 E+02$ & $6.44 E+01$ & $0.44 E+01$ & $5.49 E+01$ & $0.00 E+00$ \\
\hline TEENAGE & MEAT ING & $3.90 \mathrm{E}+00$ & $6.38 E+01$ & $1.02 E+01$ & $1.02 E+01$ & $8.62 E+00$ & $0.00 E+00$ \\
\hline TEENAGE & HILK ING & $0.00 E+00$ & $0.00 E+00$ & $0.00 E+00$ & $0.00 E+00$ & $0.00 E+00$ & $0.00 \mathrm{E}+00$ \\
\hline \multicolumn{8}{|c|}{ 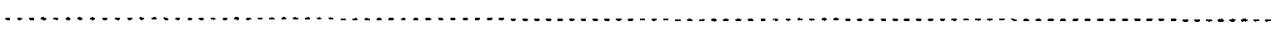 } \\
\hline TEENASE & TOTALS & 4. $19 E+01$ & $6.03 E+02$ & $1.20 E+02$ & 8. $16 E+01$ & $6.90 \mathrm{E}+01$ & $3.66 \mathrm{E}-01$ \\
\hline AGE & PATHWAY & EFFECTIV & BONE & AVG . LUNG & LIVER & KIDHEY & BRONCHI \\
\hline AOULT & INHAL. & 9. $15 E+00$ & $8.33 E+01$ & $3.72 E+01$ & $5.08 E+00$ & $3.63 E+00$ & $0.00 E+00$ \\
\hline ADUL T & GROUHD & $3.66 \mathrm{E} \cdot 01$ & $3.66 E-01$ & $3.66 \mathrm{E}-01$ & $3.66 E-01$ & $3.66 E-01$ & $3.66 E-01$ \\
\hline ADULT & CLOUD & B. 52E- 07 & $8.52 E-07$ & $8.52 E-07$ & $8.52 E-07$ & $8.52 E-07$ & 8.52E-07 \\
\hline ADULT & VEG. ING & $1.54 E+01$ & $1.88 \mathrm{E}+02$ & $4.20 E+01$ & $4.20 E+01$ & $3.50 \mathrm{E}+01$ & $0.00 E+00$ \\
\hline ADULT & HEAI ING & $2.84 \mathrm{E}+00$ & $3.51 E+01$ & $8.46 E+00$ & $8.66 E+00$ & $6.97 \mathrm{E}+00$ & $0.00 \mathrm{E}+00$ \\
\hline ADULT & MICK ING & $0.00 E+00$ & $0.00 E+00$ & $0.00 E+00$ & $0.00 E+00$ & $0.00 \mathrm{E}+00$ & $0.00 \mathrm{E}+00$ \\
\hline ADULT & TOTALS & $2.78 \mathrm{BE}+01$ & $3.07 E+02$ & $8.80 E+01$ & $5.59 E+01$ & $4.59 E+01$ & $3.66 E-01$ \\
\hline
\end{tabular}


REgION: Sierra Madre Mill MEISET : Casper Hyaming

NUMBER 3 MAME $=$ Grazing $E$
COOE: MILDOS-AREA (03/89)

DATA: TESTC2.OAT

TIME STEP HLMBER 5, After 19.5 Years
PAGE 46

$04 / 18 / 89$

DURATLON IN YRS IS... B.D

$X=2.6 K H, Y=0.0 K M, 2=3.7 \mathrm{M}, \mathrm{DISI}=2.6 \mathrm{KM}, I R T Y P E=10$

TOTAL AMHUAL DOSE COMMITMENTS COMPUTED FOR THIS LOCATION, MREM/YR

\begin{tabular}{|c|c|c|c|c|c|c|c|}
\hline AGE & PATHUAY & EFFECTIV & ВОНЕ & AVG.LUNG & LIVER & XIDNEY & BRONCH! \\
\hline & 80 & & & 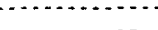 & & & -0 \\
\hline INFANT & INHAL. & $7.23 \mathrm{E}+01$ & $1.11 E+02$ & $1.87 E+02$ & $3.86 \mathrm{E}+01$ & $3.03 \mathrm{E}+01$ & $5.63 \mathrm{E}+02$ \\
\hline INFANT & GROUND & $1.87 E+01$ & $1.87 E+01$ & $1.87 E+01$ & $1.87 \mathrm{E}+01$ & $1.87 E+01$ & $1.87 E+01$ \\
\hline IMFAMT & CLOND & $4.23 E-01$ & $4.23 \mathrm{E}-01$ & $4.23 \mathrm{E}-01$ & $4.23 E-01$ & $4.23 E-01$ & $4.23 E-01$ \\
\hline IHFAHT & VEG. ING ${ }^{-}$ & $0.00 \mathrm{E}+00$ & $0.00 E+00$ & $0.00 E+00$ & $0.00 \mathrm{E}+00$ & $0.00 \mathrm{E}+00$ & $0.00 E+00$ \\
\hline IHFANT & MEAT ING & $0.00 E+00$ & $0.00 E+00$ & $0.00 \mathrm{E}+00$ & $0.00 E+0 C$ & $0.00 \mathrm{E}+00$ & $0.00 E+00$ \\
\hline INFANT & MILK ING & $0.00 E+00$ & $0.00 E+00$ & $0.00 E+00$ & $0.00 E+00$ & $0.00 E+00$ & $0.00 E+00$ \\
\hline \multicolumn{8}{|l|}{, } \\
\hline INFANT & TOTALS & $9.14 E+01$ & $1.30 E+02$ & $2.06 E+02$ & $5.77 \mathrm{E}+01$ & $4.93 E+01$ & $5.82 E+02$ \\
\hline AGE & PATHUAY & EFFECTIV & 80NE & AVG. LUNG & LIVER & KIDHEY & BRONCHI \\
\hline \multicolumn{8}{|c|}{ (1, } \\
\hline CHILD & INHAL. & $5.08 E+01$ & $7.98 E+01$ & $8.69 E+01$ & $1.48 E+01$ & $9.86 \mathrm{E}+00$ & $5.63 E+02$ \\
\hline CHILO & GROUND & $1.87 E+01$ & $1.87 E+01$ & $1.87 E+01$ & $1.87 E+01$ & $1.87 \mathrm{E}+01$ & $1.87 E+01$ \\
\hline CHILD & CLOUD & $4.23 E-01$ & $4.23 E-01$ & $4.23 E-91$ & $4.23 E-01$ & $4.23 E-01$ & $4.23 E \cdot 01$ \\
\hline CHILO & VEG. ING & $1.65 \mathrm{E}+01$ & $8.34 E+01$ & $7.23 E+01$ & $7.23 E+01$ & $5.40 E+01$ & $0.00 E+00$ \\
\hline CHILD & MEAT ING & $2.45 \mathrm{E}+00$ & $1.23 E+01$ & $1.17 E+01$ & $1.17 E+01$ & B. $66 \mathrm{E}+00$ & $0.00 E+00$ \\
\hline CHILO & MILK ING & $0.00 \mathrm{E}+00$ & $0.00 E+10$ & $0.00 E+00$ & $0.00 E+00$ & $0.00 E+00$ & $0.00 \mathrm{E}+00$ \\
\hline \multicolumn{8}{|c|}{$\begin{array}{l}n_{1} \\
n_{1}\end{array}$} \\
\hline CHILD & TOTALS & $8.88 E+01$ & $1.95 \mathrm{E}+02$ & $1.90 \mathrm{E}+02$ & $1.18 E+02$ & $9.16 E+01$ & $5.82 E+02$ \\
\hline AGE & PATHWAY & EFFECTIV & BONE & AVG. LUNG & LIVER & KIONEY & BRONCHI \\
\hline \multicolumn{8}{|c|}{ 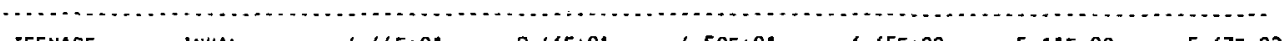 } \\
\hline ;EENAGE & INHAL. & $4.44 E+01$ & $9.46 E+01$ & $4.50 E+01$ & $6.65 \mathrm{E}+00$ & $5.11 E+00$ & $5.63 E+02$ \\
\hline TEENAGE & GROUMD & $1.87 E+01$ & $1.87 \mathrm{E}+01$ & $1.87 E+01$ & $1.87 E+01$ & $1.87 E+01$ & $1.87 E+01$ \\
\hline TEENAGE & CLOUD & $4.23 E-01$ & $4.23 \mathrm{E}-01$ & $4.23 E-01$ & $4.23 E-01$ & $4.23 E-01$ & $4.23 E \cdot 01$ \\
\hline TEENACE & VEG. ING & $2.71 E+01$ & $4.44 E+02$ & $6.44 E+01$ & $6.44 E+01$ & $5.49 E+01$ & $0.00 E+00$ \\
\hline TEEMAGE & HEAT ING & $3.90 \mathrm{E}+00$ & $6.39 E+01$ & $1.02 E+01$ & $1.02 \mathrm{E}+01$ & $8.62 E+00$ & $0.00 E+00$ \\
\hline TEENAGE & MILK ING & $0.00 E+00$ & $0.00 E+00$ & $0.00 E+00$ & $0.00 E+00$ & $0.00 \mathrm{E}+00$ & $0.00 E+00$ \\
\hline \multicolumn{8}{|c|}{ 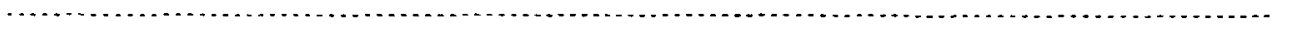 } \\
\hline TEENAGE & IOTALS & $9.44 E+01$ & $6.22 E+02$ & $1.39 E+02$ & $1.00 E+02$ & $8.78 E+01$ & $5.82 E+02$ \\
\hline AGE & PATHHAY & EFFECTIV & BONE & AVG.LUMG & LIVER & KIDHEY & 8RONCH! \\
\hline ADULT & I HHAL. & $4.30 E+01$ & $8.33 E+01$ & $3.72 E+01$ & $5.10 E+00$ & $3.63 E+00$ & $5.63 E+02$ \\
\hline ADULT & GROUND & $1.87 E+01$ & $1.87 E+01$ & $1.87 E+01$ & $1.87 E+01$ & $1.87 \mathrm{E}+01$ & $1.87 E+01$ \\
\hline ADULT & CLOUD & $4.23 E-01$ & $4.23 E-01$ & $4.23 E-01$ & $4.23 E-01$ & $4.23 E-01$ & 4.23E-01 \\
\hline ADULT & VEG. ING & $1.54 \mathrm{E}+01$ & $1.88 \mathrm{E}+02$ & $4.20 \mathrm{E}+01$ & $4.20 E+01$ & $3.50 E+01$ & $0.00 E+00$ \\
\hline ADULT & MEAI ING & $2.84 E+00$ & $3.51 E+01$ & $8.46 E+00$ & $8.46 E+00$ & $6.97 E+00$ & $0.00 E+00$ \\
\hline ADULT & MILK ING & $0.00 E+00$ & $0.00 E+00$ & $0.00 E+00$ & $0.00 E+00$ & $0.00 E+00$ & $0.00 E+00$ \\
\hline ADUL T & IOTALS & $8.03 E+01$ & $3.26 E+02$ & $1.07 E+02$ & $7.46 E+01$ & $6.47 E+01$ & $5.82 E+02$ \\
\hline
\end{tabular}




\section{DISTRIBUTION FOR ANL/ES-161}

\section{Internal}

$\begin{array}{ll}\text { N. Beskid } & \text { K.J. Hong } \\ \text { C. Boggs } & \text { L.D. Jensen } \\ \text { L.E. Boing } & \text { M.J. Jusko } \\ \text { S.Y. Chen (120) } & \text { K.S. Macal (5) } \\ \text { J. Devgun } & \text { B.J. Micklich } \\ \text { A.J. Dvorak } & \text { G.D. Mosho } \\ \text { E.E. Corup (2) } & \text { J.M. Peterson } \\ \text { L.J. Habegger } & \text { M.J. Robinet }\end{array}$

T.G. Surles

C. Yu

A.J. Zielen

ANL Contract Copy

ANL Libraries

ANL Patent Department

ANL Technical Publications

Services (3)

\section{External}

U.S. Department of Energy Office of Scientific and Technical Information (12) Manager, U.S. Department of Energy, Chicago Operations Office

V. Adams, U.S. Department of Energy, Oak Ridge, Tenn.

A.J. Adduci, U.S. Department of Energy, Oakland, Calif.

H.W. Arrowsmith, Scientific Ecology Group, Inc., Oak Ridge, Tenn.

R. Atkin, U.S. Department of Energy, Oak Ridge, Tenn.

T. Aud, Babcock \& Wilcox, Lynchburg, Va.

J.C. Baker, Jacobs Engineering Group, Inc., Pasadena, Calif.

E.J. Bentz, Jr., E.J. Bentz \& Associates, Inc., Springfield, Va.

J. Berger, Oak Ridge Associated Universities, Oak Ridge, Tenn.

H. Brandon, Baker/TSA Inc., Coraopolis, $\mathrm{Pa}$.

T. Brazley, U.S. Department of Energy, Germantown, Md.

H. Burkholder, Pacific Northwest Laboratory, Richland, Wash.

T.W. Burwinkle, Oak Ridge National Laboratory, Oak Ridge, Tenn.

M. Butler, National Energy Software Center, Argonne, I11. (10)

C. Collantes, U.S. Department of Energy, Richland, Wash.

W. Cottrell, Oak Ridge National Laboratory, Oak Ridge, Tenn.

F.P. Crimi, General Electric Co., Shippingport, Pa.

J.C. Dehmel, Dehmel, Inc., Larchmont, N.Y.

W.F. Dennison, Rockwell International Corp., Canoga Park, Calif.

K.F. Eckerman, Oak Ridge National Laboratory, Oak Ridge, Tenn.

R. Eckhart, University of Cincinnati, Cincinnati, Ohio

K. Eger, General Electric Co., Shippingport, Pa.

J.P. Englert, Dames \& Moore, Orchard Park, N.Y.

T. Erargos, U.S. Department of Energy, Germantown, Md.

J.R. Frazier, International Technologies, Oak Ridge, Tenn.

R. Freeberg, U.S. Department of Energy, Richland, Wash.

R. Garde, Los Alamos National Laboratory, Los Alamos, N.M.

R. Cardewing, Westinghouse Materials Company of Ohio, Cincinnati

J.H. Cibbons, Office of Technology Assessment, U.S. Congress

T.L. Gilbert, Chicago Center for Religion and Science, Chicago, Ill. 
G.N. Gnugnoli, U.S. Nuclear Regulatory Commission, Washington, D.C. (2)

M. Conzaiez, Lawrence Livermore National Laboratory, Livermore, Calif.

D. Coranson, U.S. Department of Energy, Richland, Wash.

R.J. Crandfield, U.S. Department of Energy, Miamisburg, Ohio

S. Green, Jacobs Engineering Group, Inc., St. Charles, Mo.

M. Haas, ENSA, Inc., Buffalo, N.Y.

W.R. Hansen, Los Alamos National Laboracory, Los Alamos, N.M.

J. Healey, Los Alamos National Laboratory, Los Alamos, N.M.

R. Hlavacek, M.K. Eergusen Company, St. Charles, Mo.

M. Hughes, Westinghouse Hanford Corporation, Richland, Wash.

N.E. Irizarry, Center for Energy and Environment Research, Mayaguez, P.R.

D.W. James, James LCE Associates, Minneapolis, Minn.

R. Jeager, EG\&G Mound Applied Technologies, Miamisburg, Ohio

W.A. Jester, Pennsylvania State University, University Park

N.R. Johnson, Thermo Analytical, Inc., Albuquerque, N.M.

M.R. Jugan, U.S. Department of Energy, Oak Ridge, Tenn.

P. Kalb, Brookhaven National Laboratory, Upton, N.Y.

K. Karp, UN: Geotech, Grand Junction, Colo.

D.E. Kash, University of Oklahoma, Norman

W.E. Kennedy, Jr., Battelle Pacific Northwest Laboratory, Richland, Wash.

A. Kluk, U.S. Department of Energy, Germantown, Md.

D. Kocher, Oak Ridge National Laboratory, Oak Ridge, Tenn.

D. Kozlowski, U.S. Department of Energy, Germantown, Md.

K. Lawver, U.S. Department of Energy, St. Charles, Mo.

C. Lee, Applied Physics, Albuquerque, N.M.

B. Lewis, Northwestern University, Evanston, Ill.

G. Linsley, International Atomic Energy Agency, Vienna, Austria

D. MacFarlane, Los Alamos National Laboratory, Los Alamos, N.M.

C.E. Maggart, U.S. Department of Energy, Idaho Falls, Idaho

R. Marri, UNC Geotech, Grand Junction, Colo.

S. Marutzky, UNC Geotech, Grand Junction, Colo.

C. Massey, Oak Ridge National Laboratory, Oak Ridge, Tenn.

D. Mauer, Colorado Department of Health, Denver, Colo.

R. Meservey, EG\&G Idaho, Inc., Idaho Falls, Idaho

M. Miller, Albuquerque, N.M.

B. Musgrave, Lawrence Livermore National Laboratory, Livermore, Calif.

S. Nair, Bechtel National, Inc., Oak Ridge, Tenn.

B.A. Napier, Battelle Pacific Northwest Laboratories, Richland, Wash.

J. Neff, U.S. Department of Energy, Columbus, Ohio

C. Nelson, U.S. Environmental Protection Agency, Washington, D.C.

R.R. Nelson, U.S. Department of Energy, St. Charles, Mo.

R.A. Nelson, Jacobs Engineering Group, Inc., St. Charles, Mo.

S. Neuder, U.S. Nuclear Regulatory Commission, Washingron, D.C.

D. Padilla, U.S. Department of Energy, Los Alamos, N.M.

P.L. Piciuio, Ecology and Environment, Inc., Lancaster, N.Y.

J.W. Ray, Baztelle Columbus Laboratories, Columbus, Ohio

C.J. Roberts, Dames \& Moore, West Valley, N.Y.

R.C. Robertson, Bechtel National, Inc, Dak Ridge, Tenn. 
J.C. Rodgers, Los Alamos National Laboratory, Los Alamos, N.M. J. Russell, U.S. Environmental Protection Agency, Washington, D.C.

J.J. Schreiber, U.S. Department of Energy, Shippingport, Pa.

M. Scott, Louisiana State University, Baton Rouge, La.

V. Scovill, U.S. Nuclear Regulatory Commission Region IV, Denver, Colo.

D. Seepo, U.S. Department of Energy, Schenectady, N.Y.

E. Shum, U.S. Nuclear Regulatory Commission, Washington, D.C.

L. Sims, Bechtel National, Inc., Oak Ridge, Tenn.

A.C. Smith, Ecotek, Inc., Erwin, Tenn.

¿. Soholt, Los Alamos National Laboratory, Los Alamos, N.M.

J.K. Soldat, Battelle Pacific Northwest Laboratories, Richland, Wash.

A. Soong, U.S. Nuclear Regulatory Commission, Washington, D.C.

K.T. Stafford, Ro:kwell International Corp., Canoga Park, Calif.

M. Steinhouse, Battelle Columbus Laboratories, Columbus, Ohio

D. Swager, University of Cincinnati, Cincinnati, Ohio

J. Tarcza, Westinghouse - Hanford, Richland, Wash.

B. Thomas, International Technologies, Oak Ridge, Tenn.

J.C. Tseng, U.S. Department of Energy, Washington, D.C.

J. Turi, U.S. Department of Energy, Germantown, Md.

B. Walker, U.S. Department of Energy, Oak Ridge, Tenn.

A. Wallo III, U.S. Department of Energy, Germantown, Md. (15)

J.H.C Wang, Atomic Energy Council, Taipei, Taiwan

J. Williams, Bechtel National, Inc., Oak Ridge, Tenn.

D. Williamson, U.S. Department of Energy, Grand Junction, Colo.

B. Wissink, Health Physics Service, St. Paul, Minn.

D.E. Wood, Westinghouse Hanford Company, Richland, Wash.

Y.C. Yuan, Dames \& Moore, West Valley, N.Y. (10) 